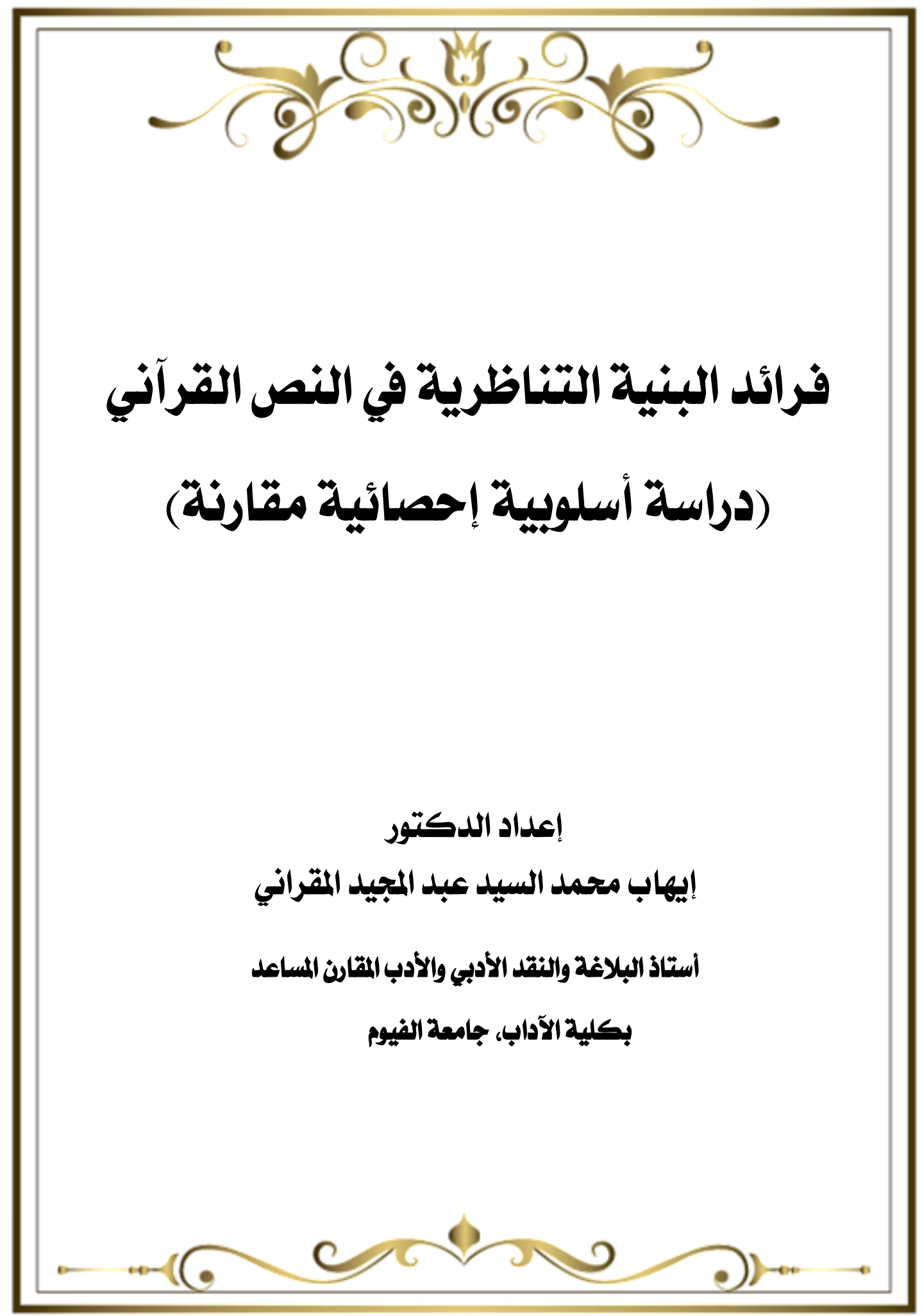


المجلد الثامن والثلاثون إصدار يونيو.r.r.

गิे

(ी)

مجلدئ

كلية

الإسلامية

والعربية

-

oxpe 


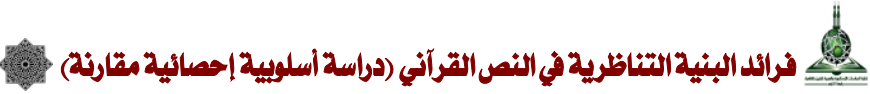
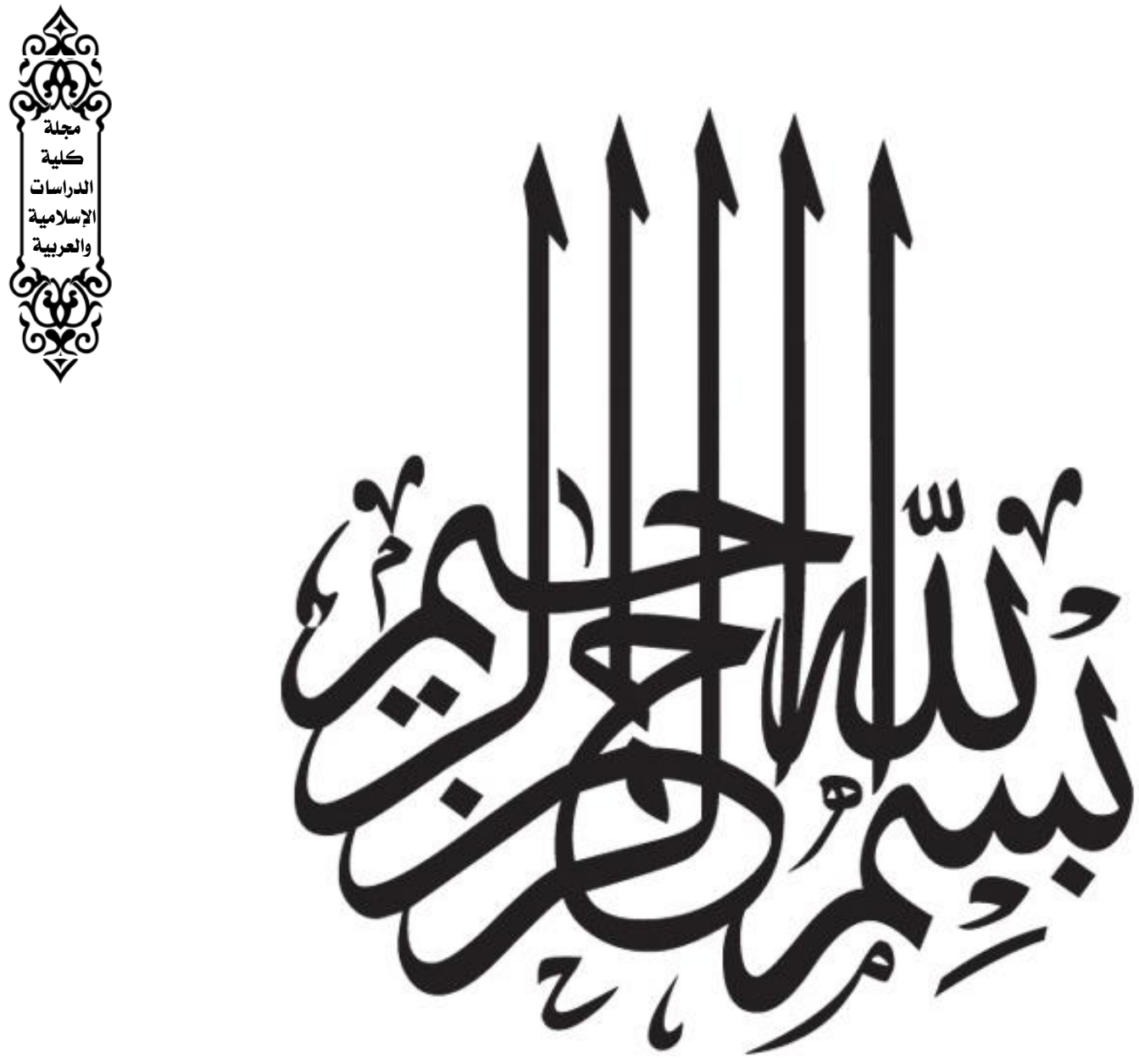
المجلد الثامن والثلاثون إصدار يونيو.r.r.

गิे

(ी)

مجلدئ

كلية

الإسلامية

والعربية

(2)

oxpe 


\section{فرائل البنية التناظرية في النص القرآني (دراسة أسلوبية إحصائية مقارنة)}

$$
\text { إيهاب محمد السيد عبد الجيد المقراني }
$$

تخصص البلاغة والنقد الأدبي والأدب المقارن بكلية الآداب، جامعة الفيوم

تقوم الدراسـة على تطبيق نظرية (روبرت لوث) في دراسـته الثـعر العبري المقدس في العهد

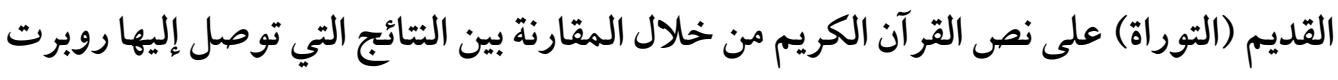

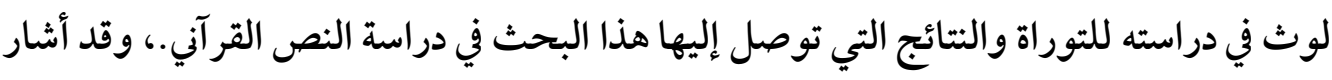
روبرت لوث إلى قيام الشعر العبري في النص التوراتي على بنية تناطرية واضحة. قسَّم روبرت لوث البنية التناظرية في التوراة إلى ثلاثة مظاهر:

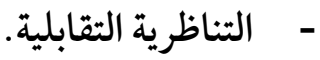

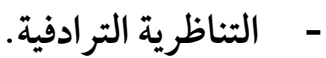

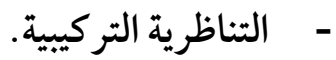

وفي ضوء نظرية روبرت لوث تكونت هذه الدراسة من مقدمة وثلاثة مباحث وخاتمة.

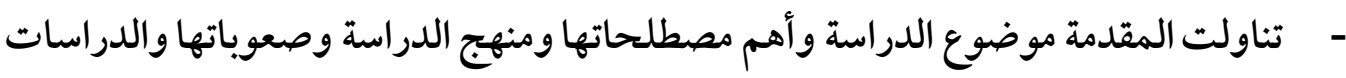

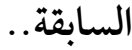

- - - مناول المبحث الأول قضية المقارنة بين القرآن والتوراة في البنية التناظرية التقابلية. - - - مناول المبحث الثاني قضية المقارنة بين القرآن والتوراة في البنية التناظرية الترادفية. - - مناول المبحث الثالث قضية المقارنة بين القر آن والتوراة في التناظرية التركيبية. - - مناولت الخاتمة تلخيصا للبحث وأهم نتائجه . الكلمات المفتاحية: البنية - التوازي - القر آن الكريم - البلاغة القرآية - التوراة - الكتاب البهاب

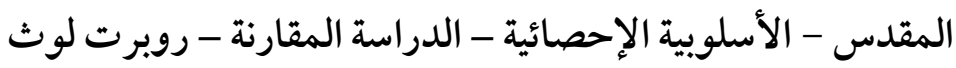




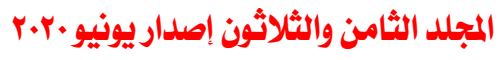

Aspects of Individuation in the Parallel Structure of the Qur'anic Text A Statistical and Stylistic Comparative Study

By: Ehab Mohammed Al- Sayed Abdul-Majeed Al-Magrani

Majored in Rhetoric, Literary Criticism and Comparative Literature

Faculty of Arts

Fayoum University

Email: emm06@fayoum.edu.eg

\section{Abstract}

This research considers applying Robert Lowth's theory, which he developed through studying the sacred Hebrew poetry in the Old Testament (Torah), on the Qur'anic text by comparing the results reached by Lowth in his study of the Torah and those reached by the researcher in his study of the Qur'anic text. Robert Lowth had found out that the Hebrew poetry in the Torah relied on a clear parallel structure. Therefore, Lowth identified three main forms of parallelism in the structure of the of the Torah: the antithetic, the synonymous and the synthetic. Accordingly, this research consists of an introduction, three chapters and a conclusion. The introduction highlights the topic of the research, the most important terminology, the approach of the research, the hardships and the previous studies. The first chapter focuses light on the issue of the parallel antithetic structure in comparison between the Qur'an and Torah. Whereas the second chapter compares the synonymous parallel structure in both the Qur'an and Torah. As for the third chapter, it discusses the issue of the synthetic parallel structure in comparison between the Qur'an and Torah. Finally, the conclusion sums up the main points of the research and the most outstanding findings.

Key words: structure, parallelism, the Holy Qur'an, Qur'anic rhetoric, Torah, the Bible, statistical stylistics, comparative study, Robert Lowth 


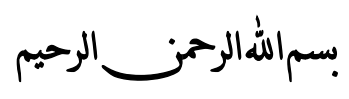

توطئة:

تتفق كثيرٌ من النصوص الدينية في المجتمع البشري على استخدامِ عدٍٍ من الملامح الأسلوبية، يطلق عليها الدارسون أحيانا سمات التوازي أو المزاوجة، أو سمات الأسلوب السيمتري المتوازن(')، وهي الطريقة التي تمثل "التراتيل المعهودة في الشعائر الدينية"(؟) وتَتَجسَّد تجلياتها في الثقافة العربية فيما يسميه البلاغيون العرب حسن التقسيم أو التناسب أو التكرار أو اللف والنشر إلى آخر السلسلة الطويلة من فنون البديع العربي وخصوصا البديع اللفظي (ז)، وتتناول الدراسة هذه الظاهرة - التي حظيت بقدر هـائل من الدرس والتمحيص قديما

|(1) ينظر المعجم العلمي للمعتقدات الدينية، إعداد مجموعة من علماء مقارنة الأديان، تعريب وتحرير سعد

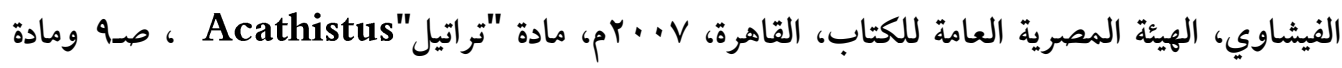
"ترنيمة" Sticheron ، صده .7، وينظر القس صموئيل مشرقي (رئيس المجمع العام لكنائس الله الخمسينية)، مصادر الكتاب المقدس بحث في أصول الكتاب وبيان حقيقة مصادره، الناشر: الكنيسة المركزية

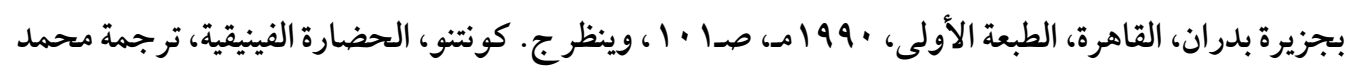
عبد الهادي شعيرة، مر اجعة د. طه حسين، الهيئة المصرية العامة للكتاب، 99 | |م، صـ \& Y I .

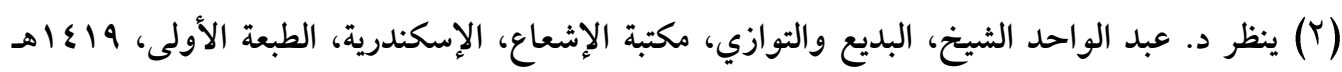
. $1 \cdot 19$. 1999

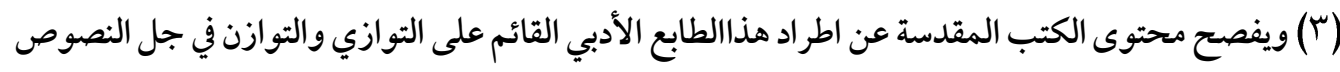

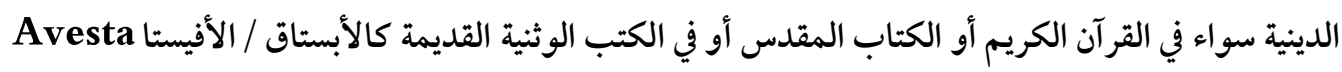
بما تنطوي عليه من ترانيم زرادشت (الكتاب المقدس في الوثنية الفارسية القديمة) . ينظر ترانيم زرادشت من كتاب الأفستا المقدس، ترجمة وتقديم فيليب عطية (وهي الترجمة العربية التي نقلها

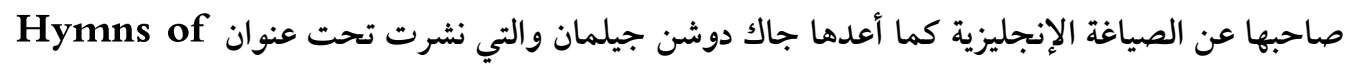
Zarathustra 
وحديثا - من منظور مغاير هو منظور المقارنة بين القرآن الكريم والنص التوراتي من خلال دراسة “روبرت لوث" (Robert Lowth) للتوازي في أسفار العهد القديم في كتابه: "محاضرات في الشعر العبري المقدس" ( Lecture on the sacred poetry of

(') (Hebrews

، أو أدي جر انث (الكتاب المقدس لدى السيخ) أو كتاب الفيدا، أو الشروتي، أو الإسميراتي/ السيمريتي (الشعر الملحمي الهندي المقدس)، أو كتاب تاتفارثا سوترا (الكتاب المقدس في الديانة الجاينية في الصين)، أو غيرها من الكتب المقدسة..

- Monier Williams ،Sanskrit English Dictionary ،Oxford University Press ،Entry for Sutra ،page 1241.

- M Winternitz ،A History of Indian Literature ،Motilal Banarsidass، Reprint 2010 ، Volume 1 ،page 249.

وقد سجّّل معالمَ هذه الظاهرة د. عبد الواحد الشيخ، حيث أشار إلى ذيعان أسلوب التوازي في آثار الشرق القديم كما هي الحال في النصوص الأوجاريتية والبرديات المصرية القديمة والسومرية والبابلية والآشورية والعربية،

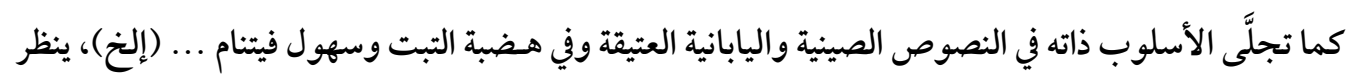

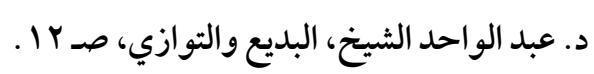

وقد برزت هذه الظاهرة - أيضا - من خلال الموروث الشفاهي لكُهَّانِ الوثنية في الجزيرة العربية في العصر

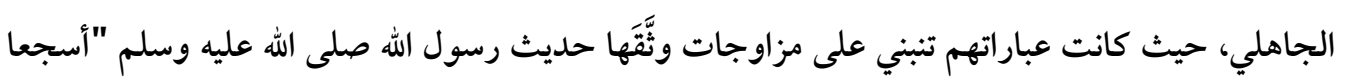

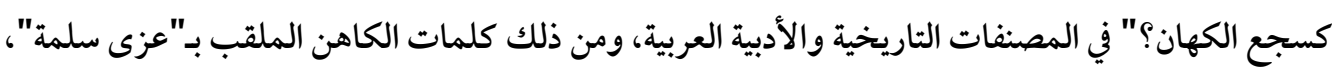

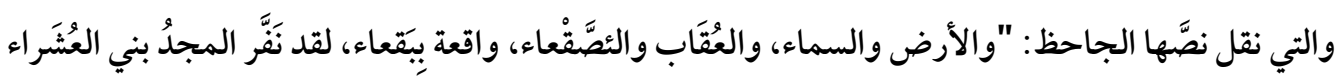

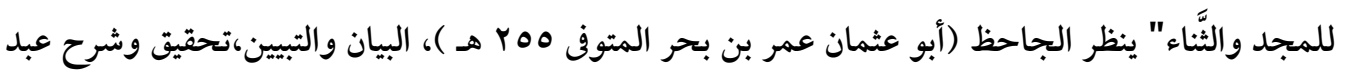

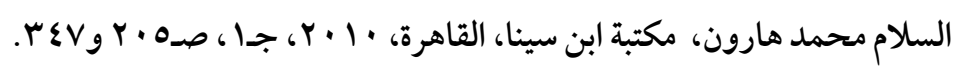

(1) Robert Lowth, Lecture on the sacred poetry of Hebrews, London, printed for Thomas Tegg \& Son, Cheapside, Tegg, Wise \& Tegg, Dublin, Griffin \& Co. Glasgow, and James \& Samuel Augustus Tegg, Sydney, Australia, The Third Edition. 


\section{9)}

وتسعى الدراسة إلى الكثف عن نقطة الاختلاف بين التوازي التوراتي والتناظرية القر آنية

من خلال تحديد المستوى التوازني الذي توقفت عنده ظواهر التوازي في العهد القديم عند روبرت لوث وهو مستوى الكلمة والجملة، ثم المستويات الأرحب التي تجلَّت من خلالها التناظرية القرآنية التي لم تقف عند حدود الكلمة والجملة وحسب، بل تجاوزت ذلك إلى مستوى السورة، ثم مستوى مجمل النص القرآني، وهو المستوى الذي ينطوي على الأنماط التكرارية القياسية المزعومة في كثير من الكتب المقدسة، التي تتجلَّى من خلال ما ذاع بين العوام من دلالات رقمية للكلمات المتقابلة أو المتر ادفة، والتي نُسِبَت للقر آن والتوراة على حد سواء، ومن ثم تسعى هذه الدراسة إلى أن تفصح عن إجابات علمية محكمة بضوابط المنهج الأسلوبي الإحصائي لأسئلة مشروعة ومتكررة حول ما ذاع حول هذه الدلالات الرقمية، حسما للجدل المستمر حول إثباتها أو نفيها، لتنتقل عبر هذه المنهجية الأسلوبية الإحصائية - ومن خلال ما تحتمه فروضها وإجراءاتها - من طرح هذه التساؤلات الأولية إلى طرح تساؤلات أخرى حول مصادر هذه النصوص ونسبتها إلى منتسبيها. وتقف هذه الدراسة وفق هذه المنهجية بين مستويين

$$
\text { للدرس الأسلوبي الإحصائي: }
$$

المستوى الأول: المعني بتحديد السمة العامة لأسلوب طبقة، أو أسلوب مهنة من المهن، أو ثقافة من الثقافات، وهو ما ينطبق على الأسلوب الثعائري المؤسس على التوازي الذي تتسم به الثقافة الدينية على وجه العموم عبر اختلاف تجلياتها، وهو المستوى العام الذي يهتم به المشتغلون بعلم اللسانيات الاجتماعية Socialingustics . . . المستوى الثاني: مستوى الفروق الفردية بين الأساليب التي تنتمي لفئة عامة، أو طبقة اجتماعية، أو مجتمع ثقافي محدد، وهو المستوى الذي يهتم به علم الأسلوب Stylistic (')، والذي بمقتضاه تُجلي الدراسة الأسلوبية الخصائص المميزة لنصٍ ديني بعينه عما سواه من ( (1) د. سعد عبد العزيز مصلوح، الأسلوب دراسة لغوية إخصائية، عالم الكتب، القاهرة، الطبعة الثالثة، Y 1 ـ اهـ

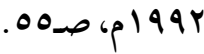




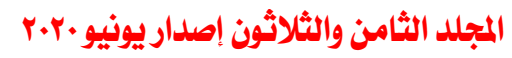

نصوص تشترك معه في كونها نصوصا دينية تعتمد أساليب التوازي والتناظر، وتختلف عنه في الخصائص الفنية التي تتجلَّى من خلالها هذه الأساليب..

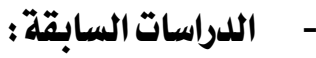

وقد سبق لعدٍٍ كبيرٍ من الدراسات القر آنية أن اشتغلت بتفصيل مظاهر التناظرية في آي

القر آن الكريم، لكن هذه الدراسات انحصرت في التجليات الجزئية للتناظرية القر آنية كما تبدَّت على مستوى الكلمة أو الجملة، ولم تتجاوز ذلك إلى دراسة التناظرية من خلال المنهج الأسلوبي الإحصائي على مستوى السورة أو على مستوى النص القرآني في مجمله، وفيما يلي مسرد بهذه الدراسات:

التوازي التركيبي في القرآن الكريم، عبد الله خليف خضير عبيد الحياني، رسالة ماجستير مخطوطة، إشراف د. هاني صبري ود. علي آل يونس، جامعة الموصل، هب\& اهـ -

$$
\cdot p^{r} \cdot \varepsilon
$$

توازي الضمائم في النسق القرآني، د. هاني صبري، مقال منشور في مجلة التربية والعلم،

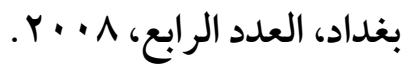

التوازي في القرآن الكريم دراسة في النظم الصوتي والتركيبي "الريع الأخير أنموذجا"، سهيلة زتوت، رسالة ماجستير مخطوطة، إشراف د. على زيتونة مسعود، الجزائر، جامعة

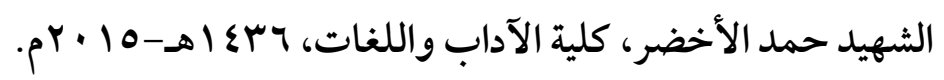

بلاغة التوازي في السور المدنية، العربي عبد الله، رسالة ماجستير مخطوطة، إشراف د.

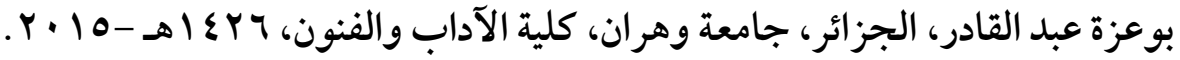
التوازي التركيبي الصرفي في القرآن الكريم دراسة في الأساليب اللغوية، إنصاف عبد الله

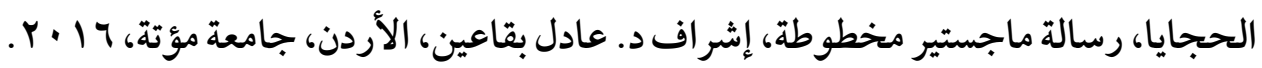
التوازي بين لغة القرآن الكريم والكتاب المقدس، أ.م.د عبد القادر جبار، مقال منشور

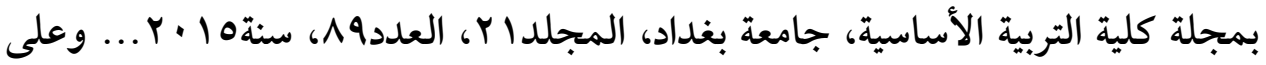


الرغم من أن هذه المقالة الأخيرة تبدو - من خلال عنو انها - أقرب الدراسات السابقة إلى موضوع هذا البحث، فإنها - وفق ما انطوى عليه متن الدراسة - قد خلت من أية مقارنة على مستوى النص بين التوازي في القرآن الكريم والكتاب المقدس، حيث توقفت عند عرض مفهوم التوازي في الدراسات النقدية والبلاغية العربية - من جانب - وهذا المفهوم بعينه في الدراسات النقدية الغربية - بوجه عام - والدراسات النقدية المتعلقة بالكتاب

المقدس - على وجه خاص - من جانب آخر - ، وعلى هذا فقد انقسمت هذه المقالة إلى

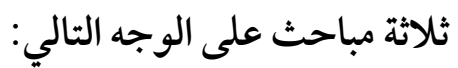

هـلال العسكري ورشيد الدين الوطواط والرازي والقزويني والعلوي والسيوطي والكفوي..

التوازي في المفهوم الغربي: وعرض فيه مفهوم التوازي في دراسات بلير وجيرار مانليه وبكنز

$$
\text { ورومان جاكبسون ويوري لوتمان. }
$$

- النص في القرآن الكريم: وتناول فيه علاقة النص القرآني بجنسي الشعر والثثر بين من نفى هذه العلاقة ومن زعم اقتراب النسق القر آني من نسق الثر، وساقت المقالة في هذا المساق المعالجة التطبيقية الوحيدة حين عقدت مقارنة بين ظاهرة التكرار في القرآن ومثيلتها في الشعر العربي من خلال عدد من سور القرآن الكريم وقصيدة وحيدة للمهلهل، وهكذا فقد

$$
\text { خلت المقالة من أي نص ينتمي إلى الكتاب المقدس... }
$$

وقد وقْتُّ أمام هذه الدراسات لكي أحدد نقطة البدء في دراستي هذه من خلال تجاوز القضايا التي تداولتها سعيا إلى وضع إطار علمي منهجي تختص به هذه الدراسة، ولا تشترك فيه

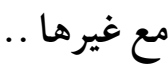


الفرائد Unrepeatables: والفرائد في اللغة هي الأشياء النادرة التي لا نظير لها ولا ند(')، ومن ثم فالمراد بها في هذه الدراسة الملامح الأسلوبية التي يتفرد بها النص القرآني دون غيره من النصوص الأدبية أو الدينية.

وهكذا استخدمت الدراسة لفظة الفرائد بمفهومها اللغوي دون المفهوم الاصطلاحي

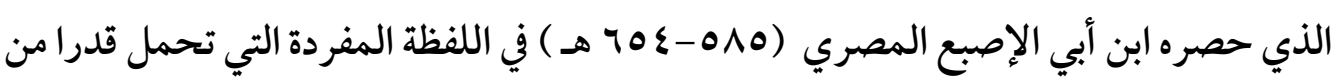
الندرة والتفرد لا يسمح أن يسد غيرها مسدها(Y)، وذلك لسببين: الأول: لأن المفهوم اللغوي لا يقف عند فرائد الألفاظ المفردة، بل يتسع ليشمل الفرائد

( (1) ينظر ابن منظور (أبو الفضل جمال الدين محمد بن مكرم بن علي الأنصاري الرويفعي الأفريقي المتوفى

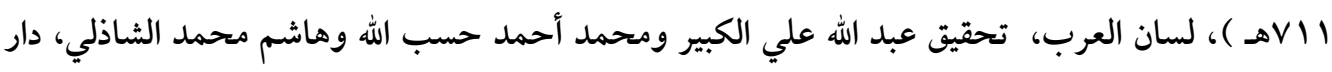

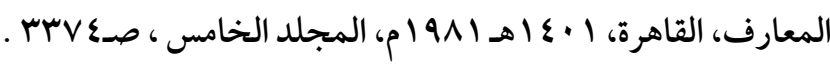

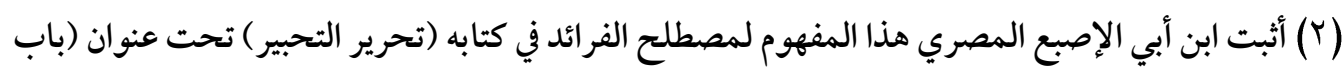

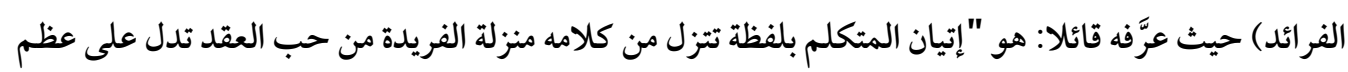
فصاحته وقوة عارضته وشدة عربيته حتى إن هذه اللفظة لو سقطت من الكلام لعز على الفصحاء غرامتها".

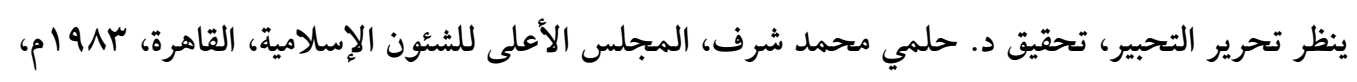

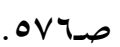
ثم تناول صفي الدين الحلّي (VVV - TV - O هـ ) المصطلح ذاته وفق مفهوم ابن أبي الإصبع في شرح الكافية البديعية حين خص بابا أطلق عليه اسم (الفرائد).

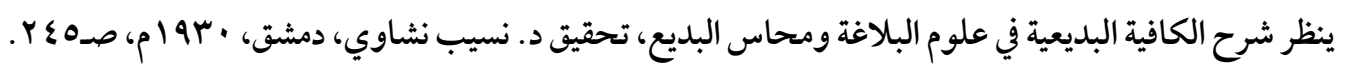

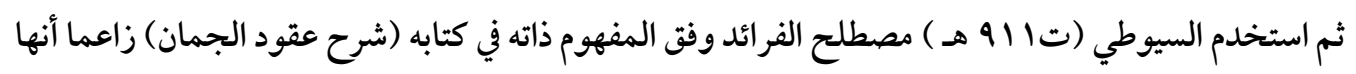

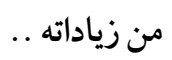
ينظر شرح عقود الجمان في علم المعاني والبيان، مطبعة ومكتبة مصطفى البابي الحلبي، القاهرة، 9ه9 (مب، صـ. 10 


\section{فرائل البنية التناظريح في النص القرآني (دراسة اسلوبية إحصائية مقارنة)}

بمفهومها العام الذي يشمل فر ائد التركيب وفر ائد البنية الكلية للنص، وهو ما ينقل المدلول من الحيّز المدرسي الضيق إلى المفهوم الفلسفي الأكثر عمقا ..

الثاني : لأن المفهوم اللغوي الواسع يتسق مع المفهوم العام لمصطلح البنية، الذي لا يقف عند المفردات والجزئيات، بل يشمل حاصل جمع العناصر المُشكلة للنص .. البنية : structure تعبر كلمة البنية عن مفهوم المجموع المؤلَّف من عناصر متماسكة، لا تحمل أيٌ منها قيمتها إلا من خلال اتساقها مع مجمل النص(')، أو كما يقول كلود ليفي شتراوس: "البنية نسق يتألف من عناصر يكون من شأن أي تحوُّل يعرض للواحد منها أن يُحْدِثَ تحولاً في بقية العناصر الأخرى"(r)، ومن ثم تجتهد هذه الدراسة - كما مرَّ - في تناول ظاهرة البنية التناظرية في القرآن الكريم، ليس من خلال الجزئيات (الكلمات والجمل) فقط، كما هي الحال في جل الدراسات التي تناولت التوازي في القرآن الكريم، ولكن من خلال البنية العامة للنص القرآني.

التناظرية Analog: وتعني بها هذه الدراسةُ قيامَ النص القرآني على المزاوجات الأسلوبية المتجسِّدة فيما يَصْطلح عليه شُرَّاح النص الكريم بتسمية "مثاني القر آن"، وهي نفسها

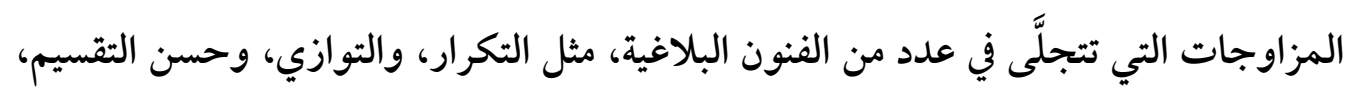
والطباق، والمقابلة .... (إلخ)... وهكذا فمصطلح التناظرية في هذه الدراسة يتر ادف مع مصطلح "المثاني" في التعبير القرآني كما يرادف مصطلحا أوربيا حديثا آخر هو "التوازي" Parallelism، وقد ورد مصطلح

( ) ينظر : جان بياجيه، البنيوية، ترجمة: عارف منيمنة وبشير أوبري، الطبعة الثالثة، بيروت، باريس، منشورات

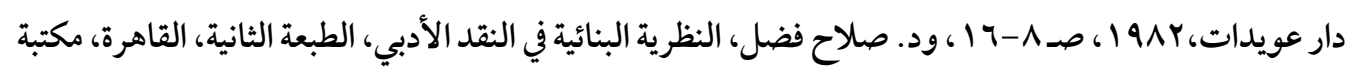

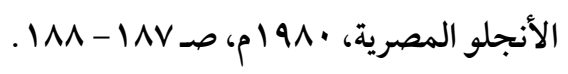

(Y) د. عز الدين المناصرة، علم الشعريات (قراءة مونتاجية في أدبية الأدب)، الطبعة الأولى، دار مجدلاوي،

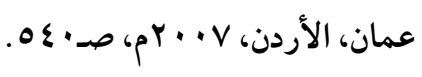


التوازي في الدراسات الغربية للنص التوراتي على يدي "روبرت لوث" Robert Lowth في دراسته المذكورة لظاهرة التقسيمات المتوازنة في نصوص التوراة من خلال كتابه محاضرات في الشعر العبري المقدس Lecture on the sacred poetry of Hebrews (') اتسعت دراسات التوازي على أيدي عدد من الدارسين الذين اقتفوا آثار الرائد الكبير "روبرت

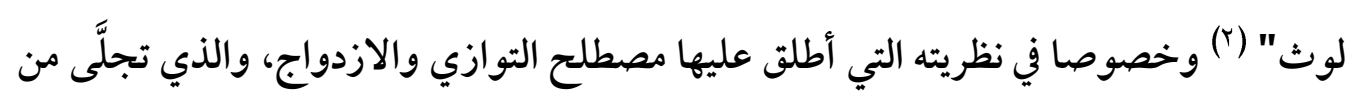
خلال ثلاثة مظاهر هي: - الازدواج أو التوازي الترادفي Synonymous pairs.

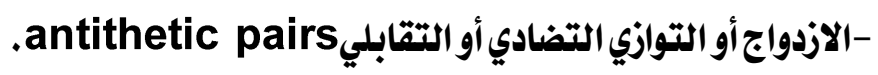

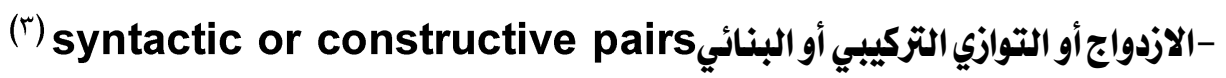

( ) و وهناك خطأ شائع لدى الدارسين مؤداه الاعتقاد بأن نشأة هذا المصطلح لدى “روبرت لوث" حدثت في دراسة

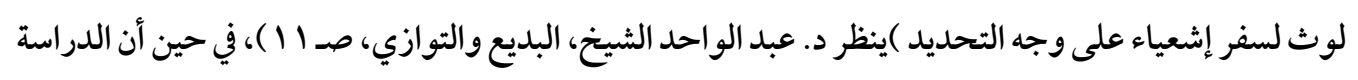

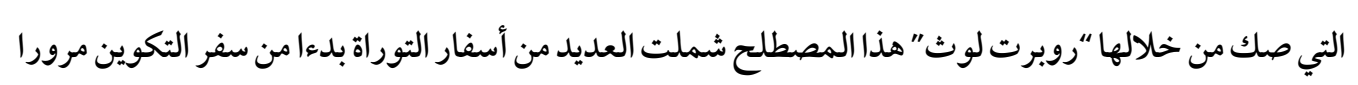

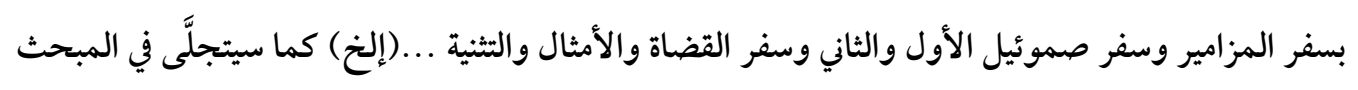

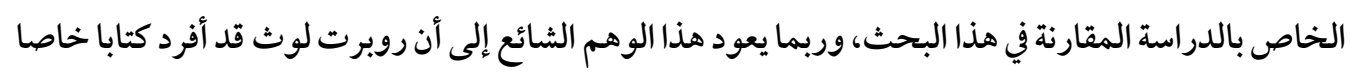

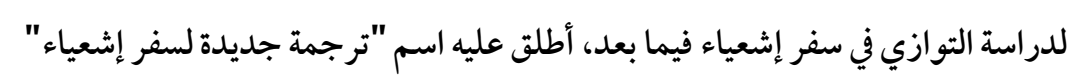

Robert Lowth, Isaiah: a New Translation with a Preliminary Dissertation, and Notes, Critical, Philosophical, and Explanatory, Boston: William Hillard, 14 Water Street, Cambridge: James Munroe and Company, 10th English Edition, 1834.

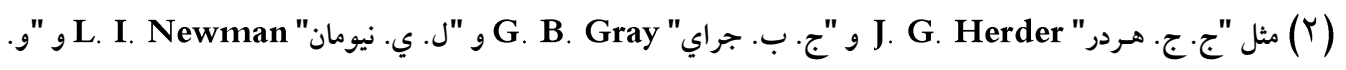

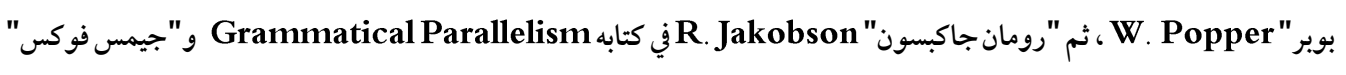
Parallelism في كتابه James Fox Roman Jakobson and the Comparative Study of (r) وقد كان لنظرية روبرت لوث تأثير هائل في التفكير النقدي الأوربي حيث مثَّلت رافدا رئيسا في التصورات

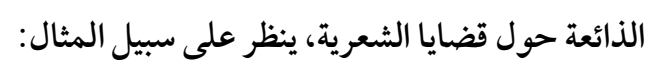


وقد حظيت هذه القسمة الثلاثية بوجه خاص و أفكار "روبرت لوث" حول الشعر العبري

على وجه العموم باحتفاء هائل دفع عددا من الدارسين الأوربيين إلى رفع "لوث" إلى درجة الرجال الذين تبعث بهم العناية الإلهية كل حين من الدهر ليغيروا ثوابت الفكر ويبدلوا موازين الحضارة، ومن قبيل هذا ما أورده محقق كتابه ونصه: "في فترات مختلفة من تاريخ البشرية، تحفز العناية الإلهية الرجال المؤهلين لإحداث ثورة مكتملة في الفكر من خلال ما يمثله هـؤلاء الرجال من تفرّدٍ عقلي وتميّز واستقلال فكري يؤهلهم لكي يكونوا قادة الجنس البشري ورواده في تحقيق التحضر والتمدين، أولئك الذين يستحقون عن جدارة لقب نواب الله على الأرض، الذين يحكمون عالم العقل بحكم الله وإرادته، وإن من هـؤلاء السيد "روبرت وليام لوث" (1). وقبل "روبرت لوث" ورد مصطلح التوازي في الموروث العربي، و كان يضيق حينا ليعبر عن مفهوم السجع (r)، ويتسع أحيانا ليشمل جل مفاهيم المحسنات اللفظية(r)، ويتسع أكثر - في

- Jean Molino-Joélle ،Tamine، Introduction à l’analyse de la poésie، presses universitaires de France Paris 1982 ‘p. 211.

- D.Delas. J.Fill، Linguistique et poétique، langue et language، Larousse، Paris 1973 ، p.73.

- J.C.Coquet، Poetique et Linguistique، in Essais de sémiotique poétique، Larousse ، Paris 1972، p.28..

(1)Robert Lowth, Lectures on the sacred poetry of the Hebrews, (Translated by: G. Gregory), a New Edition with Notes by: Calvin E., Codman Press, Andover, United States, 1829, Intro, P III.

(Y) كما هو الشأن لدى أبي هـلال العسكري، ينظر الصناعتين في الكتابة والشعر، تحقيق علي محمد البجاوي

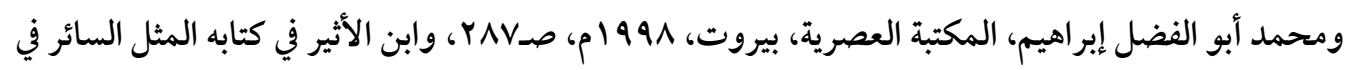
أدب الكاتب والشاعر، تحقيق د. أحمد الحوفي ود. بدوي طبانة، دار نهضة مصر، (د.ت).، صـهــ، والنويري

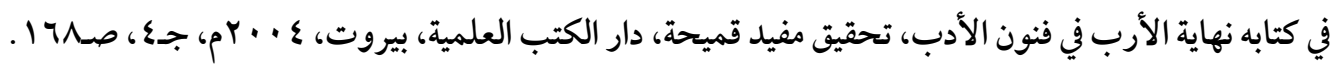
(Y) ينظر الفخر الرازي (الإمام محمد بن عمر بن الحسين المتوفى7 ·ج هـ)، نهاية الإيجاز في دراية الإعجاز،

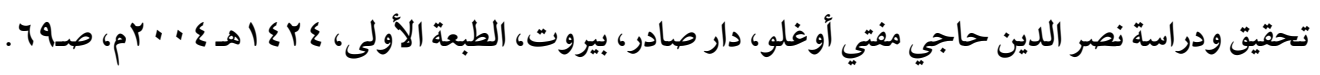


أحيان أخرى - ليشمل كل فنون البلاغة(')، وقد اتسع اهتمام الدارسين العرب بمفهوم “روبرت لوث" للتوازي، وتعددت الدراسات العربية التي طبقت هذا المفهوم في تحليل ظواهر القرآن الكريم والشعر العربي(؟)، ولكن لم تتجاوز هذه الدراسات العربية خطة “روبرت لوث" في الوقوف على مستوى الكلمات المتناظرة في الجملة، أو العبارات المتناظرة في الفقرة، دون النظر إلى مجمل النص، وهو ما تجتهد هذه الدراسة في تجاوزه ... وإذا كان مفهوم التوازي لدى روبرت لوث في الثقافة الأوروبية ومن قبله لدى البلاغيين العرب قد انحصر في العبارات والجمل دون النظر إلى الملامح التناظرية في مجمل النص، فإن هذا بعينه هو ما دفع هذه الدراسة إلى استبدال مصطلح التناظر بمصطلح التوازي الذي لا ينطبق محتواه الدلالي على ما تهدف إليه هذه الدراسة ..

النص Text: ويعني نسيجا من الكلمات التي يتسق بعضها مع بعض، لتشكل خيوطا تجمع عناصره المختلفة والمتباعدة في كلٍ واحدٍ(ّ)، ومن ثم تعني عبارة (النص القرآني) في هذا البحث تناول فرائد بنية التوازي في القرآن الكريم من منظور علم النص الذي يتعامل مع "اللغة لا بوصفها كلمات أو جمل منعزلة، بل في نص مترابط، بدءا من المنطوق المؤلف من كلمة واحدة، حتى المؤلف من عشرة مجلدات"(؛).

( (1) كما هي الحال لدى الكفوي (ته ؟ ـ 1 هـ) (أبو البقاء أيوب بن موسى الحسيني) في كتابه (الكليات معجم

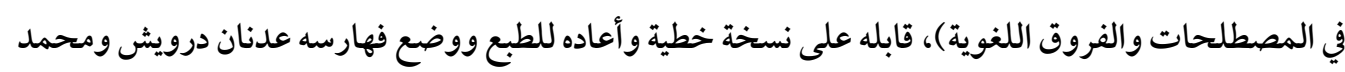

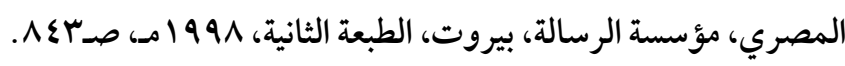
(Y) ينظر قائمة الدراسات السابقة في مقدمة هذا البحث. (†) ينظر الأزهر الزناد، نسيج النص "بحث فيما يكون به الملفوظ نصا"، المركز الثقافي العربي، الدار البيضاء،

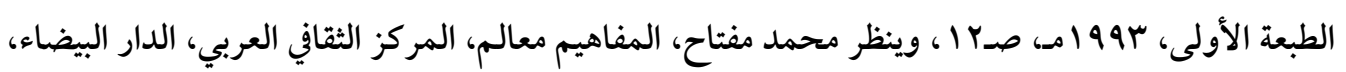

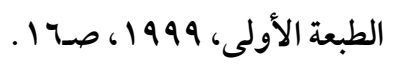
(4)Zellig S. Harris, (Formal linguistics series) Papers in Structural and Transformational Linguistics, Springer (a global publisher), Dec 1, 2013, P315. 
الأسلوبية الإحصائية Statistical Stylistics: "البعد الإحصائي في دراسة الأسلوب هو من المعايير الموضوعية الأساسية التي يمكن باستخدامها تشخيص الأساليب، وتمييز الفروق بينها"( ) ، ولعل هذا الطابع المنضبط للأسلوبية الإحصائية هو ما يتسق مع الهدف العام لهذه الدراسة التي تسعى لتقديم نتائج رقمية حاسمة بشأن الدلالات التكرارية لمفردات النصوص المقدسة، "ويتجه التحليل الأسلوبي (تأسيسا على الاتجاه الإحصائي) إلى رصد ملامح التضاد والتناسب التي أدى إليها اختيار المؤلف"(؟)، ولعل هذه السمة كذلك هي ما استدعت أن تكون إجراءات الأسلوبية الإحصائية منهجا لهذه الدراسة التي تتناول ملامح البنية التناظرية في مجمل النص القرآني، كما أن الخطة المنهجية التي تتبعها هذه الدراسة - حين تتعامل مع النص بوصفه نصا متكاملا لا بوصفه مجموعة منفصلة من الكلمات والجمل - تتسق مع الخط العام للدراسات الأسلوبية الإحصائية - بوجه خاص - والدراسات الأسلوبية - بوجه عام -، حيث يتعارف دارسو الأسلوبية على أنه "إذا كانت الوحدة الكبرى بالنسبة لعلم اللغة هي الجملة، فإن النص بأكمله هو الوحدة الطولية التامة بالنسبة لعلم الأسلوب وتحليلاته"("). وتتعدد "المناهج الإحصائية والرياضية في تحليل الأسلوب"، ولكنها تجتمع في النظر إلى مفهوم الأسلوب بوصفه يعبِّر عن "تردد الوحدات اللغوية التي يمكن إدراكها شكليا في النص "(๕) (1)

والنص:

Language does not occur in stray words or sentences, but in connected " "discourse - fom a one-word utterance to a ten-volume work

$$
\begin{aligned}
& \text { (1) د. سعد مصلوح، الأسلوب دراسة لغوية إحصائية، صـا ه. }
\end{aligned}
$$

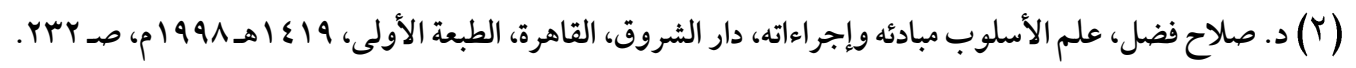

$$
\begin{aligned}
& \text { (Y) د. صلاح فضل، علم الأسلوب مبادئه وإجر اءاته، صـ ؟ ؟ ب. } \\
& \text { ( ) ينظر برند شبلنر، علم اللغة والدراسات الأدبية "دراسة الأسلوب، البلاغة، علم اللغة النصي"، ترجمه وقدم } \\
& \text { له وعلق عليه د. محمود جاد الرب، الدار الفنية للنشر والتوزيع، صده با ـ . }
\end{aligned}
$$


وتختلف هذه المناهج، فبعضها ينتهج إجراءات إحصائية تتسم بالتركيب، وبعضها

يسلك في سبيل ذلك سبلا تتسم بالبساطة، كما هي الحال في المنهج الذي آثره زمب Zemb وأطلق عليه مصطلح "القياس الأسلوبي Stylometrie" "وفيه تُحْصَى كلمات النص وتصنف حسب نوع الكلمة"(')، وبناءً على هذه الإحصاءات المتنوعة، تُنْتبط الخصائص الأسلوبية عن طريق عقد الموازنات والمقارنات بين النواتج المتعددة، بين أكثر من كاتب، أو بين أكثر من نص، من أجل تحديد الخصائص المميزة للنص المرصود، أو للكاتب الخاضع للدراسة، "ومن أهم الميزات التي تعتمد عليها الدراسات التي تعتمد على الكمية استخدام

الحاسب الآلي في التحليل الأسلوبي"(؟). ولعل مما يحتم تطبيق المنهج الأسلوبي الإحصائي في هذه الدراسة التي تستهدف اكتشاف فرائد النص وخصائصه المميزة ما تتسم به الدراسات الأدبية للإحصاء الأسلوبي من اتجاه إلى اكتناه ما يطلق عليه الدارسون اسم (الخصائص المفارقة)، "فقد مرَّ استخدام الإحصاء في دراسة اللغة بمرحلتين، ساد في أولاهما اتجاه يهدف إلى قياس الخصائص العامة أو المشتر كة في الاستعمال the universals أما في المرحلة الثانية فقد ساد اتجاه مقابل هـدفه التوصل إلى الخصائص المفارقة (أو المميزة) بين الأساليب the differential ومن الطبيعي أن يولي دارسو الأسلوب الاتجاه الثاني أكبر اهتمامهم على حين يولي بعض المشتغلين بعلم اللغة العام تطوير الدراسات في الاتجاه الأول"(r). وفي هذا الإطار المتعلق بالدراسات الأسلوبية الإحصائية للقرآن الكريم لا يستطيع الباحث أن يغفل الجهود الهائلة التي سبق إليها الدارسون في إحصاء جُل الظواهر اللغوية في النص القرآني، والتي بدأت بإحصاء المستشرق الألماني "فلوجل" لكلمات القرآن الكريم، وهو

$$
\begin{aligned}
& \text { ( ( ) ينظر برند شبلنر، علم اللغة والدراسات الأدبية، صـا \& ا . }
\end{aligned}
$$

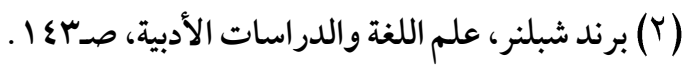

$$
\begin{aligned}
& \text { (r. سعد عبد العزيز مصلوح، الأسلوب دراسة لغوية إحصائية، صـ هـ }
\end{aligned}
$$


الإحصاء الذي سطره صاحبه في كتاب جليل أطلق عليه اسم "نجوم الفرقان في أطراف القرآن"،

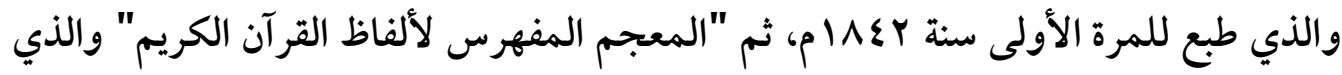
نقل فيه صاحبه محمد فؤاد عبد الباقي المادة التي سبق إلى تصنيفها المعجم المذكور للمستشرق "فلوجل"، وأعاد ترتيبها، وغيَّر مواضع بعض كلماتها، ثم موسوعة "الإعجاز العددي في القرآن الكريم" لصاحبها د. عبد الرزاق نوفل، والتي اتكأ فيها على المرجعين السابقين، ولكنه خصَّ دراسته بإحصاء الكلمات المتر ادفة والمتقابلة في النص الكريم .. . وقد اعتمد هـؤلاء على أسلوب العد اليدوي التقليدي، وهو ما استدعى من الباحث إعادة مراجعة النتائج من خلال أنظمة العد الآلي (الإلكتروني) التي توفرها برامج الحواسب الحديثة وعلى رأسها برنامج (Word)، فكان أن تم تعديل عدد قليل من النتائج والتحقق من صواب

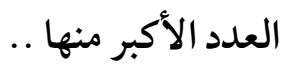
اللراسة المقارنة Comparative Study: تعتمد الأسلوبية الإحصائية في كثير من تجلياتها على المقارنة، "فعندما نقيس أسلوب مشهد ما من الضروري أن نقارن معدلات عناصره اللغوية في مستوياتها المختلفة مع ملامح نص آخر، أو مجموعة أخرى من النصوص التي تُعدٌّ قاعدة ذات علاقة محددة في سياقها بالمشهد الذي نحلله"(')، ولذا أفرز الدرس الأسلوبي Comparative Stylistics المعاصر توجها منهجيا متفردا هو ما يعرف بالأسلوبية المقارنة التي تلتزم بإجراء المقارنة بين نصين مختلفين في الأسلوب لكنهما متفقان في الغرض أو الموضوع (Г) ومن ثم عمدت هذه الدراسة في سعيها إلى بحث آليات عمل البنية التناظرية في مجمل النص القرآني إلى مقارنة معدلات العناصر اللغوية المعبرة عن هذه الآليات في نص الكتاب الكريم مع ما يقابلها في النص التوراتي من خلال النتائج التي توصل إليها “روبرت لوث”

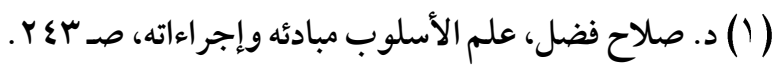
(ץ) فتح الله سليمان، الأسلوبية مدخل نظري ودراسة تطبيقية، الدار الفنية للنشر والتوزيع، القاهرة، •991م) 
في دراسته المذكورة للكتاب المقدس، ومن ثم - ووفقا للمصطلح الأسلوبي الإحصائي - يمكن أن نطلق على نص العهد القديم اسم "النص النمط" والمقصود به النص الذي يجعله الباحث في

مقارنة مع النص المدروس لكي يثبت أنماط الانحر اف في هذا النص ( ). ولعل من الشروط البديهية التي ينبغي أن تتحقق في "النص النمط" أن يشترك مع النص الخاضع للدراسة في الإطار الفكري والثقافي الذي نشأ فيه أو صدر عنه (الإطار الديني)، وكذا في الظواهر المراد إجراء البحث الإحصائي عليها، وهي هـنا ظواهر التوازي التقابلي والترادفي والتركيبي التي أشار “روبرت لوث” إلى تحققها في النص التوراتي .. وقد حظي كتاب “روبرت لوث” بعناية الدراسات المقارنة في الثقافة الغربية، وعُقد عدد من المقارنات بينه وبين نماذج من الأدب العربي مثل مقامات الحريري، كما هو الشأن مع ج. ب. جراي George Buchanay Gray أستاذ الدراسات العبرية بكلية منسفلد وجامعة كامبردج في كتابه "أشكال الشعر العبري"the Formal of Hebrew Poetry (ץ) حيث جعل (جراي) من هذه المقارنة تُكَأَةً لإبراز سمات التميز في النص التوراتي، مقارنة مع التكلف المذموم في مقامات الحريري، وأغفل جراي عمدا أو جهلا وجود الظاهرة في كتاب العربية الأول "القرآن الكريم"، ولا يشفع له أنه يتناول القضية من منظور أدبي في حين إن القرآن نصٌ دينيٌ، وذلك لأنه إنما يعقد المقارنة مع نص ديني آخر هو العهد القديم. ولعل هذا ما دعا عددا من الدارسين الأوربيين إلى فتح باب الدعوة إلى عقد هذه الدراسات المقارنة المفتقدة في إطار آليات التوازي وأشكاله كما هو الشأن لدى د. و. باري

$$
\text { (1) ينظر د. سعد مصلوح، الأسلوب دراسة لغوية إحصائية، صــه. }
$$
(Y) ينظر صـ · ؛ ، والكتاب حصيلة رسالة جامعية أكاديمية حصل بموجبها صاحبها على دراجة الدكتوراه في الكتاب المقدس. 
(') Donald W. Parry

وتبقى ملاحظة مهمة في تحديد ميدان الدراسة المقارنة، حيث ينحصر هذا الميدان في

الظو اهر اللغوية التي لا تختلف في حال ترجمة النص إلى لغة أخرى، ومن ثم تم تجاوز الظواهر التي ترتبط بلغة النص مثل تلك التي تعتمد على المجانسات الصوتية، وما دفع الباحث إلى ذلك إلا تعذر نقل القيمة الأسلوبية عبر اللغات المختلفة في هذه الحال.

وقد فطن “روبرت لوث” إلى هذه النتيجة حين أشار إلى أن عددا من ملاحظاته التي أبداها

في دراسته (محاضرات في الشعر العبري المقدس) مرتبطة بالصياغة اللغوية العبرية، وفي هذا يقول لوث: "على الرغم من كل المحاولات المبذولة لعرض عناصر الجمال الكامنة في الصور العبرية في شعر لغة أخرى، فإن هذه العناصر الجمالية يتحتم سقوطها في النص المترجم"(؟).

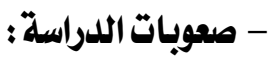
لعل أُولى صعوبات هذه الدراسة تتمثل في الرّهان الصعب الذي يُحْدِقِق بمن يخوض غمار دراسِِ أيٍ من الظواهر القرآية، حيث لا سبيل لأية دراسة قر آنية إلا أن تتجشم عبء مطالعة ما كُّبِبَ فيما يوازيها، وهو غالبا ما يكون كثيفا هائلا، ثم عليها بعد ذلك أن تحدد ما انتهى إليه السابقون، حتى تشقَّ سبيلا مغايرا، وهو أمر شديد الخطورة والصعوبة في آنٍ. الصعوبة الأخرى تتمثل في الدراسة المقارنة مع النص التوراتي من خلال كتاب “روبرت لوث" "محاضرات في الشعر العبري المقدس"، حيث لم يسبق لهذا الكتاب ـ على الرغم من

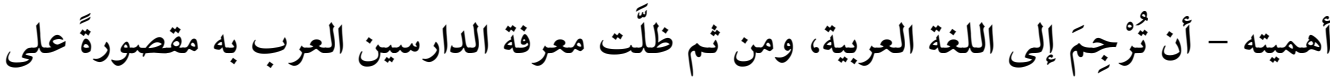

(1)Donald W. Parry, Poetic Parallelisms in the Book of Mormon, The Neal A. Maxwell Institute for Religious Scholarship, Brigham Young University, Provo, Utah, 2007.

(2)Robert Lowth, 1829, ibid, P174. 
إشارات عجلة لم تشف غلة ولم ترو ظمأُ (1)، فلم يجد الباحث بديلا عن إدارة فريق بحثي يقوم على ترجمة الكتاب من الإنجليزية إلى العربية، حيث لاقى هذا الفريق عنتا كبير افي ترجمة كتاب يصل عدد صفحاته إلى أربعة وأربعين وأربعمائة صفحة من القطع الكبير - من جانب - ويتوزع محتواه بين اللغات الإنجليزية واللاتينية والعبرية - من جاب آخر - . وإذا كانت الترجمة مهما بلغت دقتها وحرفيتها تعد خيانة للنص، فترجمة النص الشعري تعد - بحق - خيانة عظمى، ولهذا لجأ الباحث إلى تحديد مواضع الشعر العبري في الكتاب ومطابقتها بأصلها في الترجمة التي اعتمدها اللاهوتيون للعهد القديم من خلال فك طلاسم الأعداد اللاتينية التي انحاز لها مؤلف الكتاب وجعلها بديلا لتحديد أرقام الأسفار والإصحاحات.

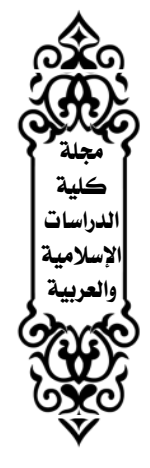

( (1) ولعل أهم هذه الإشارات هي إشارة د. عبد الواحد الشيخ في كتابه البديع والتوازي، صـ II- 


\section{المبحث الأول:}

\section{التناظرية التقابلية}

- التوازي التقابلي في النص التوراتي من خلال دراسة "روبرت لوث"؛ يعرّف “روبرت لوث” هذا اللون من التوازي في النص التوراتي فيقول: "التوازي التقابلي

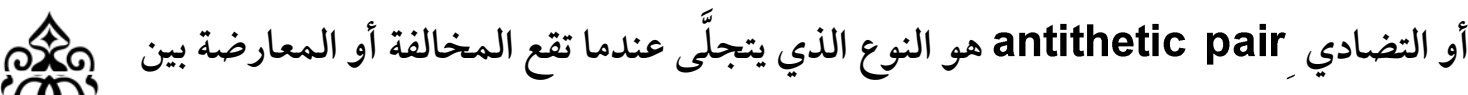
طرفين. وهذا لا يقتصر على شكلٍ بعينه، لأن العبارات تعارض العبارات، والكلمات تعارض الكلمات، والمفرد يعارض المفرد، والجمع يعارض الجمع"(()

وهكذا تنطوي إشارة “روبرت لوث” على تنوع التوازي التقابلي (التضادي) إلى تضادِ بين

كلمتين، وتضادٍ بين عبارتين، ثم ينقسم التضاد بين الكلمتين بدوره إلى مطابقة بين مفرد ومفرد،

ومطابقة بين جمع وجمع، فأما المطابقة بين مفرد ومفرد، فيمثل لها "لوث" بأمثلة عديدة، منها:

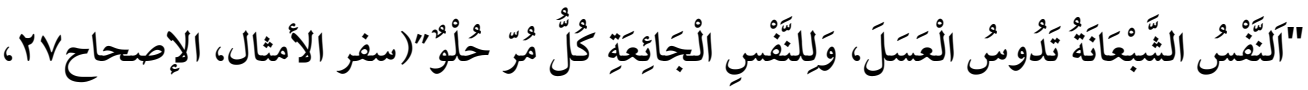

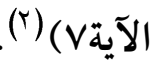

حيث تقع المضادة بين مفردتي "الشبعانة" و"الجائعة"، ومفردتي "مر" و"حلو" ..

وأما المطابقة بين جمع وجمع، فيمثل لها - كذلك - بعدد موفور من الشواهد، منها:

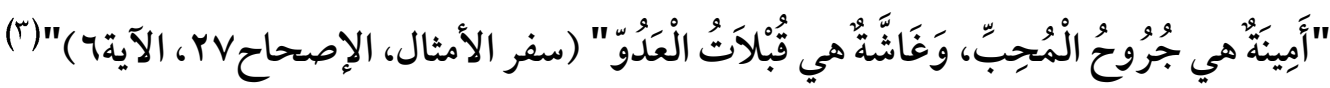

$$
\text { حيث تقع المضادة بين "جروح" و"قبلات". }
$$

أما في حديثه عن المقابلة بين الجملتين فيشير “روبرت لوث" - كذلك - إلى تنوع هذا

اللون من المقابلة بين ما يمكن أن نطلق عليه تضادا بسيطا وتضادا مر كبا، على الوجه التالي: -

(1)Robert Lowth, Lecture on the sacred poetry of Hebrews, p161.

(2)Ibid, p161.

(3)Ibid, p161. 


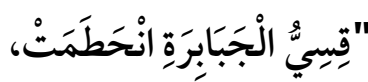

وَالضُّعَفَاءُ تَمَنْطَقُو الِبالْبَأْسِ.

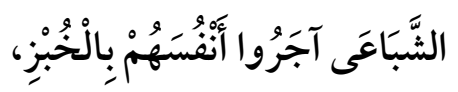

وَالْجِيَاعُ كَفُّو ا.

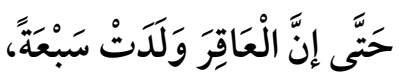

وَكَثَيَرَة الْبَنِينَ ذَبَلَتَتْ

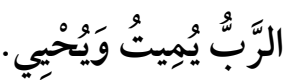

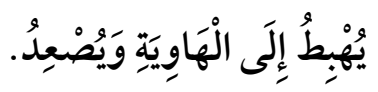

الرَّبُُّ يُفْقِرْ وَيُغْنِي.

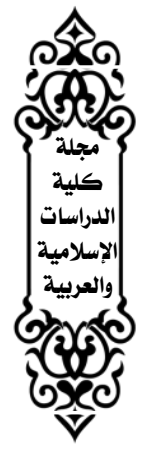

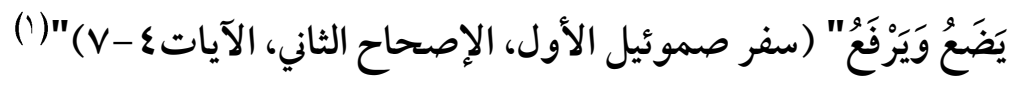

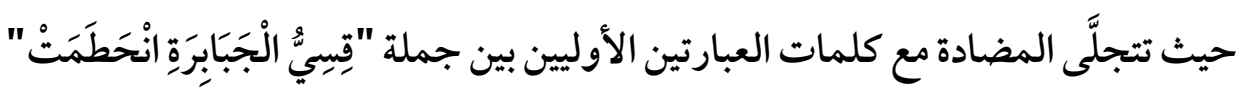

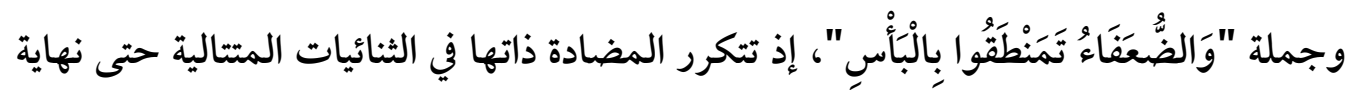
الفقرة، وهو ما يتجلَّى - كذلك - بوضوح - في الثاهد التالي من سفر الأمثال:

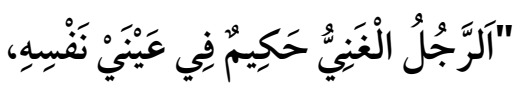

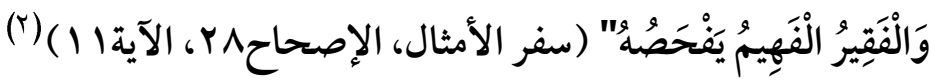
- التضاد المركب: هو الذي يقع حين يوازي التضاد في إحدى العبارتين تضادا آخر في

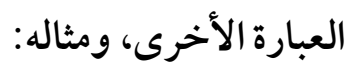

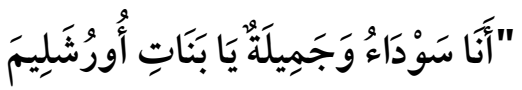

$$
\begin{aligned}
& \text { كَخِيَام قِيَدارَ، كَشُقَقِق سُلَيْمَانَ"(سفر نشيد الإنشاد، الإصحاح الأول، الآيةه ) (َّ) }
\end{aligned}
$$

(1)Ibid, p162.

(2)Ibid, p161.

(3)Ibid, p161. 
حيث يشير “روبرت لوث" إلى أن العبارة الأولى تنطوي على تضاد بين "سوداء" و"جميلة" يوازي في العبارة الثانية تضادا آخر بين "خيام قيدار" و"شقق سليمان"، ومن ثم فالأصل في العبارة - كما يقول لوث - أن تكون صياغتها على الوجه التالي: "سوداء كخيام قيدار، جميلة كشقق سليمان"(')

\section{- التناظرية التقابلية بين روبرت لوث والدراسات القرآنية:}

أولا: اتسقت تفرقة "روبرت لوث" بين التضاد في المفردات والتضاد في العبارات مع

تفرقة البلاغة العربية بوجه عام والبلاغة القر آنية على وجه الخصوص بين الطباق والمقابلة ..

ثانيا: لم يرد في مصنفات البلاغة القرآية ولا في مصنفات البلاغة العربية - بوجه عام - ما

يشبه هذه القسمة الثانية التي رسَّخها “روبرت لوث” بين طباق المفرد وطباق الجمع، بل كان الأمر على النقيض من ذلك، حيث تناول البلاغيون أحوال الخروج على هذه المطابقات المعيارية القائمة على الموازاة الشكلية التامة، وتناولوا - من خلال وعي فني مقصود - صورة المطابقة بين الجمع والمفرد ضمن باب أطلقوا عليه اسم "الطباق الخفي" تارة أو "الطباق الخلافي"(؟)، أو "مقارنة الشيء بما يقرب من مضاده"(؟) تارة أخرى، وهو اللون الذي ستتناوله هذه الدراسة تحت تسمية "العدول عن المطابقة". ثالثا: يتسق اللون الأخير من ألوان المضادة التي رسخها روبرت لوث وأطلق عليه تسمية "التضاد المركب" مع القسم الثاني من أقسام المقابلة القرآنية متعددة الأطر اف، وهو النوع الذي أثبته الزركشي في كتابه "البرهان في علوم القرآن" وقصد به ورود الطرفين الثانيين للطباقين في

(1)Ibid, p161.

(Y) الزر كثي، البرهان في علوم القرآن، (الإمام بدر الدين محمد بن عبد الله بن بهادر)، البرهان في علوم القرآن،

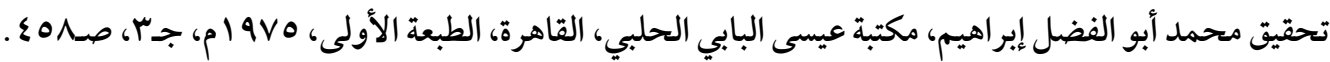

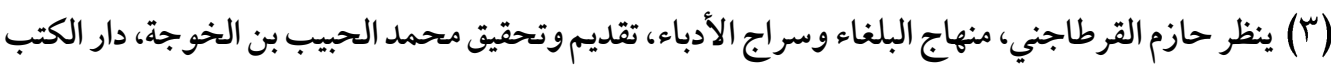

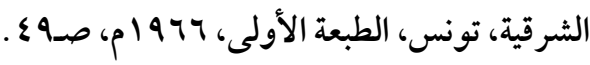




\section{المجلد الثامن والثلاثون إصدار يونيو.r.r.}

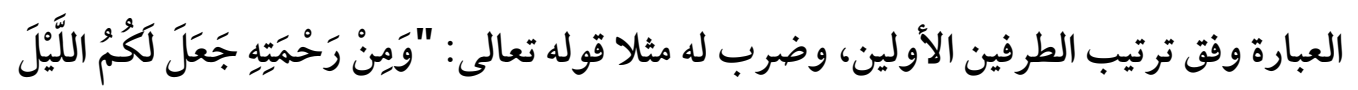

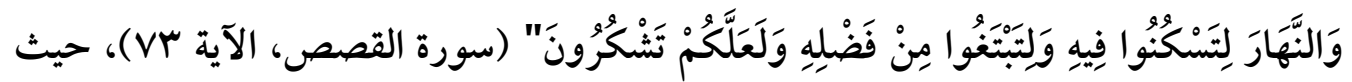

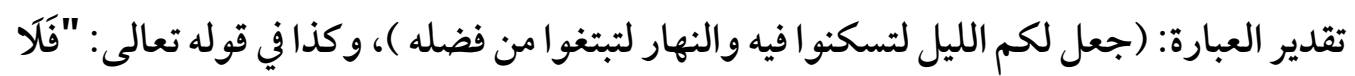

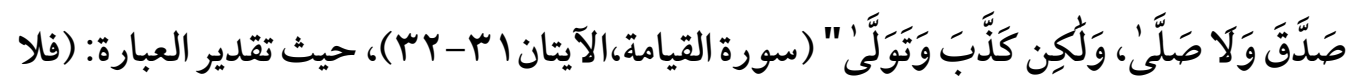
صدق ولكن كذب ولا صلى ولكن تولَّى )... . وهكذا فإذا كانت تسمية (التضاد المركب) تنصرف على لون واحد من ألوان المقابلة عند "روبرت لوث" في دراساته نصوص التوراة فإن صور هذه المضادة تتعدد في الدراسات القرآنية

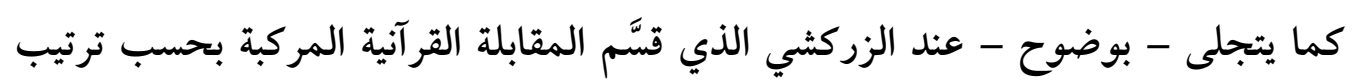
أطر افها إلى أربعة أقسمه على الوجه التالي:

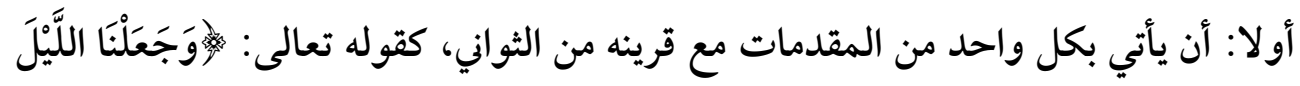

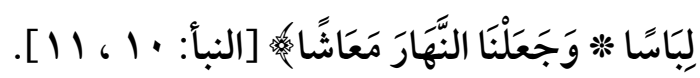

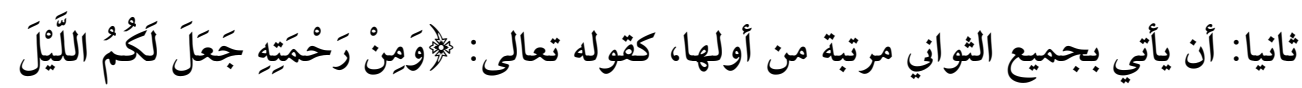

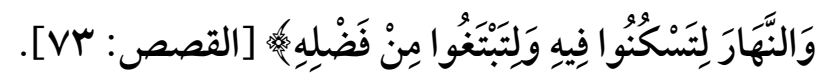

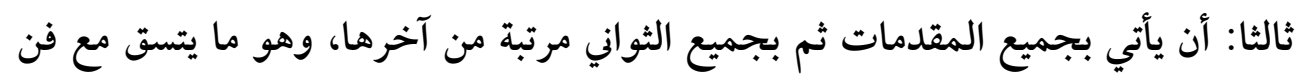

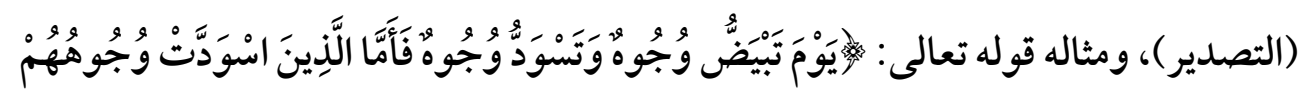

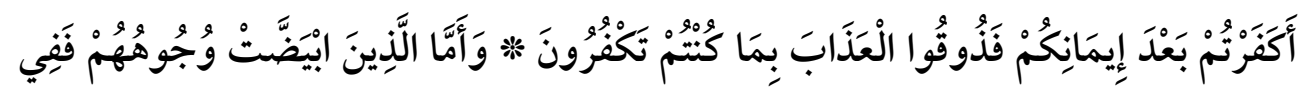

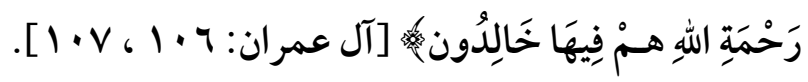

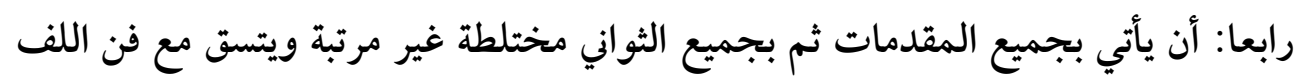

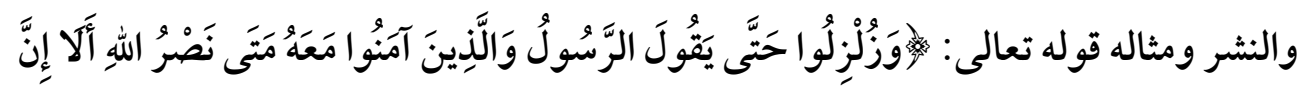

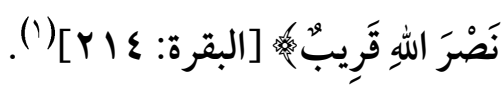
وبوجه عام هنالك ثلاثة فوارق رئيسة بين تصورات روبرت لوث للتوازي التقابلي في 


\section{فرائد الينية التناظرية في النص القرآني (دراسلة اسلوبية إحصائية مقارنة)}

النصوص التوراتية وتصورات دارسي النص الكريم للتناظريات التقابلية في القر آن، وهذه الفوارق

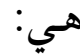

أولا: توقفت دراسات روبرت لوث عند طرح الاختلافات الشكلية/ المعيارية بين أنماط التوازي التقابلي من خلال طرح عدد من الشو اهد التي تمثّل كلَّ نمط من هذه الأنماط، دون أن تتجاوز ذلك إلى دراسة القيم الجمالية الكامنة في هذه الأنماط الشكلية وتلك النصوص التي تمثلها.. ثانيا: توقفت خطة روبرت لوث في استباط أشكال التوازي التقابلي عند دراسة الكلمات والعبارات المتجاورة، في حين تجاوزت الدراسات القرآنية هذه الخطة وتناولت المقابلات القر آنية بين الكلمات أو العبارات دون أن تتقيد بشرط المجاورة، بل طرحت الدراسات القر آنية دراسات مستفيضة عن العبارات المتقابلة معنويا وتركيبيا في مجمل النص القرآني، وهو ما ستتناوله هذه الدراسة في موضعه ... ثالثا: توقف التوازي التقابلي عند روبرت لوث عند حدِّ الكلمة والكلمتين (الطباق) سواء في حال الإفراد أو الجمع، أو الجملة والجملتين (المقابلة) سواء في حال التضاد البسيط أو المركب، في حين تجاوزت الدراسات القر آنية ذلك الإطار الضيق لتعبّر عن الآفاق المتدرجة للنص القرآني، بدءا من مستوى الكلمة، إلى مستوى الجملة، ثم مستوى السورة القر آنية، انتهاء بمستوى النص

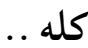

\section{- التناظرية التقابلية على مستوى الكلمة والعبارة:}

وتتجسد فر ائد التناظرية التقابلية على مستوى الكلمة والجملة في النص القر آني من خلال المقارنة بين الدراسات القرآنية - من جانب - ودراسات روبرت لوث للنص التوراتي - من جانب آخر - في محورين رئيسين: - أولا : مبدأ العدول عن المضادة المعيارية/ القياسية. - ثانيا: مبدأ "التعليل" أو (علاقة الشكل بالمضمون). وفيما يلي تفصيل لهذين المحورين: 
المجلد الثامن والثلاثون إصدار يونيو.r.r. r.

أولا : مبلأ العدول عن المضادة المعيارية/القياسية: هنالك لونان من التضاد الذي يقع في الطباق والمقابلة.. - اللون الأول : التضاد القياسي (أو التضاد المعياري) الذي يتحقق في ثنائيات (الأبيض والأسود) أو (الأعلى والأسفل).

- اللوذ الثاني: التضاد الخلافي (أو التضاد المراوغ) الذي يتحقق في ثنائيات (الأبيض والأحمر ) أو (الأعلى والأوسط).

واللون الأول يمثل الصورة المعيارية/ القياسية للمضادة، أو الصورة التي لا يتحقق من

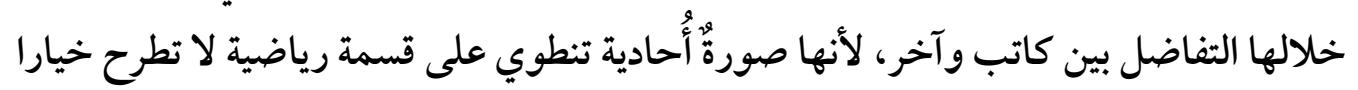

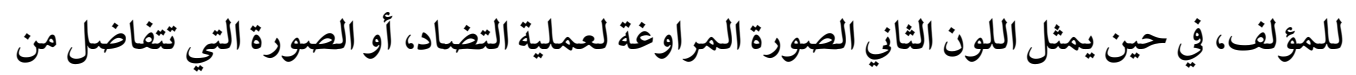
خلالها النصوص لما تتيحه للمبدع من تعدد الخيارات وإمكانيات الاستبدال والخروج على لى مقتضى ظاهر التركيب المعياري الجامد والقياسي المقعَّد.

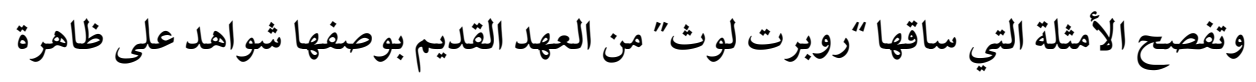
التوازي التقابلي (التضاد) عن تمثيل هـذين النوعين من المضادة (المعيارية القياسية والخلافية المراوغة)، حيث حرص النص التوراتي على بلوغ الطباق أو المقابلة الدرجة المثالية/ المعيارية

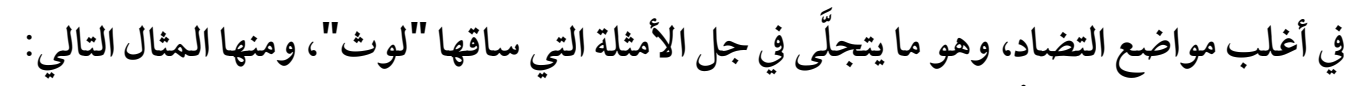

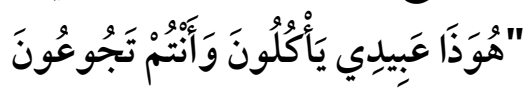

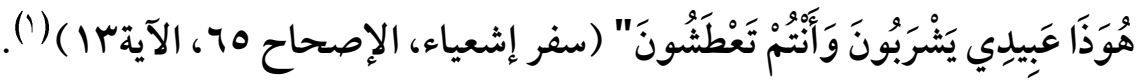

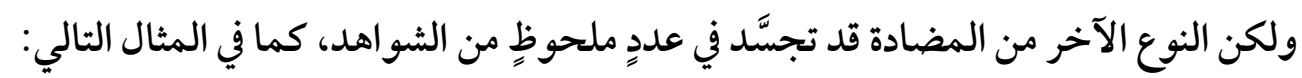

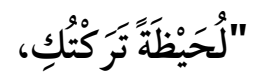

$$
\begin{aligned}
& \text { وَبِمَرَاحِمَ عَظِيمَةِ سَأَجْمَعُكِكِ. }
\end{aligned}
$$

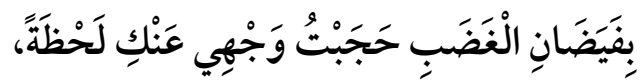

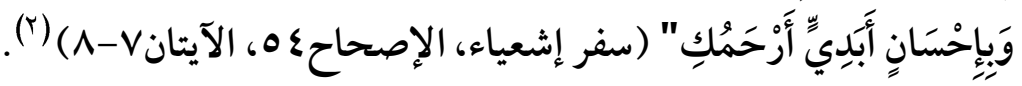

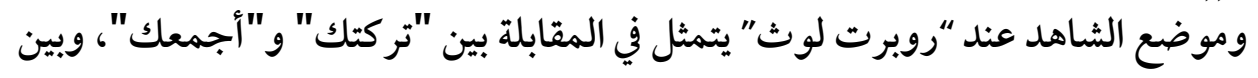

(1)Robert Lowth, Ibid, p161.

(2)Ibid, p162. 
"الغضب" و"إحسان" وبين "حجبت وجهي عنك" و"أرحمك"، وتندرج هذه المقابلات تحت قائمة المقابلات المنقوصة، حيث عدل النص التوراتي عن استخدام المقابلة المعيارية (القياسية) بين "تركتك" و(أخذتكِ) أو بين "سأجمعكِ" و(سأفرقلِ) أو بين "الغضب" و (الرضى) أو بين "إحسان" و(إساءة) أو بين "حجبت وجهي عنِكِ" و(وجهت وجهي إليكِ) أو بين "أرحمك" و (أقسو عليكِ) ولكن “روبرت لوث" لم يلحظ هذه القسمة فيما أثبته من أنواع

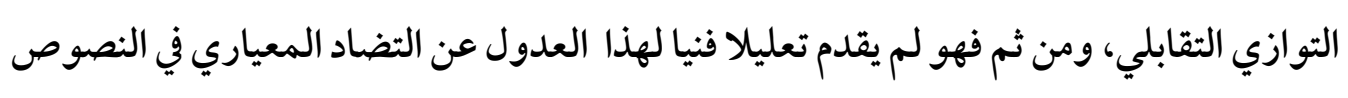
التوراتية.

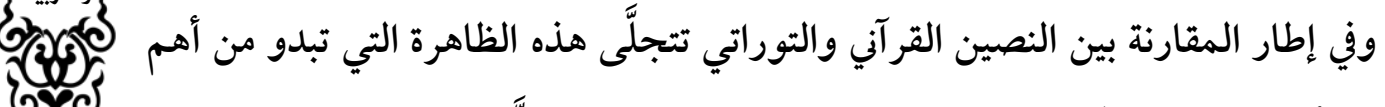

الظواهر الأسلوبية التي تعبِّر عن خصوصية السياق القرآني فيما يتعلَّق بالتناظر التقابلي، والتي تفصح عن أن النص القر آني لم يستخدم المقابلات والطباقات بوصفها آليات تزيينية مجردة تتسم بالمعيارية/الأحادية، ولكنه استخدمها بوصفها تعبيرات تتسم بالمراوغة الجمالية من خلال دورها المشهود في إثراء الدلالة والتعبير، حيث اتسمت المقابلات القر آنية بحساسية خاصة في ائتلافها مع سائر العناصر الأسلوبية في السياق القر آني، حتى إن هذه العناصر الأسلوبية قد دفعت هذه المطابقات في عددٍ من المواقف القرآية إلى تجاوز البنية المعيارية/ الشكلية للمقابلة من أجل تحقيق غايات فنية ذات أثر، والتي تبدو تجلياتها في الأمثلة التالية:

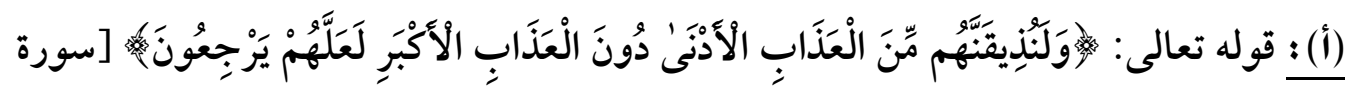

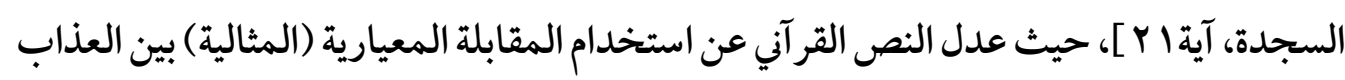
الأدنى والعذاب الأعلى أو بين العذاب الأصغر والعذاب الأكبر، وذلك مراعاة للعناصر الدلالية والتعبيرية التي ينطوي عليها السياق القرآني، فالمراد بالعذاب الأدنى المصائب والآلام التي تصيب الكافرين في الدنيا" (') ومن ثم فقد عدل القر آن الكريم عن وصفه بـ(العذاب الأصغر ) على

( (1) ينظر أبو جعفر محمد بن جرير الطبري، جامع البيان عن تأويل آي القرآن، حققه وخرَّج أحاديثه محمد

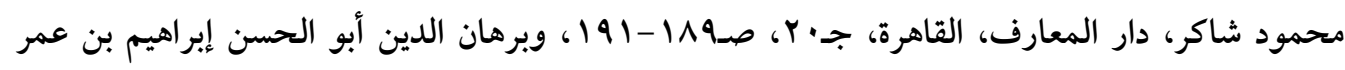




\section{is}

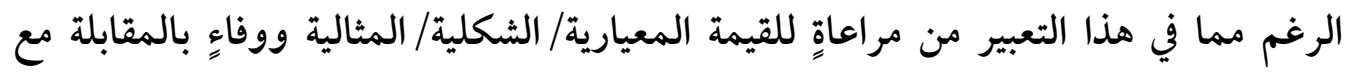

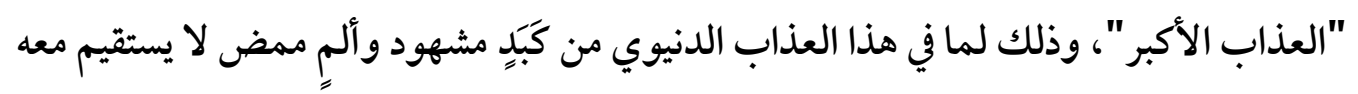

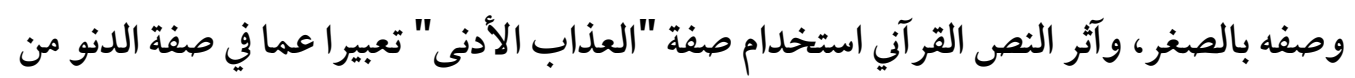
تماهٍ مع متر ادفات الدناءة والضعة وارتباط بمكابدات الدنيا .. .

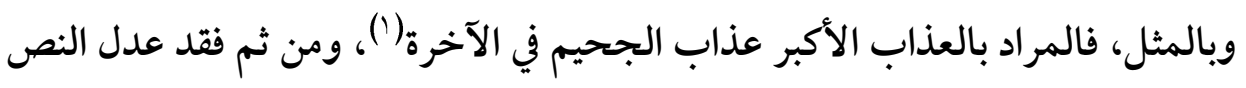
القرآني عن استيفاء عناصر المقابلة المعيارية الشكلية المتحققة في عبارة (العذاب الأعلى) حين العين تقابل عبارة "العذاب الأدنى"، وذلك لما في صفة العلو من مترادفات السمو والرفعة، وهي

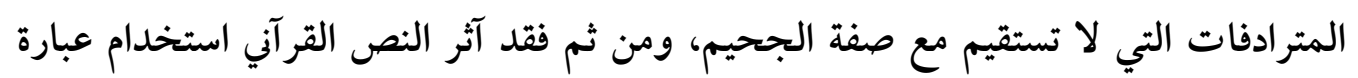

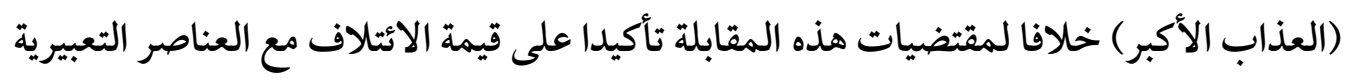

$$
\text { والدلالية المرتبطة بسياق التعبير عن الجحيم. }
$$

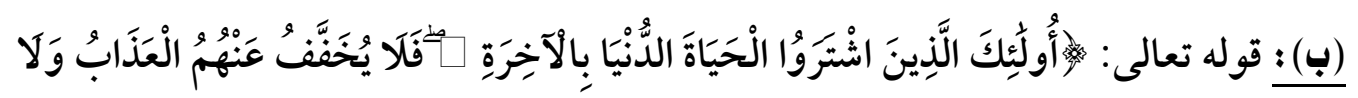

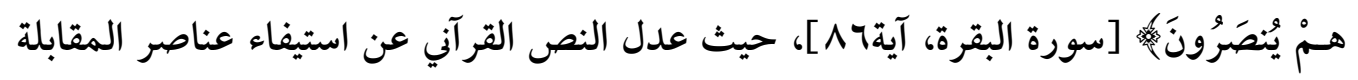

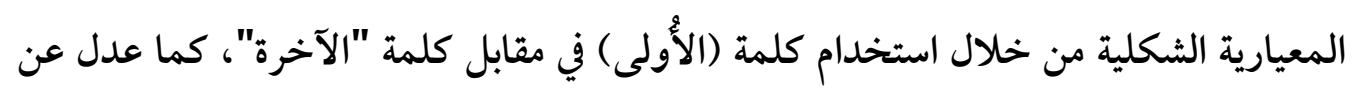

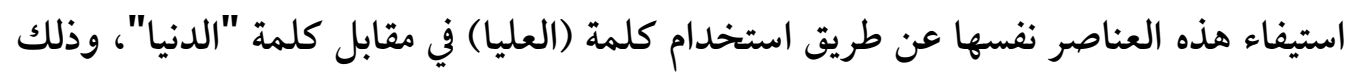

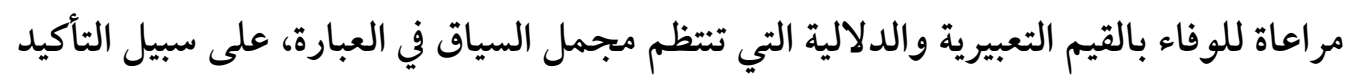

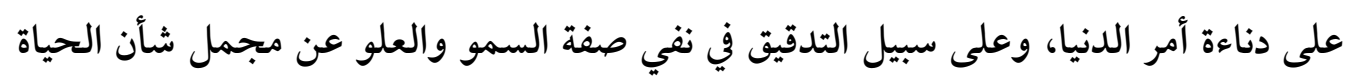

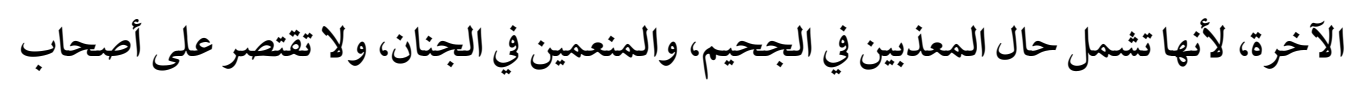
النعيم فقط.

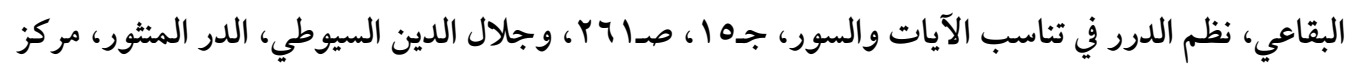

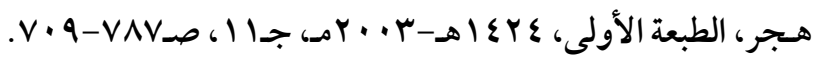

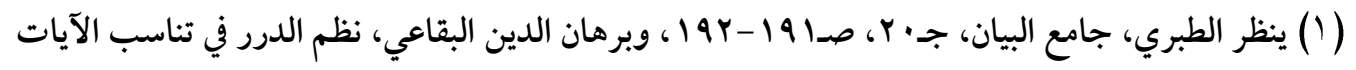

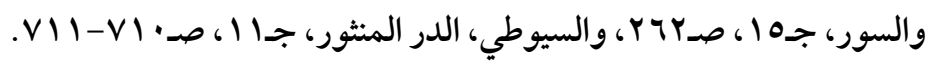




\section{فرائد البنية التناظرية في النص القرآني (دراسلة اسلوبية احصائية مقارنة)}

وقد اجتمعت ثنائية "الدنيا" و"الآخرة" في الكتاب الكريم أكثر من خمسين مرة، وهو ما

يدل على مدى ركون النص القرآني إلى الوفاء بمقتضيات القيمة الدلالية والتعبيرية في السياق القرآني على حساب استيفاء القيم المعيارية الشكلية للطباق المجرد.

ورغم ذلك جاءت الثنائية في عدد من آيات القر آن الكريم على مقتضى المقابلة الشكلية

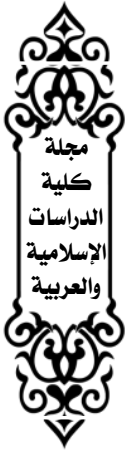

$$
\text { المجردة في كلمتي "الأولى" و"الآخرة" في خمسة مواضع هي: }
$$

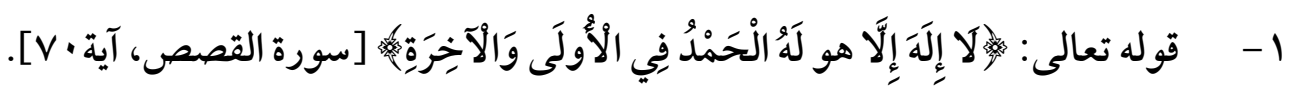

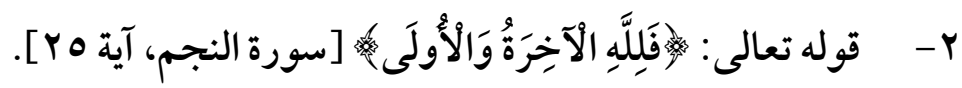

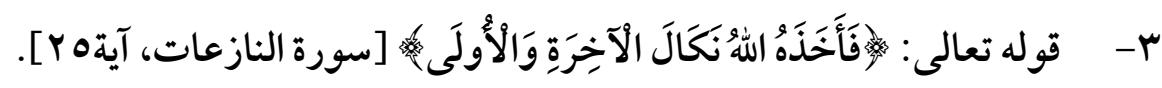

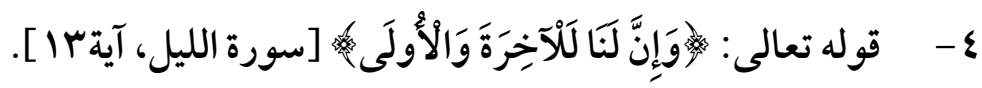

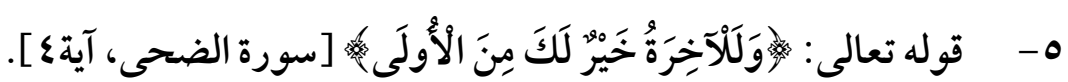

وقد اقتضى السياق في هذه المواضع استخدام كلمة "الأولى" بدلا من "الدنيا"، فني الآية

الأولى آثر النص القرآني استخدام كلمة "الأولى" على كلمة "الدنيا"، لأن السياق الذي وقعت فيه الكلمة هو سياق إزجاء المخلوقات الحمد لله تعالى في الدارين، ومن ثم لم يكن هنالك ما يقتضي استدعاء صفة الزراية بالحياة الأولى، أو تمييزها بالإزراء عن الحياة الأخرى، وفي الآية الأخيرة كان الخطاب موجها إلى النبي صلى الله عليه وسلم، ومن ثم تنتفي موجبات وصف

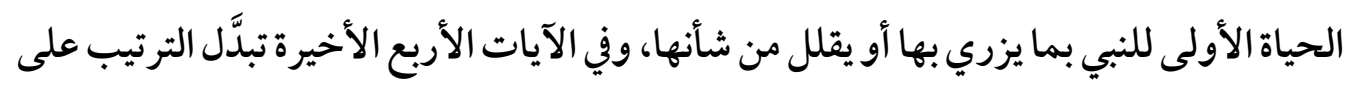
خلاف ماوقع في الآيات التي التصقت فيها الكلمتان في ثمانية عشر موضعا(') وذلك لأن من بين آيات النص الكريم التي تجاورت فيها الكلمتان مو اضع انفصل فيها موقع كلمة الآخرة عن موقع

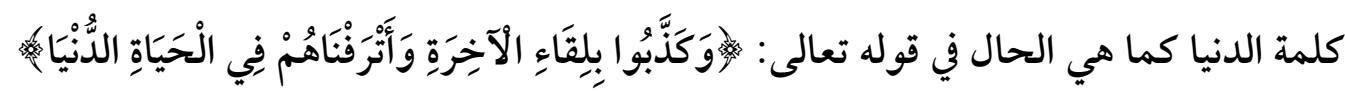
(سورة المؤمنون، آية بr)، ومثل هذه المو اضع لا تدخل في إطار هذه المقارنة، فبدأ النص الكريم بذكر الحياة "الآخرة"، ومن ثم فقد اقتضى اختلاف الترتيب إهمال صفة "الدنيا" واستخدام

( (1) ستة عشر موضعا تتصل أطر افها بحرف العطف (الواو)، وموضعان يتصل طرفاهما بحرف الجر (الباء) .. 


\section{المجلد الثامن والثلاثون إصدار يونيو·r.r. r.}

صفة "الأولى"، لأن السياق القر آني يتعلق بالمقارنة المقصودة بين حال ما تأخر زمنه وتقدم ذكره بحال ما تأخر ذكره وتقدم زمنه، للتأكيد على إحاطة الله بأمر الدارين آخرا وأولا، أو شمول نكال الله مَن حق عليه عذابه في كل زمان وفي كل حياة.

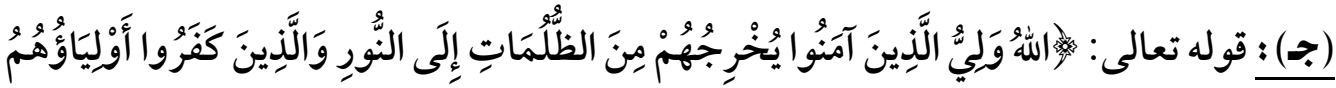

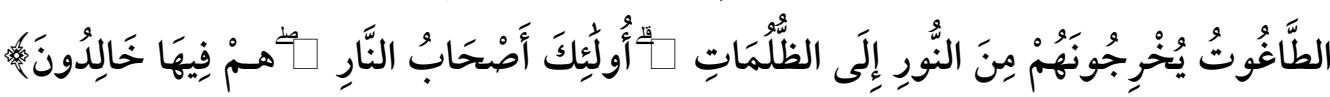
(سورة البقرة، آية Y ) )، حيث عدل النص القرآني عن استيفاء المقابلة المعيارية الشكلية بين الجمع والجمع (الظلمات والأنوار) أو بين المفرد والمفرد (الظلام و النور)، وذلك وفاءً بالقيم التعبيرية والدلالية التي يقتضيها هذا السياق المقدس، حيث إن النور متصل باله الواحد الأحد، والله واحد لا شريك له، أما الظلمات فمتصلة بطواغيت الإنس والجن، وهي متعددة ومتضاربة ومتناقضة، وطريق الحق واحدة، أما طرق الباطل فمتشعبة ومتعددة ومشتبكة..

وقد تعددت الآيات القر آنية التي تجاورت فيها الكلمتان المذكورتان فبلغت اثنتى عشرة مرة( )، لم يقع في إحداها أن جاءت مفردة النور في صورة الجمع أو مفردة الظلمات في صورة الإفراد، وهو ما يدل على قصديةٍ أسلوبيةٍ تُرَسُُِّ هذا المنهج القرآني في العدول عن استيفاء مقتضيات الصياغة الشكلية المعيارية للمطابقة الكاملة في سبيل الوفاء بمقتضيات القيم التعبيرية والغايات الدلالية للسياق القر آني. وتدل مر اجعة الكلمات الواردة في كتاب الله الكريم على أن كلمة "النور" لم ترد في صورة

$$
\text { ( ) ينظر معجم فلوجل المسمَّى "نجوم الفرقان في أطر اف القرآن }
$$

Gustavus Flugel, concordantia corani arabicae, edition stereotyba caboli tauchnitil, lipsiae, 1875"(

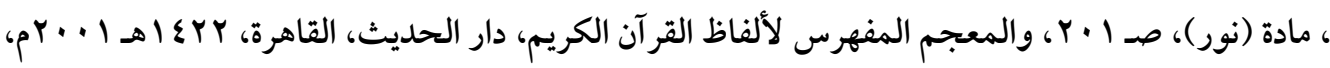

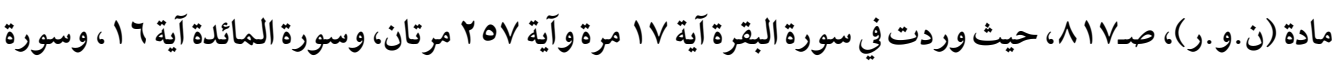

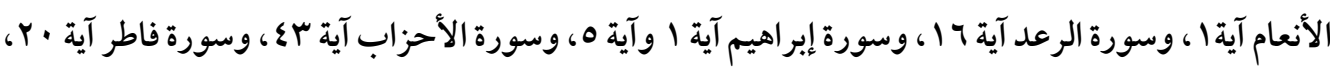

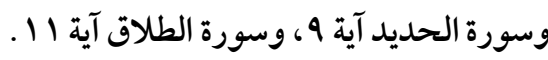


الجمع قط، كما لم ترد كلمة "الظلمات" في صورة المفرد كالظلام أو الظلمة قط، وهو ما يضيف قرينة أخرى إلى قصديَّة الأسلوب القرآني في تحقيق المطابقة القر آنية على هذا الوجه الخلافي، ويتجلَّى تفرد النص القر آني في هذا السياق من خلال المقارنة مع نص العهد القديم، حيث افتقد النص التوراتي هذه البنية المحكمة وتعدد ورود لفظ الظلام أو الظلمة مفردا مائة وعشر مرات كما تعدد ورود لفظ الأنوار مجموعا ثلاث مرات، وجاءت ثنائية (النور والظلمة) على صورة الإفراد مرتين كلتاهما في سفر التكوين الإصحاح الأول الآيتين الرابعة والثامنة عشرة، وعلى الرغم من ذلك بقيت آية توراتية وحيدة تشير إلى رسوخ هذه الثنائية القر آنية (الظلمات والنور) في نص التوراة على هذا الوجه المثبت في القرآن الكريم من جمع الظلمات وإفراد النور في الآية

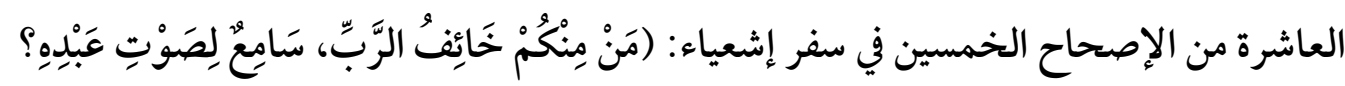

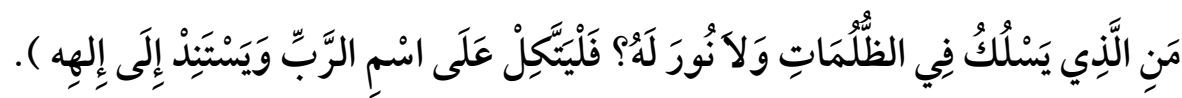

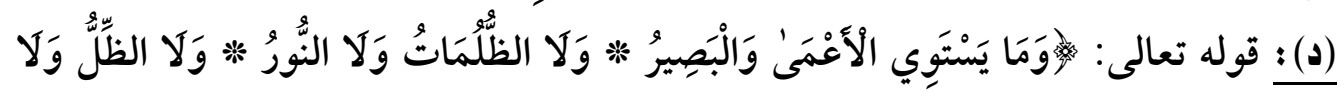

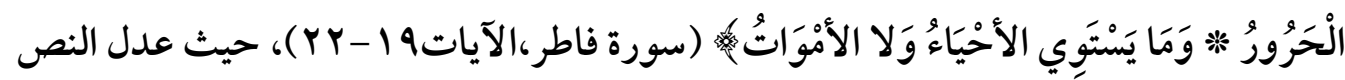
القرآني في ثنائية (الأعمى والبصير) عن استخدام كلمة (المبصر ) بما تحققه من مقابلة معيارية مثالية مع كلمة "الأعمى" إلى استخدام صفة المبالغة "البصير" التي تختلف وزنا واشتقاقا، كما عدل في ثنائية (الظل والحرور) عن استخدام كلمة (الحَر) في صورة الإفر اد بما يتوفر فيها من مطابقة معيارية في مقابل كلمة "الظل" التي جاءت مفردة إلى استخدام كلمة الجمع "الحرور"، وفيما يتعلق بالثنائية الأولى هنالك تأويلان: الأول : حاسة البصر - شأنها في ذلك شأن حاسة السمع - لا تؤثر في وعي صاحِبِها إلا إذا صاحَبَها إدراك وقصد من جانب من يرى ويسمع، فقد تمر العين على كثير من المشاهد دون أن يَعْلَقَ في ذاكرة الرائي شيء إلا إذا كان صاحب البصر متبصرا عن وعي أو مستبصراعن قصد، وهذا كذلك - شأن حاسة السمع، فقد تمر على الآذان أحاديث وعبارات لا يُلقي لها السامع بالا إلا إذا كان سَمِيعا مترصدا عن قصد ووعي، ولهذا جمع الحق تبارك وتعالى الكلمتين معا على 


\section{الإجلد الثامن والثلاثون إصدار يونيو.r.r.}

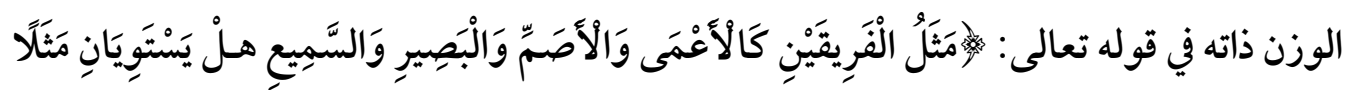

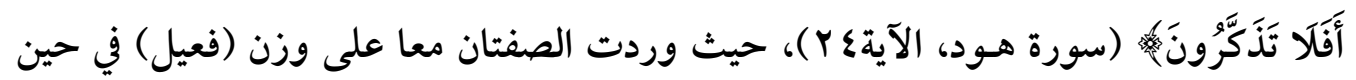

$$
\text { اشترك ما يقابلهما في وزن (أفعل) }
$$

الثاني: البصير صفة مشبهة تدل على الثبوت والرسوخ واسم فاعل يدل على التجدد، ومن ثم

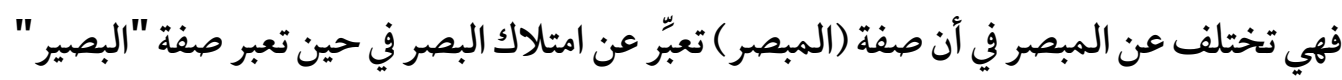
عن امتلاك البصيرة التي تتجاوز التعبير عن الرؤية الجسدية إلى التعبير عن الرؤية الروحية، ومن

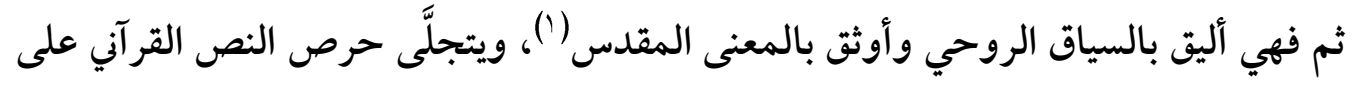

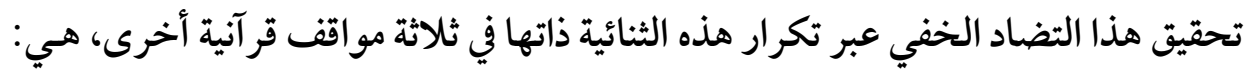

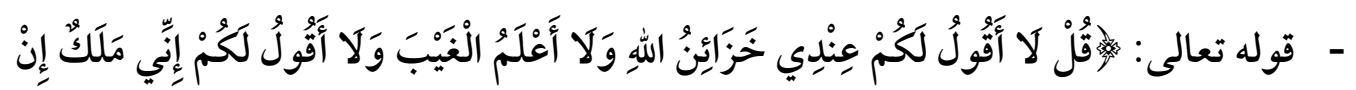

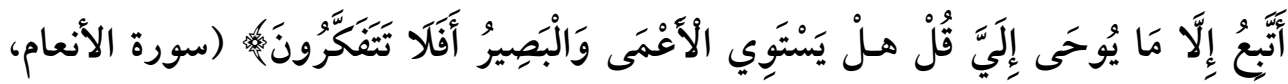

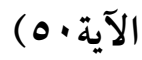

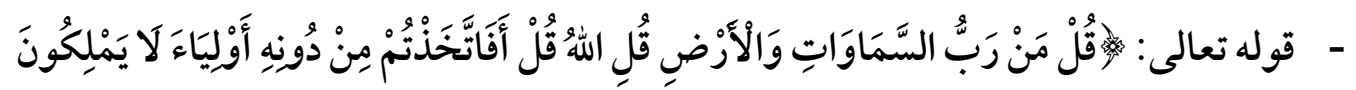

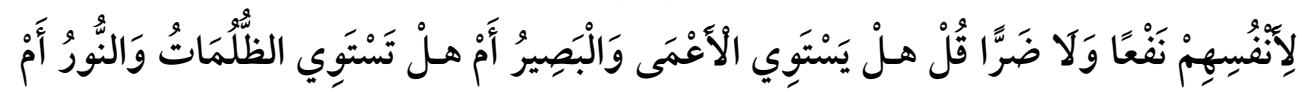

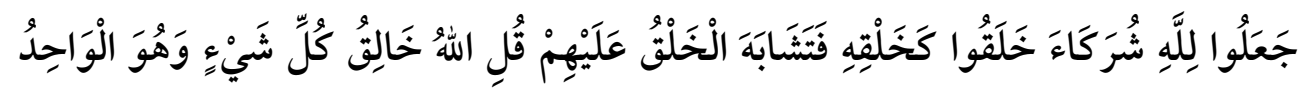

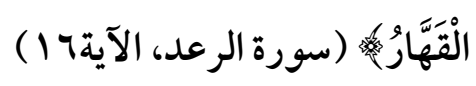

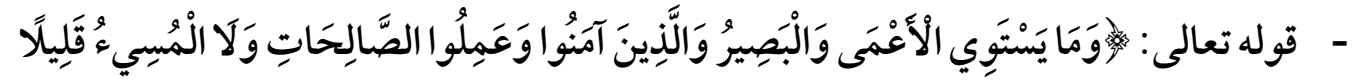

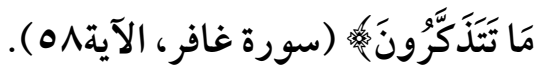
- ولعل هذا التكرار المقصود لهذه الثنائية المتضادة في أضعاف النص الكريم على هذا الوجه من الطباق الخفي يؤكد الفارق بين عقاب الله وثوابه، فالحاسة المادية للعبد الصالح (البصر ) تتضاعف بمثوبة الله لتحقق (البصيرة)، في حين إن الحاسة المادية للعبد الفاسد تتعطل لأنها ( (1) حيث عبَّرت المفردة نفسها في مواضع قرآنية أخرى عن صفة من صفات الله الكريمة واسم من أسمائه الحسنى. 


\section{فرائد البنية التناظرية في النص القرأني (دراسة اسلوبية إحصائية مقارند)}

لم تحقق الغاية من وجودها في التعرف إلى آيات الله، ولعل هذا ما يتجسد - كذلك - في

المقابلة بين صفتين متتاليتين للكافرين وصفتين أخريين متتاليتين للمؤمنين في الآية ؟ ؟

$$
\text { المذكورة سالفا من سورة هود. }
$$

- أما فيما يتعلق بثنائية (الظل والحرور) فيقَّال فيها ما قيل في أمر الظلمات والنور من إفراد الحق الو احد وتشعب الباطل المتعدد ..

- ويدل سياق الآيات الكريمات على مدى الإحكام المتحقق في النص القرآني في التفرقة بين الطباق الخفي والطباق المعياري، حيث تجتمع الآيات الثلاث الأولى في نفي واحد في قوله تعالى: فاطر،الآيتان 19 - (Y) ) ، وهي الآيات التي انطوت على الطباقات الخفية/ المعنوية/ الخلافية في حين تنفرد الآية الأخيرة بنفي استئنافي يفصح عن خصوصيتها الفنية والسياقية، وهو ما

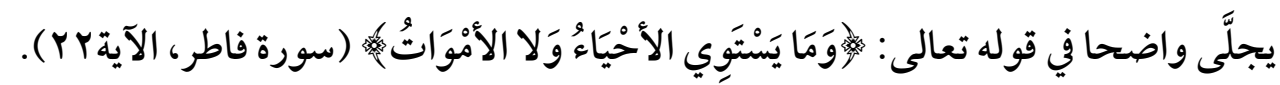

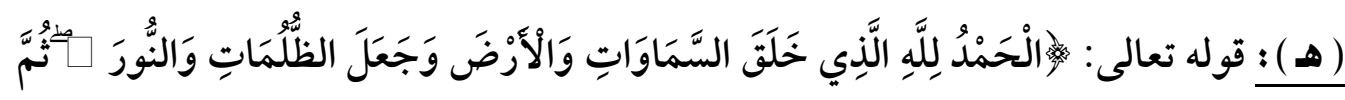

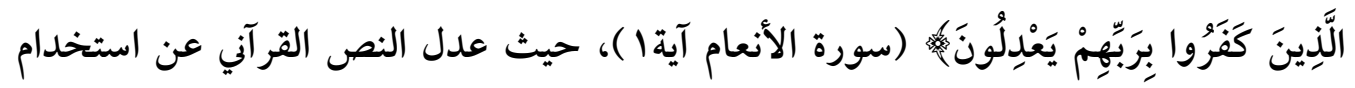
التوازي الشكلي في المقابلة بين السماء والأرض أو السماوات والأرضين، وذلك استيفاءً للقيمة

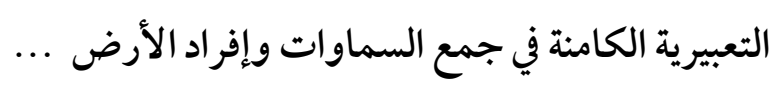

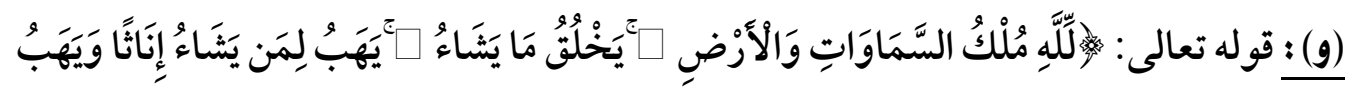

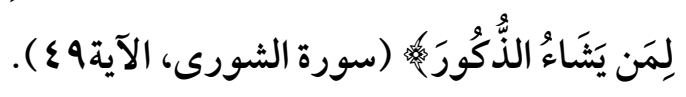
- حيث عدل النص الكريم عن استخدام التناظر المعياري القياسي في المقابلة بين إناث وذكور في صورة التنكير أو بين الذكور والإناث في صورة التعريف، وذلك استيفاءً للقيم البلاغية

$$
\text { الكامنة في تنكير الإناث وتعريف الذكور. }
$$

- م وفي تأويل هذا يذكر القرطبي أن الله تعالى بدأ بذكر الإناث فقدم ما كان يؤخره أهل الجاهلية من الاحتفاء بأمر البنات حتى كانوا يئدونهنَّ فكان لسان حال النص الكريم أن هذا النوع 


\section{المجلد الثامن والثلاثون إصدار يونيو.r. r.}

المؤخر عندكم في الاحتفاء مقدم عند الله تعالى في الذكر، ثم نكَّر النص الكريم الإناث وعرَّف

الذكور، فجبر نقص الأنوثة بالتقديم، وجبر نقص التأخير للذكور بالتعريف(').

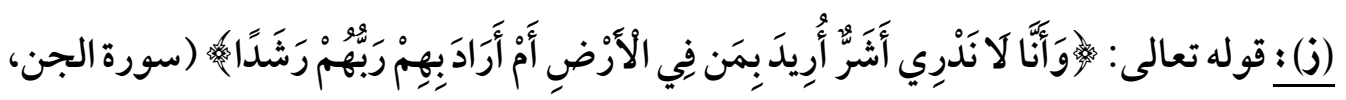
آية + ( )، حيث عدل النص القرآي عن استخدام الثناظر المعياري الشكلي في مقابلة الثر بالخير أو الَََََّد بالغي، وذلك استيفاءً للقيمة التعبيرية الكامنة في مقابلة الشر بالرشد، ومثل هذا يقال في

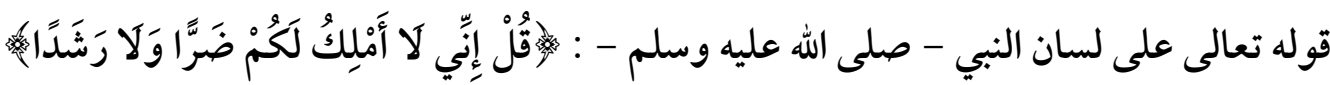

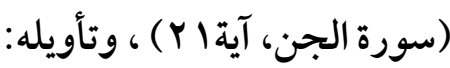

أولا : إن الرَّشد يعنى المفهوم الجامع لصواب المقصد بكل ما ينطوي عليه أو يتجلَّلى من خلاله من الخير في الآية الأولى أو النفع في الآية الثانية، ومن ثم أشار صاحب اللسان إلى أن الرََََّدَ لا

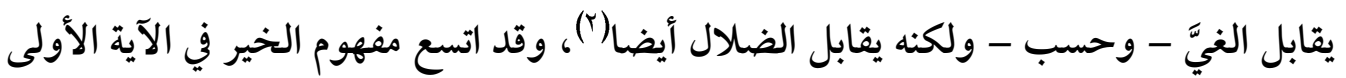
ليعبر عن أصل كل خير ومنبعه، وذلك لأن الأمر قد أُسند إلى الله تعالى في قوله : "أم أراد بهم ربهم"، وقد اقتضى إسناد الأمر اله تعالى أن تعبر الكلمة عن أصل الصفة وجوهرها لا عن

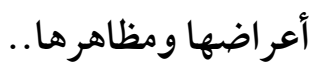

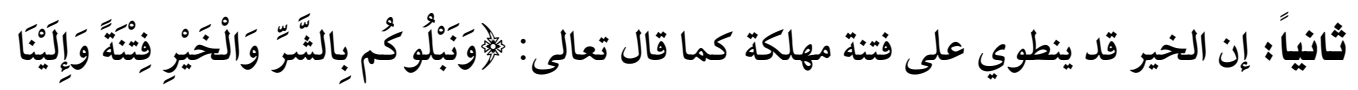

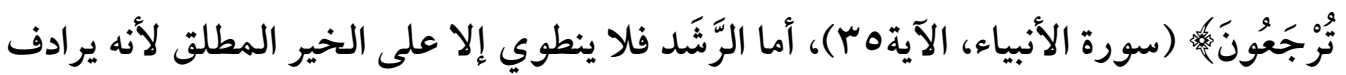

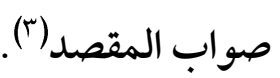

( ( ) ينظر تفسير القرطبي (أبي عبد الله محمد بن أحمد الأنصاري)، دار الريان للتراث (طبعة خاصة بتصريح من

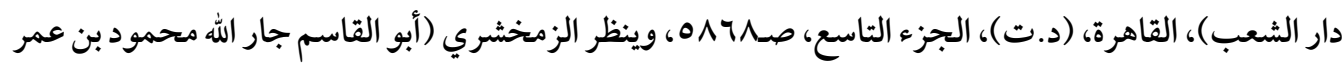
الخوارزمي)، الكثاف عن حقائق التنزيل وعيون الأقاويل في وجوه التأويل، شرحه وضبط مراجعه يوسف إنف

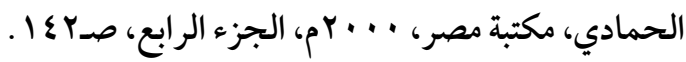

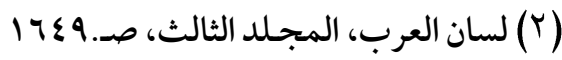

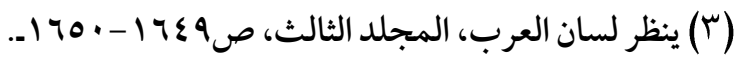


ثالثا : في كتاب الله الكريم - أيضا - ما يؤكد هذا المنحى الذميم للخير الذي يحبه الإنسان فيلهيه عن الصواب بوجه عام أو عن ذكر ربه خصوصا، وذلك في قوله تعالى على لسان النبي سليمان

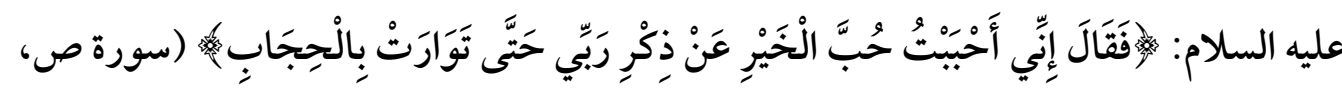

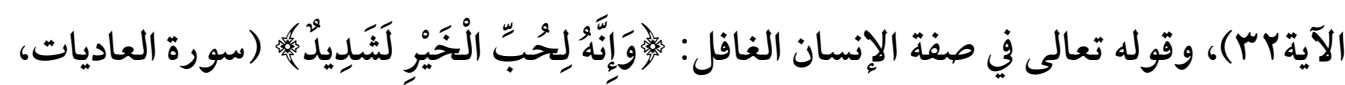

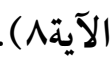

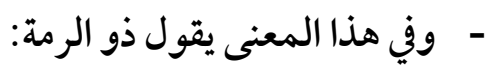

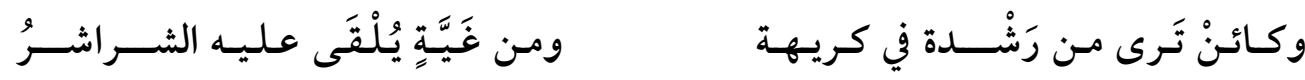
- يقول: كم رُشد لقيته فيما تكرهه وكم غَيّ فيما تحبه وتهواه"( ). - رابعاً : ومثل هذا يُقال في الآية الثانية، وذلك لأن الضَرَّ وإن كان يقابله النفع، فإن الرََََّد أعم من لن النفع، لأنه يقابل الغي والضلال معا وفي الأول مضرة الدنيا وفي الثاني مضرة الآخرة، أما كلمة

$$
\text { (النفع) فقد تعني المنح الدنيوي الذي قد يؤدي إلى المنع الأخروي. }
$$

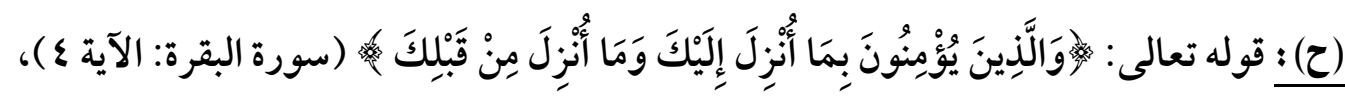
حيث عدل النص الكريم عن تحقيق المطابقة المعيارية الثكلية بين "أنزل إليك" و(أنزل إلى لي لئل غيرك) وذلك تأكيدا للقيمة المعنوية المتحققة في هذا الطباق الخلافي والمتمثلة في توثيق صفة النبي الخاتم لمحمد - صلى الله عليه وسلم - وصفة الرسالة الخاتمة لكتاب الله الكريم، لأن تعبير (غيرك) يحتمل معنى من جاء من قبل ومن بعد، لكن خاصية الإحكام والضبط في الأسلوب القر آني رجحت استخدام تعبير "من قبلك" بدلا منه.

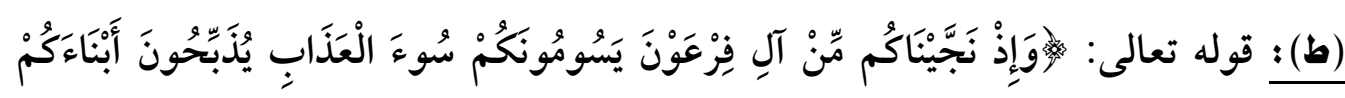

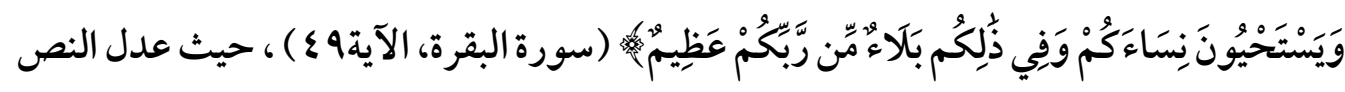
القرآني عن تحقيق الطباق القياسي المعياري بين "أبناءكم" و(بناتكم) أو بين "نساءكم" لينمي

(1) ينظر لسان العرب، المجلد الثالث، صـ. 170 


\section{6}

و(رجالكم) وذلك تأكيدا للقيم المعنوية التي تتجاوز القياس التقعيدي والمعيار الشكلي لتحقق التقل الغاية الفنية والخصوصية الأسلوبية، وذلك لأن غاية آل فرعون من استحياء البنات والاستبقاء

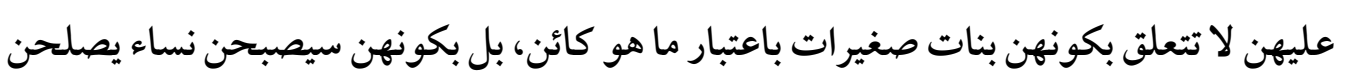

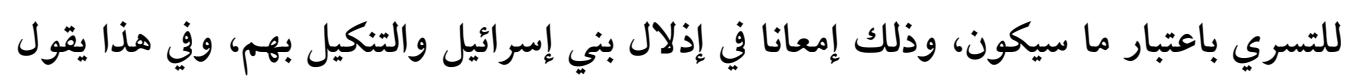
الألوسي: "وهي في الأصل البالغات دون الصغائر، فهي على الوجه الأول مجاز باعتبار الأول

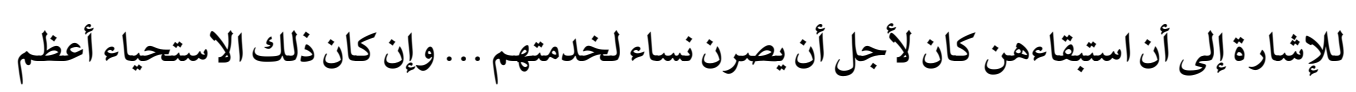

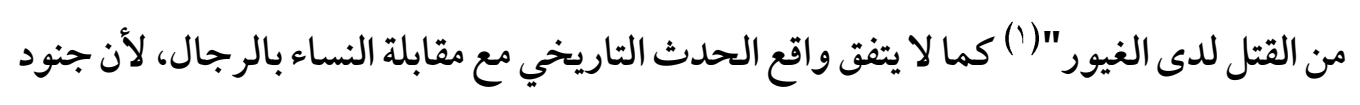

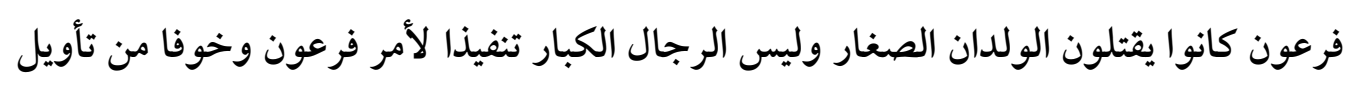

رؤياه التي تحذر من خطر الأبناء الصغار وليس الرجال الكبار (r).

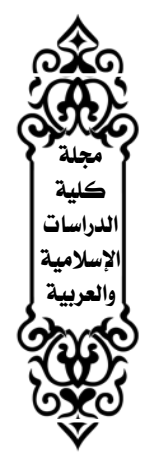

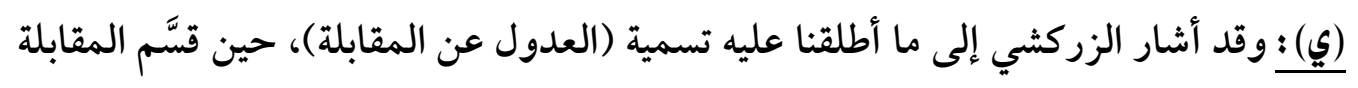

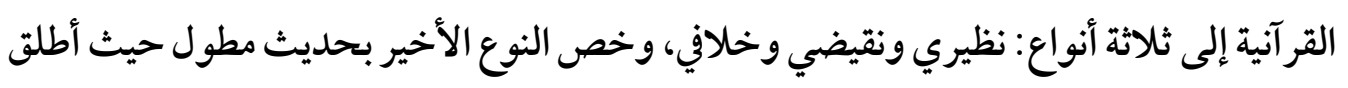

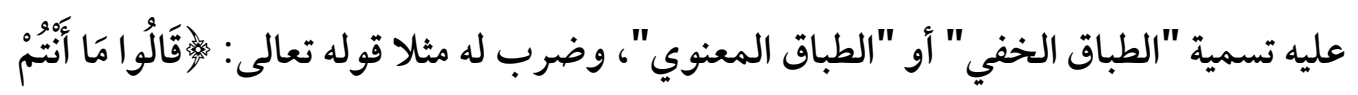

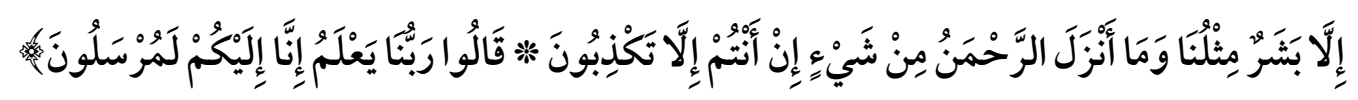

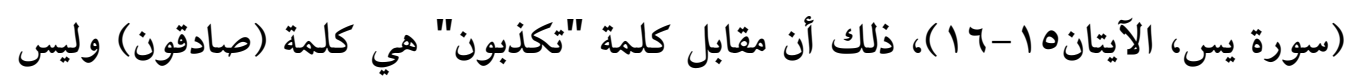

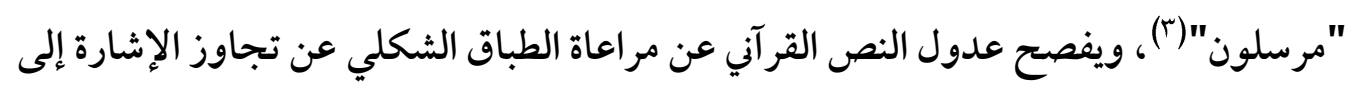
صفة الصدق بالإشارة إلى ما يؤكدها ويعضدها، وفي هذا إيجاز بلاغي مشهود يتحقق من خلال

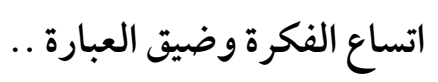

(1) "ينظر الألوسي (أبو الفضل شهاب الدين السيد محمود البغدادي)، روح المعاني في تفسير القرآن العظيم

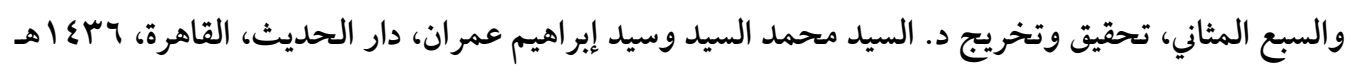

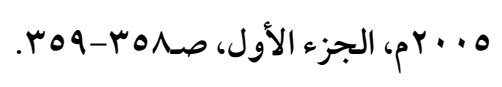

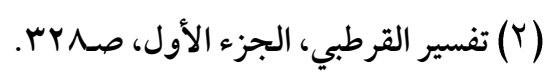

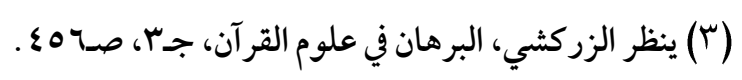




\section{فئ日}

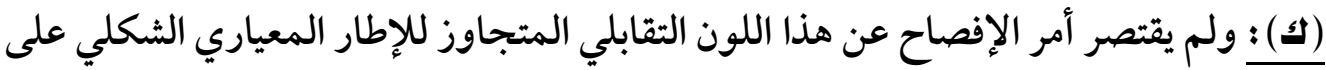
الزركشي في صكه لمصطلحي "الطباق الخفي" أو "الطباق المعنوي"، بل أدرك هذا اللون عدد التهن كبير من البلاغيين كما هو الشأن لدى حازم القرطاجني حين تناول هذا الفن في إطار ما أطلق عليه

$$
\text { (مقارنة الشيء بما يقرب من مضاده)" ( ). }
$$

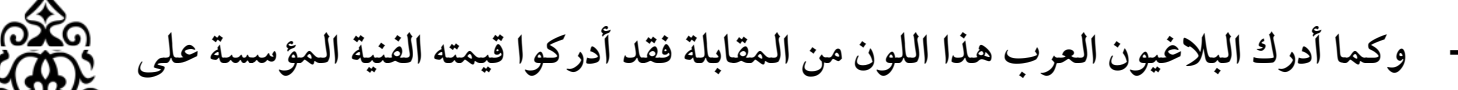

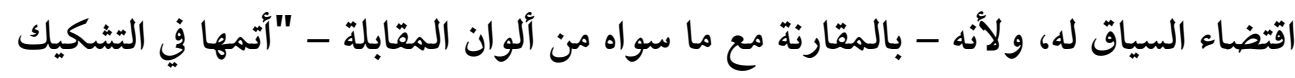

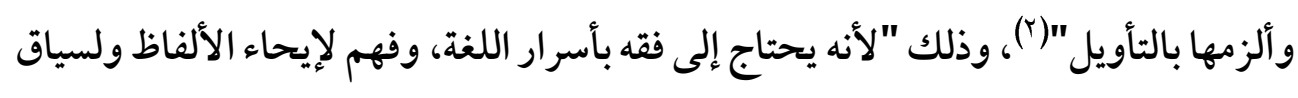

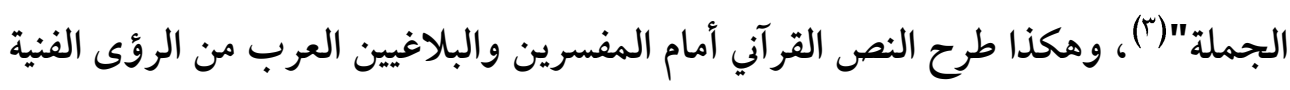
والقيم الجمالية ما مكنهم من إدراك هذا اللون الخفي من المضادة، فأدركوا جمالياته المؤسسة على تجاوز المعايير الثابتة والأقيسة الجامدة من أجل استثراف الفرائد الأسلوبية

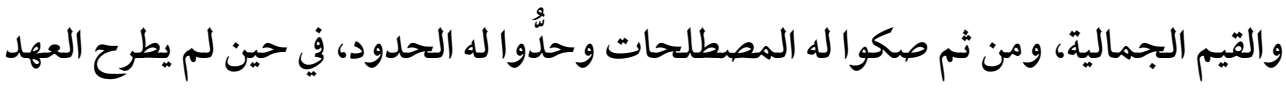

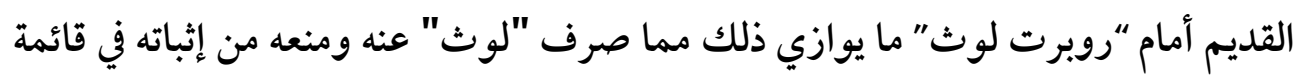
أنواع التوازي التقابلي في العهد القديم، ومن ثم وقف في دراسته للتوازي التقابلي في المفردات والعبارات التوراتية عند الرؤية المعيارية للتوازي التقابلي، وهي الرؤية التي تتعامل مع المقابلة بوصفها تعبير امحضا عن التضاد، بينما تجاوزت الدراسات القر آنية هذه المعالجات المعيارية التقعيدية، وتعاملت مع المقابلات القرآنية بوصفها مقابلات تعبر عن مفاهيم

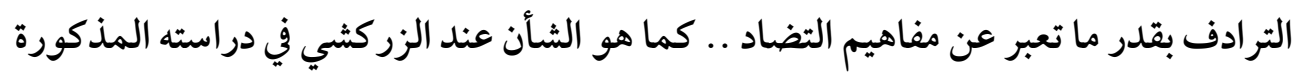
سابقا لأشكال المقابلة والمطابقة في القرآن الكريم، وعندما قسّم المقابلة القر آنية إلى ثلاثة

$$
\begin{aligned}
& \text { (1) أبو الحسن حازم القرطاجني، منهاج البلغاء، صـ9 ع. }
\end{aligned}
$$

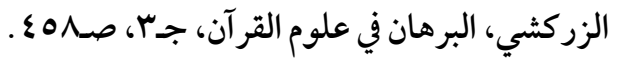

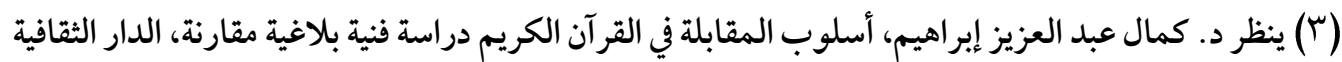

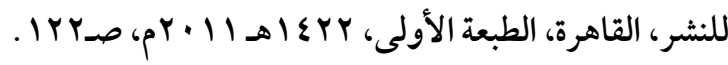




\section{主}

أنواع: نوع وحيد منها يعبر عن التضاد المحض هو الذي أطلق عليه اسم "نوع المقابلة

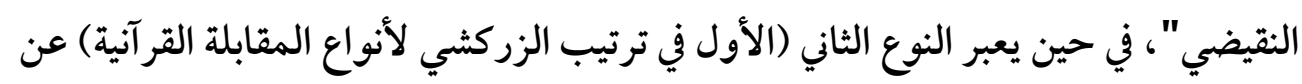

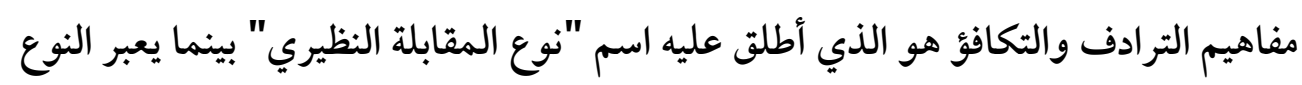

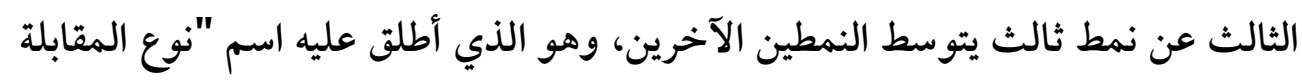
الخلافي"(")، وتتسق هذه الرؤية الجمالية من جانب الزركثي مع عطاءات الدرس الأسلوبي الحديث، حيث تطرح الدراسات الأسلوبية الإحصائية فكرة منهجية مؤداها أن التقابلات التهات المتضادة قد تنتهي إلى بنيات ترادفية بوجه من الوجوه، كما تنطوي المقابلة على (ميكانيزم

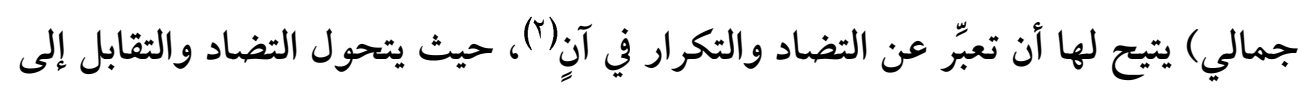
تناسب وتوازن، وذلك حين يتكرر في النص "فيتحوَّل التضاد تناسبا بالعلاقة بغيره"((). - ولعل الزركشي في هذا التوجه يتبع تيارا كبيرا متجذرا في تاريخ البلاغة العربية يربط بين

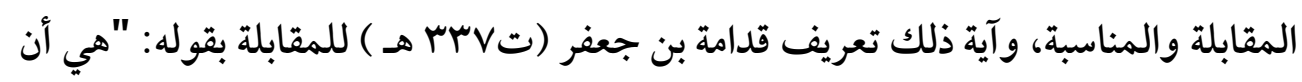

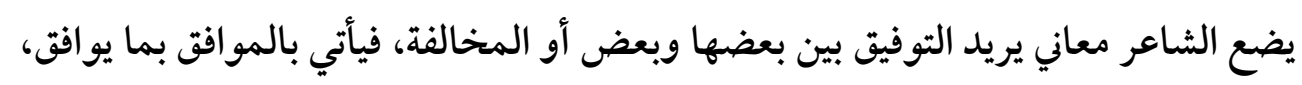

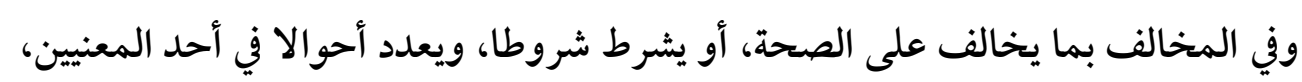

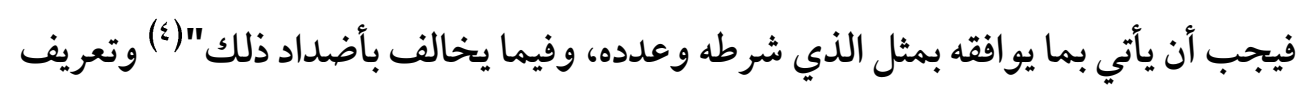

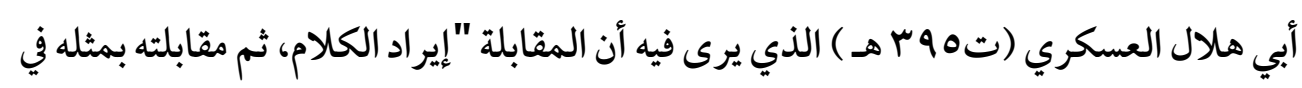

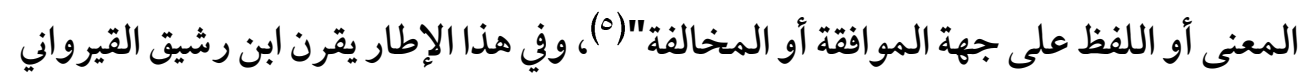

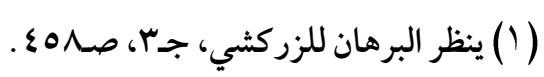

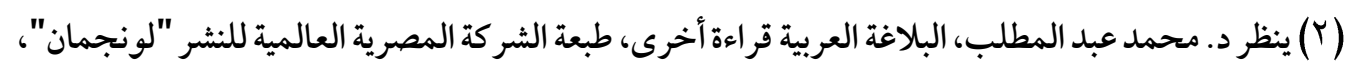

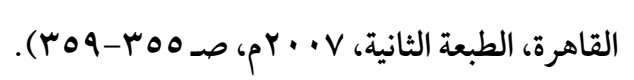

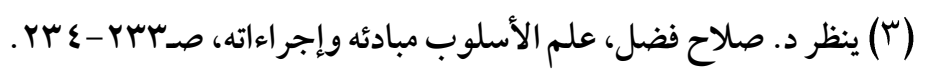

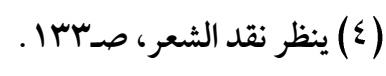$$
\text { (0) ينظر الصناعتين،صد؟ ؟r. }
$$ 
(ت ت7 ع هـ ) بين المطابقة والمساواة بناءً على التسمية التي صكها قدامة (التكافؤ)(')، وفي هذا الإطار يعرّف حازم القرطاجني (تع^ף هـ ) المقابلة فيقول: "تكون المقابلة في الكلام بالتوفيق بين المعاني التي يطابق بعضها بعضا، والجمع بين المعنيين الذين يكون بينهما نسبة تقتضي لأحدهما أن يذكر مع الآخر، من جهة ما بينهما من تباين أو تقارب، على صفة في

الوضع تلائم بها عبارة أحد المعنيين عبارة الآخر، كما لاءم كلا المعنيين في ذلك صاحبه"(()، ووفق هذا التوجه، يفرّق ابن أبي الإصبع بين الطباق والمقابلة، بأن الطباق لا يتحقق إلا في الأضداد، أما المقابلة، فتتحقق في الأضداد وغيرها(؟). - وهكذا نستطيع أن نخلص من هذا العرض التاريخي لتطور مفاهيم المقابلة في البلاغة العربية إلى حقيقة علمية مؤداها أن المقابلة لم تنحصر في التعبير عن التضاد بوصفها نقيضا للمساواة والترادف إلا في دراسات البلاغيين المتأخرين، تلك الدراسات التي اتسمت بالمنهجية المعيارية والتقعيدية وبلغت ذروتها على يدي السكاكي وتلامذته، ولعل هذه المنهجية التقعيدية المعيارية - كذلك - هي التي دفعت "روبرت لوث" إلى حصر مفاهيم المقابلة في

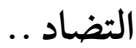

\section{- التناظرية التقابلية على مستوى السورة:}

- لم يشر “روبرت لوث” إلى تجليات التوازي التقابلي في إطار السّفر أو الأصحاح، في حين اتسعت الدراسات القر آنية لرصد مظاهر التناظرية التقابلية في إطار السورة، فكان لكل سورة قر آنية بنيتها التناظرية التي تختلف من خلالها مع غيرها من سور القر آن الكريم، وتصدَّى عدد كبير من الدارسين إلى رصد ملامح هذا النمط التناظري، كما هو الشأن لدى الإمام فخر الدين

$$
\begin{aligned}
& \text { ( (l) ينظر العمدة في محاسن الشعر وآدابه ونقده، جـr، صـ }
\end{aligned}
$$

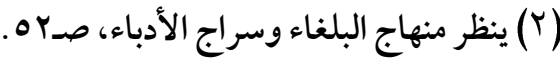

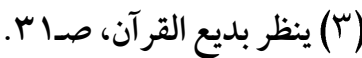




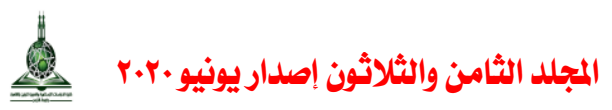

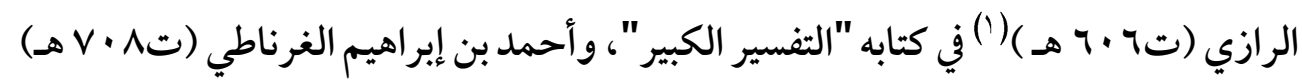

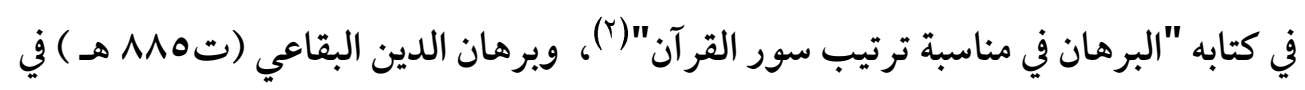

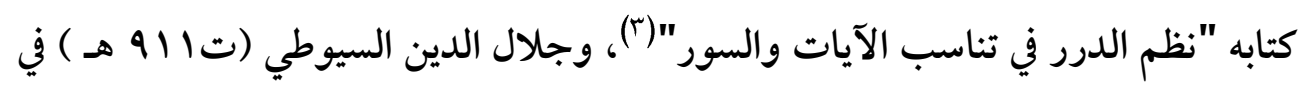

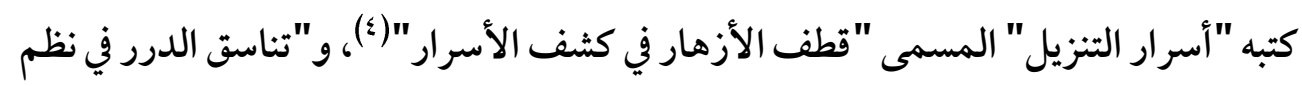

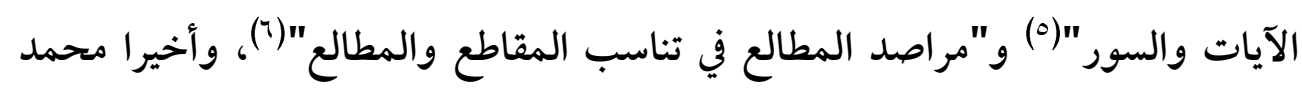

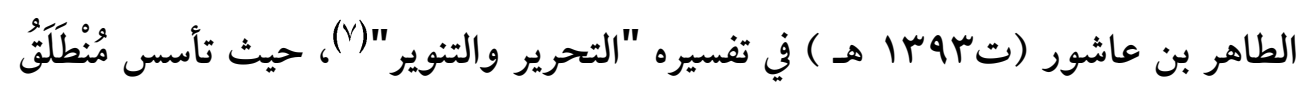

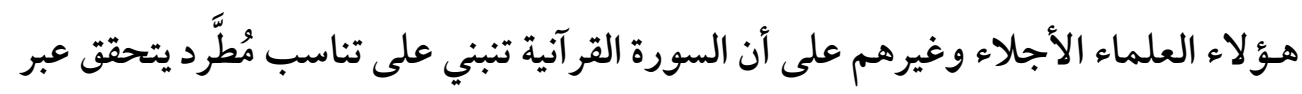

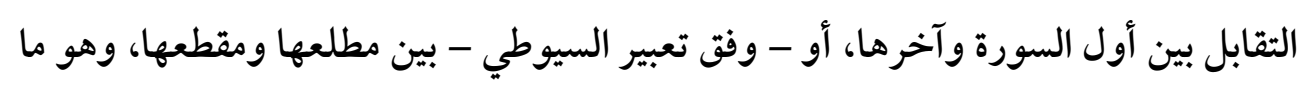

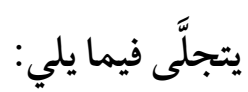

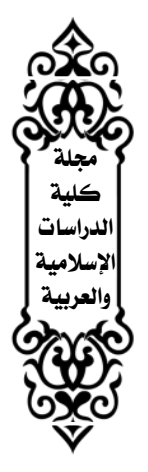

- سورة الفاتحة: بدأت بما يَذكره المقربون الحامدون، وختمت بما يُذكر عن المغضوب

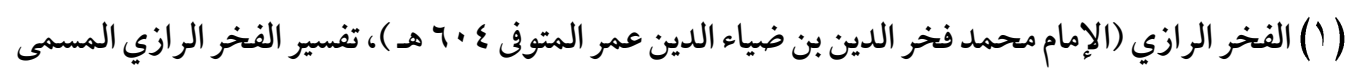

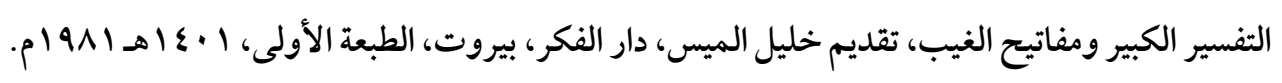

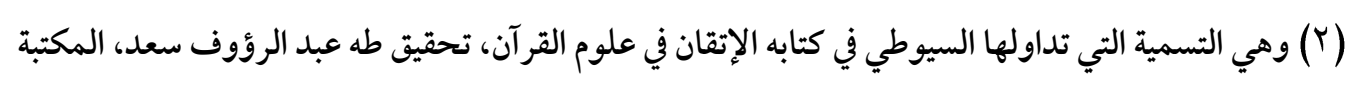

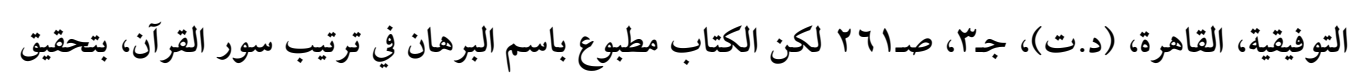

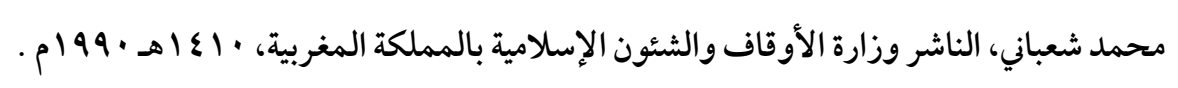

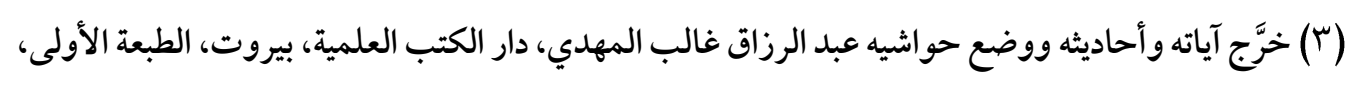
. $1 \leqslant 0$ (؛) وهو لا يزال مخطوطا، ينظر حاجي خليفة، كشف الظنون عن أسامي الكتب والفنون، تحقيق مصطفى بن

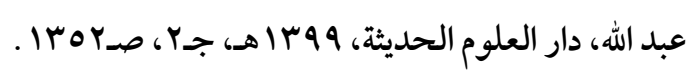

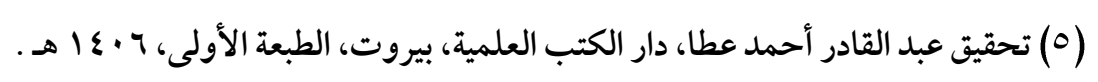

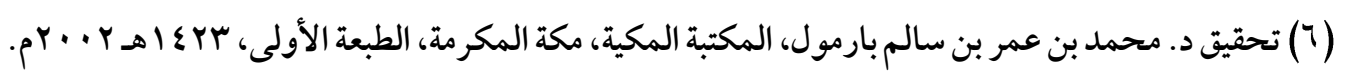

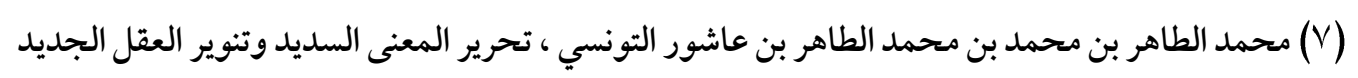

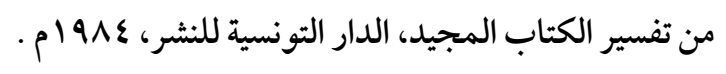




\section{فرائد البنية التناظرية في النصالقرآني (دراسل اسلوبية إحصائية مقارنة) \\ عليهم والضالين.}

- سورة البقرة: انتهت بما بدأت به من المقابلة بين المؤمنين والكافرين (') - - سورة آل عمران: افتتحت بذكر المطابقة بين القر آن والتوراة والإنجيل، واختتمت بالمطابقة بين ما أُنزل إلى أهل الكتاب وما أُنزل إلى أهل التوحيد (؟). - سورة النساء: "افتتحت بذكر بدء الخلق والولادة، وختمت بأحكام الوفاة"(r). - سورة المائدة: "في أولها إحلال بهيمة الأنعام، وفي آخرها النعي على من حرَّم منها ما لم يحرمه الله "(ఓ)

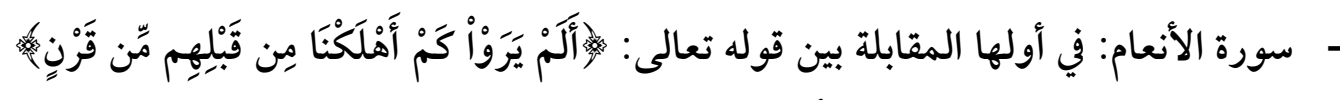

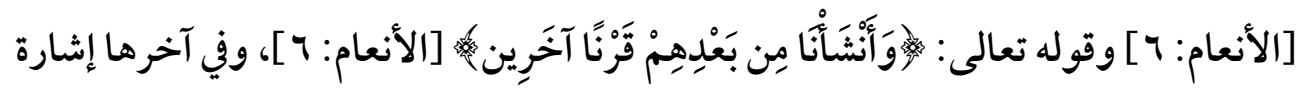

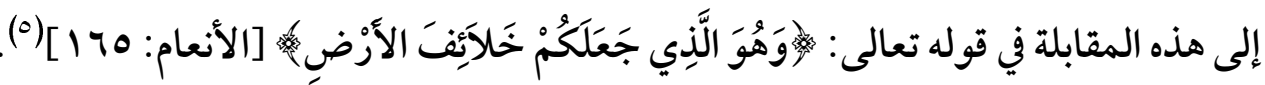
- سورة الأعراف: "في أولها وصف إبليس بالاستكبار وختمها بوصف الملائكة أنهم لا

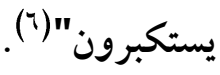

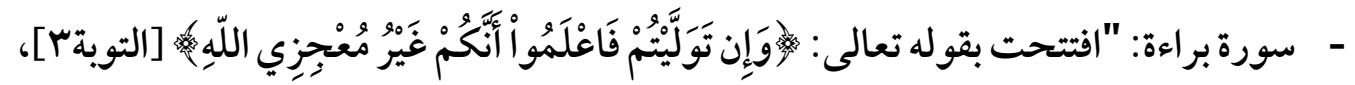

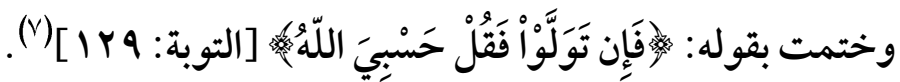

$$
\begin{aligned}
& \text { ( (1) راجع مر اصد المطالع، صـ } 1 \text {. } \\
& \text { (Y) السابق، صـVYr } \\
& \text { (ץ) السابق، صح/ }
\end{aligned}
$$

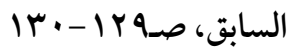

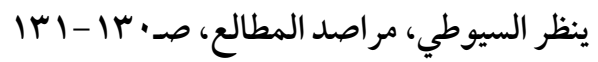

$$
\begin{aligned}
& \text { (ד) السابق، صدrr| } \\
& \text { (V) السابق، صحس (V) }
\end{aligned}
$$


- سورة النحل: "افتتحت بالنهي عن الاستعجال وختمت بالأمر بالصبر"(().

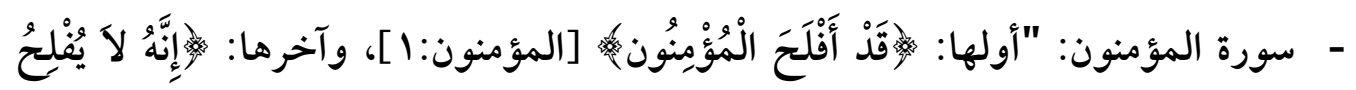

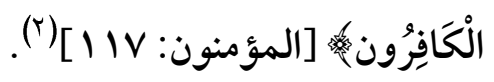

- سورة الفرقان: "بدئت بتبارك وختمت بذلك"(r)، ولكن تبارك الأولى تتعلق بالهداية الروحية في قوله تعالى : حين تتعلق تبارك الثانية بالهداية المادية في قوله تعالى:

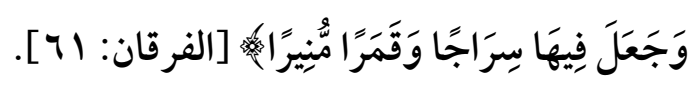

- سورة القصص: "في أولها هـرة موسى من وطنه والعودة إليه، وفي آخرها هـجرة النبي صلى الله عليه وسلم - من وطنه والعودة إليه"(؛).

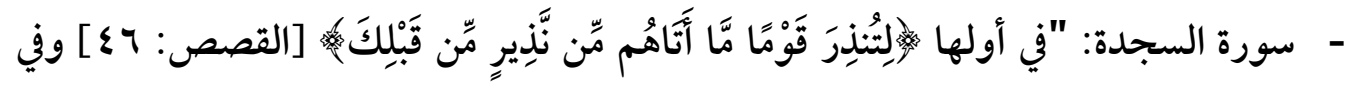

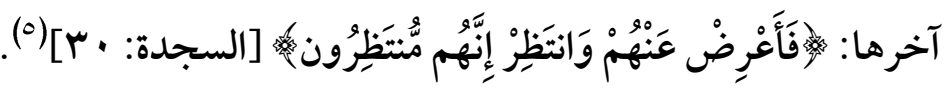

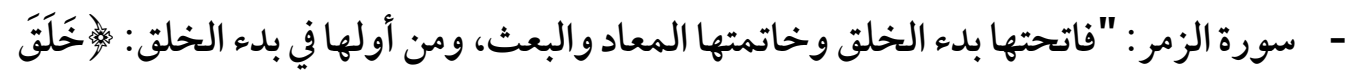

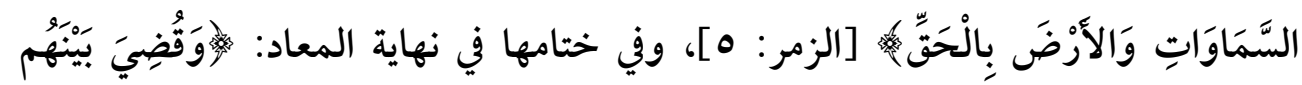

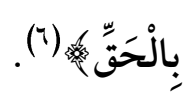

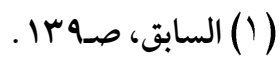

(Y) السابق، صـY \& 1، وينظر الزمخشري (أبو القاسم جار الله محمود بن عمر الخواوزمي)، الكشاف عن حقائق

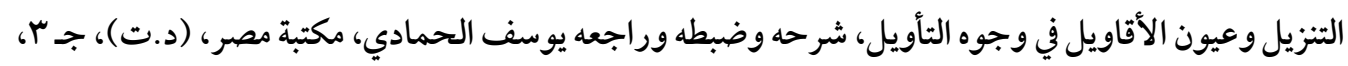

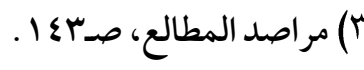

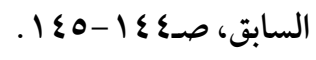

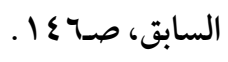

$$
\begin{aligned}
& \text { (1) السابق، ،صـ10. }
\end{aligned}
$$




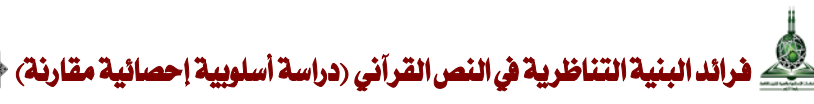

- - سورة الملك: بدأت بوصف قدرة الله وانتهت بوصف عجز الناس ('). - سورة الإنسان: "بدئت بذكر الشاكر والكفور وختمت به"(ץ).

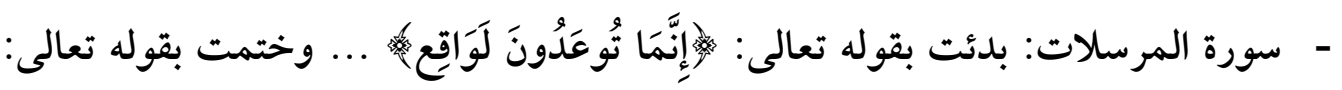

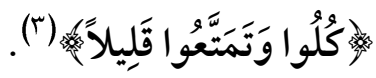

- سورة عبس: بدئت بقوله تعالى:

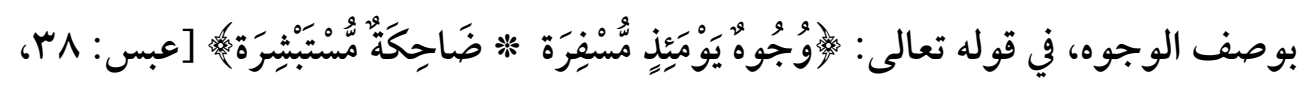
(₹) $[\mathrm{rq}$ - سورة الليل: بدئت بذكر معالم الدنيا وسعي الإنسان فيها، وختمت بذكر معالم الآخرة من الجنة والنار.

- سورة القدر: "بدئت بذكر الليلة وختمت بمطلع الفجر"(•). - سورة العاديات: بدأت بحال العبد الجَحود الكفور، وختمت بحال الرب الذي هو بعباده

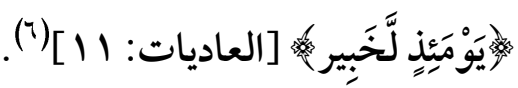

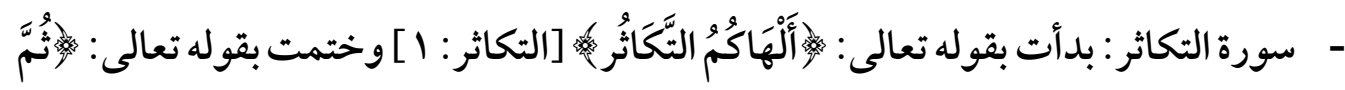

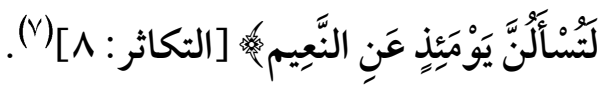

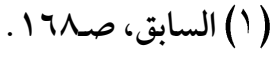

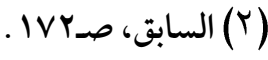

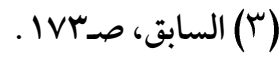

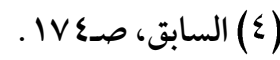

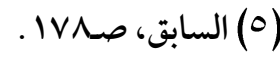

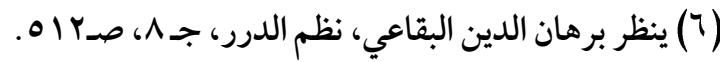

$$
\begin{aligned}
& \text { IV9 مر اصد المطالع، صد (V) }
\end{aligned}
$$


- سورة العصر: أولها ذكر خسران الإنسان في عمومه، وآخرها ذكر استثناء المؤمنين بما قدموا

من تواصِ بالحق و الصبر (').

سورة الكوثر : بدأت بما أعطى الله نبيه، وختمت بما قطع الله شانئه(؟).

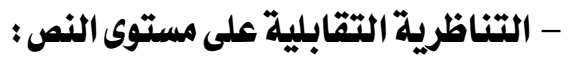
- علاقات التقابل ومعدلات التكرار: توقفت نظرية التوازي في النص التوراتي - من خلال دراسات روبرت لوث - عند مستوى الكلمتين والعبارتين، لكنها تعدت ذلك في الدراسات القرآنية لتشمل التوازي/ التناظر على مستوى السورة كما مرَّ طرحه في النقطة السابقة، ثم اتسعت على وجه أكبر لتشمل التوازي/التناظر على مستوى النص القرآني كله، وهو الوجه الذي ستتناوله الدراسة في الصفحات التالية .. وتتحقق التناظرية التقابلية على مستوى النص من خلال التضاد الذي يقع بين الكلمات المتقابلة في مجمل هذا النص، وهو الأمر الذي تتولى إجراءات المنهج الأسلوبي الإحصائي

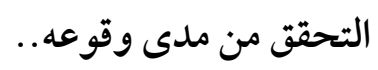

وفي هذا السياق يذكر الأسلوبيون الإحصائيون أن "نقطة الانطلاق العملية لتحليل الأسلوب هي اختيار معدلات التكرار للعناصر اللغوية في سياقات مختلفة تربطها علاقة ما"(")، وتعبِّر معدلات التكرار في النص القرآني عن سمات تفرُّدِ هذا النص إذا ما وُضِعَ في إطار الدراسة المقارنة مع غيره من النصوص الدينية، حيث ينطوي التوازي في نواتج القياس الكمّي Quantitive Measurment

$$
\begin{aligned}
& \text { (1) نظم الدرر، جـم ،صـع به. } \\
& \text { (r) السابق، صده } 0 \text {. }
\end{aligned}
$$

(r) د. صلاح فضل، علم الأسلوب مبادئه وإجر اءاته، صـ9 ؟ ؟، وينظر د. سعد مصلوح، الأسلوب دراسة لغوية إحصائية، صـه-هN. 
المعدلات الإحصائية في تجلياتها التقابلية.

وعلاقات التقابل في الدرس الأسلوبي الإحصائي - بوجه عام - دائما ما تمثّل - على حد

قول ميشيل ريفاتير Michael Riffaterre - متغير امهما في سبيل اكتشاف البنية الأسلوبية

للنص الخاضع للدراسة الإحصائية (').

وبتطبيق هذا الإجر اء المنهجي على النص القر آني يتضح أن البنية القر آنية قد تأسست على

نسق تناظري شديد الوضوح، وقد وضع الدارسون المشتغلون بعدّ ألفاظ القر آن الكريم أيديهم م كُملية

Frequency على نتائج شديدة الأهمية في إطار ما نحن بصدده من دراسة معدلات التكرار وآليات التقابل Antibiosis في مجمل النص الكريم، من مثل أن طباقا كالذي يقع في ثنائية "الدنيا والآخرة" لا يتحقق - فقط - في إطار الجملة الواحدة، كما في قوله تعالى: لوَوَابْتَغ فِيمَا

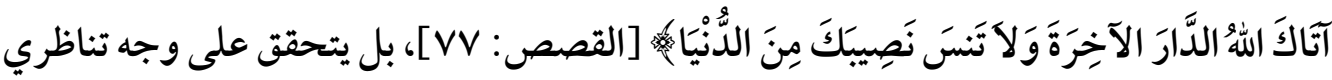
شديد الإحكام في مجمل آيات الكتاب الكريم، حيث تتكرر مفردة الدنيا في كتاب الله مائة وخمس عشرة مرة، وهو ذاته العدد الذي وردت فيه كلمة الآخرة، رغم أن كلمة الآخرة جاءت منفردة في

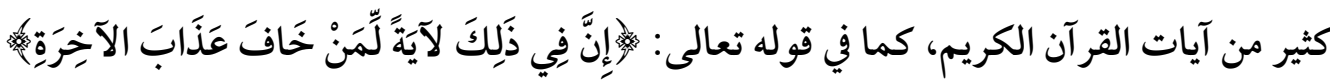
[هود: r • 1]، وكلمة الدنيا - بالمثل - جاءت منفردة في كثير من الآيات الأخرى، كما في قوله

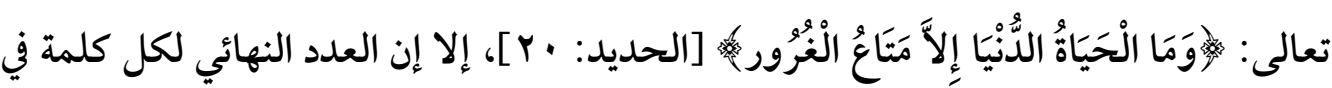
النص الكريم يناظر العدد النهائي للكلمة الأخرى .. ويتكرر هذا التناظر في عدد الكلمات المتقابلة في ثنائية "الشياطين والملائكة"، حيث

(1)Michael Riffaterre, Essais de stylistique structurale, Flammarion, 1971. shorturl.at/1GM, P2 وينظر د. صلاح فضل، الأسلوب مبادئه وإجر اءاته، صدابr. 
يتكرر كل قسيم منهما ثمانيا وستين مرة( (1). وينفرد النص القر آني بهذه الظاهرة، فلا ينبئ عدد المرات التي تكرر من خلالها لفظا الدنيا والآخرة أو الملائكة والشياطين عن أية دلالة في نص التوراة - على سبيل المقارنة - فيما نحن بصدده من دراسة البنية التناظرية في كلمات النص، وفي هذا السياق تتجلَّى إحدى أبرز ثمرات الدرس الإحصائي "في قدرته على التمييز بين السمات أو الخصائص اللغوية التي يمكن اعتبارها خواص أسلوبية وبين السمات التي ترد في النصوص عشوائيا"(r)، ففيما يتعلق بثنائية الدنيا والآخرة وبعد إحصاء عدد مرات ورود كل من طرفيها في العهد القديم(ّ). تبين أن مفردة (الدنيا) قد تكررت مرتين اثنتين فقط على الوجه التالي: -

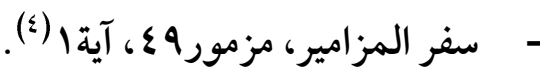

( (1) يُعزى هذالجهد في الكشف عن هذه التماثلات العددية إلى د. عبد الرزاق نوفل في كتابه "الإعجاز العددي

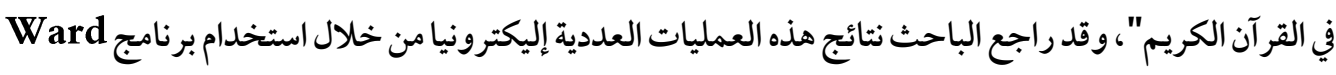

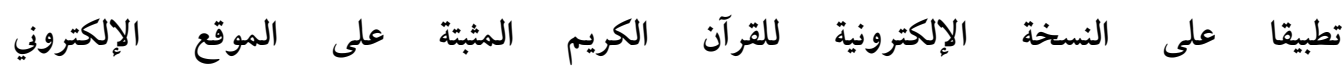
(http://www.a7bash.com/book.php?action=showbook\&id=60) (ذبع حيث تم توثيق العدد

$$
\text { الأكبر من التتائج وتغيير نذر يسير منها، وهو ما سيلي ذكره في حينه . }
$$

(r) اعتمد الباحث في إجر اء الدراسات الإحصائية في العهد القديم على طبعة الكتاب المقدس التي أصدرتها

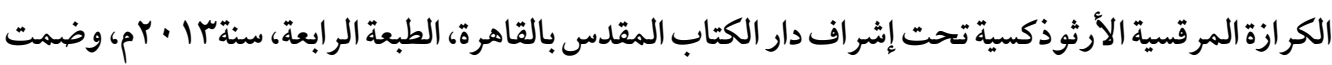
تسعة وثلاثين سفرا، وهي تختلف عن النص الكاثوليكي الذي يضيف سبعة أسفار أخرى ليصل عدد أسفار

$$
\text { التوراة لديه إلى ستة وأربعين سفرا. }
$$$$
\text { وهنالك مرتان أخريان في الأسفار السبعة الزائدة في التوراة الكاثوليكية، كما يلي: }
$$

سفر يشوع بن سيراخ، الإصحاح بrv، آيةا

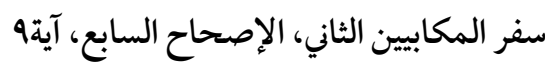


في حين خلا العهد القديم - تماما - من ذكر مفردة الآخرة أو مترادفاتها مثل القيامة أو

$$
\text { البعث أو النشور أو يوم الحساب( (). }
$$

وإذا أردنا تحديد السمات الأسلوبية للمؤلف عن طريق تحديد معدلات التكرار لمفردات بعينها عبر تطبيق الآلية التي رسخها "زمب" (Zemp) وصك لها مصطلحا هو "Stylometrie" الأسلوبي)(r) أو (القياس الأسلوبي)(r) على اختلاف هذه الظاهرة العددية بين النصين التوراتي والقرآي، فسوف تفصح هذه الآلية عن دلالات خلو النص التوراتي من أية إشارة إلى اليوم الآخر أو أي من متر ادفاته على مدى انحياز كاتب النص ضد كل ما يتعلَّق بالحياة الأخرى - على الرغم من أن النص يحمل رسالة دينية أخروية وليس رسالة نفعية دنيوية - أو هـذذا ما كان ينبغي أن يكون -

وتمتد ظاهرة الاطراد المستمر في تحقيق هذه البنية التناظرية في المفردات المتقابلة في النص القرآني، كما هي الحال في ثنائية "الصالحات والسيئات"، إذ يتكرر كل قسيم بواقع مائة وسبع وستين مرة، وبالمثل يحدث هذا التكرار المتطابق في ثنائية "الحر والبرد"، حيث يتكرر كلٌ من طرفي الثنائية بواقع أربع مرات، وهو ما يقع - كذلك - في ثنائية "حياة الإنسان وموته"،

( (1) ورد ذكر بعض هذه المتر ادفات في الأسفار السبعة المستحدثة في النسخة الكاثوليكية على الوجه التالي:

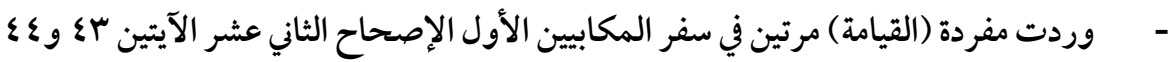

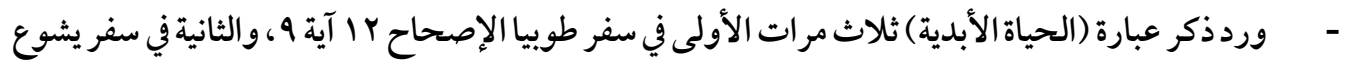

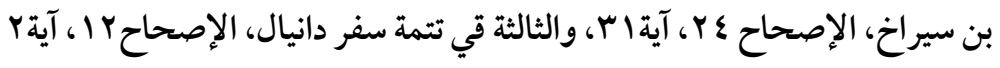
ورد التركيب الإضافي "يوم الحساب" لمرة وحيدة في الأسفار المستحدثة في النسخة الكاثوليكية في سفر الحكمة

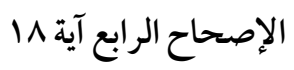

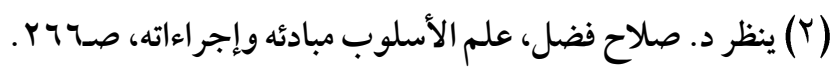

وفق ترجمة د. محمود جاد الرب لكتاب برند شبلنر علم اللغة والدراسات الأدبية، صـ ـ 1 . 


\section{الإجلد الثامن والثلاثون إصدار يونيو.r.r.}

عبر اشتقاقاتها المختلفة، حيث تتكرر كل واحدة خمسا وأربعين ومائة مرة، كما يتحقق التناظر ذاته في ثنائية "النفع والفساد" وما يلحق بها من مشتقات، ليتكرر كل طرف من طرفي الثنائية بما

$$
\text { يعادل تكرار الطرف الثاني بواقع خمسين مرة. }
$$

وهنالك ملمح مهم ينفي عن هذا التناظر العددي فرضية المصادفة، حيث لا تتحقق

التناظرية العددية من خلال العد الآلي للمشتقات التي تنتمي لجذر معجمي أو صرفي واحد، إلا إذا عبَّرت هذه المشتقات عن المحتوى الدلالي الذي يحقق المقابلة، وهو مايتجلَّلى واضحا في كل الثنائيات المتضادة دون استثناء، وآية ذلك أن ثنائية "الدنيا والآخرة" حين توازى طرفاها في عدد مائة وخمس عشرة مرة لم تشمل هذه القسمة المتناظرة المشتقات التي لا تعبر عن المفهوم

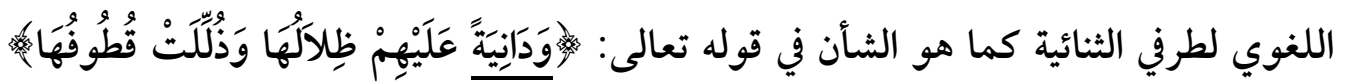

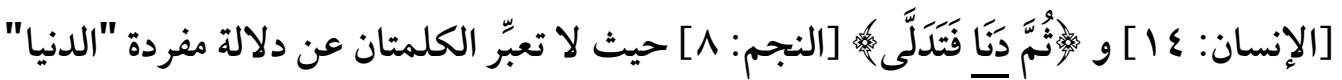

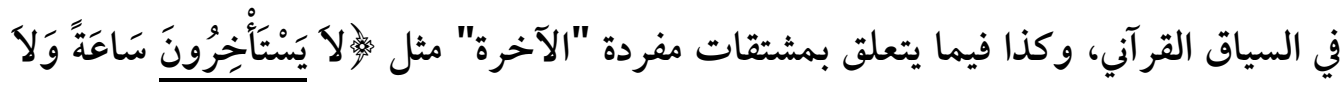

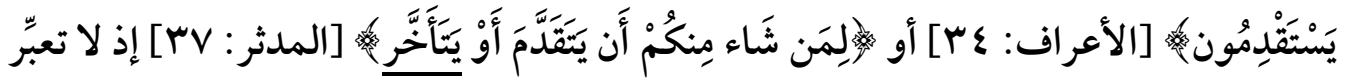

$$
\text { - أيضا - عن الدلالة السياقية لكلمة "الآخرة". }
$$

وفيما يلي بيانات تفصيلية لأمثلة من هذه الثنائيات القر آنية المشار إليها وغيرها في مقابل

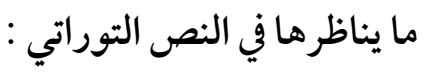


- أولا : ثنائية الدنيا والآخرة:

\begin{tabular}{|c|c|}
\hline رة): VI-الآيات: & 1) \\
\hline 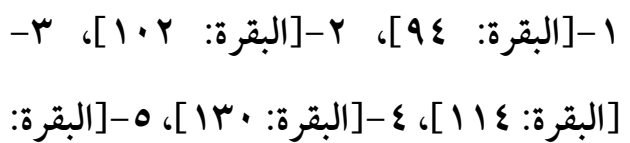 & 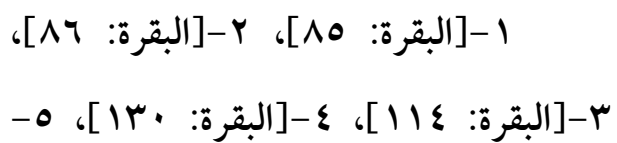 \\
\hline 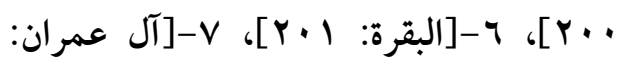 & 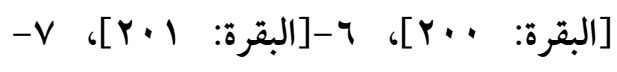 \\
\hline 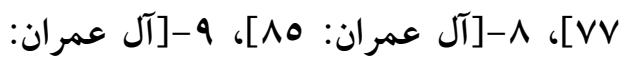 & 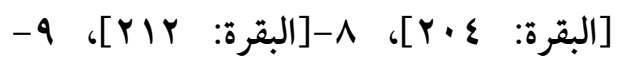 \\
\hline 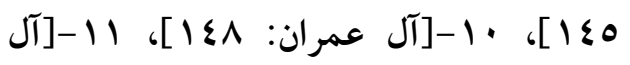 & ة: \\
\hline$-1 \mu_{6}[\operatorname{lv} 7:$ & عI]، \\
\hline [المائدة: 0]، ع 1-[المائدة: سب]، 10- & ان: : \\
\hline 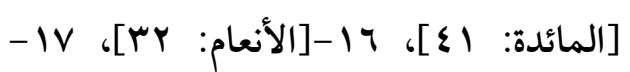 & آل عمران: IIV]، 1 آ_آل عمران: \\
\hline 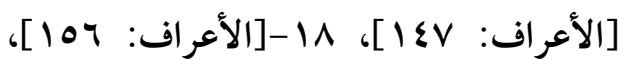 & 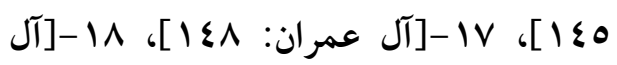 \\
\hline • عراف: 179] & 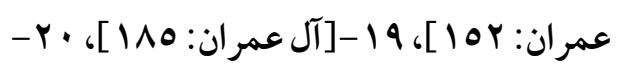 \\
\hline 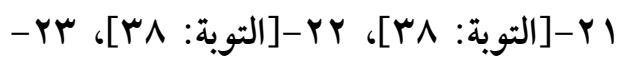 & \\
\hline 每 & T\& \\
\hline 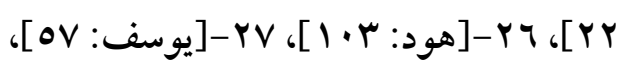 & : \\
\hline سف: 1.9]، وצ-[الرعد: YY]، & 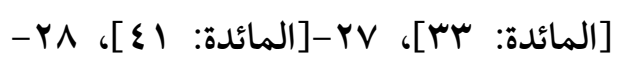 \\
\hline عد: عץ]، اس-[إبراهيم: r]، ץ"- & 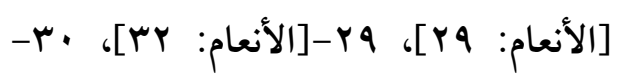 \\
\hline 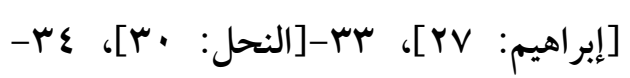 & 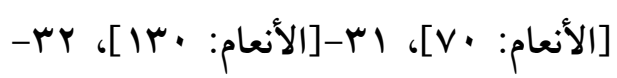 \\
\hline 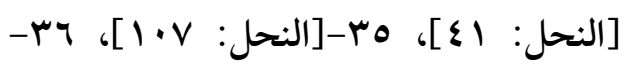 & ]: بrس]، سب-[الأعر \\
\hline 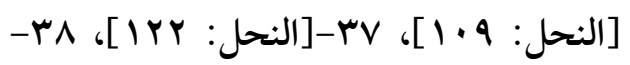 & 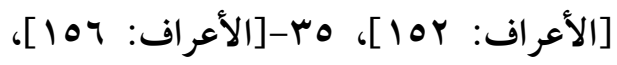 \\
\hline راء: V]، 9 ه-[الإسراء: 19]، . ع- & 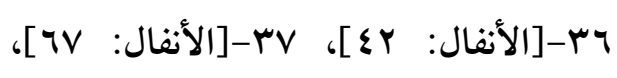 \\
\hline 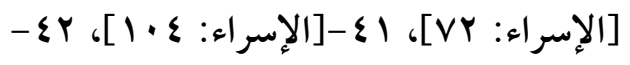 & [التوبة: ^^]، هץ-[التوبة: ^ץ]، • ع- \\
\hline 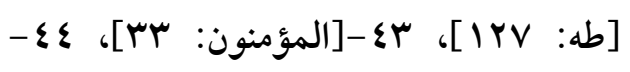 & 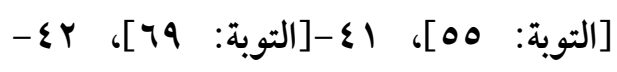 \\
\hline 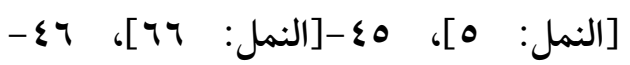 & \\
\hline
\end{tabular}




\section{الئجلد الثامن والثلاثون إصداريونيو.r.r. r.}

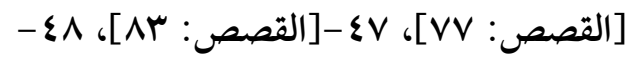

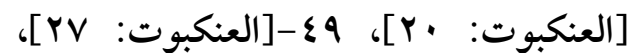
• 0 .

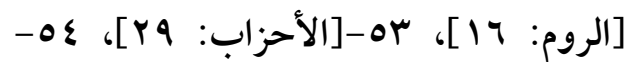

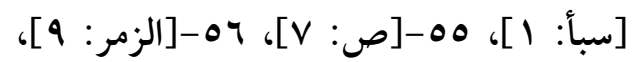
، OV [غافر:

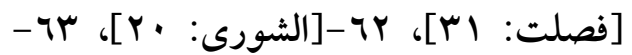

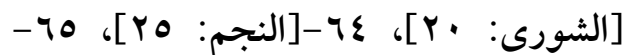

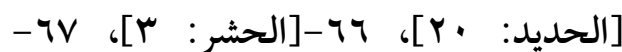

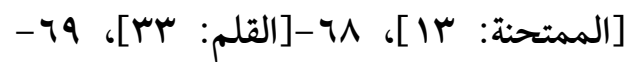

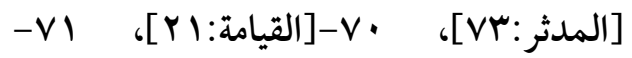
[النازعات: مץ ] (والآخرة) 9 1 - الآيات:

I-

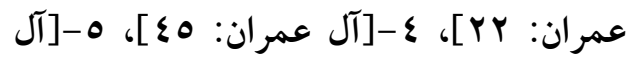

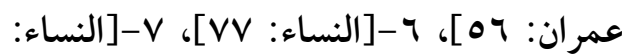
ع •|-[يوسف: 1.1]، 11-1الحج: 11]،

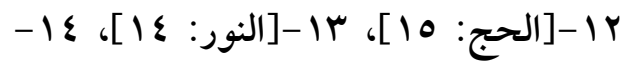

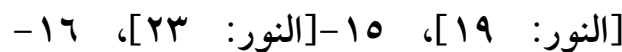
[القصص: · V]، V - IV] [الزخرف: مب]]، 9 - [الأعلى: IV]. : (بالآخرة) الب-الآية:

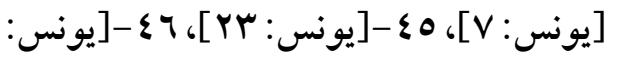
§

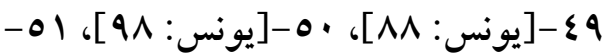

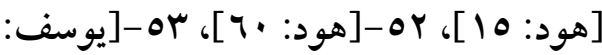

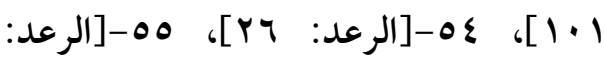

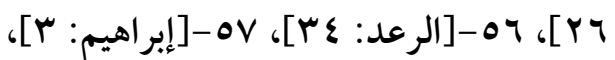
^ه [إبراهيم: • . [النحل: YT-[النحل: §-1الكهف:

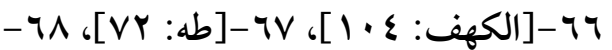
[طه: | | 11

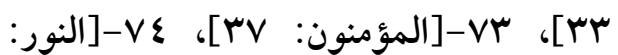

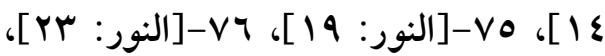
 V9-V9

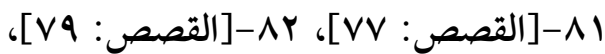

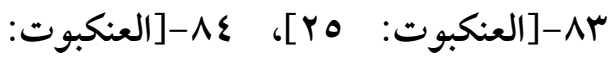

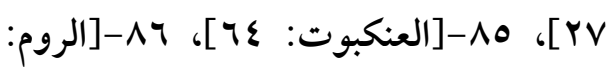
[V 9 1' [الزمر: · 1]]، ؟9-[الزمر: צr]، 90 


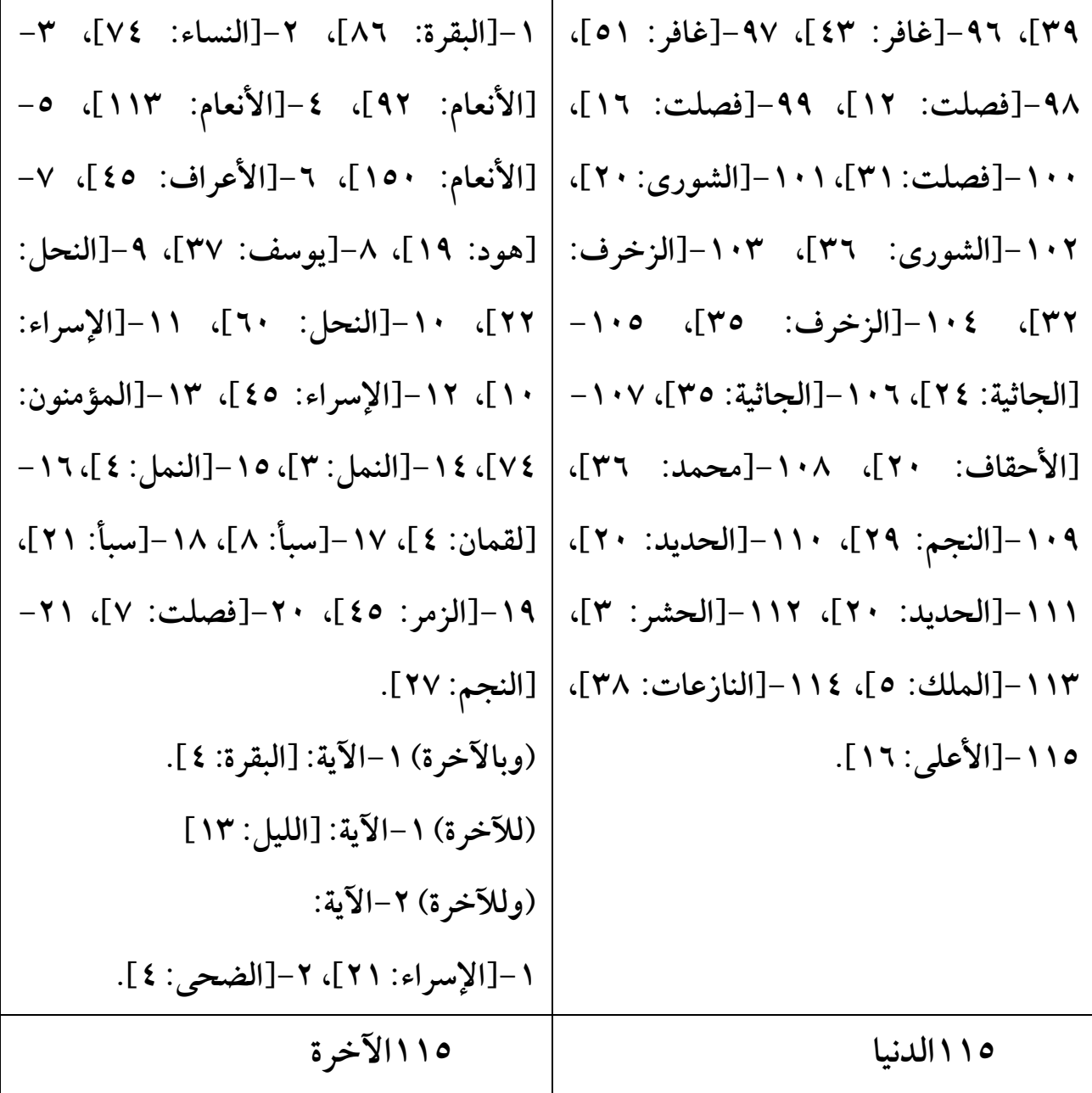

- ثانيا : ثنائية "الشياطيز والملائكة" :

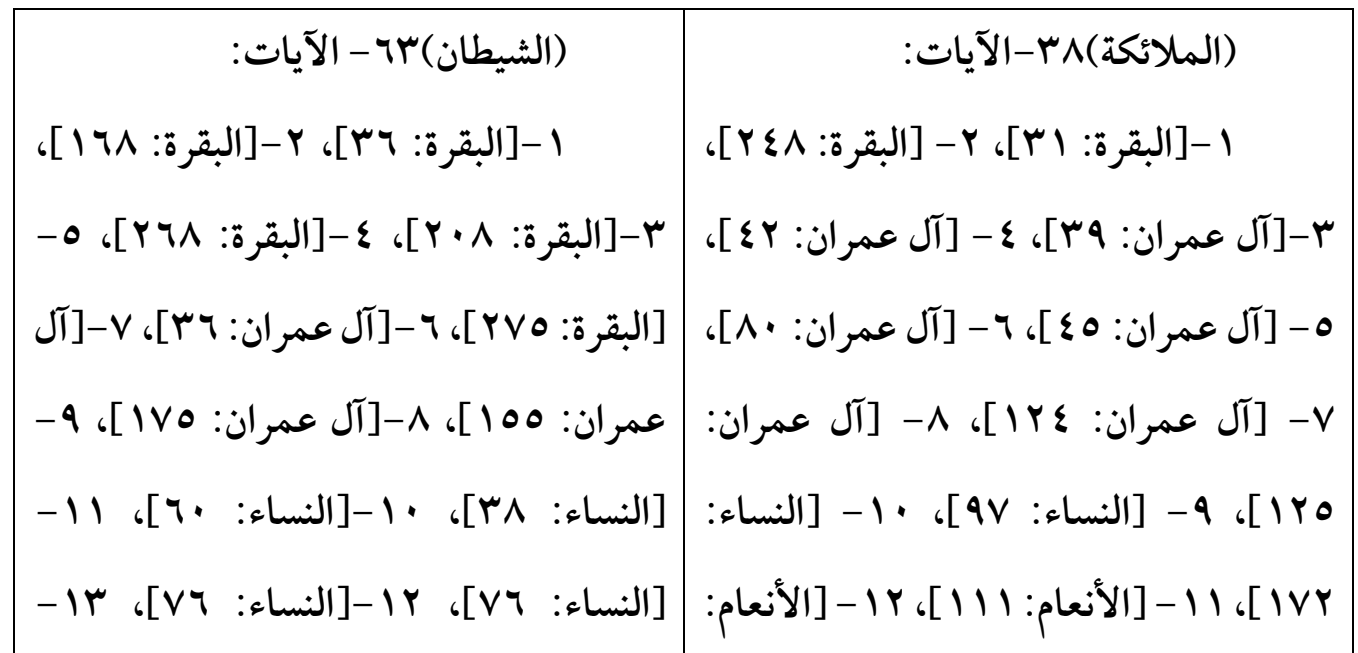


[النساء: rی]]، \&

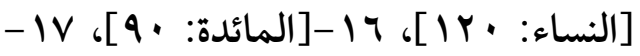

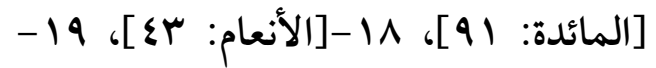

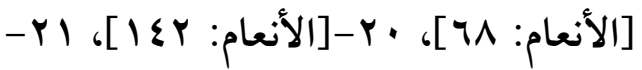

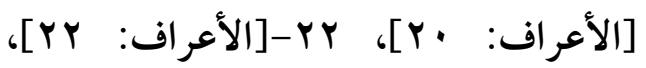

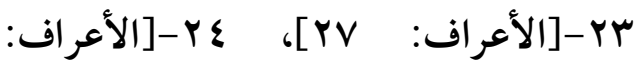
[IVO] [الأعراف: 1.r+r]،

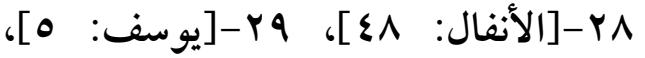
•

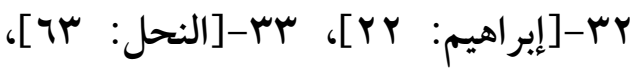

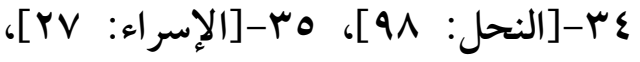
דr-[الإسراء: به]، V ^ץ-[الإسراء: \&7]، هץ-[الكهف: سד]، • •

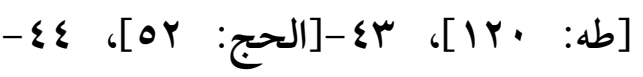

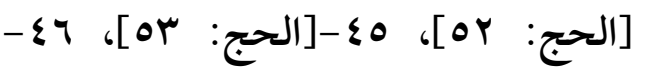
[النور:

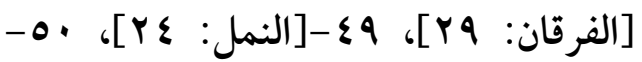

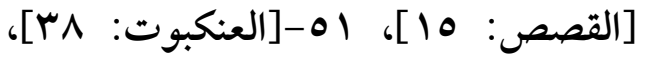


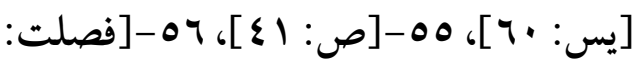

101]، r| - [الأنفال: 9]، ع - [ [الأنفال: 1Y]، 10 - [الأنفال: •0]، 1 - [الحجر:

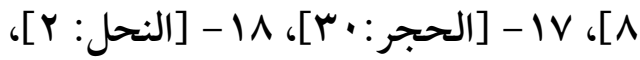
19- [النحل: ا الY- [النحل: سr]]،

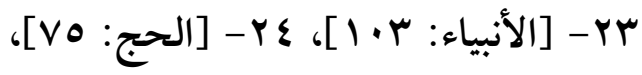
ه •- [الحج: 

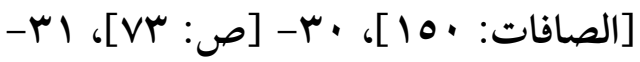
[الزمر: V0]، r [الزخرف: 19]، ع ع- [الزخرف: به]، ه

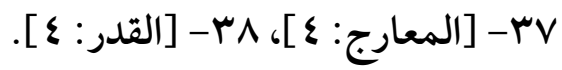
(والملائكة) ؟ ا - الآيات:

1-1البقرة:

[IVV

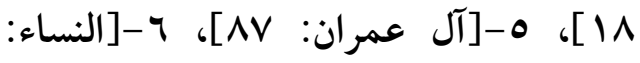

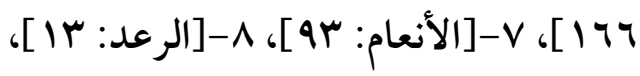
9-[الرعد: rr]، • 1-[النحل:

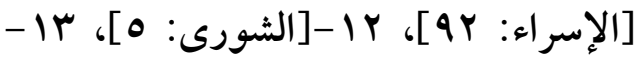
[التحريم: ؟]، ع ا-[النبأ: ^^]. (للملائكة) 9-الآيات: - (ل) 


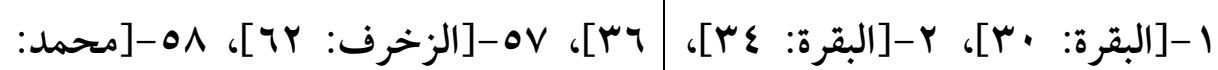

r-[الأعراف: 11]، ع-[الحجر:

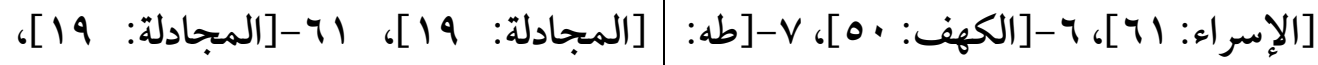

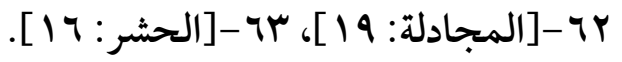

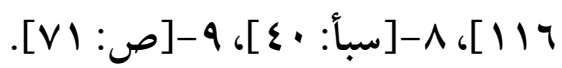

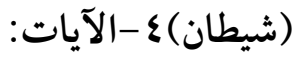

(ملائكة) (- (الآيات:

1-1الحجر: IV

1- الإسراء:

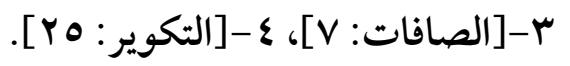

צ

(للشيطان) ا -الآيات: [مريم: 0؟ ].

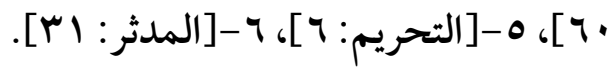

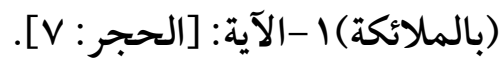

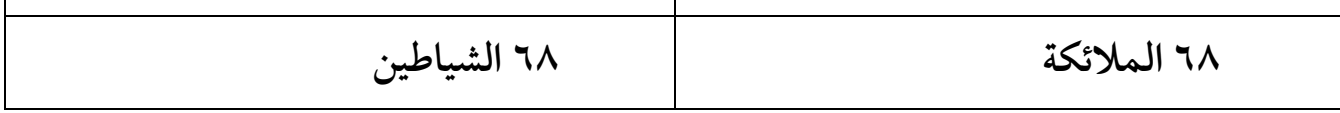

- ثالثا : ثنائية" "النفع والفساد":

\begin{tabular}{|c|c|}
\hline (المفسدين) · ا -الآيات: & (نفعا) 9- الآيات:.|' \\
\hline 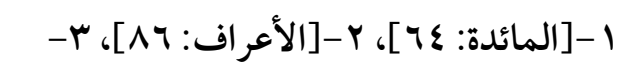 & 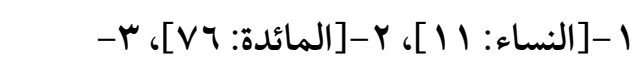 \\
\hline 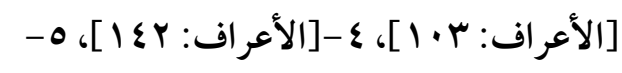 & 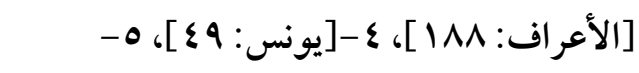 \\
\hline [يونس: 1^]، ج-[يونس: 19]]، V-[النمل: & 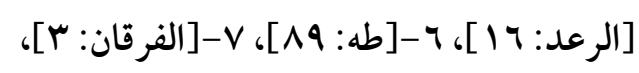 \\
\hline 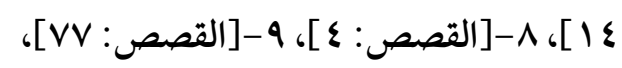 & ^-[سبأ: ץ \&]، 9-[الفتح: 11]]. \\
\hline • & (منافع) هـ - الآيات: \\
\hline (بالمفسدين) Y-الآيات: & 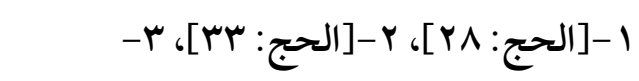 \\
\hline 1-[آل عمران: سج]، צ-[يونس: · ع]. & 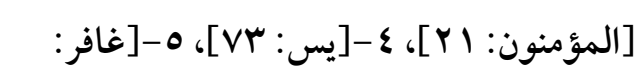 \\
\hline (كالمفسدين) ا -الآية: [ص: Y^]. &.$[\Lambda \cdot$ \\
\hline 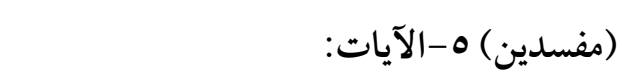 & 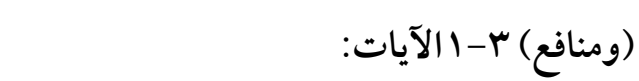 \\
\hline 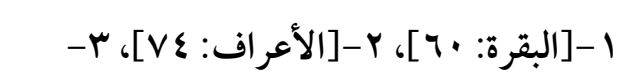 & 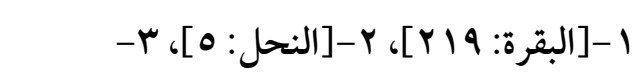 \\
\hline [هود: 01/]، ع [الشعراء: سم|]]، 0- & 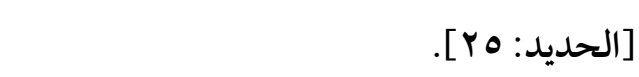 \\
\hline
\end{tabular}


المجلد الثامن والثلاثون إصدار يونيو.r.r

$$
\text { [العنكبوت: דr]]. }
$$

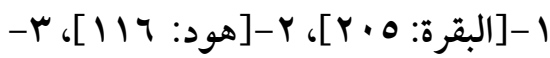

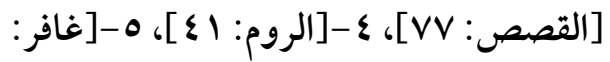

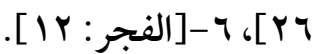
(فساد) ا-الآية:-[المائدة: بr].

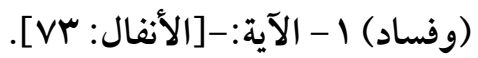

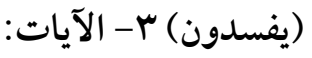

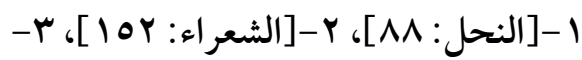
[النمل: \& ] ].

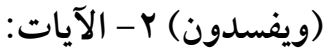
1(تفسدوا) ع - الآيات:

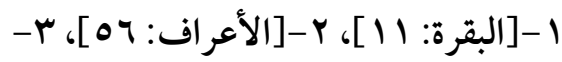

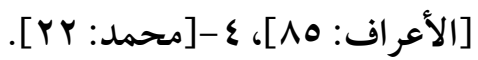
(فسادا) r- الآيات:

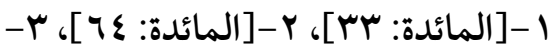

$$
\text { [القصص: rی1]. }
$$

1-[البقرة: (ليفسد) ا - الآية:-[البقرة: ه•r]

$$
\text { (يفسد) ا-الآية:-[البقرة: · ·r]. }
$$

(المفسدون) ا-الآية:-[البقرة: Y I]. (مفسدون) ا-الآية:-[الكهف: ؟9].

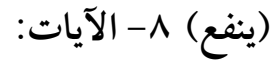

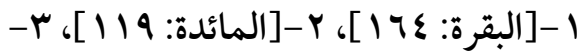

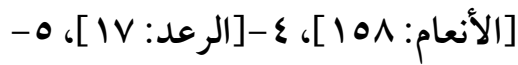

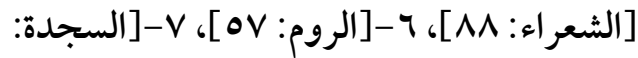

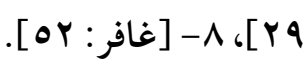
(ينفعمم) ؟ - الآيات:

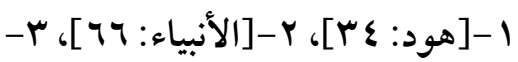

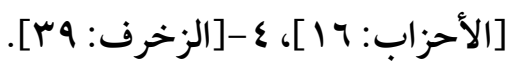
(ينفعهم) ع - الآيات:

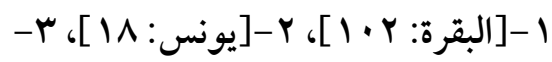
[الفرقان: 00]، ع-[غافر: 110].

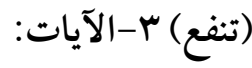
1-[طه: 9 ·1]، צ-[سبأ: سץ]، r- [الذاريات: . [00

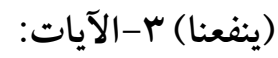

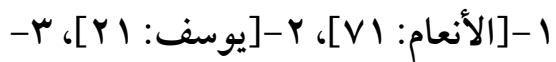
[القصص: 9] (نفعت) ا-الآية:-[الأعلى: 9].

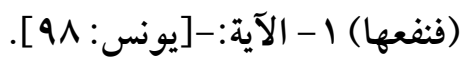
(تنفعكم) ا-الآية ا-[الممتحنة: r]]. (فتنفعه ) ا - الآية:-[عبس: ع ]. (تنفعها) ا - الآية:-[البقرة: سץ|] (تنفعهم) ا - الآية:-[المدثر: ^^] ]. (ينفعك) ا - الآية:-[يونس: T -1]]. 


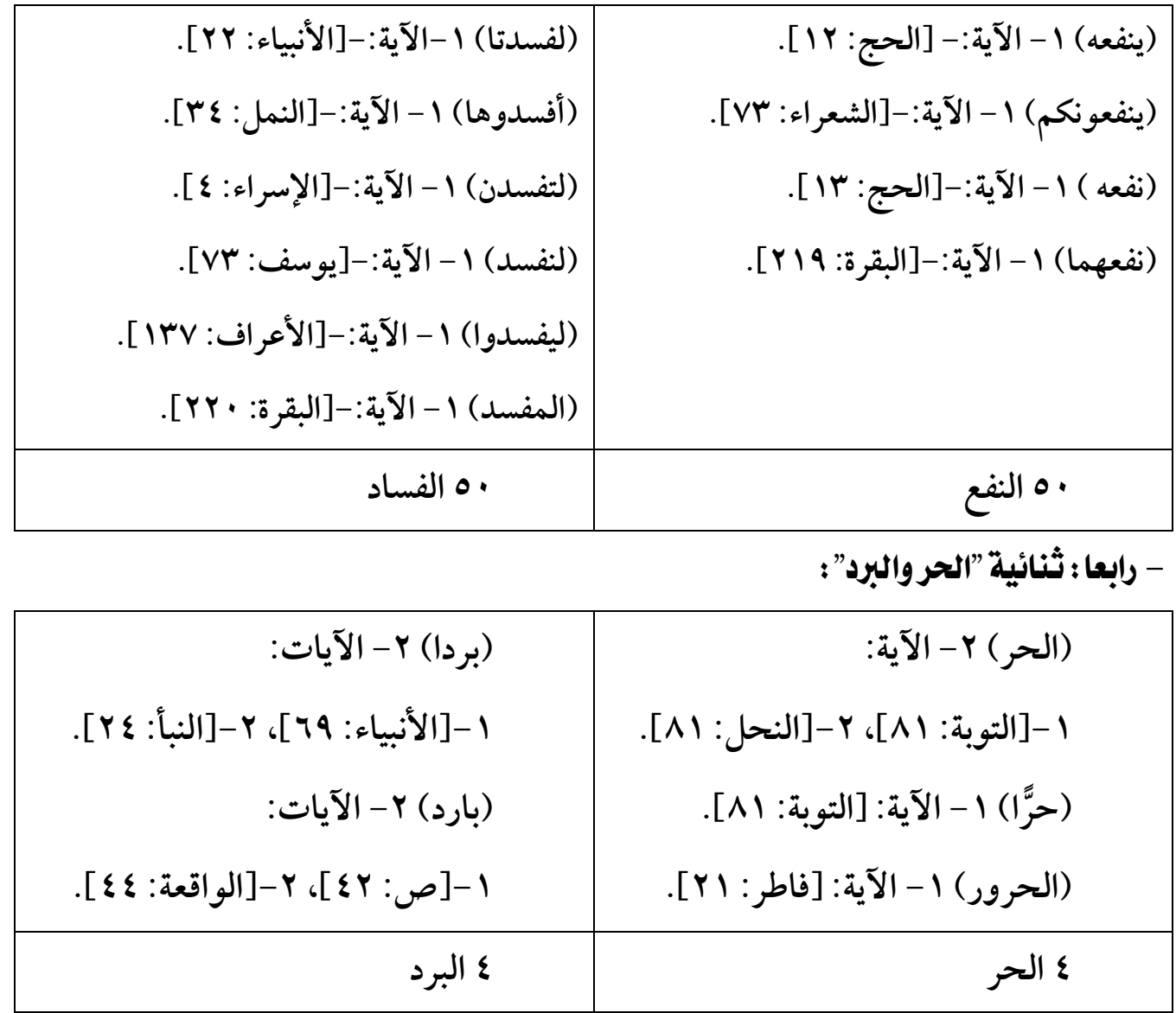

- خامسا : "ثنائية "الضيق والطمأنينة":

\begin{tabular}{|c|c|}
\hline (تطمئن) ا -الآية: [الرعد: Y^] & (ضاقت) | -الآية: [التوبة: \| ] ]. \\
\hline (وتطمئن) Y - الآية: & (وضاقت) r-الآية: \\
\hline 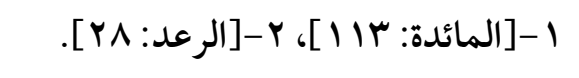 & 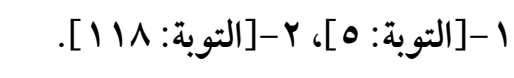 \\
\hline (ولتطمئن) ب -الآية: & 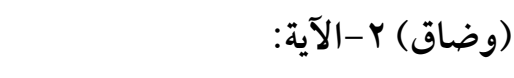 \\
\hline 1-[آل عمران: צr I]، צ-[الأنفال: • 1]. & 1-[هود: VVV]، Y-[العنكبوت: سr]. \\
\hline (مطمئنة) | -الآية: [النحل: Y | I ]. & (يضيق) ا -الآية: [الحجر : 9V]. \\
\hline (المطمئنة) ا -الآية: [الفجر: rV ]. & (ويضيق) ا -الآية: [الشعراء: سا]. \\
\hline (اطمأن) 1 -الآية: [الحج: 11]. & 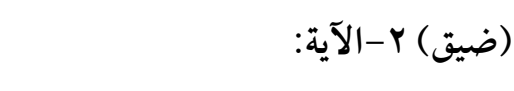 \\
\hline (اطمأنتم) ( - الآية: [النساء: بـ 1]]. & 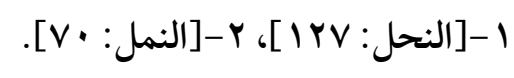 \\
\hline
\end{tabular}




\begin{tabular}{|c|c|}
\hline (واطمأنوا) ( - الآية: [يونس: V]. & 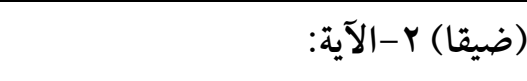 \\
\hline (ليطمئن) ( -الآية: [البقرة: • •r]. & 1-[الأنعام: هY 1]]، Y-[الفرقان: r|]. \\
\hline (مطمئن) ا-الآية: [النحل: ؟ - 1]. & (لتضيقوا) ا -الآية: [الطلاق: ج]. \\
\hline (مطمئنين) ا-الآية: [الإسر اء: 90]. & (وضائق) ا-الآية: [هود: Y I ]. \\
\hline rا الطمأنينة(1) & 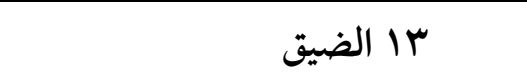 \\
\hline
\end{tabular}

وهكذا تفصح هذه المعدلات التكرارية المتناظرة عن خاصية أسلوبية ذات دلالة في سياق النص القر آني ينفرد بها عما دونه من النصوص المقدسة، حيث يعبِّ انظام المقابلة العددية عن معالم تلك الخاصية بوضوح شديد عندما تنطوي على انحراف واضح عن صدفوية اللغة الشائعة، "وليس كل انحر اف جديرا بأن يعد خاصية أسلوبية هامة، بل لابد لذلك من انتظام

ويفرض المنهج الأسلوبي الإحصائي في ضوء اطراد الظاهرة المتكررة لهذه الثنائيات المتضادة في النص الخاضع للدراسة التنقيب فيما وراء هذا الاطراد التضادي والكشف عن الدلالات الخبيئة لهذه الأرقام المتناظرة، أو - وفق تعبير برند شبلنر - "الانتقال من تفصيل دلالات الكم إلى تفصيل دلالات الكيف اعتمادا على ما تم حسمه من الدلالات الكمية الرياضية

( (1) اكتفى الباحث بهذه الثنائيات على سبيل التمثيل لا الحصر، حيث تفصح جهود الدارسين عن تحقق عدد

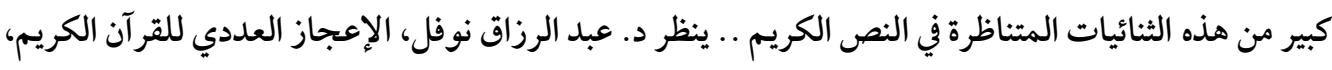
صـ roV-ro G.N. Leach بين (Y) د. سعد مصلوح، الأسلوب دراسة لغوية إحصائية، صـا ه، وفي هذا يفرق ج.ن ليتش ما يتضمنه النص من انحر اف متفرّد دال unique significant deviation وبين الشطط الذي لا متعة فيه ... unmotivated aberration 
التي تتسم بالمصداقية والحسم والدقة معا"(')، ومن ثم فإننا إذا انتقلنا من توثيق هذا التناظر الإحصائي إلى إجراء التحليل الموضوعي له، فلا ينبغي أن نتجاوز ما تفصح عنه هذه التقابلات المحكمة والمتكررة عبر السياق الإجمالي للنص القرآني من السمات الأسلوبية لهذا النص المؤسس في البدء على فكرة المثاني، ذلك لأن هذه المقابلات القرآنية المتناظرة إحصائيا المتحققة في الكتاب المسطور تتسق مع مشيئة الله تعالى في خلق الكون المنظور على صورة

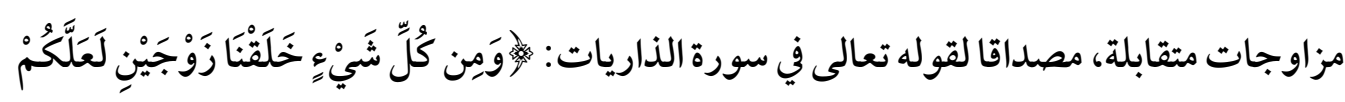

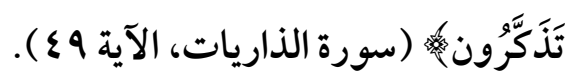

وقد أفصح عن هذا الوعي ببنية النص القرآني ومغزاه عددّ كبيرٌ من علماء التفسير واللغة والبلاغة، ومن ذلك أن الزركشي ينقل عن الشيخ أبي الفضل يوسف بن محمد النحوي القلعي أن كتاب الله كلَّه مؤسٌٌ على أسلوب المقابلة، إذ تتجلَّى هذه المقابلة في الكائنات والزمانيات والوسائط والروحانيات والأوائل والإلهيات، "حيث اتحدت من حيث تعددت، واتصلت من حيث انفصلت"(؟) لقد استخدم الشيخ أبو الفضل يوسف (ت VII هـ ) من حيث لا يدري آليات المنهج الأسلوبي الإحصائي في إثبات نسبة القرآن الكريم إلى الإله الواحد سبحانه وتعالى، وذلك عندما قرن الثنائيات الكونية (مثل الليل والنهار، الذكر والأنثى ... إلخ) في الكتاب المنظور (الكون) بالثنائيات اللغوية في الكتاب المسطور (القرآن الكريم)، حيث يثبت الأسلوبيون الإحصائيون نسبة الكتاب إلى مؤلفه عن طريق "القياس الكمي لسمات معينة في نصوص مقطوع نسبتها إلى

( (1) ينظر برند شبلنر، علم اللغة والدراسات الأدبية، صـ \& \& 1، وينظر تصور ميشيل ريفاتير حول هذالإجراء الذي بسطه د. صلاح فضل في كتابه بلاغة الخطاب وعلم النص، المجلس الوطني للثقافة والفنون والآداب،

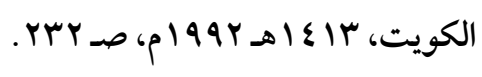

(r) ينظر الزركشي، البرهان، جـ، صـمه ؛ ،وينظر د. كمال عبد العزيز إبراهيم، أسلوب المقابلة في القرآن 


\section{المجلد الثامن والثلاثون إصدار يونيو.r. r.}

مؤلفيها ومقارنة نتائج القياس بما يتمخض عنه قياس السمات نفسها في النص مجهول المؤلف

$$
\text { أو المشكوك في نسبته إلى مؤلفه" ( ) }
$$

وفي هذا السياق تتبدَّى واحدة من أهم فوائد المنهج الأسلوبي الإحصائي، ألا وهي تحقيق نسبة النصوص إلى أصحابها the problem of autharship من خلال اكتشاف مدى الاتساق المتحقق في الظواهر اللغوية الخاضعة لعملية الإحصاء(؟)، وهو الاتساق الذي يتجلَّلى في النص القر آني على وجه ما كان ليتحقق في أي كتاب آخر على مدى التاريخ .. وتفصح المقابلات القرآنية عن قيمة التوحيد الذي هو أصل العقيدة القرآنية، ذلك لأن التناقض المتحقق في المطابقة بين المتقابلَين يؤكد افتقار كل نقيض لنقيضه، وهكذا تتجلَّى الآيات الدالة على وجود الله ووحدانيته - سبحانه - فيما جرت عليه حكمته من تأسيس قانون الخلق على الثنائيات التي تقتضي أن كل مخلوق يفتقر في تحقيق ذاته إلى شريكه، فلايُعْرَف النور إلا بوجود الظلام، ولا يُعرَف الليل إلا بوجود النهار، ولولا وجود الحياة ماعرف الموت، ولولا وجود الشياطين ما عرفت الملائكة، ولولا وجود البر ما عرف البحر، وهكذا فكل مخلوق يفتقر

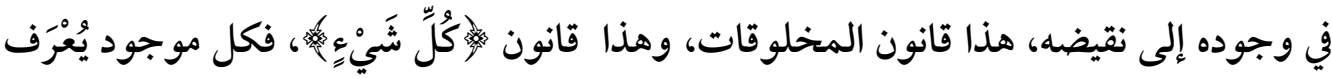
بشريكه، إلا الله الواحد الذي لا شريك له، لأنه الخالق الذي يُعْرَف بذاته، لا المخلوق الذي يُعْرَف بنظيره، ولو ظل الإنسان يبحث مدى الدهر عن ذلك المخلوق الذي يتحقق بذاته دون أن يفتقر إلى شريك له يُجْلِي خصائصه ويحققه كما يتحقق به لما استطاع إلى ذلك سبيلا، وهو ما يؤكد وحدانية الخالق لكل شيء الذي لا يفتقر لنقيض ليُعْرَفَ به لأنه واحد أحد، ولعل هذا ما

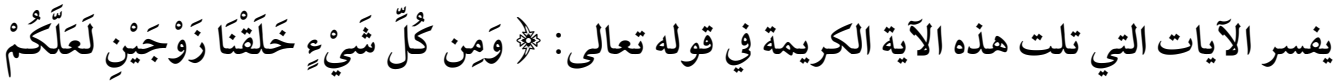

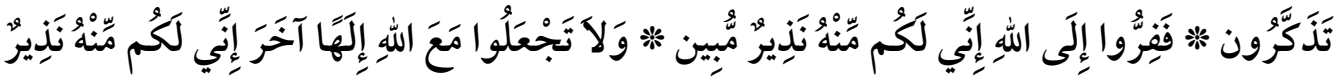

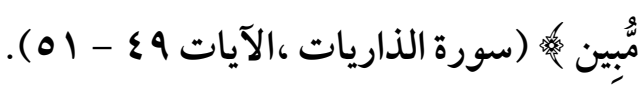

(1) (1) د. سعد مصلوح، الأسلوب دراسة لغوية إحصائية، صدץT.

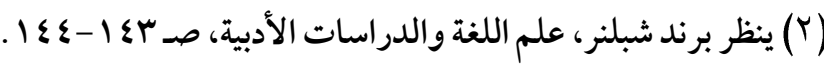


وهكذا فلما كانت ألوهية الخالق لا تثبت إلا بثبوت استغنائه عن المخلوق، فإن عبودية المخلوق لا تصدق إلا بثبوت افتقاره إلى الخالق، لأن صفة الافتقار تتعارض بحكم البديهة مع صفة الألوهية، وهو ما يستلزم - عقلا - اليقين بوحدانية الله، لأن الوحدانية تعني أن كل ما يجري على المخلوق من سنن مخلوقة بدورها لا تجري على خالق هذه السنن، وتتأكد الوحدانية المطلقة لله تعالى بالنظر إلى هذا الافتقار الذي يحيط بكل الخلائق، كبيرها قبل صغيرها، وقويها

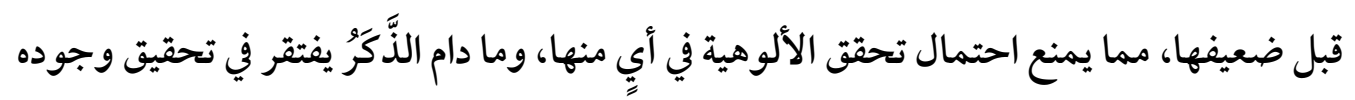
إلى ما يناظره (الأنثى)، والو الد يفتقر في تحقيق وجوده إلى ما يناظره (الولد)، فلا يستقيم عقلا أن

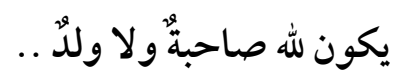
وتُصَدِّق آيةُ المثاني في سورة الزمر على هذا التأويل الذي يربط بين البنية التناظرية المتمثلة في مثاني القرآن من جانب وبين خشية الله والتعرف إليه وذكره من جانب آخر، يقول الله تعالى:

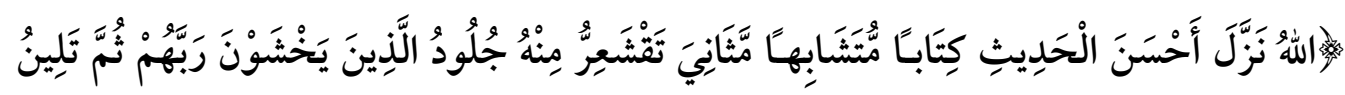

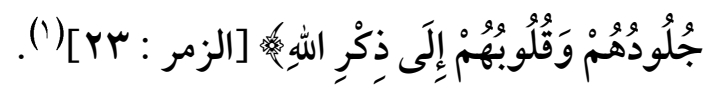
هكذا عبَّ القر آن عن هذه (الهندسة الكونية) التي تنبني على المزاوجة بين النقائض، لأن آي القرآن الذي هو كتاب الله المسطور - كما ذكر الشيخ أبو بكر يوسف القلعي - يعكس آي الكون الذي هو كتاب الله المنظور، وهكذا يؤكد هذا الضبط الممنهج للمتواليات العددية في

( (1) لقد جاءت كلمة "مثاني" في إثر كلمة "متشابها" دون أن يفصل بين الكلمتين فاصل من عطف أو خلافه

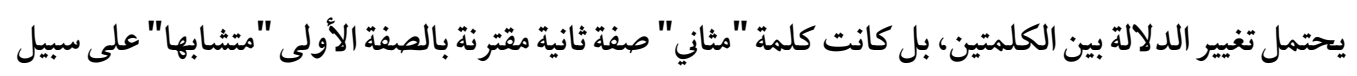

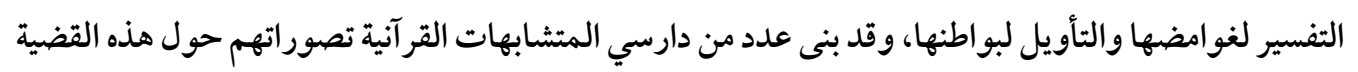
على هذا المفهوم القائم على الربط بين هذين الطرفين، ولعل آية ذلك كتاب ابن جماعة الذي يحمل عنوان

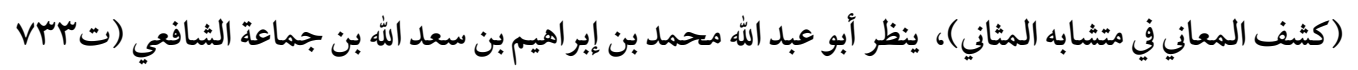
هـ )، كثف المعاني في متشابه المثاني، حققه وقدم له وعلق عليه د. محمد محمد داود، دار المنار للنشر والتوزيع،

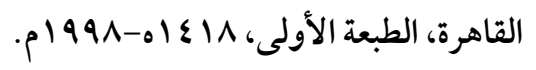


النسق التكراري لكلمات القرآن الكريم على حقيقة واضحة مؤداها أن كلام الله الذي نزل على محمد - صلى الله عليه وسلم - مُنَجَّمًَا عبر ثلاثة وعشرين عاما هو قول واحد لإله واحد، وما هو بقول بشر، ولو كان كذلك لما جاء مسبو كا على هذه الحال البليغة في الضبط والحصر، وفي هذا السياق تتبدي أهمية أمية النبي محمد - صلى الله عليه وسلم - ، لأنه لو كان قارئا كاتبا لظن المر جفون أنه هو من علَّد هذه المقابلات وحصر ها، وإن افترضنا - جدلا - هذا الاحتمال فلماذا لم يشر إليه وقد بذل فيه هذا الجهد المضني ..

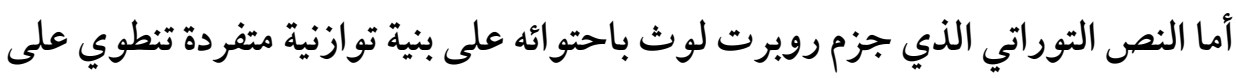
أسرار مقدسة لا تتحقق فيما سواه من النصوص البشرية (')، فلا يفصح التحليل الإحصائي لهذا النص عن أية دلالة تناظرية في تعداد مفرداته يمكن أن تحمل اتساقا Consistency أو نمطا مائزا norm Differntial على الوجه الذي سبقت تجليته في النص القرآني، وهو ما يتجلَّى بوضوح في المعادلات النهائية التي انتهت إليها هذه الجداول:

ثنائية الشياطين والملائكة : - م

\begin{tabular}{|c|c|}
\hline IV : 1 ا -سفر أخبار الأيام الأول[الإ & مة) ب: ا-سـفر \\
\hline 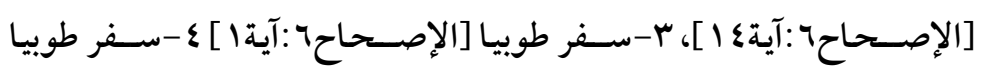 & ر [الـمـزمـور \\
\hline "آية9 19]، ه-سـفر طوبيا [الإصسحا & ففر \\
\hline 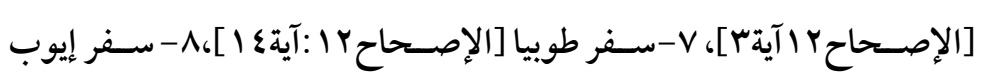 & 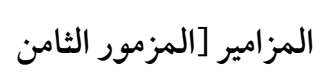 \\
\hline 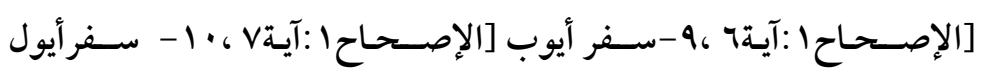 & 每 \\
\hline 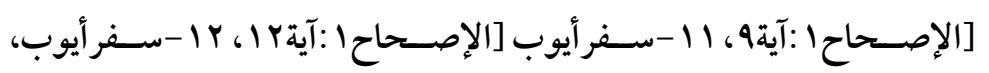 & كمة [الإصحاح \\
\hline
\end{tabular}

( (1) حيث نص على ذلك في حديثه عن سمات التوازي في الاستعارات النبوية مشيرا إلى أنه تتعذر المقارنة بين هذا الشعر المقدس وما دونه من دنس، وهذا نص حديثه: This species of metaphor excellently adapted to the sacred poetry, and " particularly to the prophetic; not easy to form any comparison between the sacred and profane poetry in this respect." (Robert Lowth, 1829, ibid, .P73) 


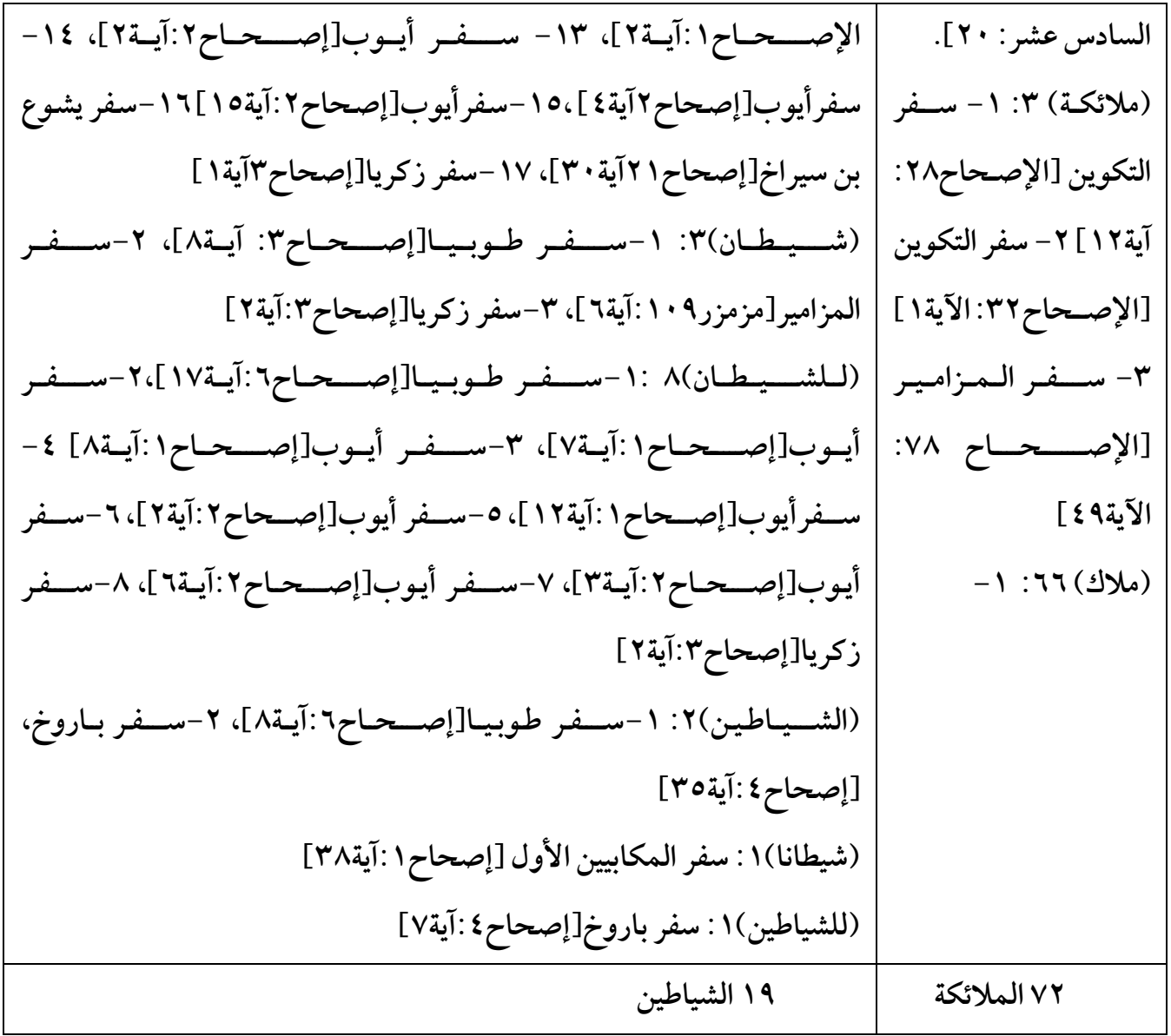

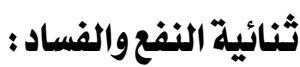

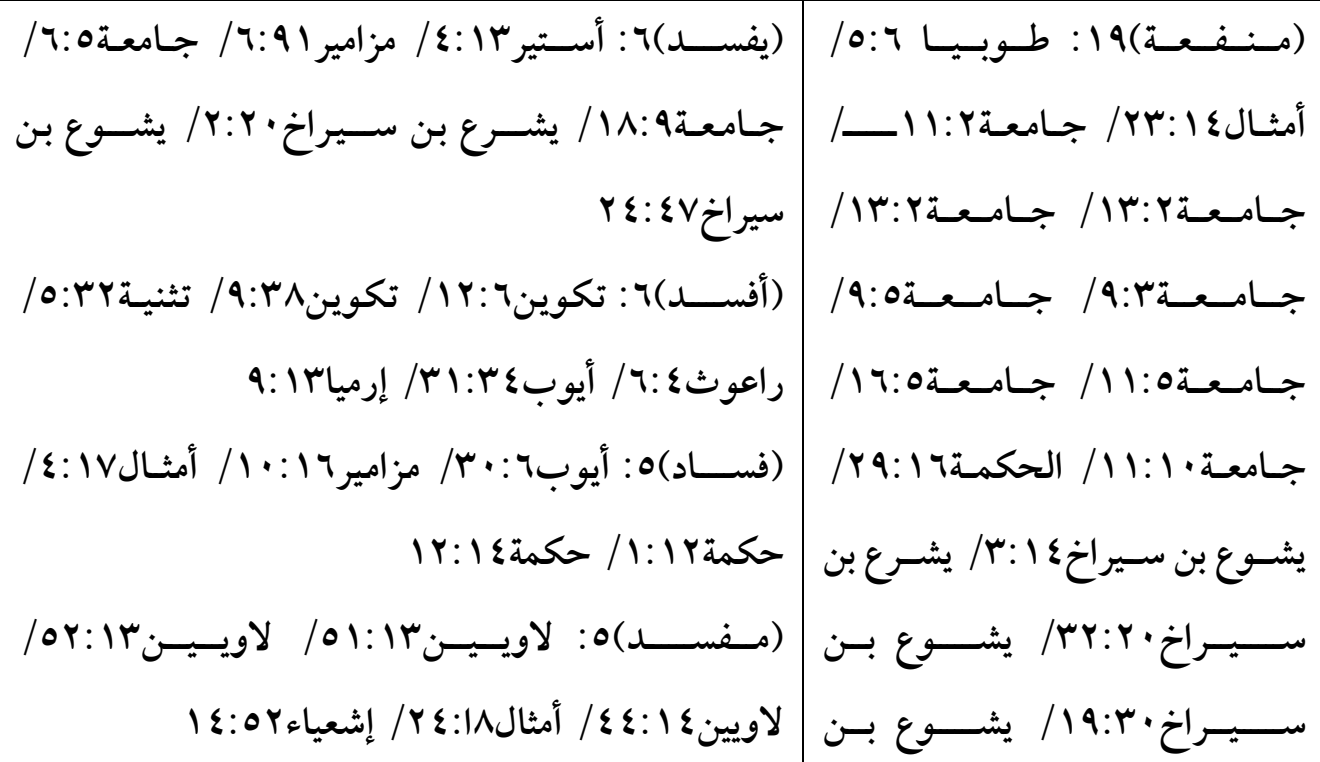


المجلد الثامن والثلاثون إصدار يونيو. r.r.

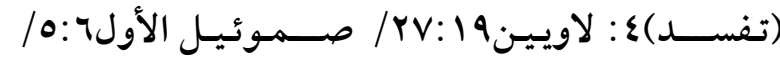

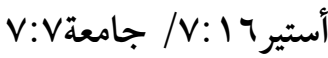

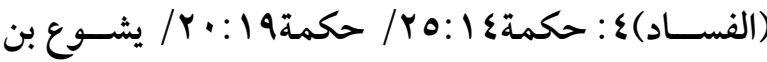

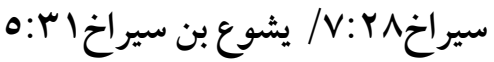

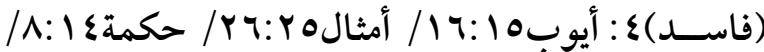

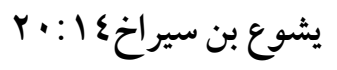

$/ r: 1 \varepsilon$

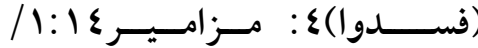

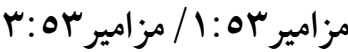

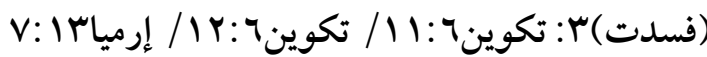

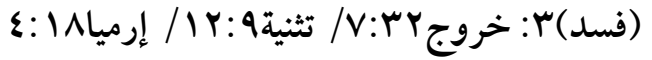

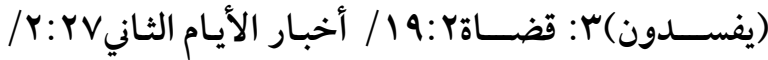

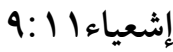

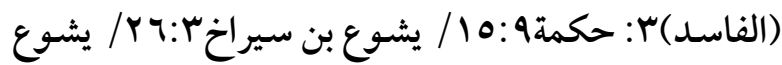

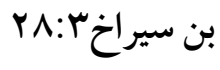

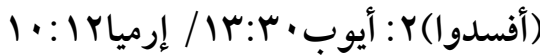

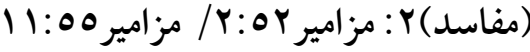

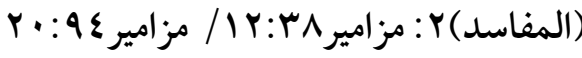

(تفسدون) ץ: تثنية اس:9 / / الملوك الثانيץ:19

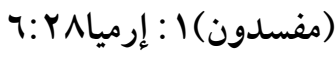

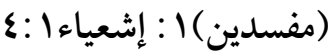

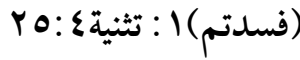

(تفسدوا) ا : تثنية : (17)

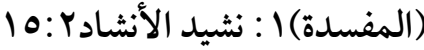

(فاسدة) ا : أستيرس| :0

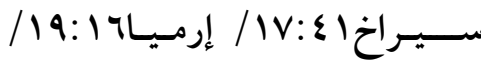

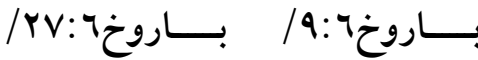
باروخج

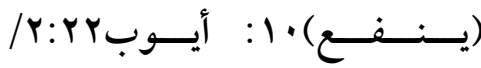

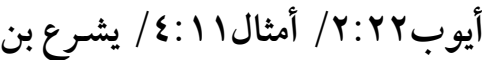

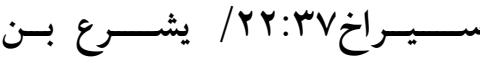
ســـاخ

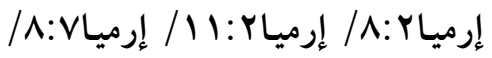
10:10: باروخ

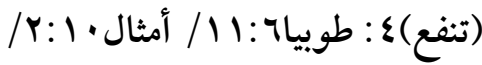

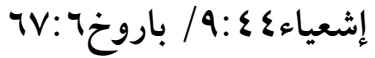
(تنفعك) ب: يشرع بن سيراخه : •

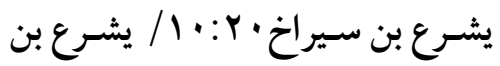
سيراخ·r:Y

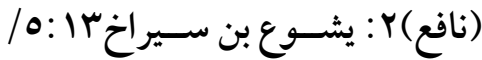

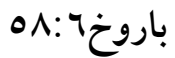

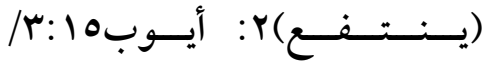

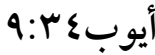
(ينفعهم) |:إشعياء ·r:0

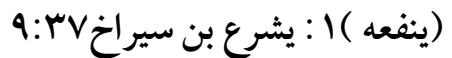
(نفع) ( : سفر إستير7 17 V: (منفعتة) ا : يشوع بن سيراخ/ (للمنفعة) ا : إشعياء ·r:0 (منافع) ( : الحكمة ب:7 


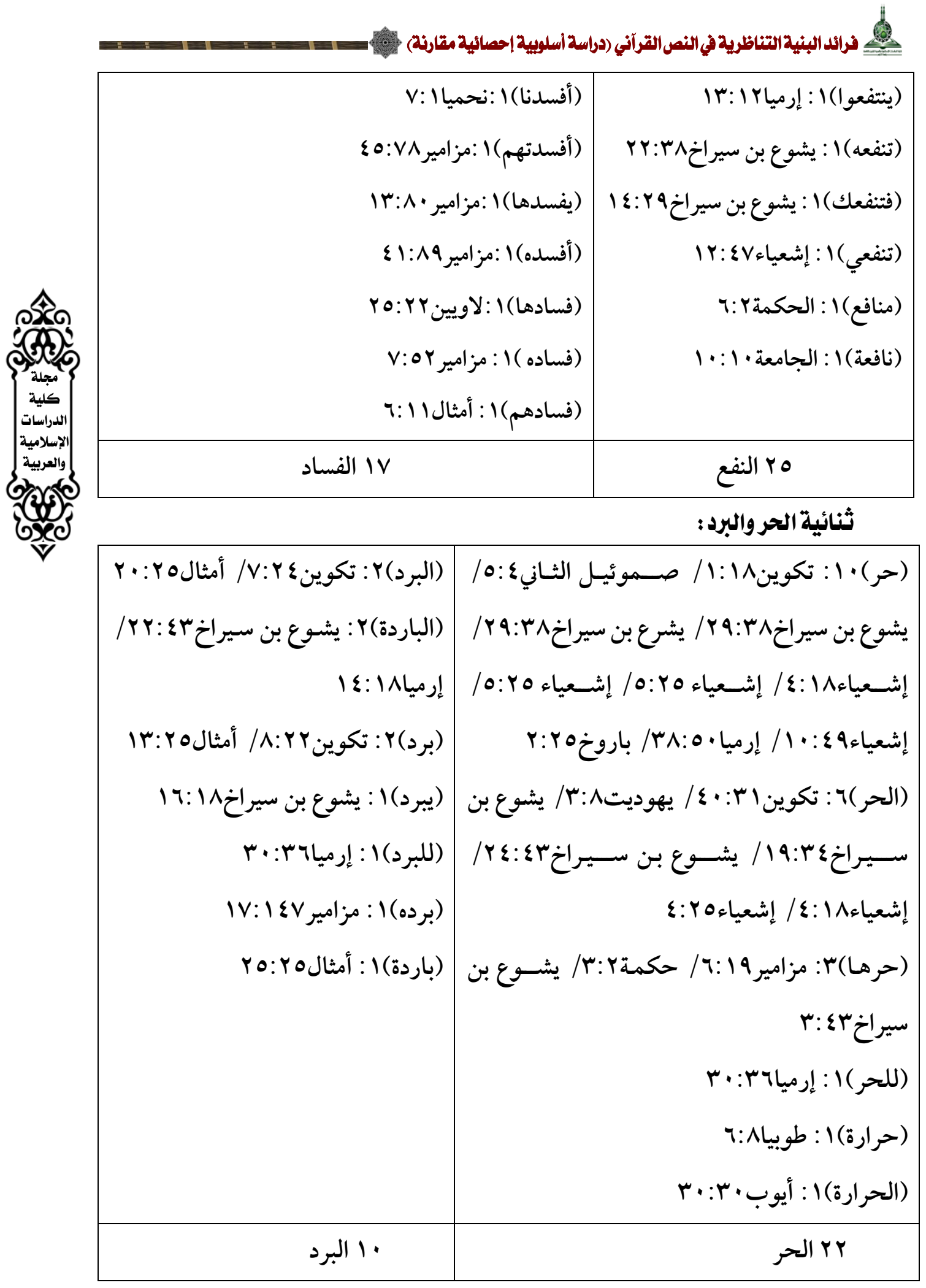




\begin{tabular}{|c|c|}
\hline (الطـمـأنـيــــة)مـــــان & 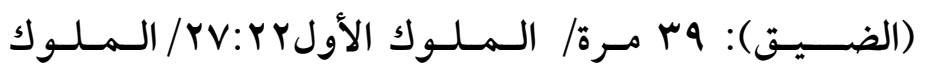 \\
\hline 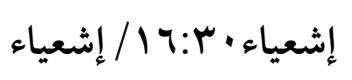 & لأيــام الـثـــي/ :جـ/ أخـبــار الأيـام \\
\hline$\wedge: 乏 \vee$ & 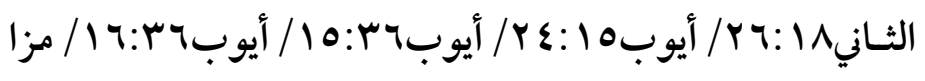 \\
\hline 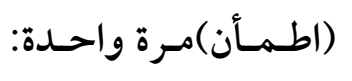 & 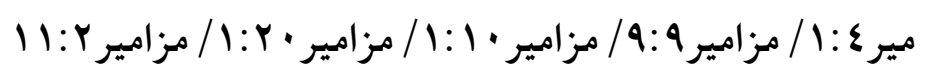 \\
\hline 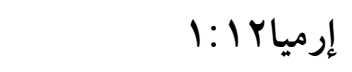 & 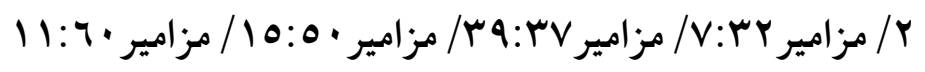 \\
\hline 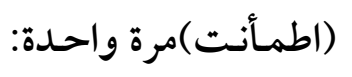 & 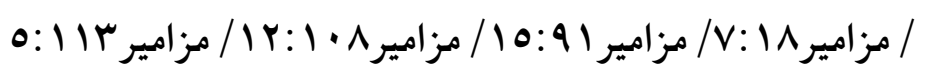 \\
\hline 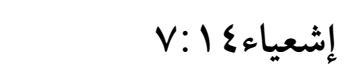 & 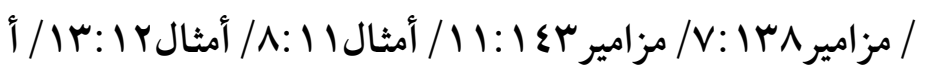 \\
\hline 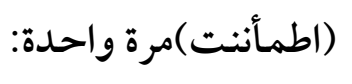 & 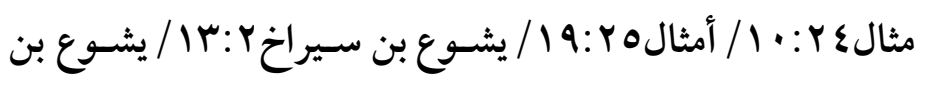 \\
\hline 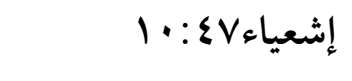 & 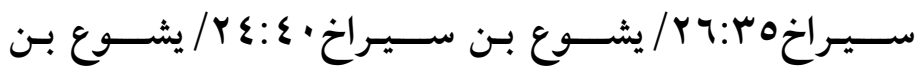 \\
\hline 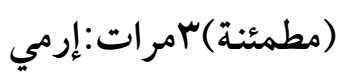 & 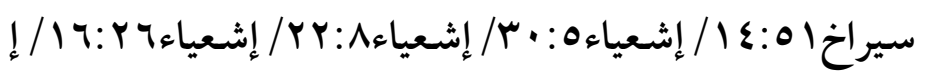 \\
\hline 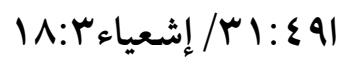 & 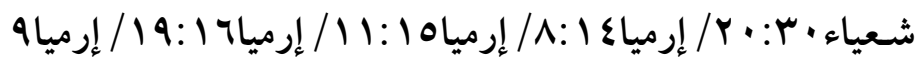 \\
\hline ر الأيــام & 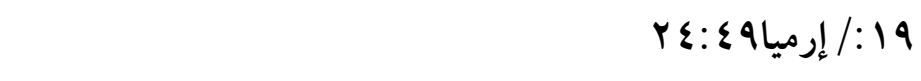 \\
\hline 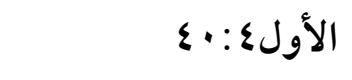 & 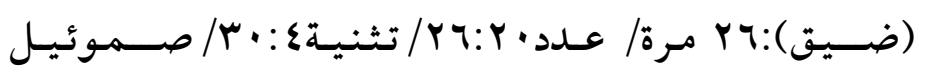 \\
\hline 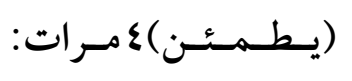 & 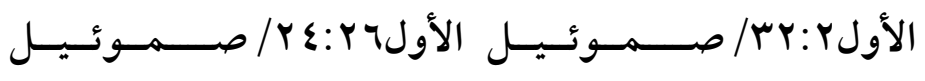 \\
\hline أيوبr:1 ا أيوبrr & الثـاني7: ا / الملوك الثـايجا : ـ / الملوك \\
\hline 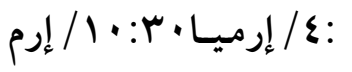 & ק \\
\hline يا7 & 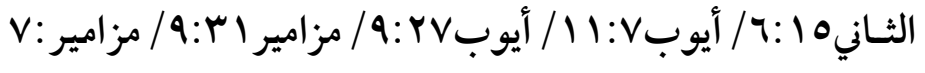 \\
\hline 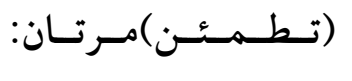 & 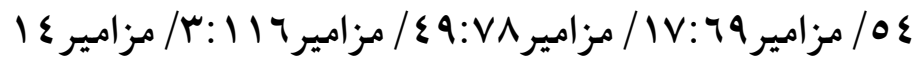 \\
\hline 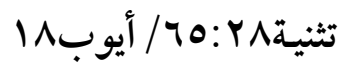 & 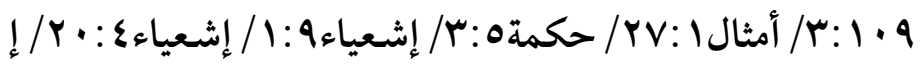 \\
\hline 11: & 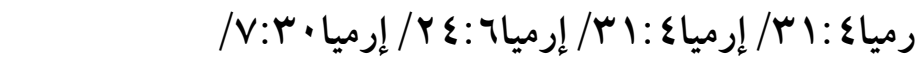 \\
\hline & \\
\hline
\end{tabular}




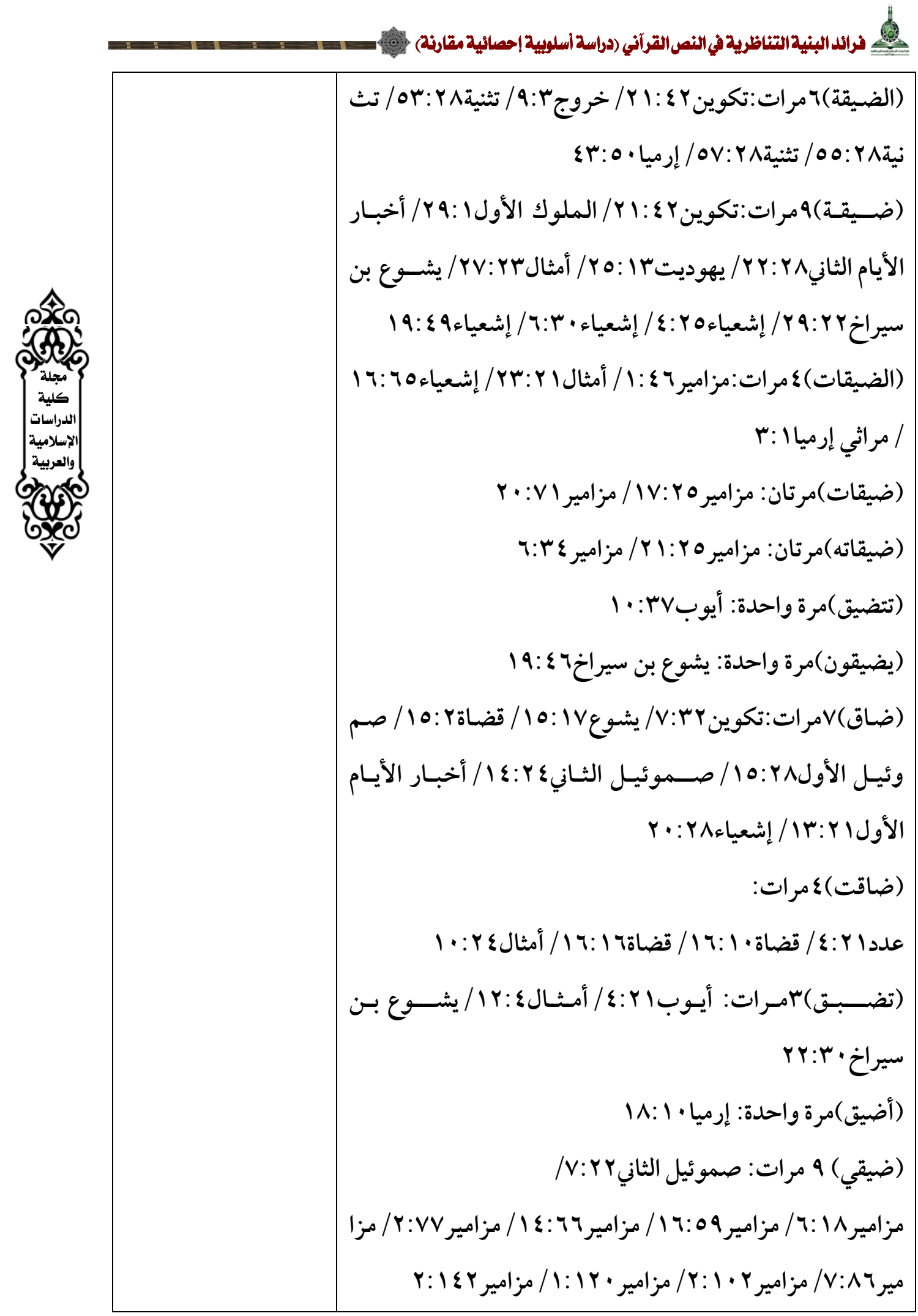




\begin{tabular}{|c|c|}
\hline & 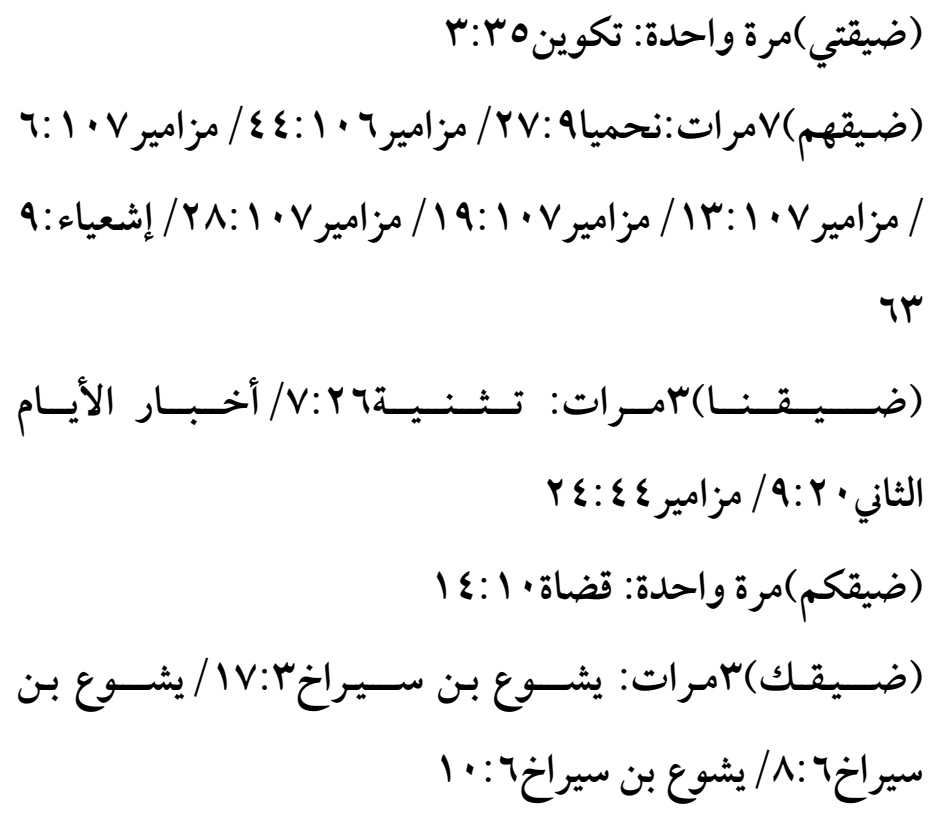 \\
\hline ع ا الطمأنينة & 9 ا الضيق \\
\hline
\end{tabular}

ولا تقف البنية التناظرية في مجمل النص القرآني عند حد هذه التناظريات الأسلوبية الإحصائية المتعلقة بتكرار المفردات، بل تتعدى ذلك إلى التناظريات الموضوعية التي تنتظم مجمل النص القرآني أيضا، وفي حين لم يشر “روبرت لوث" إلى وجوه التوازي المؤسسة على الاختلافات الأسلوبية بين أسفار التوراة المختلفة زمانيا ومكانيا وموضوعيا كتلك التي ينبغي أن تتحقق بين سفر التكوين وسفر الخروج - على سبيل المثال - فإن الدراسات البلاغية للقرآن الكريم قد اشتغلت بأثر اختلاف السياق الزماني والمكاني والموضوعي على اختلاف الأساليب القرآنية، كما هو الشأن في البنية التناظرية المتحققة بين الآيات المكية والآيات المدنية، حيث يتسق اختلاف السياق الزماني والمكاني مع اختلاف أسلوبي يتجلَّلى في الموضوعات والتراكيب والأصوات، وتطرد التوازنات القر آنية بصورة متكررة في القرآن المكي بوجه أكثر وضوحا من القرآن المدني، كما أن العبارات المتوازنة تبدو في القرآن المكي أقصر وأوجز من نظائرها في القرآن المدني، ويؤكد عدد كبير من الدارسين على هذه الملاحظات، ومن ذلك ما أشار إليه الدكتور عفت الشرقاوي وسلكه ضمن "أسرار الإعجاز القرآني في الجملة المكية من أنها تعتمد 


\section{فرائل البنية التناظريح في النص القرآني (دراسح اسلوبية إحصائية مقارنة)}

على مراعاة التوزان، وهذا التوازن يتخذ أوصافا كثيرة، فطورا تقوم الجمل فيه على الِِصَر والتلاحق، وطورا يكتفى فيه بمعنى الازدواج الفكري، ولكن يحتفظ فيه بالتوازن الصوتي والازدواج الفكري الذي يقوم على المقابلة بين الأفكار، وقد يضم إلى ذلك المقابلة بين الأصوات، وإذا كان كل جانب من جوانب اللغة يجب أن يتلون بلون مجاله، فقد اقتضى الإعجاز العظيم أن يكون الإعجاز في الجملة المكية قرين بساطة الرسالة في طورها الأول، وقرين الاعتماد على حاجة النفس للنص مما كان مطلوبا في هذا الطور من تاريخ الدعوة، كذلك يحتاج إلى الاختصار في معرض الإشارة السريعة إلى مجملات فصلت مع الزمن في الجملة المدنية ذات المتعلقات والإضافات"( (1)

وفي هذا السياق يقول د. كمال عبد العزيز إبراهيم: "وأسلوب المقابلة في القرآن المكي

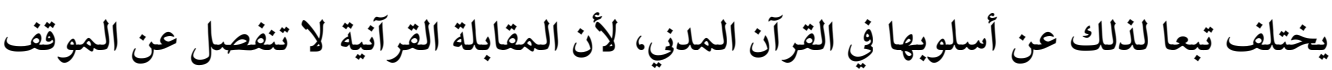
الذي قيلت فيه، ولاعن السياق الأسلوبي المعبر عن هذا الموقف، إنها لبنة في البناء التعبيري

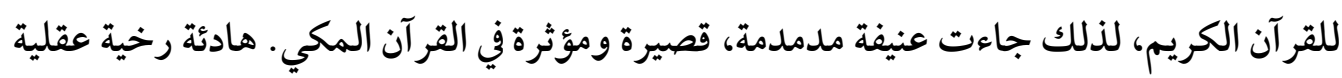
ومنطقية في القرآن المدني.

وقد كثر ورود المقابلة في القرآن المكي في المواقف التي اقتضتها نشأة العقيدة، واستلزمها بناؤها على أسس التوحيد الخالص وما يستتبعه من الإيمان بالله وملائكته وكتبه ورسله واليوم

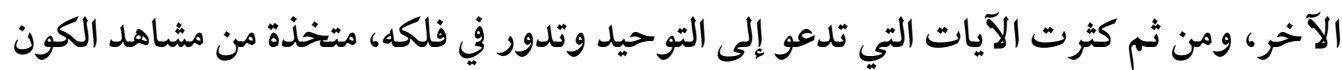

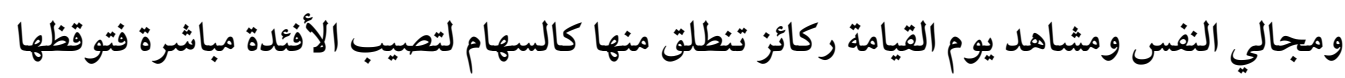
من سباتها وغفلتها. بينما وردت المقابلة في القرآن المدني في مواقف التشريع وبيان المعاملات ومواقف الجهاد، وتوجهت بالخطاب إلى النبي وإلى المؤمنين وإلى المنافقين واليهود، تعلم وتؤدب وبي

( (1) د. عفت الشرقاوي، الفكر الديني في مواجهة العصر، دار الحقوق للطبع والنشر والتوزيع، القاهرة، ـ19 (م)، 
وتربي، وتفضح مكائد المنافقين وغدر اليهود"( (). وتتعدد صور التناظر التقابلي في مجمل كتاب الله الكريم لتؤكد على تفرد هذا النص العظيم في هذا الإطار عن النصوص الأخرى التي وقف التناظر التقابلي فيها عند حد الكلمتين أو أو

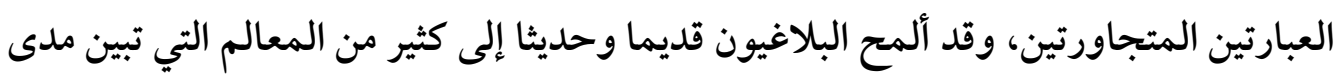
ذيوع هذه التناظرية التقابلية في أضعاف النص بين السورة وما يجاورها، كما هي الحال في التقابل

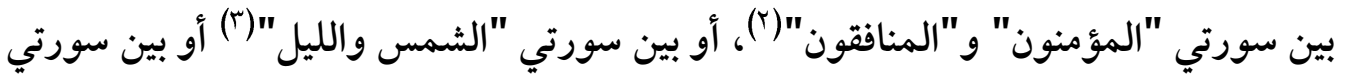

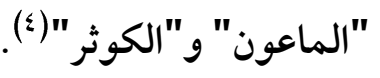

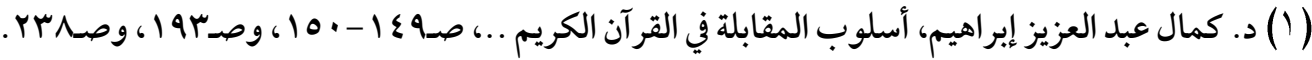

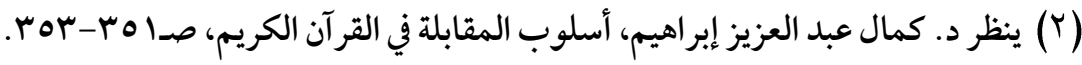

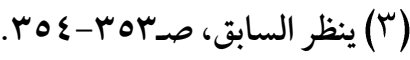

(ع) ينظر البيضاوي (القاضي ناصر الدين أبو سعيد عبد الله بن عمر بن محمد الشيرازي (ت V9 لهـ )، أنوار

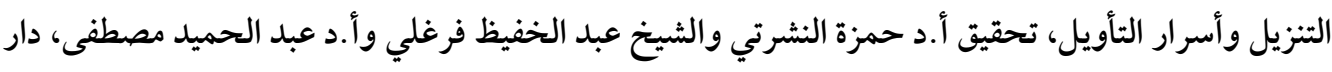

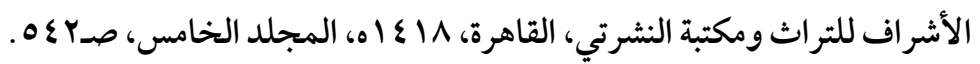




\section{التناظرية الترادفية}

- التوازي الترادفي في النص التوراتي من خلال دراسة" ”روبرت لوث”؛

تجلَّت البنيات الترادفية في اللون الذي أطلق عليه لوث اسم الازدواج أو التوازي الترادفي

Synonymous pairs والمشاعر والمعاني، وهو النوع الأكثر شيوعا من أنواع التوازي"(()، وأشار “روبرت لوث" إلى انقسام التوازي التر ادفي إلى عددٍ من الأقسام، تفصيلها ما يلي:

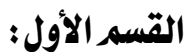

تُكَرِّرُ الكلمة أو العبارةُ الثانيةُ معنى الكلمة أو العبارة الأولى دون لفظها، وهو ما يتجلَّى في

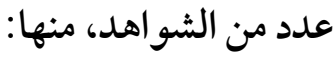

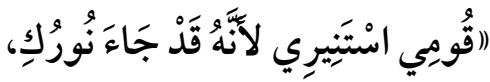

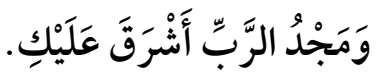

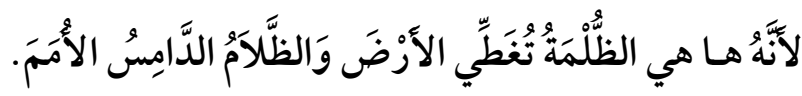

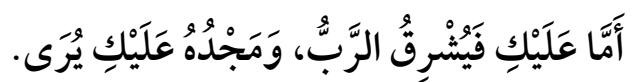
فَتَسِيرُ الأمَمُ فِي نُورِكِ، وَالْمُلُوكُكُ فِي ضِيَاءِ إِشْرَاقِكِكِ"(سفر إشعياء، الإصحاح السادس،

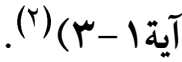

حيث تترادف كلمات مثل استنيري، ونورك، وأشرق، وفي نورك، وفي ضياء إشر اقك، كما

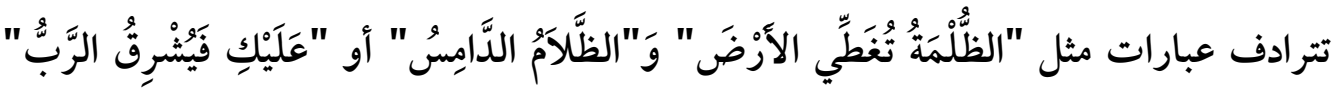

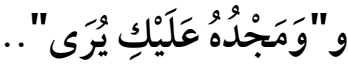

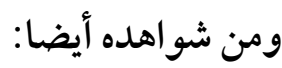

(1)Robert Lowth ،Lecture on the sacred poetry of Hebrews ‘p157. (2)Ibid, p157 


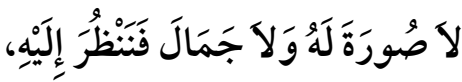

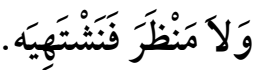

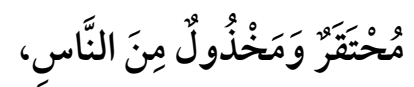

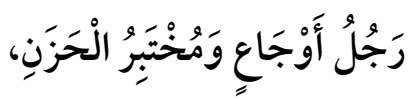

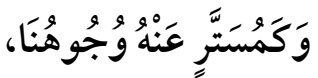

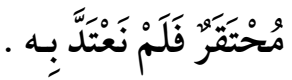

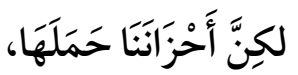

وَأَوْجَاعَنَا تَحَمََّلَهَا.

وَنَخْنُ حَسِبْنَاهُ مُصَابًا مَضْرُوبًَا مِنَ اللهِ وَمَذْلُولَا.

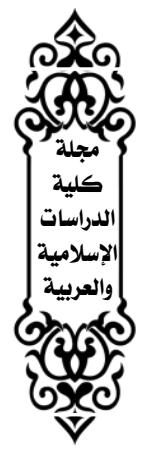

وَهُوَ مَجْرُوحُح لأَجْلِ مَعَاصِينَا،

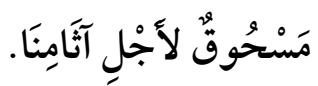

تَأْدِيبُ سَلاََمِنَا عَلَيْهِ،

وَبِحُبرِِِ شُفِينَا" (إشعياء، الإصحاحسه ، الآيات أ-ه ) (').

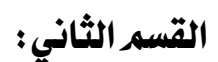

وفيه تُكرِّرُ العبارةُ الثانيةٌ معنى العبارة الأولى ولفظها، وهو ما يتسق مع فن التكرار في البلاغة العربية، ومن شواهده:

"( كَثِيرًا مَا ضَايَقُوني مُنْذُ شَبَبَبي").

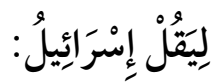

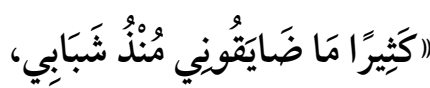

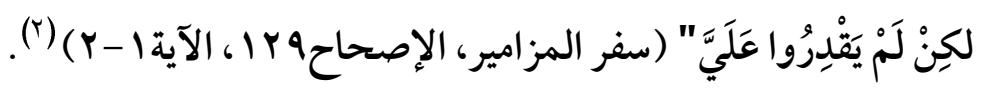

(1)Ibid, p158.

(2) Ibid, p158. 


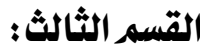

تُكَرِّرُ العبارة الثانية جزءا من العبارة الأولى لفظا ومعنى أو معنى فقط،

$$
\text { فمما تكرر معنى فقط: }
$$

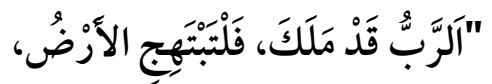

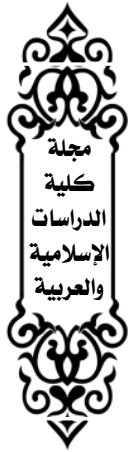

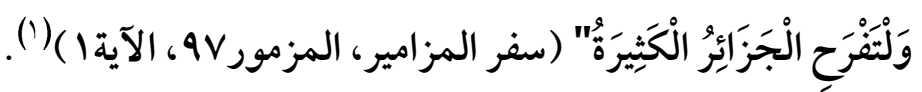

ومما تكرر لفظا ومعنى:

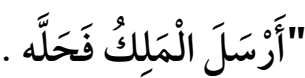

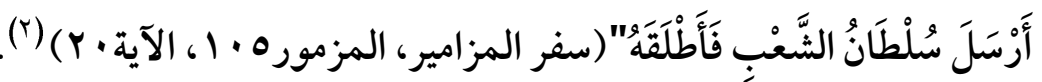

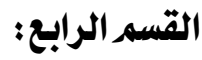

وفيه تترادف ثلاث عبارات بطريقة خاصة، حيث يترادف السطر الثاني مع السطر الأول،

ثم يشير السطر الثالث إلى كلا السطرين السابقين، وهو الوجه الذي أطلق عليه "لوث" تسمية

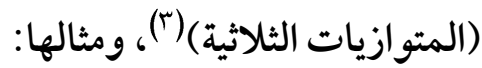

$$
\begin{aligned}
& \text { "رَفَعَتِِ الأنْهَارُ يَا رَبُّ، } \\
& \text { رَفَعَتِ الأَنْهَارُ صَوْتَهَا. }
\end{aligned}
$$

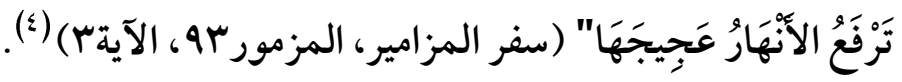

حيث ترادف العبارةٌ الثانيةٌ العبارةً الأولى، ويشير السطر الأخير إلى كلا السطرين السابقين، لأن في عبارة "ترفع الأنهار" إشارة إلى السطر الأول والثاني، وفي كلمة "عجيجها" إشارة ترادفية إلى كلمة "صوتها" في السطر الثاني.
(1) Ibid, p159.
(2) Ibid, p159
(3) Ibid, p159
(4) Ibid, p159 
وفيه يتألف المقطع من أربعة أسطر يشير السطران الأخيران فيها إلى السطرين الأولين (بالتناوب)، حيث يترادف السطر الثالث مع السطر الأول ويتر ادف السطر الرابع مع السطر الثاني، ومثاله من سفر المزامير:

$$
\begin{aligned}
& \text { "مِنَ السَّمَاوَاتِ نَظرَ الرَّبُّ. } \\
& \text { رَأَى جَمِيعَ بَنْي الْبَََرِ . } \\
& \text { مِنْ مَكَانِ سُكْنَاهُهُ تَطَلَّعَ إِلَّى }
\end{aligned}
$$

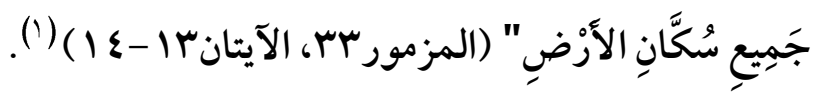

$$
\text { ومن سفر إشعياء: }
$$

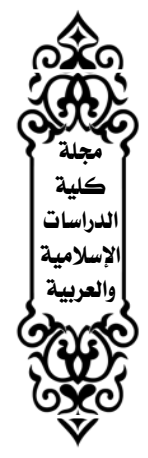

"لأَنَّبَعْلَكِ هو صَانِعُكِكَ،

$$
\text { رَبُُّ الْجُنوُوِِ اسْمُهُ، }
$$

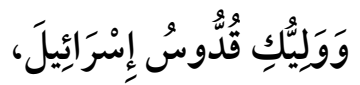

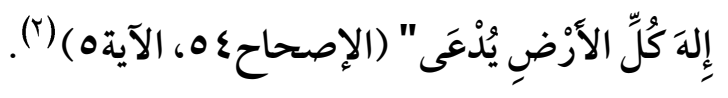

$$
\begin{aligned}
& \text { "وَامْتَلَأَتْ أَرْضُهُهم فِضَّةَ وَذَهَبًا }
\end{aligned}
$$

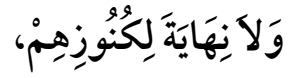

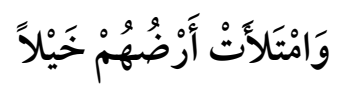

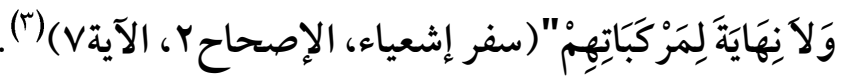

ويُحقق هذا اللون من التشكيلات الرباعية صورة تتسم بقدر ملحوظ من التركيب
(1) Ibid, p160.
(2) Ibid, p160.
(3)Ibid, p 161. 
والتداخل، أبرزها “روبرث لوث” من خلال هذا الشاهد من سفر المزامير :

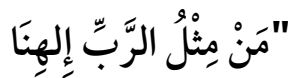

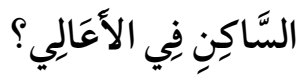

النَّاظِرِ الأَسَافِلَ

في السَّمَاوَاتِ وَفِي الأرْضِ" (المزمورسا اه، الآيتانه-7)(1). ويقول “روبرت لوث" في

تفصيل موضع الشاهد: "هنا نجد العبارتين الأخيرتين تشيران بقوة إلى العبارتين الأوليين، كما لو كان الترتيب على الوجه التالي: (من مثلك ليسكن في السماوات، ومن يرضى لنفسه مثلك أن

يتفقد الأشياء في الأرض؟)"(r).

ويّالاحظ أن هذا الشاهد - على وجه التحديد - أقرب إلى التوازي التقابلي لما فيه من

تقابل بين الأعالي والأسافل من جانب والسموات والأرض من جانب آخر، ورغم ذلك وضعه

$$
\text { روبرت لوث في شواهد التوازي الترادفي لسبب غير معلوم .. }
$$

- التوازي الترادفي بيز العهل القديمـوالنص القرآني:

أحاطت الدراسات القر آنية بهذه الأنماط التي انتهت إليها تصورات روبرت لوث لأقسام

التوازي الترادفي، ولكنها تناولتها من خلال معالجات وصفية تتسم بالتحليل النصي أكثر مما تعتمد على التقعيد النظري كما هي الحال في المعالجات المعيارية عند روبرت لوث، وفيما يلي سرد لهذه الأقسام وما يناظرها في القرآ الكريم:

- القسه الأول : تكرار الكلمة/العبارة الثانية معنى الكلمة/العبارة الأولى دوز لفظها : أشار عدد كبير من دارسي النص القرآني إلى هذا اللون من تكرار معاني الكلمات والعبارات دون ألفاظها، وقد صرَّح يحي بن حمزة العلوي بانقسام التكرار القر آني إلى قسمين: أحدهما من جهة اللفظ وثانيهما من جهة المعنى وبسط حديثا مطولا في سرد الشو اهد الدالة على

(1) Ibid, p161

(2) Ibid, p161. 


\section{المجلد الثامن والثلاثثرن إصداريونيو·r.r. r.}

كل قسيم وتجلية القيم البلاغية الكامنة وراء كل شاهد(')، وقد بلغت دراسات البلاغيين لهذا القسم الثاني غايات سامية من الإحكام والضبط، فقي دراساتهم الوصفية لملامح التكرار والتشابه في النص الكريم كثف الدارسون النقاب عن كثير من القيم البلاغية الكامنة في الترادف الذي يقع في المعنى دون اللفظ بين الكلمتين المتجاورتين في القر آن الكريم فيما يمكن أن نطلق عليه تسمية [العدول عن التكرار اللفظي إلى التكرار المعنوي] كما هي الحال في قوله تعالى: الرَّحْمَنُ

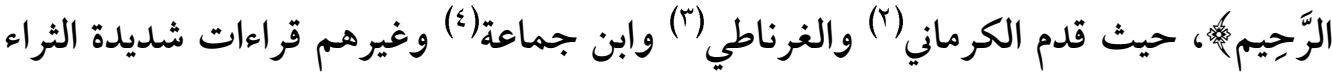
لهذه التجليات، كما أبرز هؤلاء وغيرهم الأسرار البلاغية للتشابه بين الجملتين المتجاورتين،

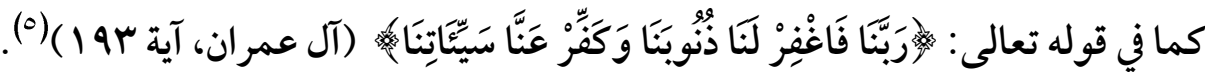
- - القسه الثاني : وفيه تُكَرِرُ الكلمة أو العبارةُ الثانيةُ معنى الكلمة أو العبارة الاؤلى ولفظها : بسط دارسو القرآن الكريم عددا هائلا من الصفحات في سبيل تفصيل هذا القسيم الثاني في

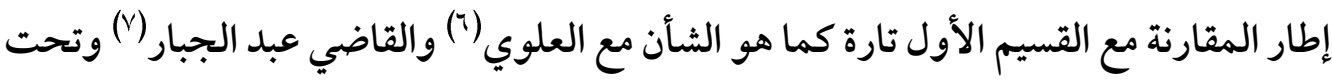
باب التكر ار في القر آن الكريم تارة أخرى .. وقد تناول الدارسون تكرار الكلمة كما في قوله تعالى :

( (1) ينظر الطراز المتضمن لأسرار البلاغة وعلوم حقائق الإعجاز، تقديم د. إبر اهيم الخولي، الهيئة العامة لقصور

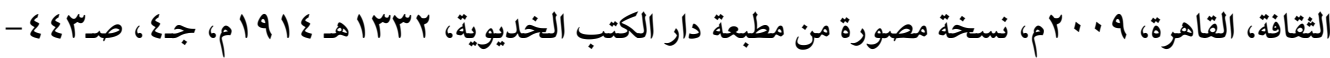

$$
\begin{aligned}
& \text { (Y) ينظر أسرار التكرار في القرآن، صده7. }
\end{aligned}
$$

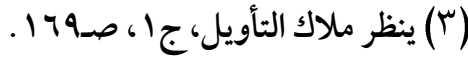

$$
\begin{aligned}
& \text { ( ) ينظر كشف المعاني، صـاه و وهo. } \\
& \text { (0) ينظر روح المعاني، المجلد الثاني، صـ11. }
\end{aligned}
$$

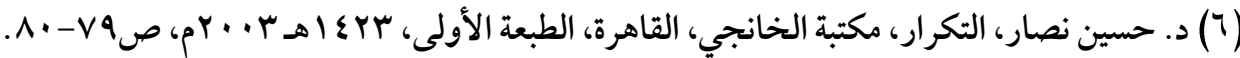
(V) ينظر د. عبد الفتاح لاشين، بلاغة القرآن في آثار القاضي عبد الجبار وأثره في الدراسات البلاغية، دار القرآن،

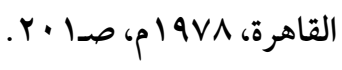




\section{فرائل البنية التناظرية في النص القرآني (دراسة أسلوبية إحصائية مقارنة)}

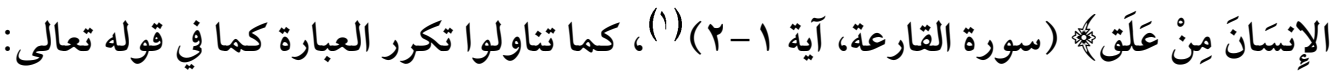

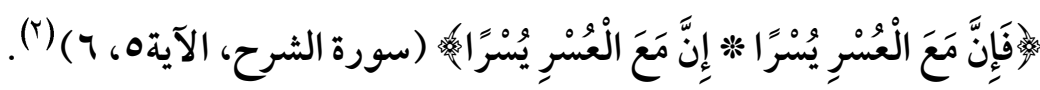
- القسه الثالث : وفيه تكرر العبارة الثانية جزءا من العبارة الأولى لفظا ومعنى :

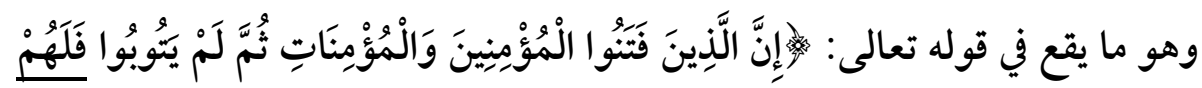

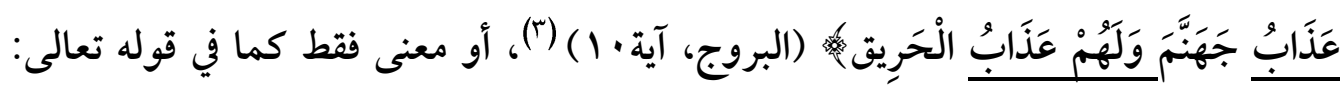

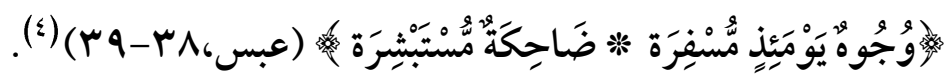
- القسم الرابع:

وهو ما يسميه لوث (المتوازيات الثلاثة)، وفيه تترادف ثلاث عبارات بطريقة خاصة، حيث يترادف السطر الثاني مع السطر الأول، ثم يشير السطر الثالث إلى كلا السطرين السابقين،

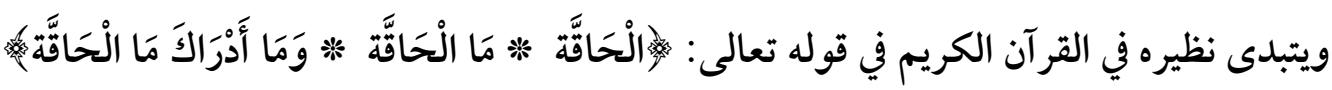

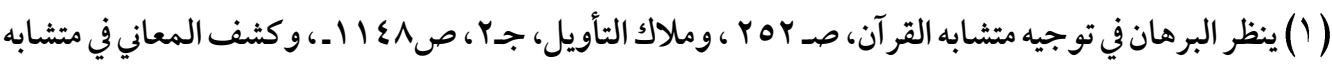

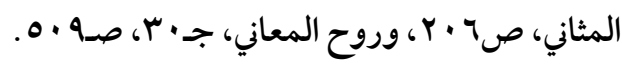

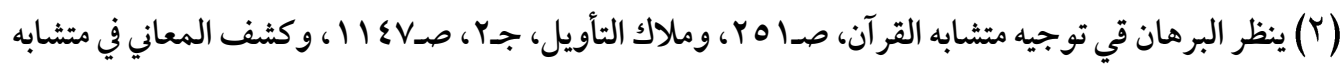
المثاني، صده -r. (广) ينظر محمد الطاهر بن عاشور، التحرير والتنوير، حيث فسر عطف كلمتي العذاب بين العبارتين فقال:

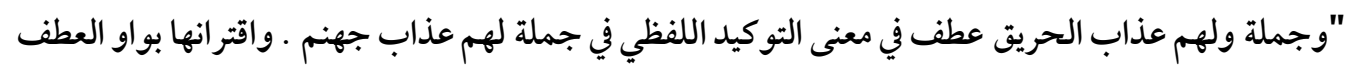

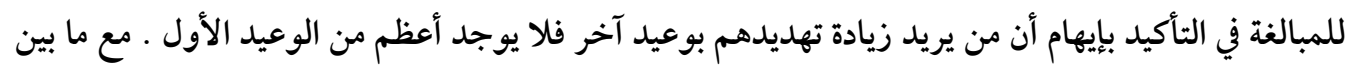
عذاب جهنم وعذاب الحريق من اختلاف في المدلول وإن كان مآل المدلولين واحدا. وهذا ضرب من من من المغايرة

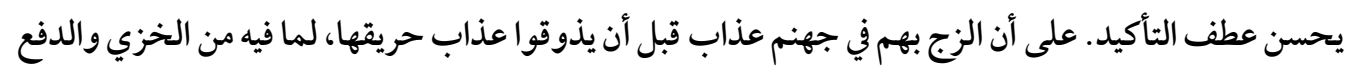

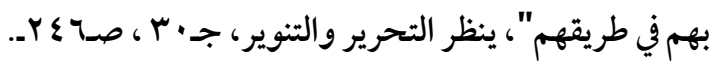

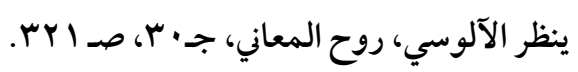




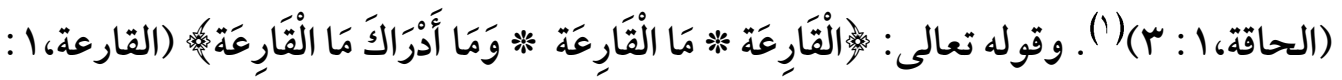

$(r)(r$

\section{- القسم الخامس:}

حيث يتألف المقطع من أربعة أسطر يشير السطران الأخيران فيها إلى السطرين الأولين

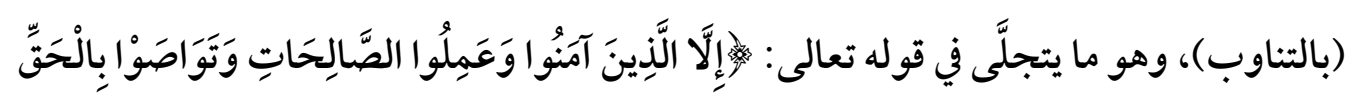

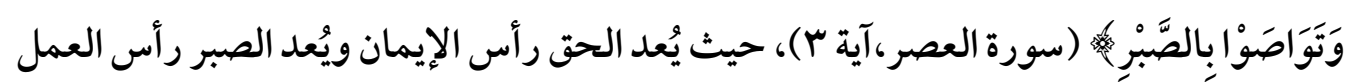

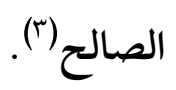
وكما هي الحال في أمر التناظرية التقابلية هنالك ثلاث ملاحظات بارزة تلخص الفوارق بين تجليات التناظرية الترادفية في التوراة والقرآن.

الملاحظة الأولى: أن تقسيمات “روبرت لوث” لأنماط الترادف وأشكاله اكتفت بالوصف الشكلي للأقسام المتغايرة دون أن تحمل تعليلا أو تفسيرا لأي من شواهد هذه الأنماط، في حين إن ألوان الترادف والتكرار في الدراسات القرآنية قد حملت تعليلات متعددة بعدد اختلاف الشواهد، حيث شُفعت المواقف القر آنية التي عبََّت عن هذه الألوان بقدر هائل من الرؤى التى التأويلية المرتكزة على السياق العقدي والتشريعي للتعبيرات المتناظرة من جانب والسياق

( (1) ينظر الزمخشري، الكشاف، حيث يقول في تفسير تكرار كلمة الحاقة وما بعدها: ": الحاقة ما هي، أي أي

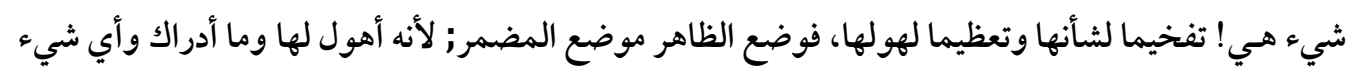
أعلمك ما الحاقة، يعني: أنك لا علم لك بكنهها ومدى عظمها، على أنه من العظم والشدة بحيث لا لا يبلغه دراية

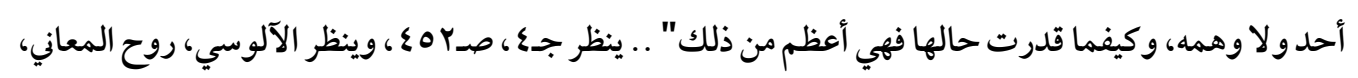

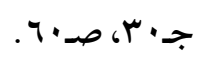

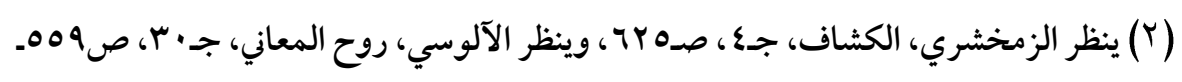

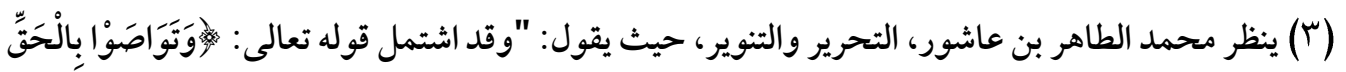

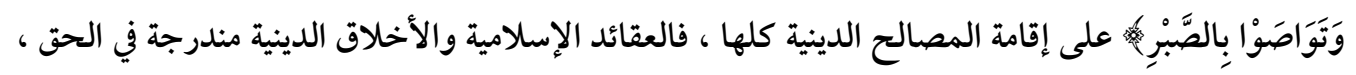

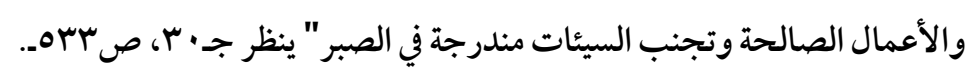


اللغوي والأدبي للسان العربي من جانب آخر، وتكفي قراءة سريعة لعناوين المصنفات التي رصدها أصحابها لدر اسة أساليب الترادف والتكرار في القرآن الكريم للتأكيد على هذه الحقيقة، حيث أفصحت هذه العناوين عن العلل الفكرية والأسرار الفنية التي تقف وراء اختلاف هذه الأساليب، ومثال ذلك كتاب "درة التنزيل وغرة التأويل في بيان الآيات المتشابهات في كتاب الله

العزيز" للخطيب الإسكافي (أبو عبد الله محمد بن عبد الله المتوفى · ؟ هـ )، و"البرهان في توجيه

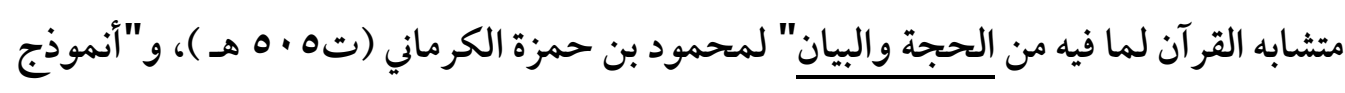
جليل في أسئلة وأجوبة عن غرائب التنزيل" لزين الدين محمد بن أبي بكر بن عبد القادر الرازي المتوفى 747ه، و"ملاك التأويل القاطع بذوي الإلحاد والتعطيل في توجيه متشابه اللفظ من آي التنزيل" لإبراهيم بن الزبير الغرناطي (ت1 • V هـ )، و"كشف المعاني في متشابه المثاني" لأبي عبد الله محمد بن إبراهيم بن جماعة (ت ل ع هـ )، و"الروض الريان في أسئلة القرآن" لشرف الدين بن ريان المتوفى · VVV، و"بصائر ذوي التمييز في لطائف الكتاب العزيز" لمجد الدين محمد بن يعقوب الفيروزابادي المتوفى IVهـ، و"مراصد المُطالع في تناسب المقاطع والمَطالع" و"قطف الأزهار في كشف الأسرار" لجلال الدين السيوطي (ت 911 هـ )، و"فتح الرحمن بكشف ما يلتبس في القرآن" لشيح الإسلام زكريا الأنصاري المتوفى7 9 هـ ) وغيرها، ولم تكتف هذه المصنفات بالتسميات، حيث صَدَّقت الدراسات المدونة بها على التوجه المنهجي المشار إليه في العناوين، فكان لكل ترادف وتشابه وتكرار على المستوى الشكلي اللفظي علته على المستوى المعنوي والفكري. الملاحظة الثانية: أن ظواهر الترادف التي أبرزها “روبرت لوث” في العهد القديم وقفت عند مستوى الكلمات أو العبارات المتجاورة، وهو ما تجاوزته الدراسات القرآنية التي اتسعت لتتناول الترادف على مستوى الكلمات أو الجمل غير المتجاورة .. أما فيما يتعلق بالكلمات فقد توَّجت دراسة د. فاضل صالح السامرائي (بلاغة الكلمة في التعبير القرآي) تاريخاطويلا من جهود دارسي الكلمات المتشابهة في النص القر آني، حيث جمعت الدراسة عددا هائلا من هذه الثنائيات 


\section{الإجلد الثامن والثلاثون إصدار يونيو.r.r.}

المنتثرة في الكتاب الكريم مثل: "الغيث" و"المطر" أو "الابن" و"الولد" أو "الأب" و"الوالد" أو"تنزل" وتتنزل" أو"توفاهم" و"تتوفاهم" أو"نبغ" و"نبغي" ( )، أما فيما يتعلق بالجمل فقد تعددت مواضع الترادف بين الجملتين غير المتجاورتين في كتاب الله الكريم، ورصدت الدراسات القر آنية هذه المواضع على اتساع النص القرآني، كما هو الثأن بين قوله تعالى في سورة

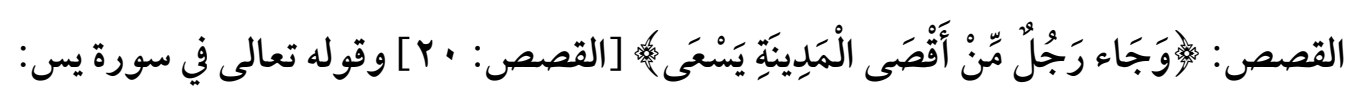

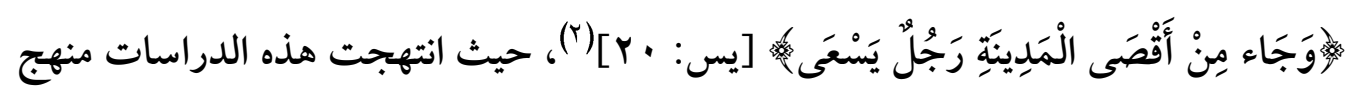
المقارنات السياقية التي تشعبت تجلياتها بين أسباب النزول وأحوال المخاطَين تارة، وبين الاختلافات التركيبية والصرفية في الفضاء اللغوي المحيط بالجملتين المتناظرتين تارة أخرى، وحاز قصب السبق في هذا النهج الكرماني في أسرا ر التكرار والغرناطي في ملاك التأويل .. الملاحظة الثالثة: وقفت ظواهر التوازي الترادفي في دراسات روبرت لوث عند مستوى الكلمتين والجملتين في حين تجاوزت الدراسات القرآنية هذا المستوى لتتناول الترادف على مستوى السورة، ثم الترادف على مستوى جملة النص، وهو ما ستتناوله الدراسة فيما يلي:

\section{- التناظرية الترادفية على مستوى الكلمة والعبارة :} يتسع الفارق بين معالجة محاضرات روبرت لوث للضرب المتعلق بظواهر التوازي الترادفي على مستوى الكلمتين المترادفتين في الشعر العبري المقدس ومعالجة الدراسات القرآنية له، حيث تقف معالجة روبرت لوث عند الاعتقاد الجازم بوقوع الترادف الذي يعني استواء المعنى بين اللفظين المترادفين، في حين تبدأ الدراسات القر آنية من الاعتقاد باستحالة الترادف التام بين هذه الألفاظ المتناظرة، ومن ثم راح الدارسون يسوّدون آلاف الصفحات في استكناه

( ( ) ينظر فاضل صالح السامر ائي، بلاغة الكلمة في التعبير القر آني، مكتبة العاتك، القاهرة، الطبعة الثانية، YY ؟ اهـ . $r \cdots t$

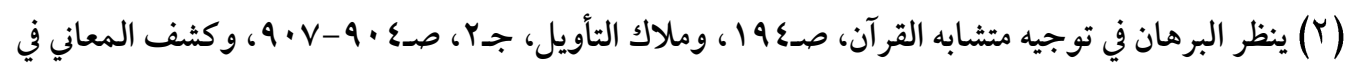

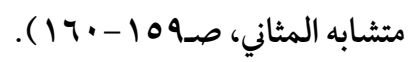


الاختلافات الدقيقة بين اللفظتين، وتأسست خطط المصنفات التي تناولت ظواهر الترادف القر آني على تبيان الفوارق الدقيقة بين الكلمات التي (تبدو) مترادفة لكنها تنطوي على اختلافات لغوية وسياقية تفصح عن الملامح الدقيقة للقيم الجمالية التي من شأنها أن تبرز ملامح التفرد في

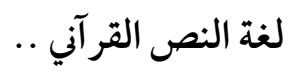

وتكفي مطالعة عَجِلَةُ للمواقف القر آنية التي بسطتها المصنفات المذكورة سابقا - ولا تتسع الدراسة لإحصائها - في تأكيد هذا المنزع المنهجي في دراسة متشابهات القرآن الكريم .. - التناظرية التزادفية على مستوى السورة :

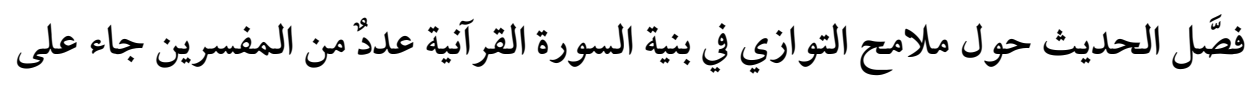
رأسهم الإمام فخر الدين الرازي (تج + ج هـ ) (') في كتابه "التفسير الكبير"، وأحمد بن إبراهيم الغرناطي (ت^ • V هـ ) في كتابه "البرهان في مناسبة ترتيب سور القرآن"(؟)، وبرهان الدين

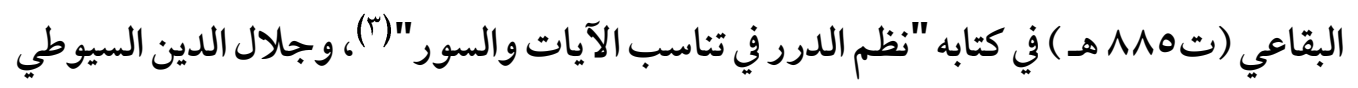
(ت 1 هـ ) في كتابيه "أسرار التنزيل" المسمى "قطف الأزهار في كثف الأسرار"((؛)، و"تناسق

( () الفخر الرازي (الإمام محمد فخر الدين بن ضياء الدين عمر المتوفى ؟ ـ ج هـ )، تفسير الفخر الرازي المسمى

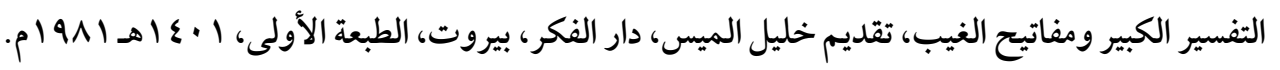

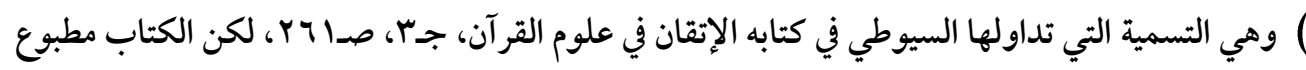
باسم البرهان في ترتيب سور القرآن، بتحقيق محمد شعباني، الناشر وزارة الأوقاف والشئون الإسلامية بالمملكة

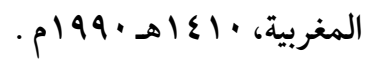
(广ّ) خرَّج آياته وأحاديثه ووضع حواشيه عبد الرزاق غالب المهدي، دار الكتب العلمية، بيروت، الطبعة الأولى، . 1 . 1 إ وهو لا يزال مخطوطا ينظر حاجي خليفة، كثف الظنون عن أسامي الكتب والفنون، تحقيق مصطفى بن

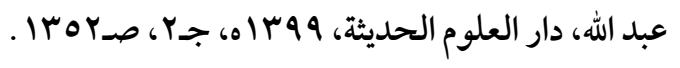




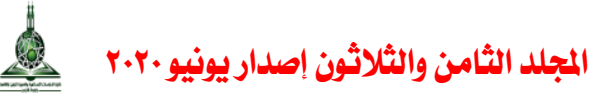

الدرر في نظم الآيات والسور"(() و"مر اصد المطالع في تناسب المقاطع والمطالع"(ז)، وأخيرا

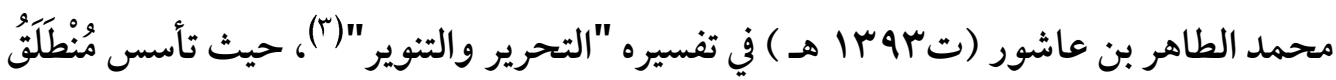
هؤلاء العلماء الأجلاء على أن السورة القرآنية تنبني على تناسب مطرد بين أول السورة وآخرها، أو - وفق تعبير السيوطي - بين مطلعها ومقطعها، وهو ما يتجلَّلى فيما يلي:

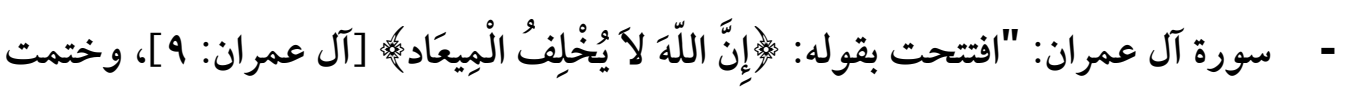

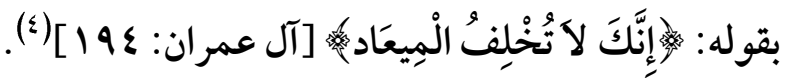

- سورة النساء: "فتحت بأحكام المواريث والكلالة وختمت بمثل ذلك"(؛). - سورة المائدة: "بدئت بتحريم الصيد في الإحرام وبالشهر الحرام والهدي والقلائد وختمت

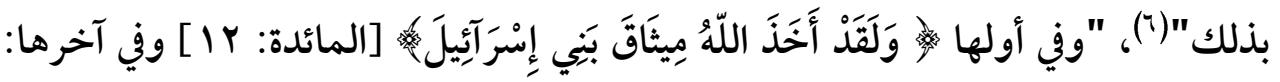

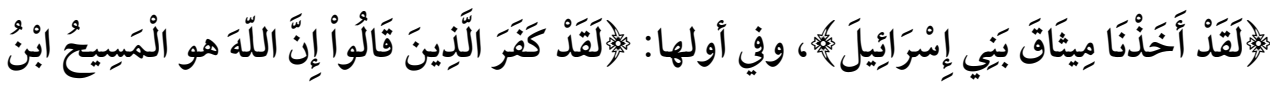

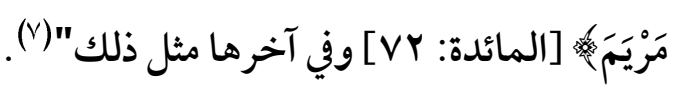

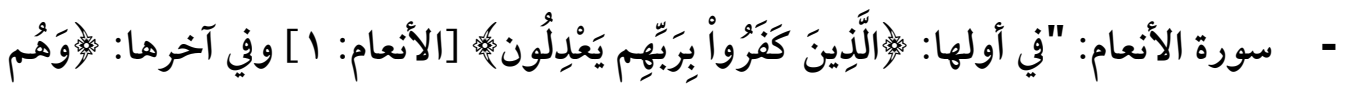

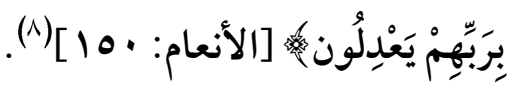

( (1) تحقيق عبد القادر أحمد عطا، دار الكتب العلمية، بيروت، الطبعة الأولى، 4 · ـ اهـ ـ.

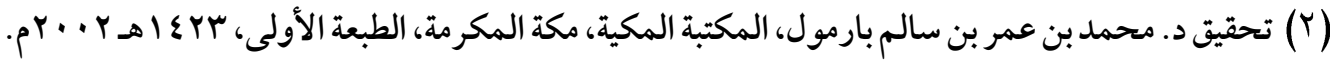
(Y) محمد الطاهر بن محمد بن محمد الطاهر بن عاشور التونسي، تحرير المعنى السديد وتنوير العقل الجديد

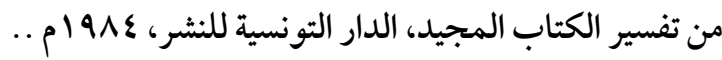

$$
\begin{aligned}
& \text { (8) مراصد المطالع، صدV I I I I . }
\end{aligned}
$$

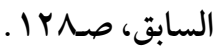

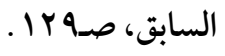

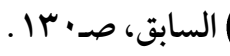

$$
\begin{aligned}
& \text { (1) السابق، صـ·r إ. }
\end{aligned}
$$




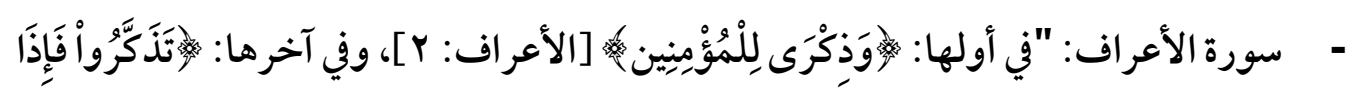

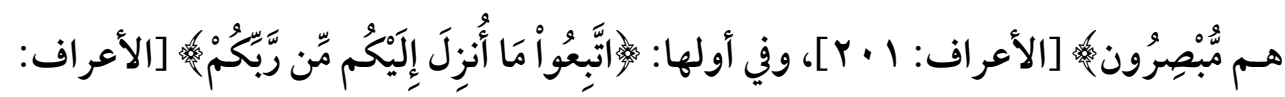

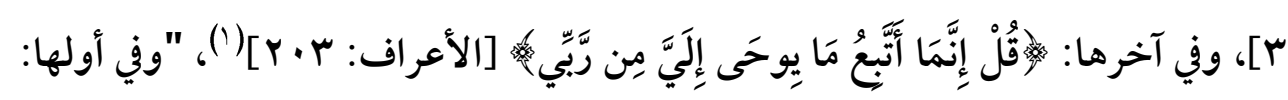

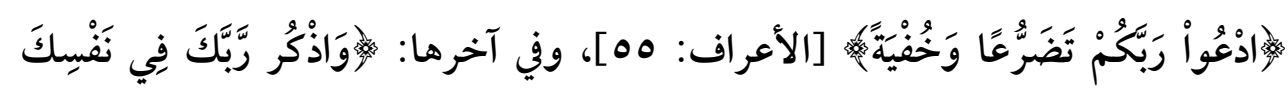

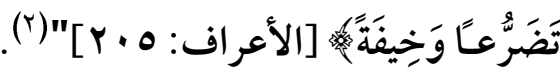

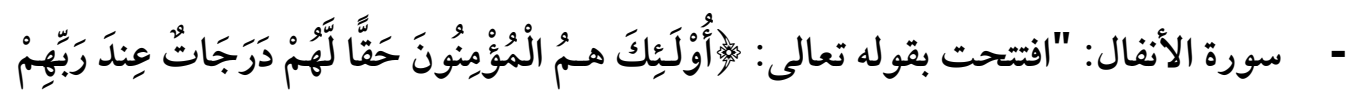

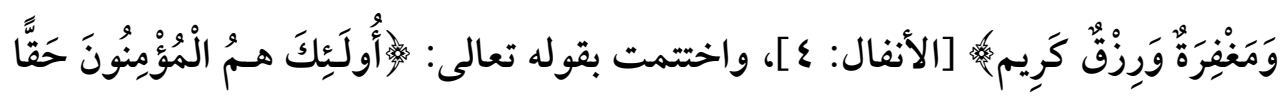

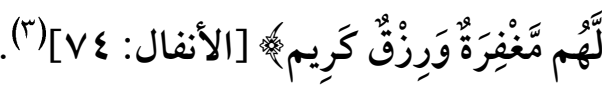

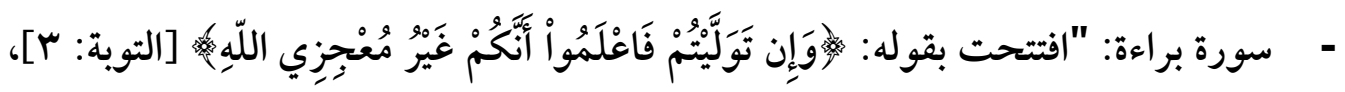

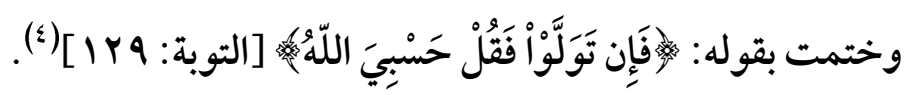

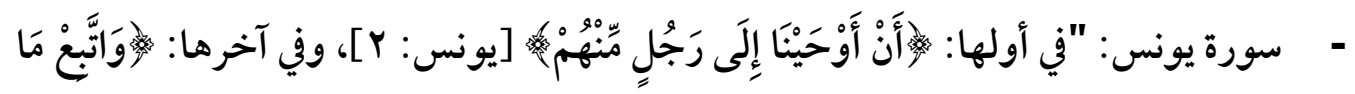

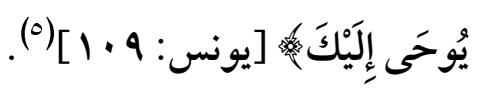
- سور هود ويوسف والرعد وإبر اهيم والحجر : "كلها مفتتحة بذكر القر آن مختمة به"(). - سورة الإسراء: "افتتحت بالتسبيح وختمت بالتحميد"(vوال.

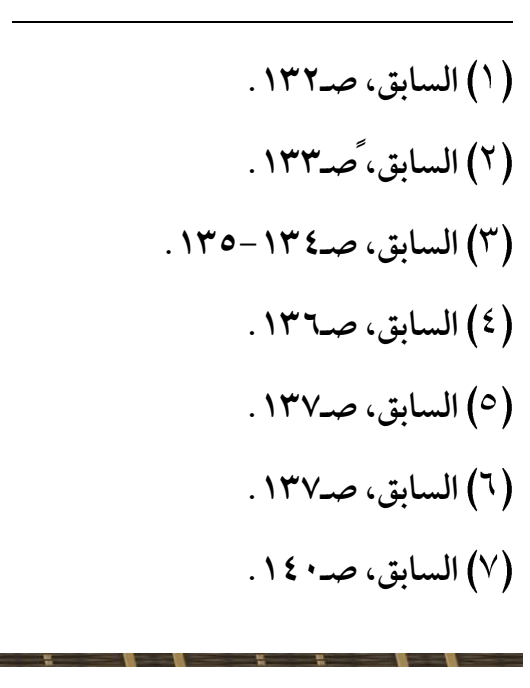


- سور الكهف ومريم وطه: "كلها مفتتحة بذكر القرآن والذكر ومختتمة به"( ).

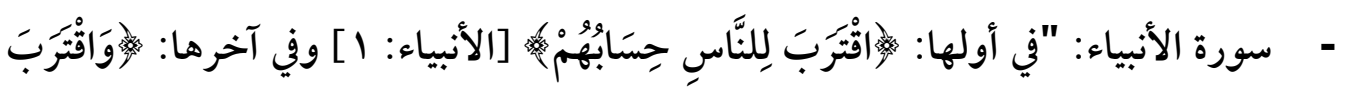

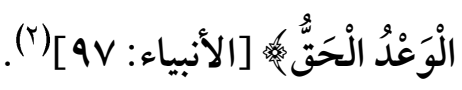

- سورة الحج: بدئت بذكر الساعة وختمت بذكر أحوالها من شهادة الرسول على المسلمين

وشهادة المسلمين على الناس(r).

- سورة الفرقان: "بدئت بتبارك وختمت بذلك"(£).

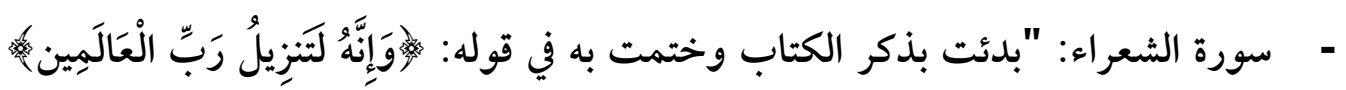

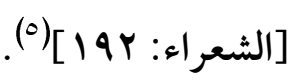

- سورة النمل: بدئت بذكر الكتاب ... وختمت بذلك"(؟).

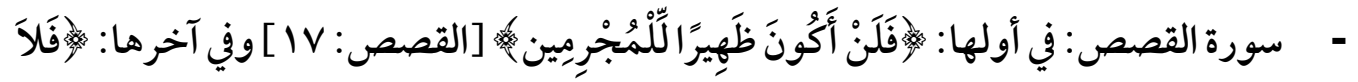

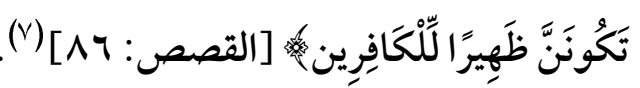
- سورة العنكبوت: بدأت بذكر ابتلاء المؤمنين وفتنتهم وانتهت بالسبل التي حددها القرآن

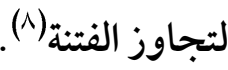

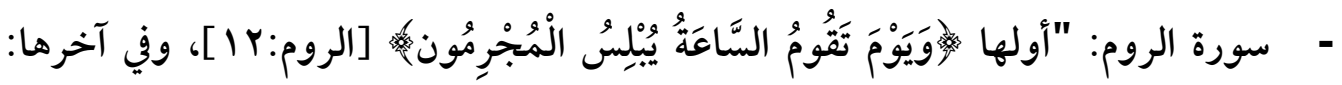

$$
\begin{aligned}
& \text { (1) السابق، صـ• } 1 \text {. } \\
& \text { (Y) السابق، صـاء ا. . } \\
& \text { (r) السابق، صـاء } 1 .
\end{aligned}
$$

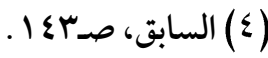

$$
\begin{aligned}
& \text { (0) السابق، صد؟ } 1 .
\end{aligned}
$$

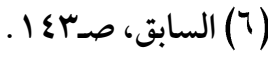

$$
\begin{aligned}
& \text { (V) السابق، صـ؛ } 1 \text {. . } \\
& \text { (^) السابق، صده } 1 .
\end{aligned}
$$




\section{فرائد البنية التناظرية في النصالقرآني (دراسة أسلوبية إحصائية مقارئة)

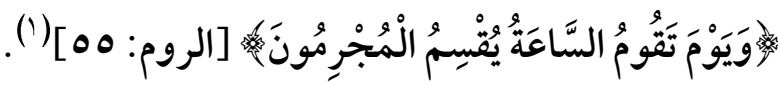

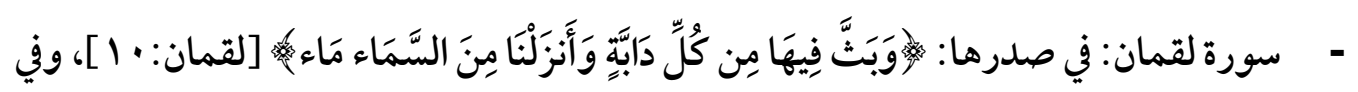

$$
\text { آخرها: }
$$

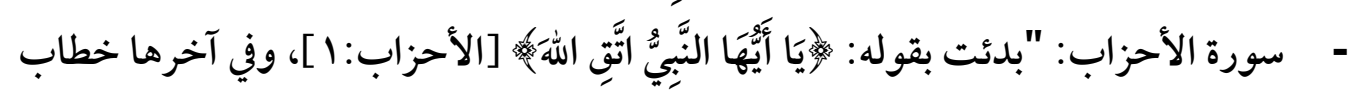

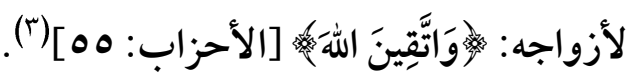

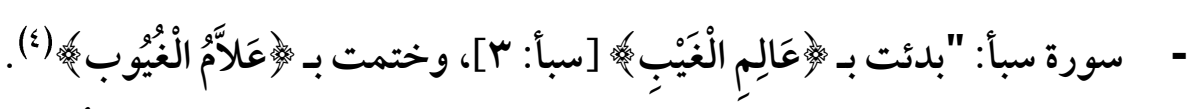

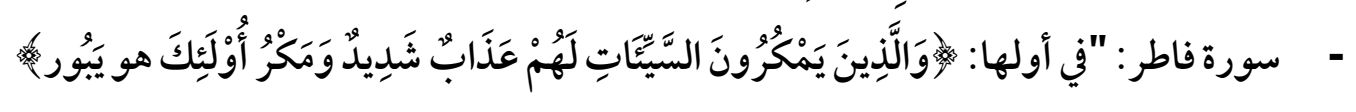

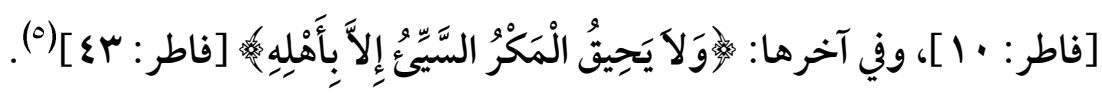

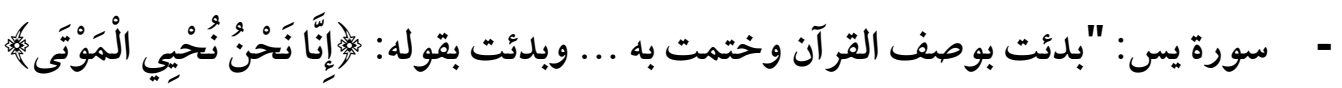

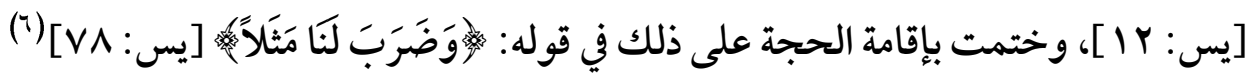

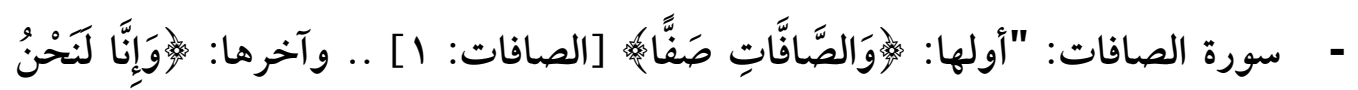

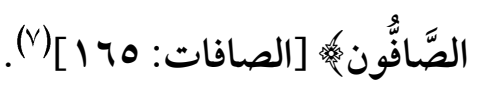

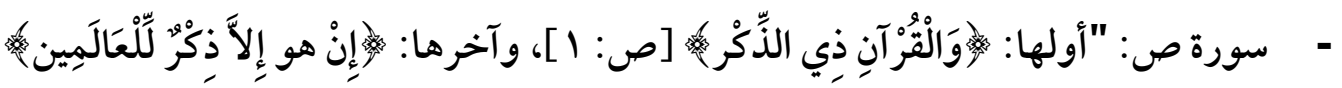
${ }^{(\Lambda)}[\wedge \vee: ص]$

\begin{tabular}{|c|}
\hline ( () السابق، صده ع 1. \\
\hline (Y) السابق، صده § ا-7 1 ـ . \\
\hline (r) السابق، صد § 1 . \\
\hline ( §) السابق، صـ § 1 . \\
\hline (0) السابق، صـV \& I . \\
\hline 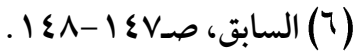 \\
\hline (V) السايق، صــ ا . \\
\hline (^) السابق، صـ9 § ا . \\
\hline
\end{tabular}




\section{المجلد الثامن والثلاثون إصدار يونيو.r.r.}

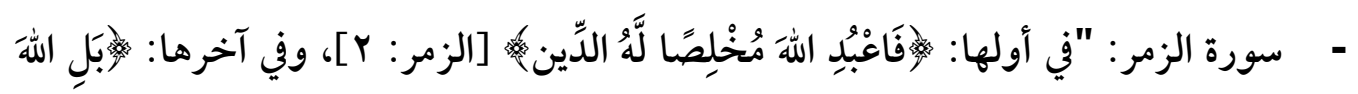

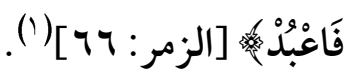

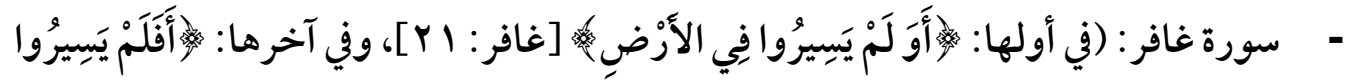

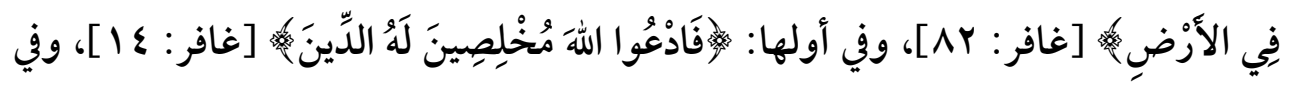

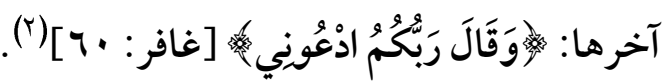

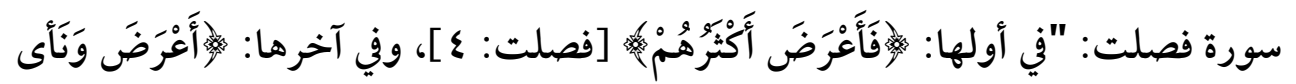

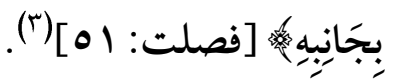

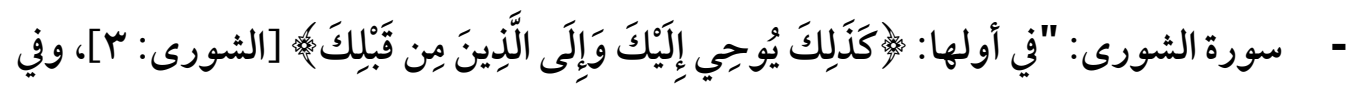

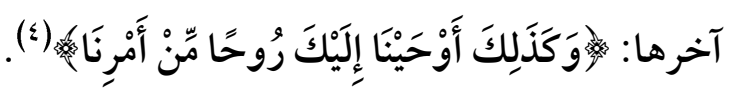

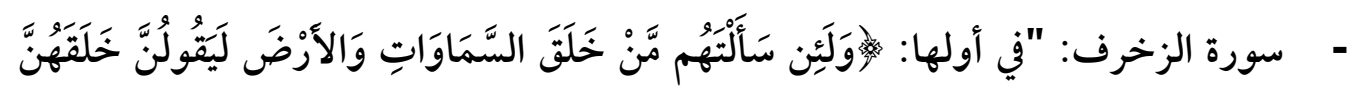

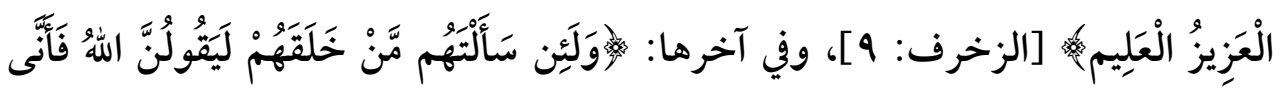

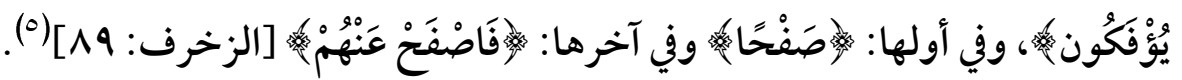

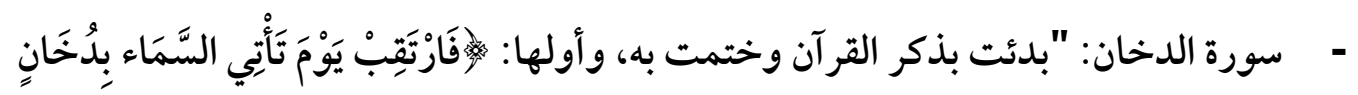

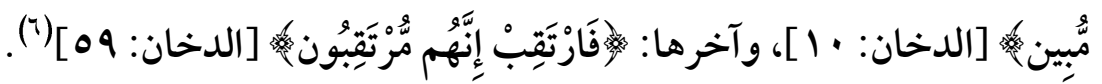

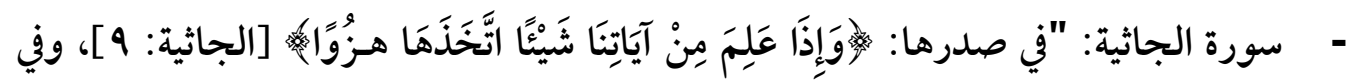

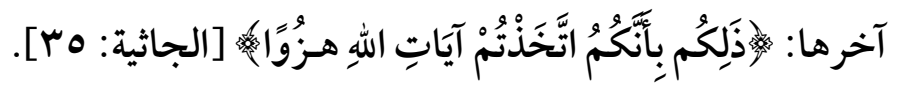

$$
\begin{aligned}
& \text { (1) السابق، صهو 1. } \\
& \text { (Y) السابق، صـ101. } \\
& \text { (") السابق، صـا } 101 . \\
& \text { (؛) السابق، صמ } 10 \text {. } \\
& \text { (0) السابق، صמمان. } \\
& \text { (1) السابق، صدها } 10 .
\end{aligned}
$$


- سورة الأحقاف: "بدئت بذكر خلق السماوات والأرض، وختمت به"( ).

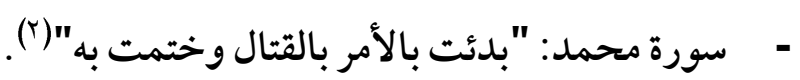
- سورة الفتح: "بدئت بوصف النبي - صلى الله عليه وسلم - والمؤمنين وما وعدوه، وختمت بذلك"(r).

- سور الحجرات: "بدئت بوصف الله سبحانه بالعلم وختمت بمثل ذلك، وبدئت بذكر

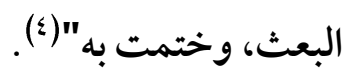

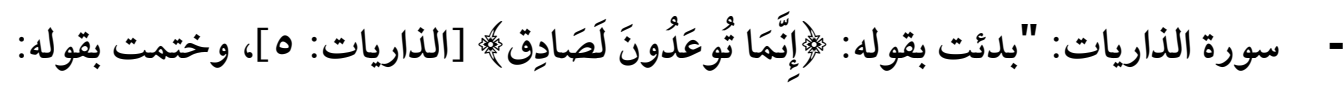

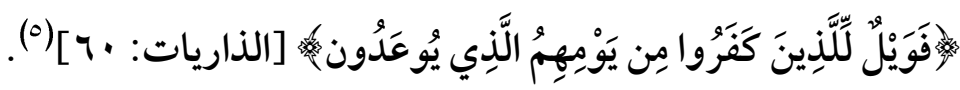

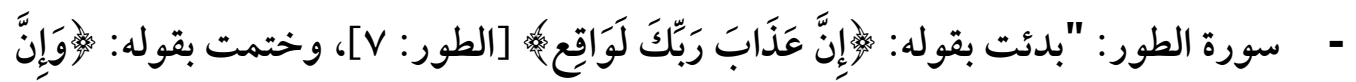

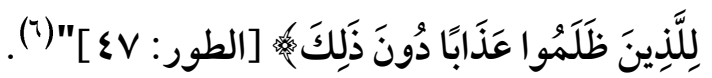
- سورة النجم: بدئت بذكر نجم (هو الثريا)، وختمت بذكر نجم هو الشعرى(V).

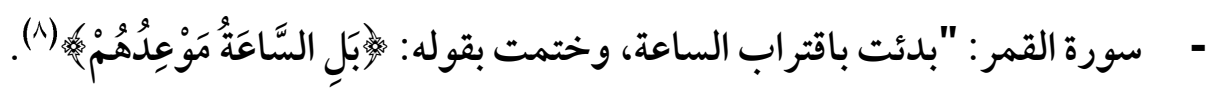

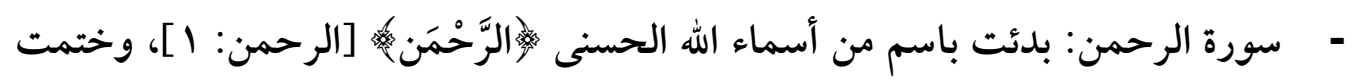

$$
\begin{aligned}
& \text { (1) السابق، صدبه } 1 \text {. } \\
& \text { (r) السابق، صــ } 10 . \\
& \text { (r) السابق، صد100. } \\
& \text { (£) السابق، صد100. } \\
& \text { (0) السابق، صـالـ } 107 . \\
& \text { (T) السابق، صـV } 10 \text {. } \\
& \text { (V) السابق، صـ10V. } \\
& \text { (^) السابق، صـ101. }
\end{aligned}
$$


المجلد الثامن والثلاثون إصدار يونيو.r.r.

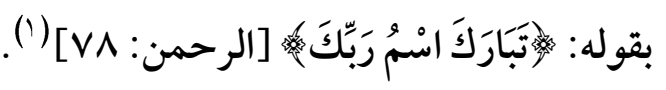
- سورة الواقعة: "صُدِّرت بذكر أزواج الخلق الثلاثة: أصحاب الميمنة وأصحاب المشأمة

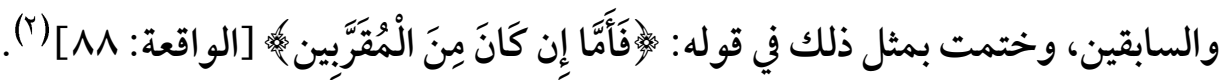

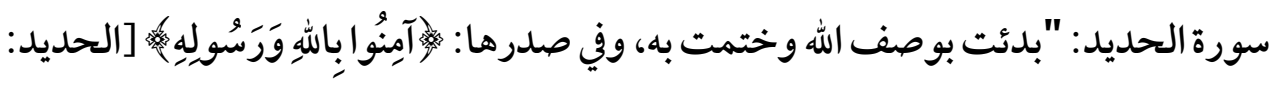
[V آخرها ذكر النور"(r).

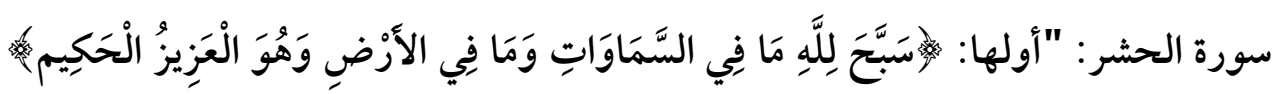

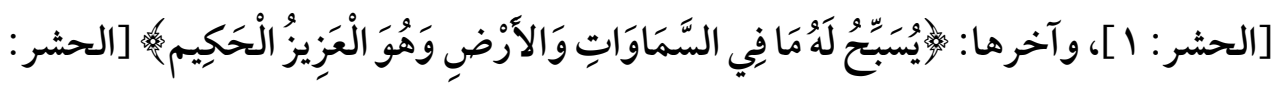
(घ) $[Y \varepsilon$

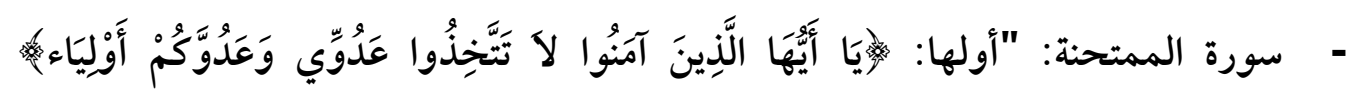
[الممتحنة: ا ]، وآخرها:

.$^{(0)}[\mathrm{Ir}$

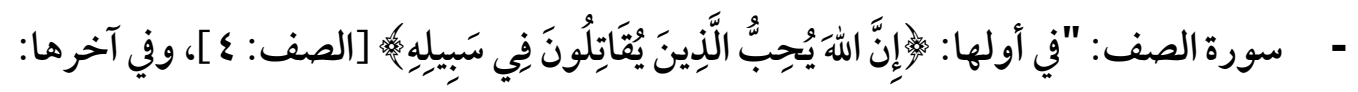

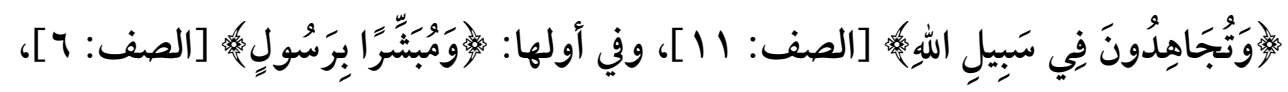

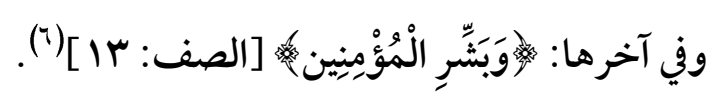

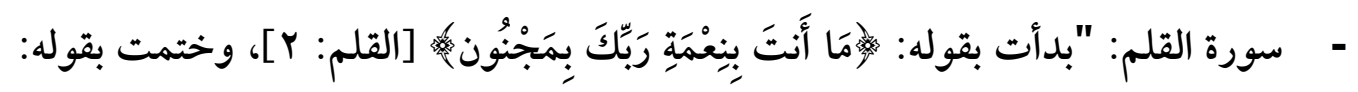

$$
\begin{aligned}
& \text { ( ) السابق، صـه1 ا . } \\
& \text { (Y) السابق، صـ101. }
\end{aligned}
$$

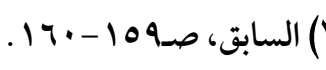

$$
\begin{aligned}
& \text { السابق، صـ. 17 - 1 ال1 1. } \\
& \text { (0) السابق، صـال } 17 \text {. } \\
& \text { السابق، صـ|7 | 1 - } 17 \mid
\end{aligned}
$$


برائية

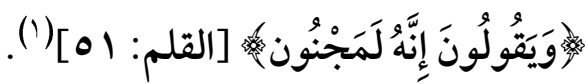

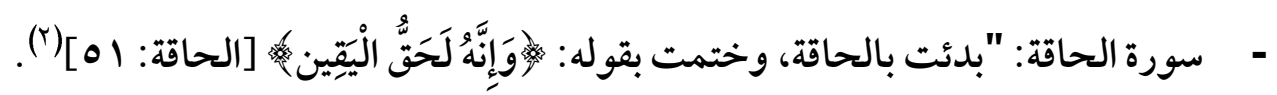
- سورة المعارج: "بدئت بالوعد يوم القيامة، وختمت به"("). - سورة نوح: "بدئت بالوعيد بالعذاب الأليم، وختمت به"(؛). - سورة الجن: "بدئت بالجن وختمت بذكره"(•).

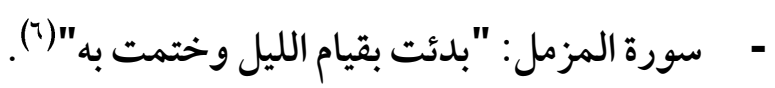
- سورة المدثر : "بدئت بالإنذار وختمت به"(V). - سورة القيامة: "بدئت بذكر الإعادة وإحياء الموتى وختمت بذلك"(^). - سورة النبأ: بدئت بالوعيد باليوم الآخر وختمت بالإنذار من عذاب الآخرة(9).

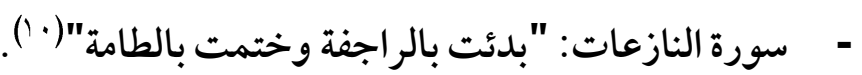

- سورة المطففين: بدئت بوعيد المطففين وختمت بنفي المثوبة عن الكافرين(').

\begin{tabular}{|c|}
\hline (1) السابق، صد9 1 . \\
\hline (Y) السابق، صـ9 1 . . \\
\hline (T) السابق، صـ97 ا - • IV . \\
\hline 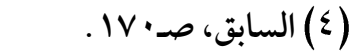 \\
\hline (0) السابق، صد· IV . \\
\hline (T) السابق، صـIVI IV \\
\hline IVI السابق، صـ (V) . \\
\hline (^) السابق، صدY IVY. \\
\hline (9) السابق، صدץl IV . \\
\hline ( • () السابق، صدس IVr . \\
\hline (1 (1) السابق، صده IV . \\
\hline
\end{tabular}


- سورة الانشقاق: بدئت بذكر السماء وختمت بالإشارة إليها(').

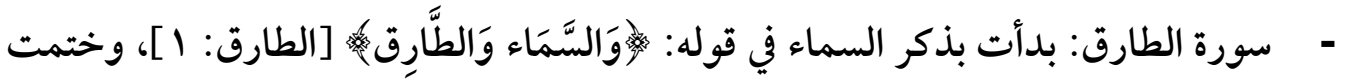

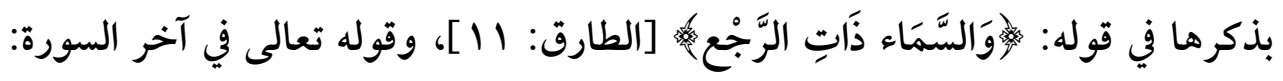

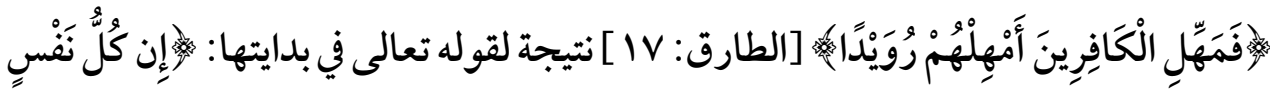

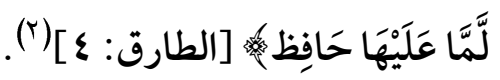
- سورة الغاشية: بدئت بالإشارة إلى اليوم الآخر (حديث الغاشية)، وختمت بالإشارة إلى

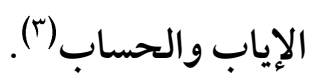

-

- سورة الضحى: بدئت بذكر نعم الله تعالى، وختمت بالأمر بالتحدث بهذه النعم (). - سورة الشرح: بدئت بالحديث عن نعم الله تعالى على رسوله - صلى الله عليه وسلم وختمت بأمر الله رسوله - صلى الله عليه وسلم - بشكر هذه النعم(").

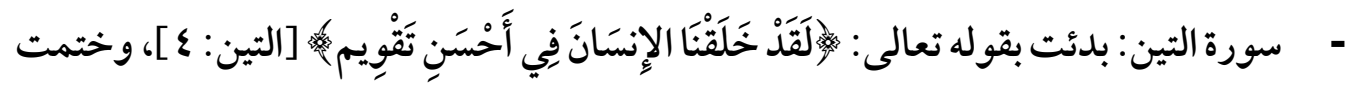

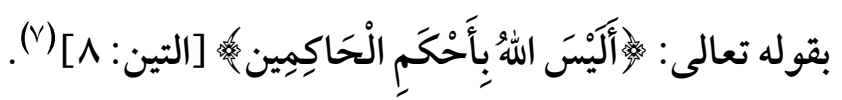
- سورة البينة: بدئت بذكر حضور البينة حجة على أهل الكتاب، وختمت بانقسامهم حيالها

$$
\begin{aligned}
& \text { (1) السابق، صده IV . } \\
& \text { (Y) نظم الدرر، جـ، صدץ·ـ . } \\
& \text { (r) مر اصد المطالع، صـIVV (I) }
\end{aligned}
$$

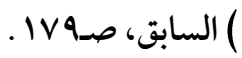

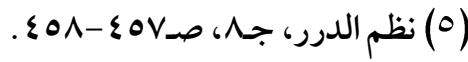

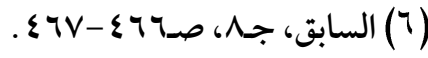

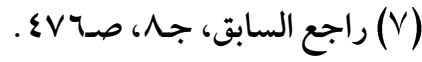




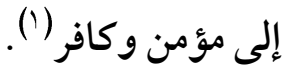

- سورة القارعة: بدئت بذكر القارعة، وختمت بذكر الهاوية(؟).

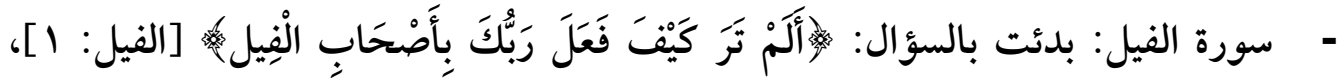

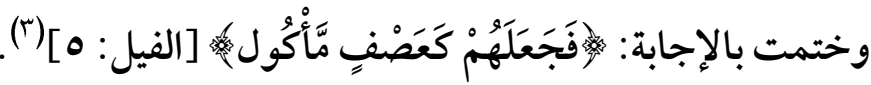

- سورة قريث: أول السورة علة لآخرها(؛). - سورة الماعون: بدئت بذكر المكذبين (الكافرين) وختمت بذكر المرائين (المنافقين).

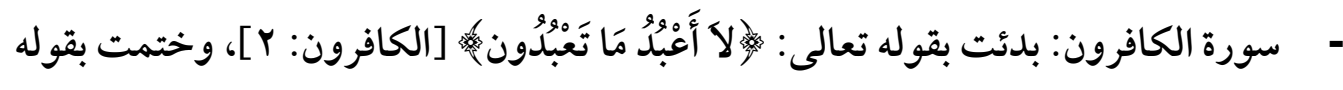

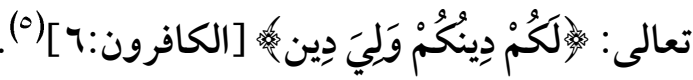
- سورة المسد: بدئت بحال أبي لهب وختمت بحال امر أثه(؟). - سورة الإخلاص: "مطلعها أحد ومقطعها أحد")(v) - سورة الفلق: بدأت بالاستعاذة من شر ما خلق الله تعالى، وختمت بذكر شر ما خلق (^). - سورة الناس: وقع الترادف في تكرار كلمة الناس في مطلعها ومقطعها معا(9).

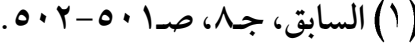

$$
\begin{aligned}
& \text { (Y) السابق، جم، صده } 01 . \\
& \text { (r) السابق، جـ، صدrهـ. } \\
& \text { (4) السابق، جـ، صـVrه. } \\
& \text { (0) السابق، جم، صـ100. }
\end{aligned}
$$

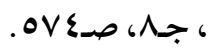

$$
\begin{aligned}
& \text { (V) مر اصد المطالع، صد IV (V) }
\end{aligned}
$$

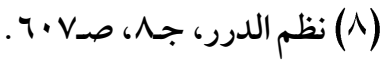

$$
\begin{aligned}
& \text { (q) مر اصد المطالع، صـ·11. }
\end{aligned}
$$




\section{- التناظرية الترادفية على مستوى النص :}

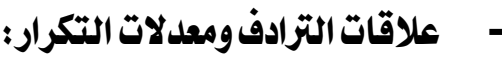

وإذا ما أردنا أن نؤسس للدراسة المقارنة في تناول البنية الكلية للنص المقدس سواء في القرآن الكريم أو التوراة من خلال التصور العام لعلم النص Science Du Texte بوصفه يقيم ما يتحصل عليه من نتاج بحثي على مجمل النص ولا يتوقف عند ما ينطوي عليه هذا النص من مفردات أو جمل أو فِقرات(').. فسوف نلاحظ - بوضوح - ملامح الترادف الكلي في بنية السورة القر آنية بين مفتتحها وخاتمتها، وكذلك ملامح الترادف الكلي في بنية النص القرآني من خلال التوافق السيمتري في عدد المترادفات القر آنية، حيث يتطابق تكرار الكلمات المترادفات في مجمل النص القرآني ليشكل بنية كلية متوازية على مستوى مجمل النص تحقق وجها أسلوبيا متفردا لا يتكرر في نصٍٍ آخر، كما في كلمتي الجحيم والعقاب، حيث تكررت كل كلمة بمشتقاتها المختلفة خمسة وعشرين مرة، أو في كلمات الأصنام والخمر والخنزير، حيث تكررت كل كلمة بواقع خمس مرات، أو في كلمتي الرجس والرجز، حيث تكررت كل كلمة بواقع عشر مرات، وكذا في كلمتي الطهر والإخلاص، حيث تكررت كل كلمة بواقع إحدى وثلاثين مرة، وكذا كلمتي الروح القدس ومحمد حيث تكررت كل كلمة بواقع أربع مرات، وكذا كلمتي رسالة وسورة ومشتقاتهما حيث تكررت كل كلمة بواقع عشر مرات، وكذا مشتقات السحر والفتنة حيث تكرر كل قسيم بواقع ستين مرة، وتكررت مشتقات البخل ومشتقات الحسرة بواقع اثنتى عشرة مرة لكل قسيم، وكذا تكررت مشتقات الطمع ومشتقات الجحود اثنتى عشرة مرة(؟).

( (1) ينظر روبرت دي بوجر اند، النص والخطاب والإجراء، ترجمة: تمام حسان، عالم الكتب، القاهرة، الطبعة

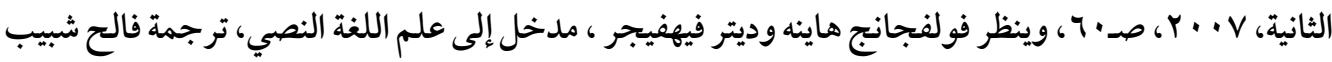
العجمي، جامعة الملك سعود، الرياض، 1999 امس، صده. (Y) ينظر في تفصيل هذه الأمثلة وغيرها كتاب الإعجاز العددي للقر آن الكريم، عبد الرزاق نوفل، دار الكتاب اللبناني، 1911، وقد اعتمد المؤلف على جهود سابقيه في حصر ألفاظ القرآن الكريم، حيث كان المستشرق 


\section{فرائد البنية التناظرية في النص القرآني (دراسة اسلوبية إحصائية مقارنة)}

وتتعدد القيم التأويلية للتكرار الترادفي بين هذه الكلمات، ومنها فيما يخص المثال الأخير أن كلمة الطهر تعبِّ عن نظافة الجسد المؤمن في حين إن الإخلاص يعبر عن نظافة الروح المؤمنة، حيث يمثلان معا نظافة الخارج و الداخل، وهو ما يتماهى مع مجمل الوصايا الإسلامية المتحققة

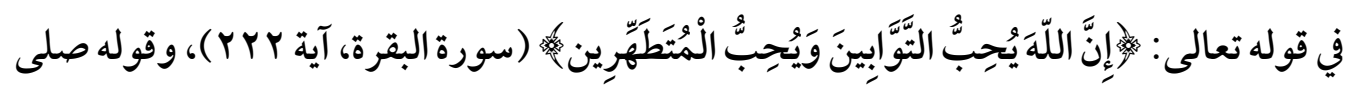
الله عليه وسلم: "الطهور شطر الإيمان"(1). وبوجه عام تتوزع هذه التجليات المختلفة للتوازي القرآني على مستوى مجمل النص بين ثلاثة متعلقات على الوجه التالي: - ما يتعلق بالعقائد وما يتصل بها من الفعل الإلهي، كما هي الحال في الإيمان بالتوحيد والكتب والرسل واليوم الآخر والقضاء والقدر خيره وشره و الغيب من الملائكة والشياطين. - ما يتعلق بالعبادات من الصلاة والزكاة والصيام والحج. - ما يتعلق بالتشريعات وما يتصل بها من السلوك البشري. وفيما يختص بالمتعلق الأول الخاص بالعقائد، وإذا بدأنا بعقيدة الإيمان بالكتب ترد متر ادفات القر آن والوحي والإسلام، والقرآن والمالئكة، وسور القرآن ورسالة الله، على الوجه التالي:

أولا : القرآن والوحي والإسلاه :

\begin{tabular}{|c|c|c|}
\hline (الإسلام) ؟ - الآيات: & (أوحينا) ع ا-الآيات: & (القرآن) بـ - الآيات: \\
\hline 1-[آل عمران: 19]، צ-[آل عمران: & 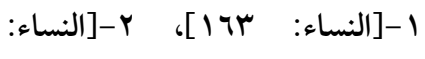 & 1-[البقرة: 1/10]، Y-[النساء: \\
\hline ه11]، r-[المائدة: ب[]، ع-[الصف: & rד 1]، r-[يونس: Y]، ع -[يوسف: & 1Ar]، r-[المائدة: 1+1]]، ع- \\
\hline.$[\mathrm{V}$ & r]، ه-[الرعد: ·r]، צ-[النحل: & [الأنعام: 19]، ه-[الأعراف: \\
\hline
\end{tabular}

الألماني فلوجل على رأسهم في كتابه المسمَّى "نجوم الفرقان في أطراف القر آن"، ثم كتاب محمد فؤاد عبد الباقي "المعجم المفهرس لألفاظ القرآن الكريم" المأخوذ من كتاب فلوجل المذكور. ( (1) ورد بلفظه في صحيح مسلم، ومسند أحمد بن حنبل، ومسند أبي نعيم، والسنن الكبرى للبيهقي، ومصنف ابن أبي شيبة، وغيرها. 
المجلد الثامن والثلاثون إصلار يونيو.r.r.

\begin{tabular}{|c|c|c|}
\hline (لإسلام) ب-الآيات: & 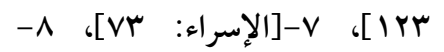 & ع \\
\hline 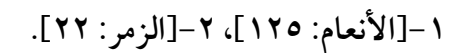 & 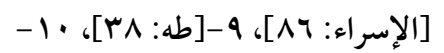 & [يوسف: r]، ^-[الحجر: 91]، \\
\hline (مسلمين) ^- الآيات: & [طه: & 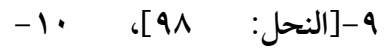 \\
\hline 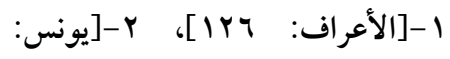 & [الشورى: VV]، سا -[الشورى: سا]، & [الإسراء: 9]، ال1الإسراء: \\
\hline 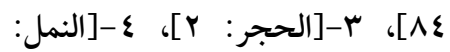 & ع ا - [الشورى: or]. & 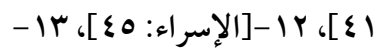 \\
\hline اسـ]، ه-[النمل: & (وأوحينا) ^-الآيات: & [الإسراء: ؟ج ]، ع 1-[الإسراء: \\
\hline ץ\&]، & 1-[النساء: سד1]، ץ-[الأعراف: & . 7]، 10 -[الإسراء: \\
\hline [الزخرف: 79]. & & 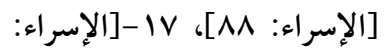 \\
\hline (مُسْلِمَيْن) ا-الآية: & [يونس: AN ]، ه-[يوسف: 010]، ج- & 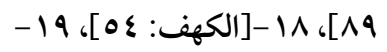 \\
\hline 1- & [الأنبياء: VY]، V-[الشعراء: OY]، & 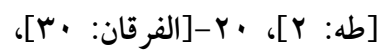 \\
\hline (المسلمين) || - الآيات: & ^-[القصص: V ]. & آr-[الفرقان: rr \\
\hline 1-[الأنعام: rד 1]، Y-[يونس: [VY]، & (فأوحينا) Y-الآيات: & [النمل: 1 ]، سץ-[النمل: צ]]، \\
\hline 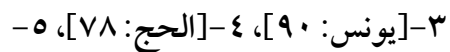 & 1-[المؤمنون: YV ]، Y- [الشعراء: & ع ץ-[النمل: ד־]، هץ-[النمل: \\
\hline [النمل: 91]، צ-[الأحزاب: هrr]، v- & אד [ ] & 9r]، \\
\hline 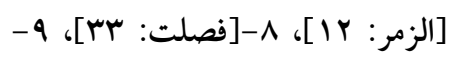 & 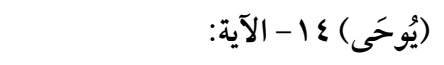 & 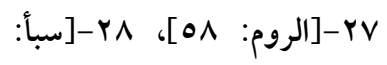 \\
\hline [الأحقاف: 10]، •ا-[الذاريات: & 1-[الأنعام: •0]، r-[الأعراف: & 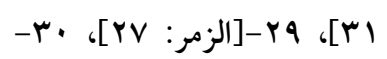 \\
\hline דr]، 11-[القلم: هr]. & 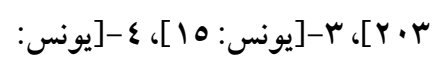 & [فصلت: צr]، اس-[الزخرف: \\
\hline (للمسلمين) Y-الآيات: & 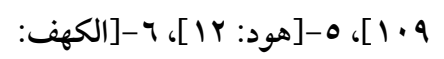 & اسr]، rr-rالأحقاف: : \\
\hline حل: & . & 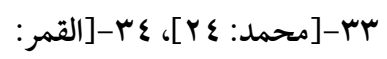 \\
\hline (مسلمون) ه 1 - الآيات: & 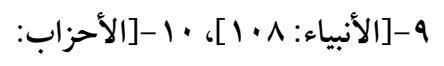 & IV]، هr-[القمر: r ] ]، צr- \\
\hline ו-[البقرة: ץr|]، צ-[البقرة: سrI]، & r]، ||-[ص: · · & [القمر: rr]]، \\
\hline r-[البقرة: צا1]، ع-[آل عمران: & 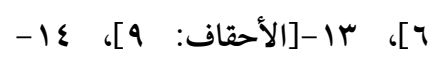 & 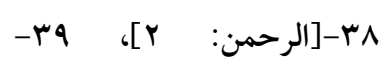 \\
\hline צor]، ه-[آل عمران: \&ד]، צ-[آل & [النجم: ع ]. & [الحشر: اYY]، •ع-[المزمل: \\
\hline 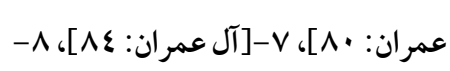 & (أُوحِيَ) 9-الآيات & 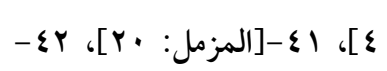 \\
\hline [آل عمران: r.1]، و-المائدة: & 1 - [الأنعام: به ] لا تحسب هذه المرة & [الإنسان: rr]، rع -[الانشقاق: \\
\hline 11]، & في الإحصاء لأنها تعبر عن الوحي & \\
\hline [الأنبياء: ^•1]، rا-1النمل: 11]، & المكذوب وهو ما يعني دقة القصدية & 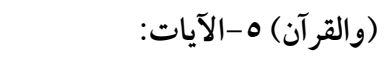 \\
\hline rا-[العنكبوت: צ؟]، \& ا-[الروم: & الترادفية في التناظر القرآني ب- & 1-[التوبة: 111]]، r-[الحجر: \\
\hline
\end{tabular}




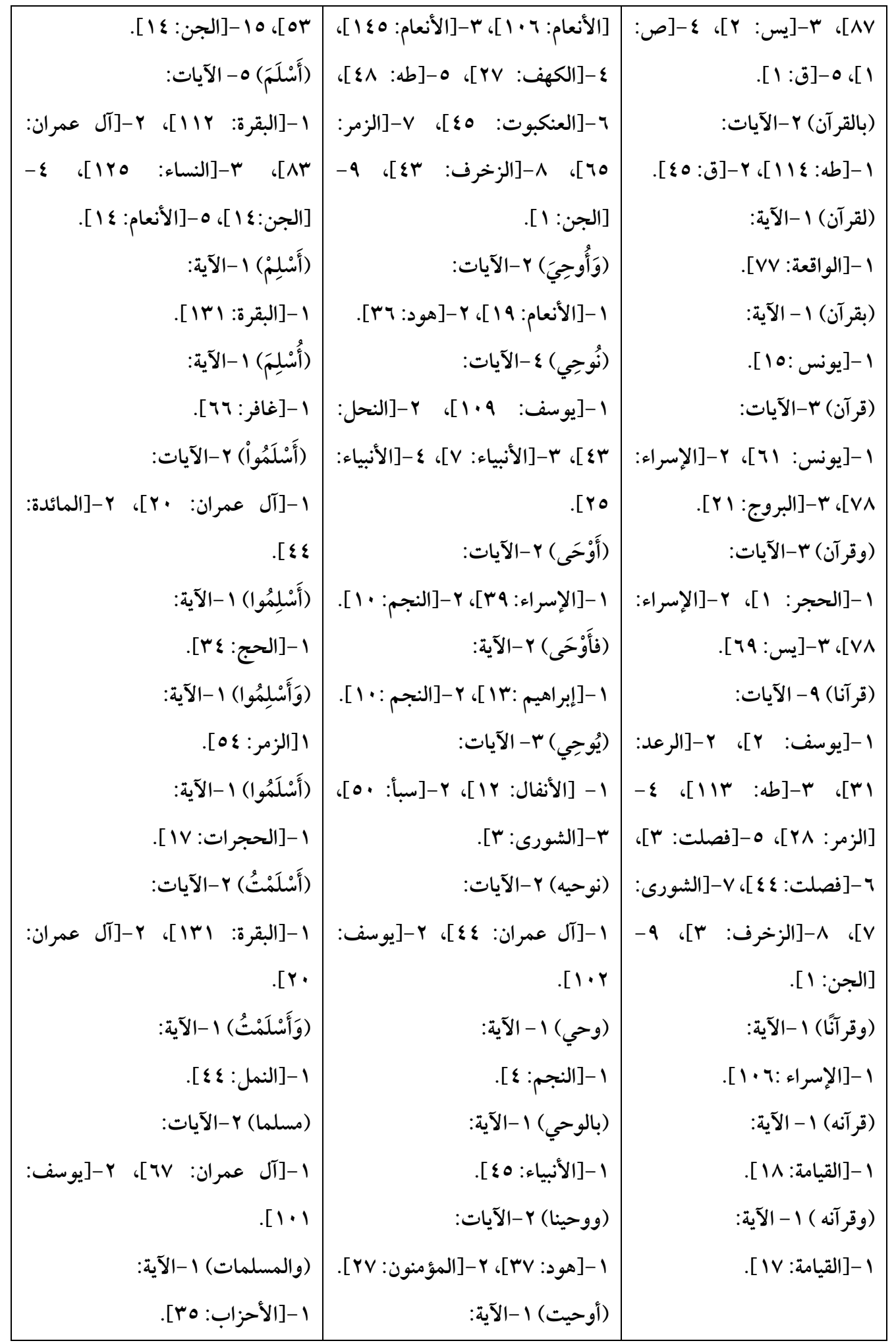


المجلد الثامن والثلاثون إصدار يونيو.r.r

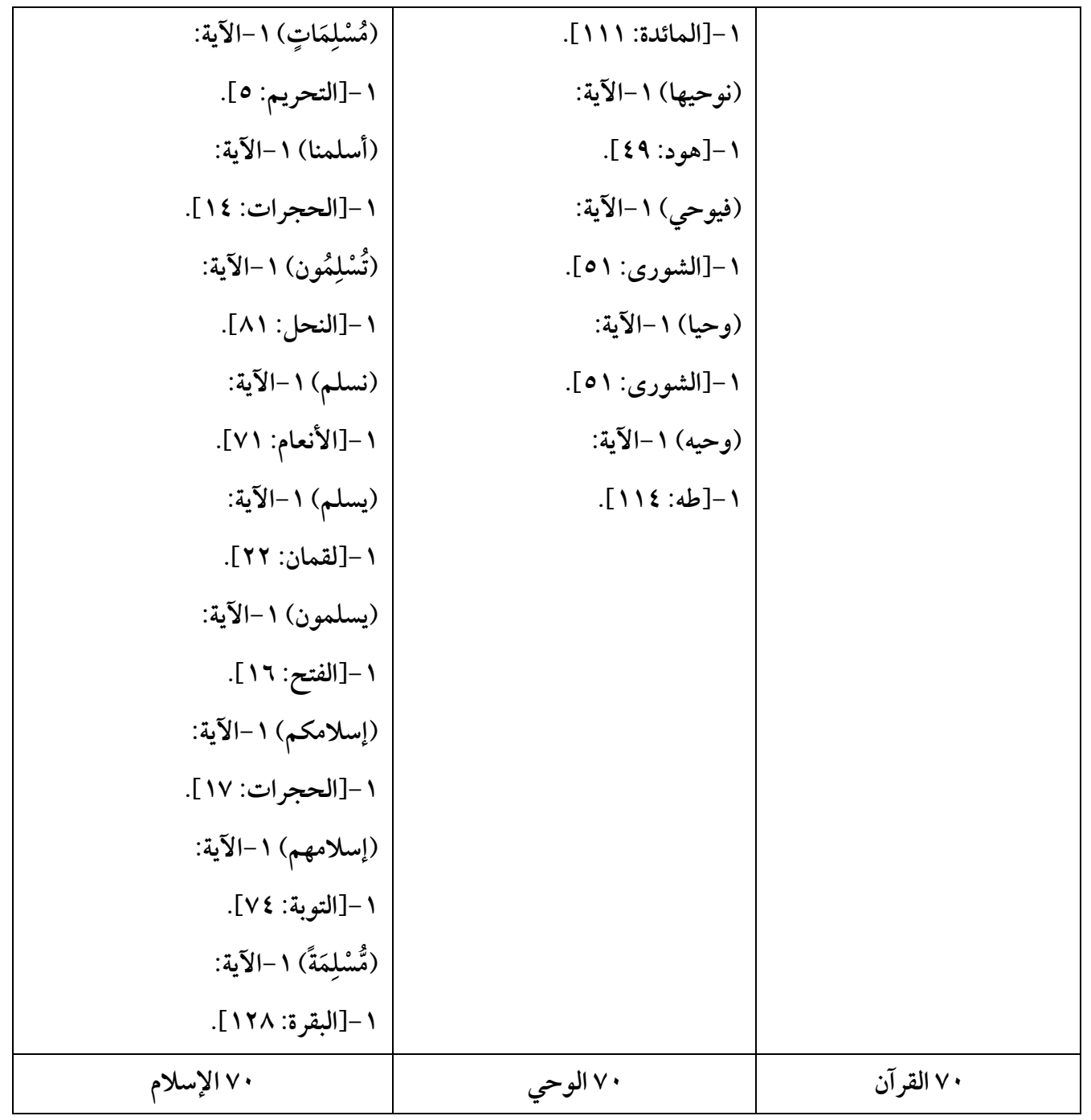

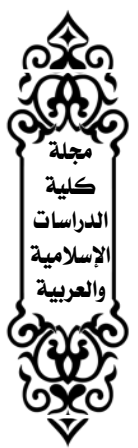

تخانيا : الطهارة والإخلاص :

$$
\text { (المخلصين) (الآيات: }
$$

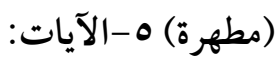

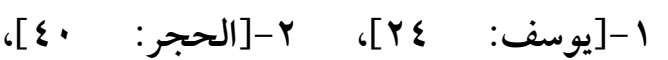

1-[البقرة:

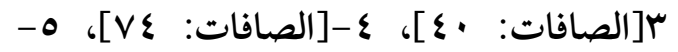

[ النساء: OV] ؛ ع - [عبس: \& I]]، ه-[البينة: Y].

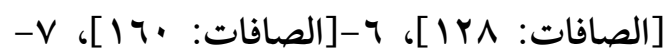

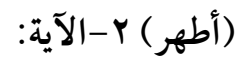

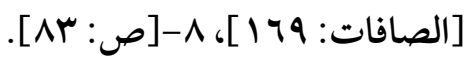

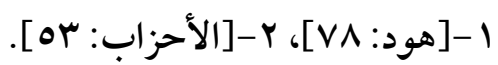

(مخلصين) V - V-الآيات:

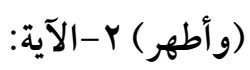

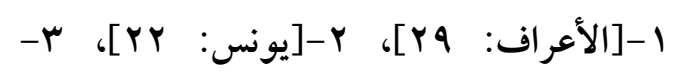

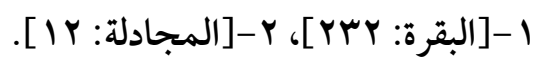




\begin{tabular}{|c|c|}
\hline [العنكبوت: 07]، ع -[لقمان: Yr]، ه-[غافر & (ليطهر كم) Y-الآية: \\
\hline ع 1]، ج-[غافر : 07]، V-[البينة: 0]. & 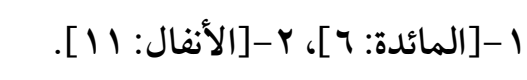 \\
\hline (خالصة) ؟-الآيات: & (ويطهر كم) ا-الآية: [الأحزاب: سr]. \\
\hline 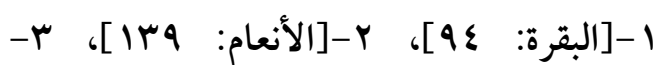 & (فطهر) ا -الآية: [المدثر: ع]. \\
\hline [الأعراف: rr]، ع-[الأحزاب: •0]. & (وطهر) ا-الآية: [الحج: דr]. \\
\hline (بخالصة) ا-الآية: [ص: ج؟ ]. & (يتطهرون) Y-الآيات: \\
\hline 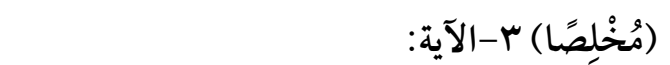 & 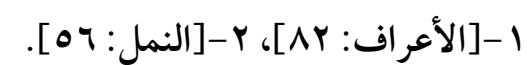 \\
\hline 1-[الزمر: r]، r-[الزمر: 11]]، r-[الزمر: \&1]]. & (طهورا) r-الآيات: \\
\hline (خلصوا) ا-الآية: [يوسف: •^]. & 1 \\
\hline (أخلصناهم) ا-الآية: [ص: ד؟ ]. & (يطهرن) ا-الآية: [البقرة: \\
\hline (وأخلصوا) ا -الآية: [النساء: جـ 1]. & (وطهرك) I - الآية: [آل عمران: Y ؟ ]. \\
\hline (استخلصه ) | -الاية: [يوسف: ؟ه ]. & (تطهرهم) ا -الآية: [التوبة: بـ1]]. \\
\hline (الخالص) ا-الآية: [الزمر: r]. & (يطهر) ا-الآية: [المائدة: 1؟]. \\
\hline (خالصا) ( -الآية: [النحل: צד]. & (طهرا) ا-الآية: [البقرة: 0YY]]. \\
\hline (مخلصون) ا-الآية: [البقرة: هس|]. & (تطهرن) ا-الآية: [البقرة: \\
\hline ) & (يتطهروا) ( - الآية: [التوبة: ^•1]]. \\
\hline & (فاطهروا) ا - الآية: [المائدة: ج]. \\
\hline & (تطهيرا) ( -الآية: [الأحزاب: سr]. \\
\hline & (ومطهرك) ( - الآية: [آل عمران: 00]. \\
\hline & (المطهرون) ا -الآية: [الواقعة: VVA]. \\
\hline & (المتطهرين) ا - الآية: [البقرة: Yry]. \\
\hline & (المطهرين) ا -الآية: [التوبة: 1 • 1]. \\
\hline 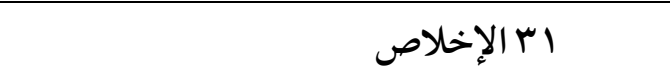 & مارة \\
\hline
\end{tabular}


ثالثا : رسالة الله وسور القرآن :

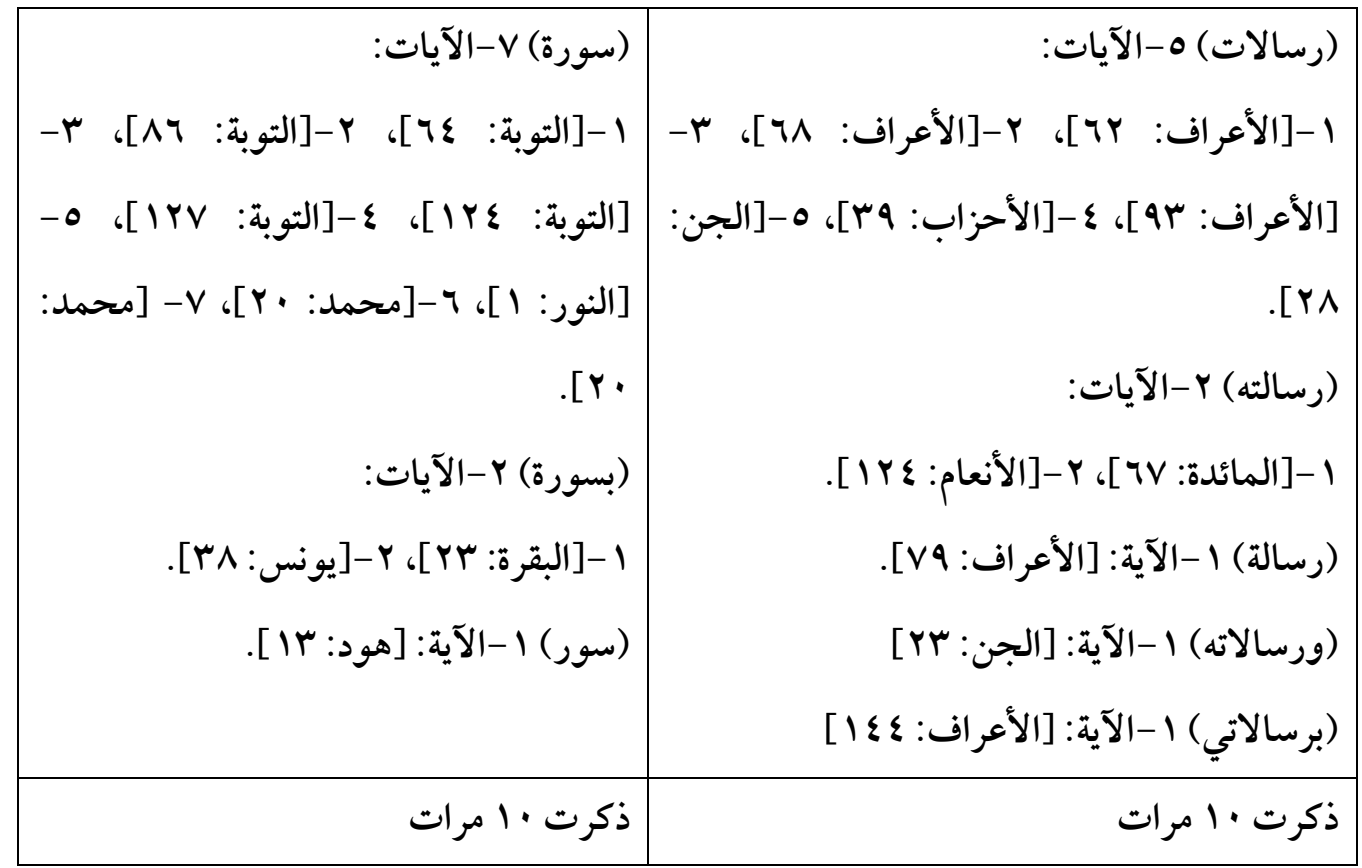

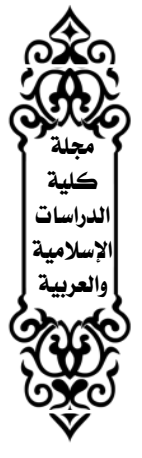

رابعا : محمد والسراج:

\begin{tabular}{|c|c|}
\hline 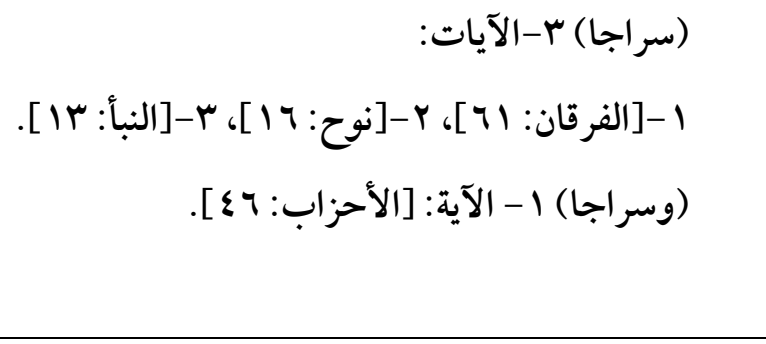 & 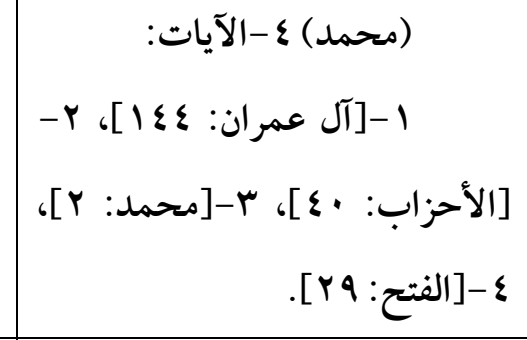 \\
\hline 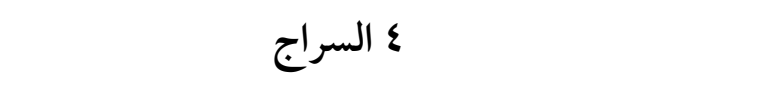 & 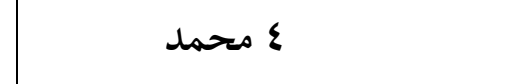 \\
\hline & خامسا : الملكوت وروح القدس : \\
\hline (روح القدس) ا-الآية: [النحل: r •1]. & 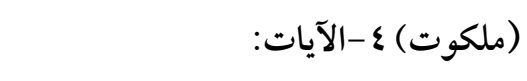 \\
\hline (بروح القدس) ب-الآيات: & 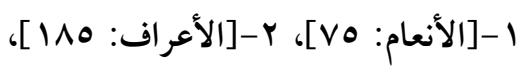 \\
\hline 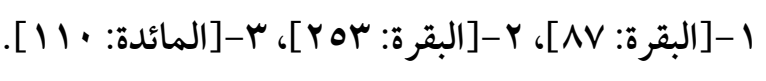 & 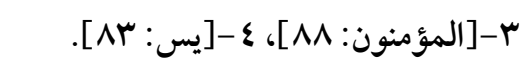 \\
\hline 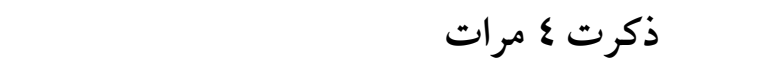 & ذكرت ع مرات \\
\hline
\end{tabular}


سادسا : الأسباط والحواريوز :

\begin{tabular}{|c|c|}
\hline (الحواريون) r- الآيات: & (والأسباط) ع -الآيات: \\
\hline 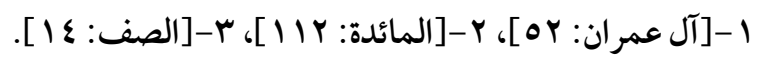 & 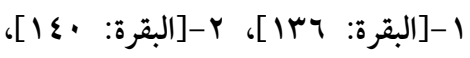 \\
\hline (الحواريين) 1 -الآية: [المائدة: 1111] & ץ-[آل عمران: ع^]، ع -[النساء: سד 1]. \\
\hline (للحواريين) ا -الآية: [الصف: ع 1]]. & (أسباطا) ا -الآية: [الأعر اف: • ج1 ]. \\
\hline 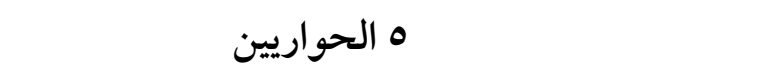 & ه الأسباط \\
\hline
\end{tabular}

وفيما يتعلق بالإيمان باليوم الآخر ترد مشتقات الجحيم لتوازي ما يرادفها من مشتقات كلمة

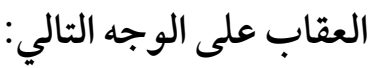

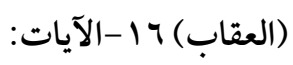

(الجحيم) (الجr-الآيات:

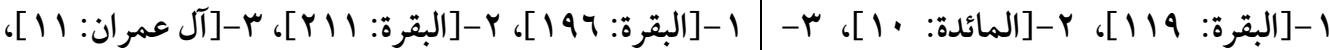

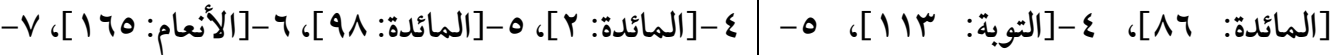

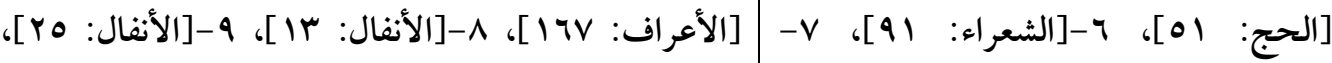

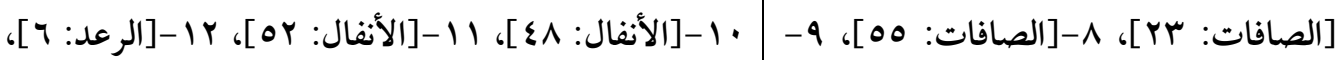

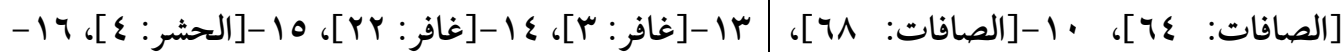

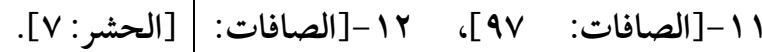

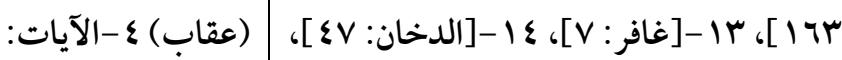

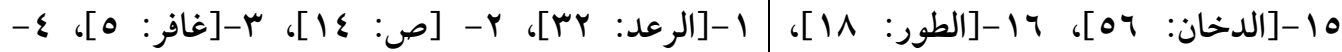
IV-1V

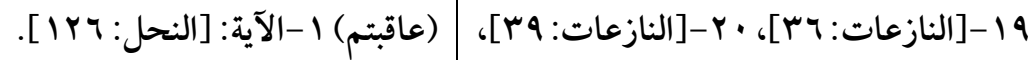

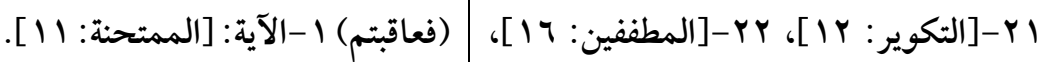

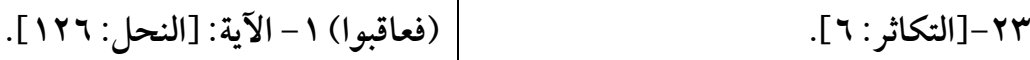

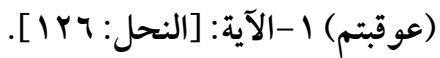

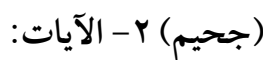

(عاقب) ا -الآية: [الحج: ·r].

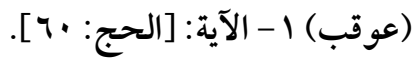

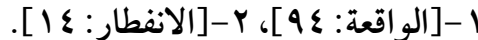

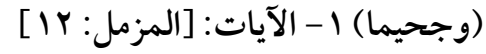
Tr العقاب ب الجحيم 
وفيما يختص بالمتعلق الثاني الخاص بالعبادات من صلاة وزكاة وصيام وحج فترد مشتقات كلمة الصلاة لتوازي ما يرادفها من مشتقات كلمة النجاة، وترد مشتقات كلمة الزكاة لتوازي ما ير ادفها من مشتقات كلمة البر كات، وترد مشتقات كلمة الصيام لتوازي ما ير ادفها من مشتقات كلمة الصبر، وهو ما يتجلَّى في الجداول التالية:

\begin{tabular}{|c|c|}
\hline 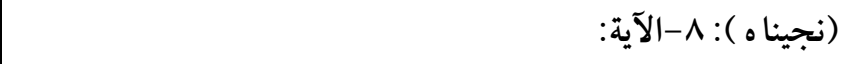 & 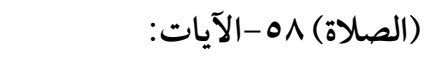 \\
\hline 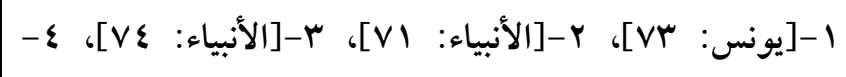 & 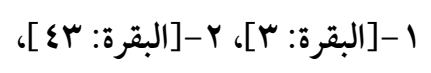 \\
\hline 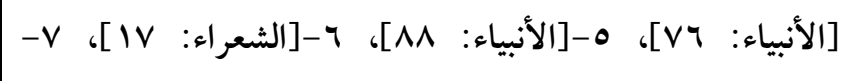 & r- \\
\hline 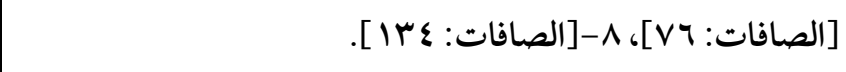 & . \\
\hline 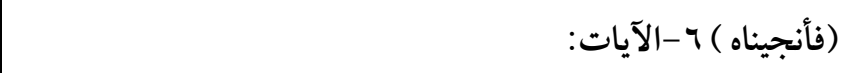 & [البقرة: rVV]، [النساء: \\
\hline 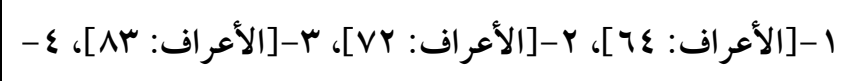 & 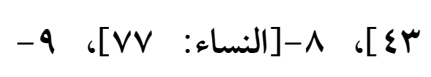 \\
\hline 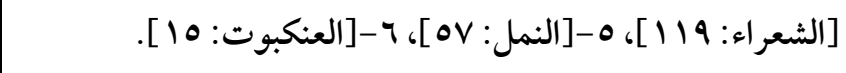 & [النساء: 1.1]، • •1-1النساء: \\
\hline (نجينا) ه-الآيات: & 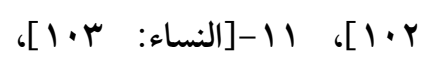 \\
\hline 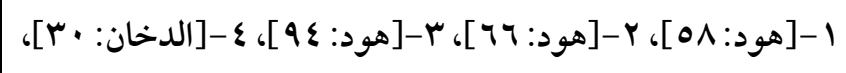 & r \\
\hline 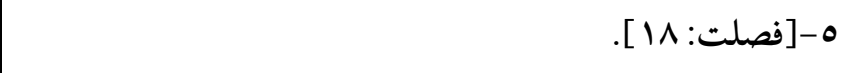 & 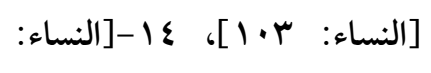 \\
\hline 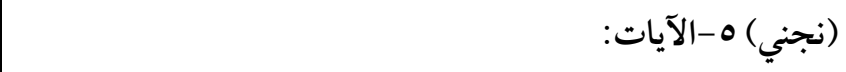 & r \\
\hline 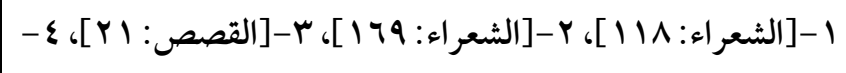 & T 1 - [المائدة: ج]، IV I [المائدة: \\
\hline [ التحريم: 11]، ه- [1التحريم: 11]. & צا \\
\hline 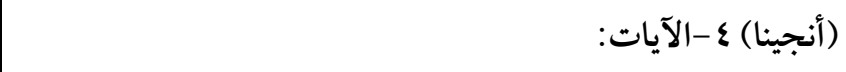 & [المائدة: ^ه]، •ץ-[المائدة: \\
\hline 1-[الأعراف: 170]، צ-[هود: 1711]، r-[الشعراء: 07 ]، ع- & 19]، 1/المائدة: \\
\hline [النمل: سor]. & 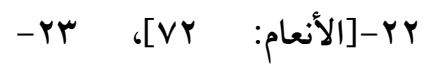 \\
\hline 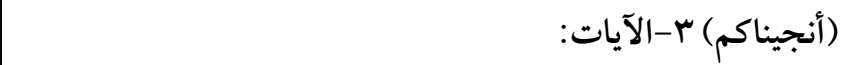 & 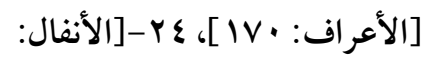 \\
\hline 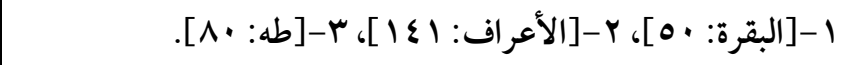 & 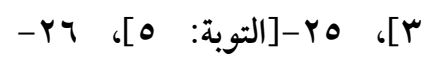 \\
\hline 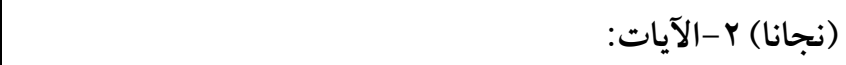 & 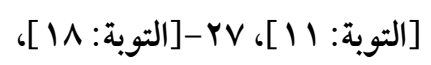 \\
\hline 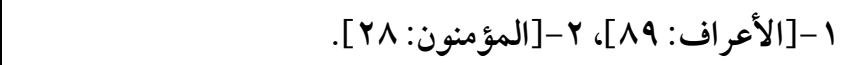 & 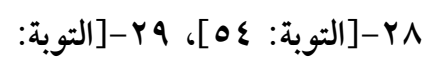 \\
\hline
\end{tabular}




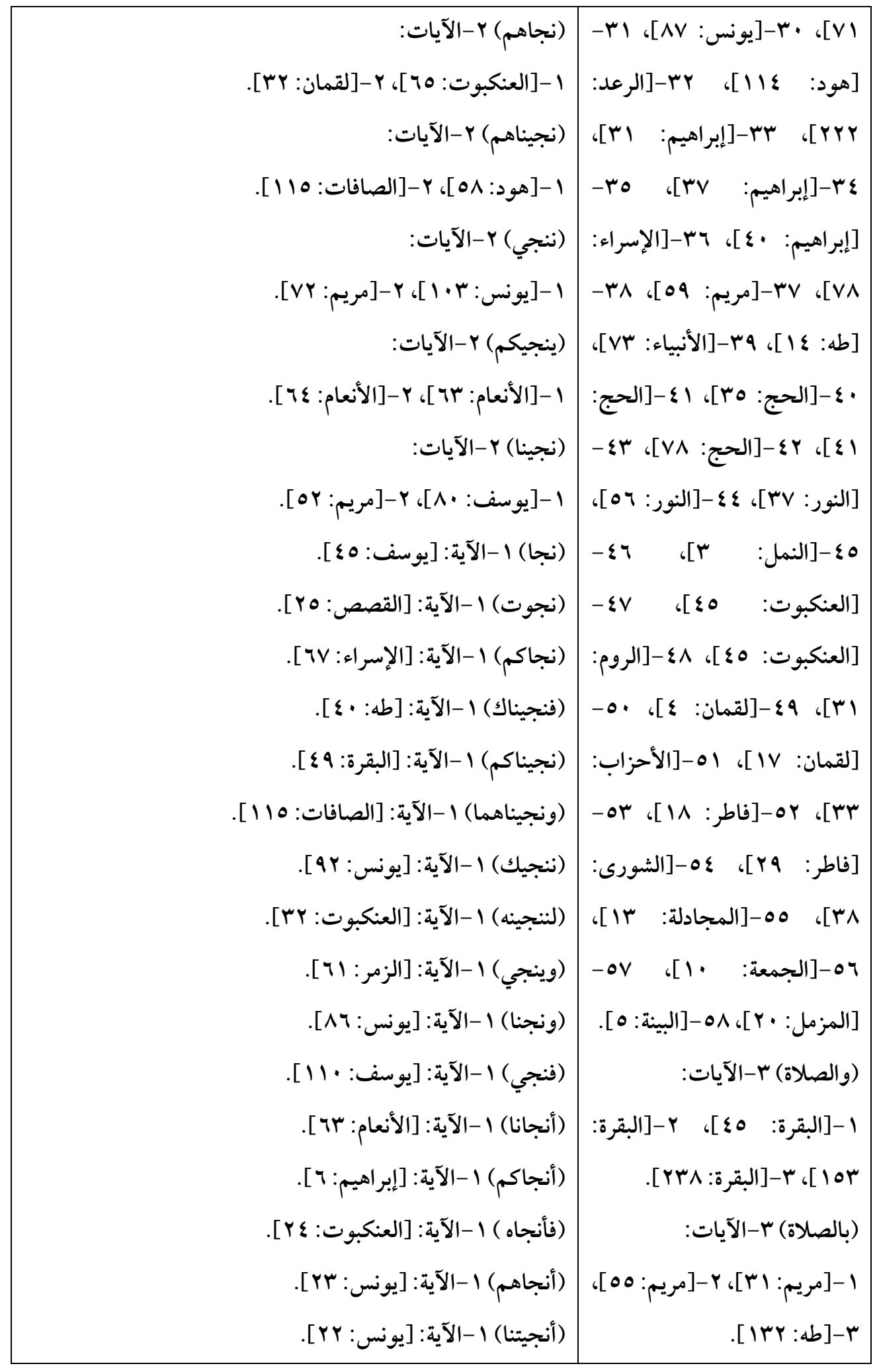




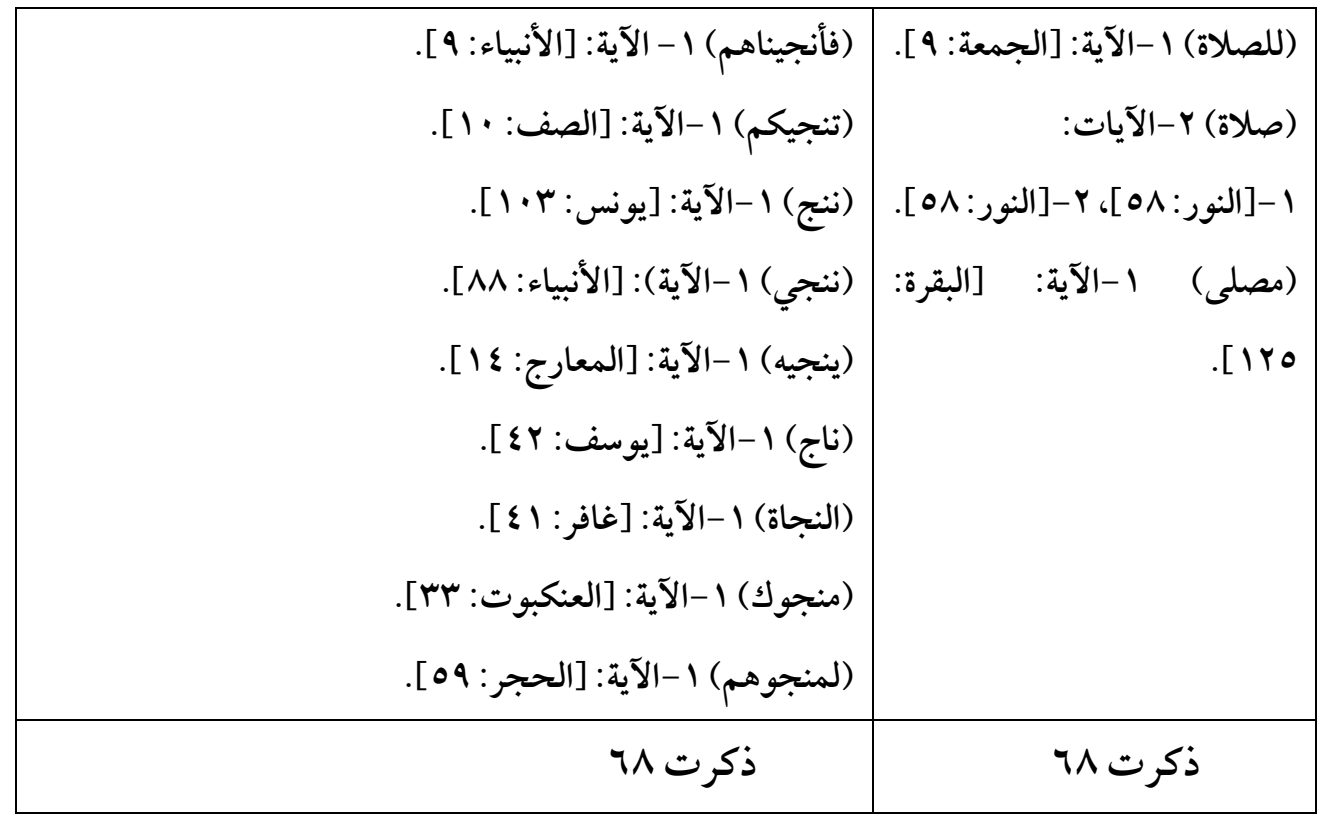

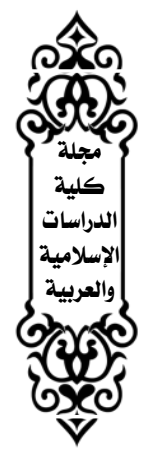

- ثنائية الزكاة والبركة :

\begin{tabular}{|c|c|}
\hline 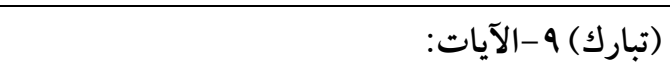 & آيات \\
\hline 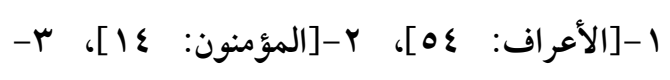 & 1-[البقرة: rع]، ץ-[البقرة: r^]، ץ-[البقرة: \\
\hline [الفرقان: 1]، ع-[الفرقان: · I]، ه-[الفرقان: آד]، & . \\
\hline 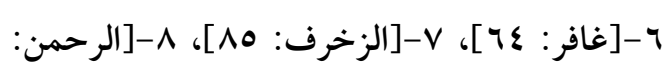 & 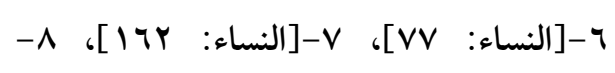 \\
\hline 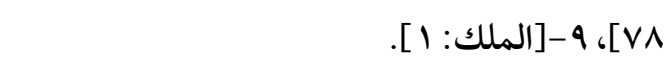 & [المائدة: \\
\hline 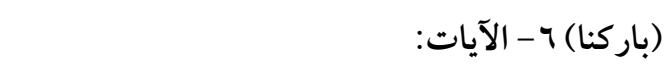 & [الأعراف: 107]، 1 1-[التوبة: 0]، r|- \\
\hline 1-[الأعراف: IrV]، ץ-[الإسراء: 1]، س-[الأنبياء & 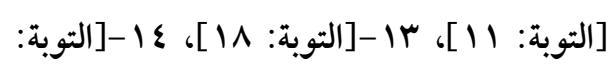 \\
\hline 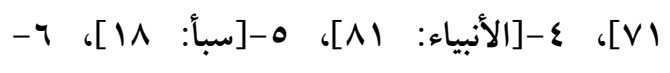 & \\
\hline 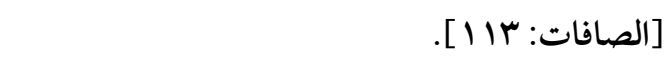 & 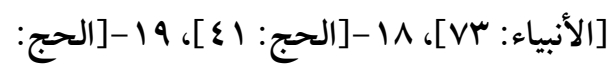 \\
\hline (مبارك) ع - الآيات: & 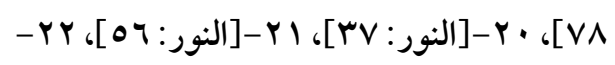 \\
\hline 1-[الأنعام: צ 4]، ץ-[الأنعام: 100]، ץ-[الأنبياء & 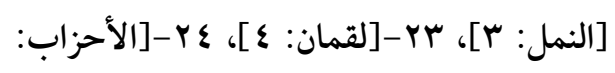 \\
\hline$[r$ & ] [فصلت: [V]، צץ-[المجادلة: rا]]، \\
\hline 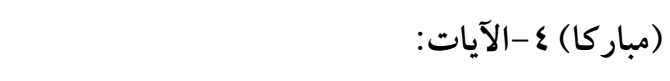 & 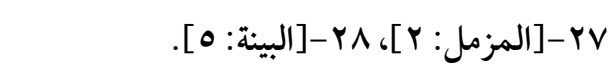 \\
\hline عمران: ج4]، צ-[مريم: ابس]، r-[المؤمنون & 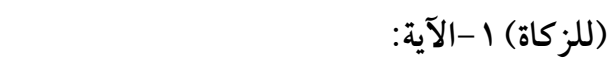 \\
\hline
\end{tabular}




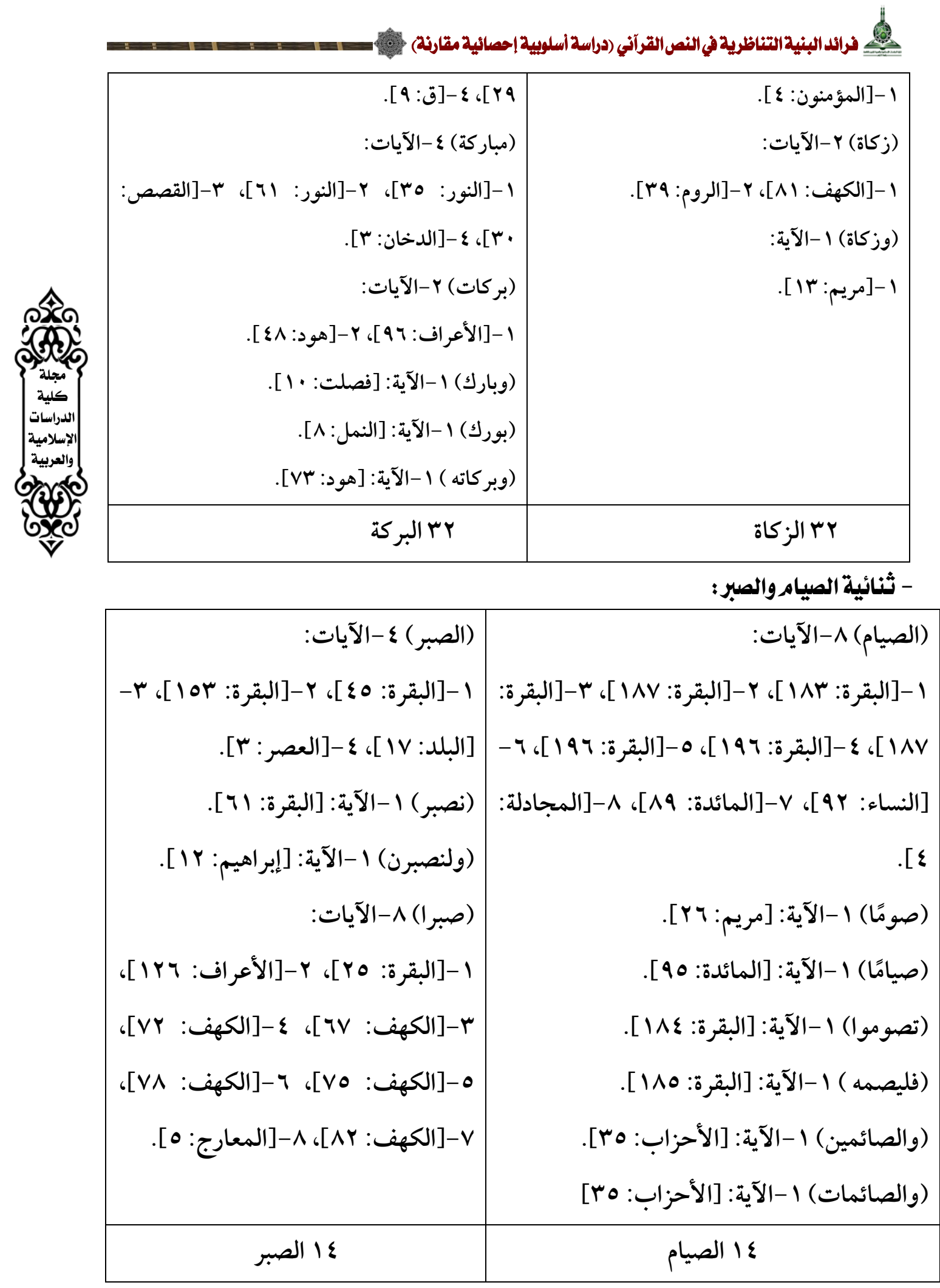


-

\begin{tabular}{|c|c|}
\hline (تطمئن) ا-الآية: [الرعد: Y^] & (الحج) 9- الآيات: \\
\hline (وتطمئن) ب-الآية: & 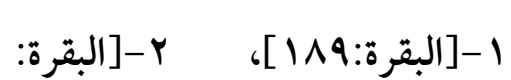 \\
\hline 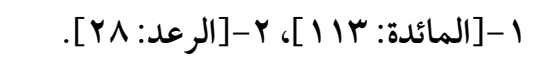 & 197]، r-[القة:197]، ع- \\
\hline (ولتطمئن) Y-الآية: & - \\
\hline 1-[آل عمران: צr 1]]، צ-[الأنفال: · 1]. & :197:، \\
\hline (مطمئنة) ا-الآية: [النحل: Y I ] ]. & 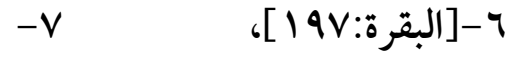 \\
\hline (المطمئنة) ا-الآية: [الفجر: FVV]. & [البقرة:19V1]، 1-[التوبة:ץ]، 9 - \\
\hline (اطمأن) |-الآية: [الحج: 11]. & {$[r v:$} \\
\hline (اطمأنتم) ا-الآية: [النساء: r •1]. & (جحج) ا - الآية: [آل عمران:9V] \\
\hline (واطمأنوا) ا-الآية: [يونس: ]V]. & (الحاج) | - الآية: [التوبة:919] \\
\hline (ليطمئن) ا-الآية: [البقرة: •rY]. & \\
\hline (مطمئن) ا-الآية: [النحل: ج.1]]. & 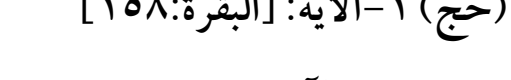 \\
\hline (مطمئين) ا-الآية: [الإسراء: 90]. & ج) ا -الآية: [القصص:rv] \\
\hline با الطمأنينة & 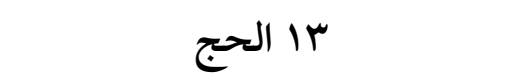 \\
\hline
\end{tabular}

وهكذا - و كما مرَّ - وإذا كان من أهم ثمرات المنهج الأسلوبي الإحصائي أنه يتيح إمكانية

التمييز بين أسلوب وآخر - من جانب - وتوثيق نسبة النص إلى صاحبه - من جانب آخر - ('). فإن هذه المتوازيات الإحصائية المتكررة في مجمل النص القر آني لَتؤكد - وفقا للحقيقة الرياضية التي لا تقبل النقض - تفرُّد هذا النص الإلهي عن غيره من النصوص التي كتبها البشر أو تَدََّّلَ البشر في تحريفها، كما تؤكد نسبة هذا النص المتفرد إلى الإله الواحد الأحد، وذلك لما تفصح عنه هذه الأنساق التكرارية المتوازية من استعصاء على قدرات البشر، حيث نزلت آيات الكتاب الكريم منجمة ومتفرقة على مدى ثلاثة وعشرين عاما، وتعلقت كل مجموعة من الآيات بزمان 


\section{فرائدالبنية التناظرية في النص القرآني (دراسة اسلوبية إحصائية مقارنة)}

ومكان محددين وحادثة بعينها، ولا يستقيم عقلا ومنطقا أن يجتمع المدَّعون لعد كلمات متفرقة في نص ما على مدى هذا الزمن الذي يتجاوز عقدين، وتأتي أميَّةُ النبي الكريم لتؤ كد هذه الحقيقة التي مؤداها أن من يقرأ لا يستطيع إنجاز هذا العد والحصر على مدى هذه الحوادث المتفرقة على هذا الزمن الطويل، فكيف تكون حال من ليس بقاري؟؟ ثم كيف - والحال هذه - ألا يفصح

من يقدم على تحقيق هذا الجهد المضني عما في النص من هذا البناء الإحصائي المحكم ليبقى سِرَّا مقدسا منذ وفاة النبي - صلى الله عليه وسلم - سنة (11 هـ ) إلى النصف الثاني من القرن الرابع عشر الهجري(') - (') ولا تفصح الأسرار المقدسة التي أشار إليها روبرت لوث فيما انطوى عليه النص التوراتي من معجزات البنيات الترادفية عن أية دلالات فيما يتعلَّق بتردد المعاني المتر ادفة في أية ثنائية من تلك الثنائيات التي تجلَّت فرائدها في كتاب الله الكريم، وهو ما يتجلَّى واضحا في الإحصاءات التالية لعدد من الثنائيات التوراتية الموازية للثنائيات التي مرَّ ذكرها فيما يتعلَّق بفر ائد التناظريات

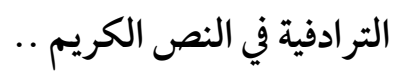

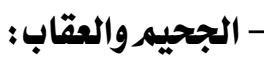

\begin{tabular}{|c|c|}
\hline 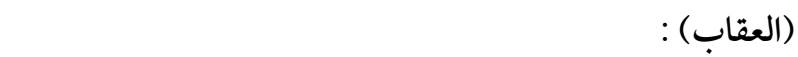 & (الجحيم) : \\
\hline 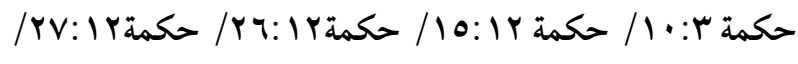 & 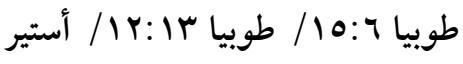 \\
\hline 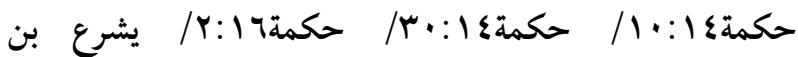 & 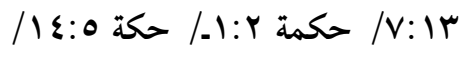 \\
\hline 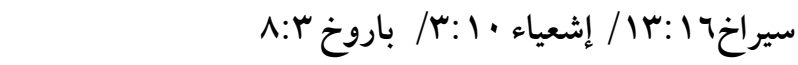 & 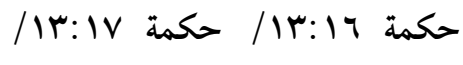 \\
\hline 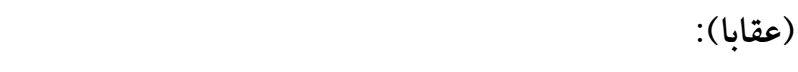 & يشرع بن سيراخ IV:9/ يشرع بن \\
\hline 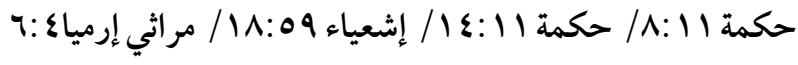 & |r / ا يشرع بن سيراخ \\
\hline
\end{tabular}

( ( ) حيث وردت الإشارات الأولى لهذه الأنماط المتوازية في كلمات النص القر آني في كتاب د. عبد الرزاق نوفل

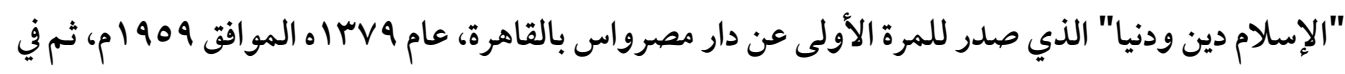

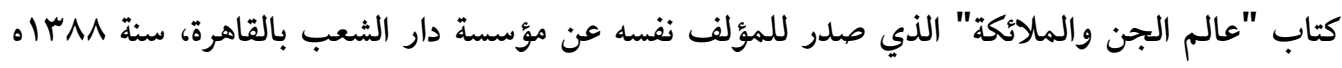

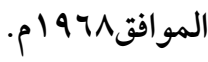


المجلد الثامن والثلاثون إصدار يونيو.r.r

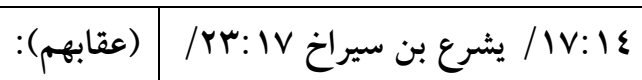

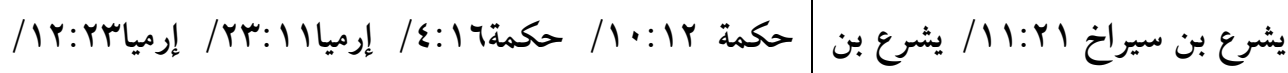

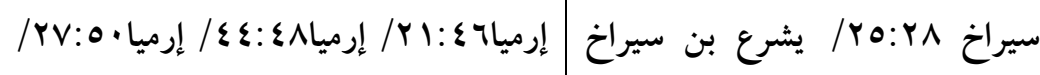

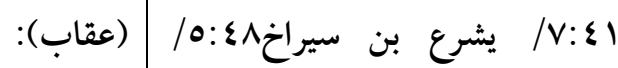

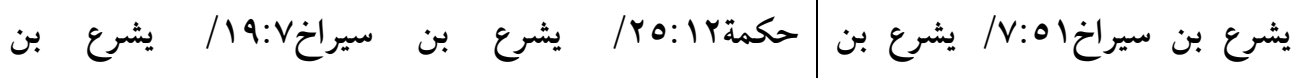

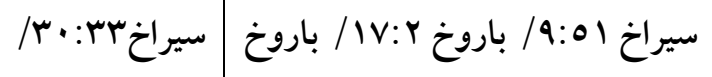

$$
\begin{aligned}
& \text { r:r }
\end{aligned}
$$

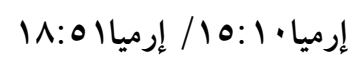

(للجحيم):

(عقابي):

حكمة 1:1 1

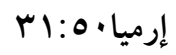

\begin{tabular}{|c|c|}
\hline 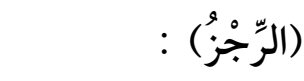 & 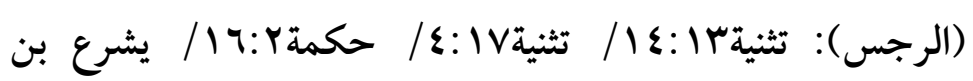 \\
\hline أيوبr:؟r & | \\
\hline 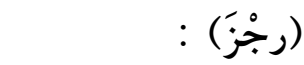 & 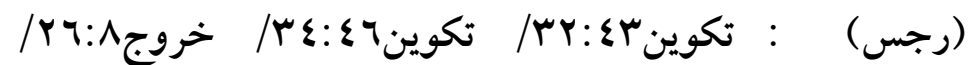 \\
\hline 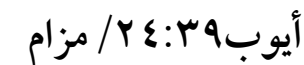 & 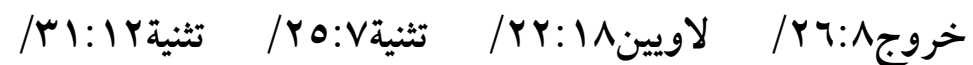 \\
\hline 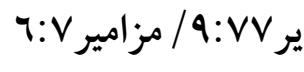 & 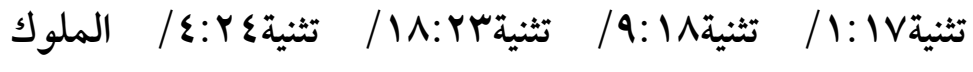 \\
\hline 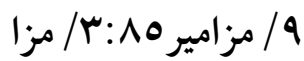 & 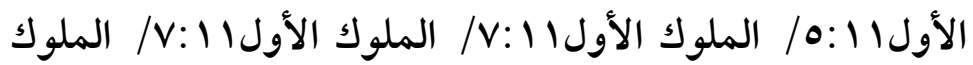 \\
\hline 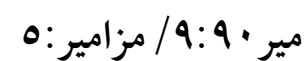 & 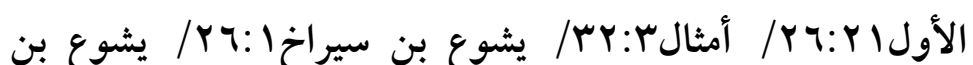 \\
\hline 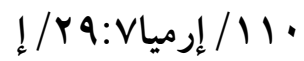 & بشوع بن سيراخr| : Y / يشو \\
\hline ro:० & 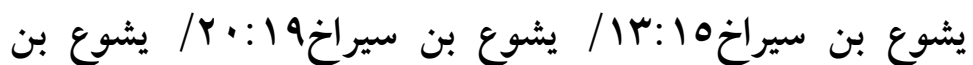 \\
\hline 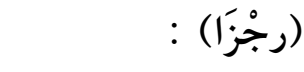 & 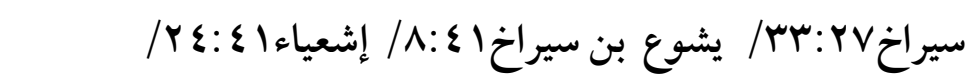 \\
\hline 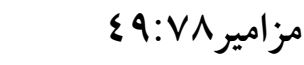 & 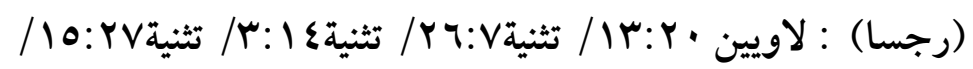 \\
\hline & 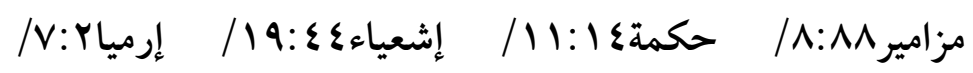 \\
\hline
\end{tabular}

- الرجس والرجز : - الر - 


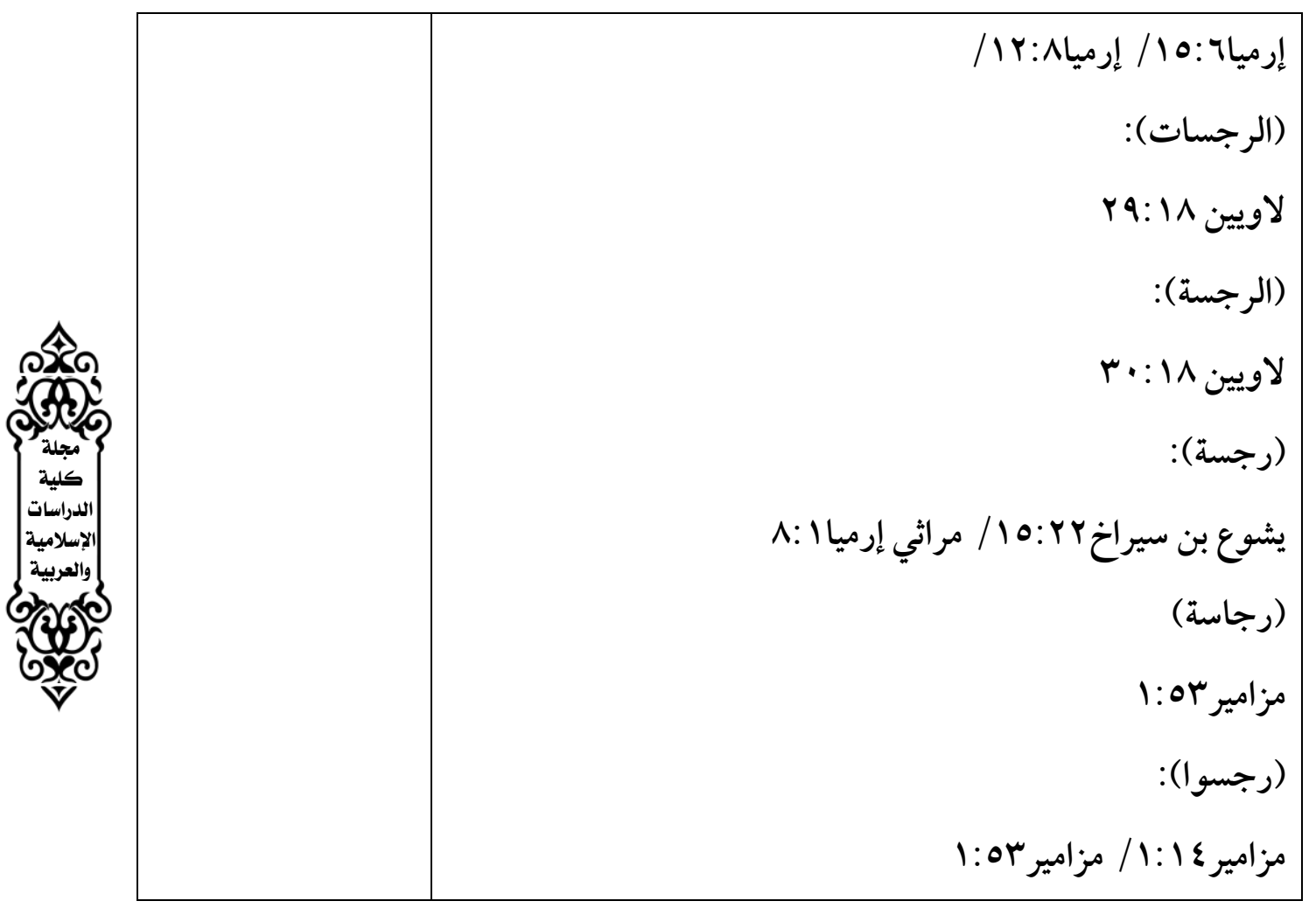

- الطهر والإخلاص: - الم

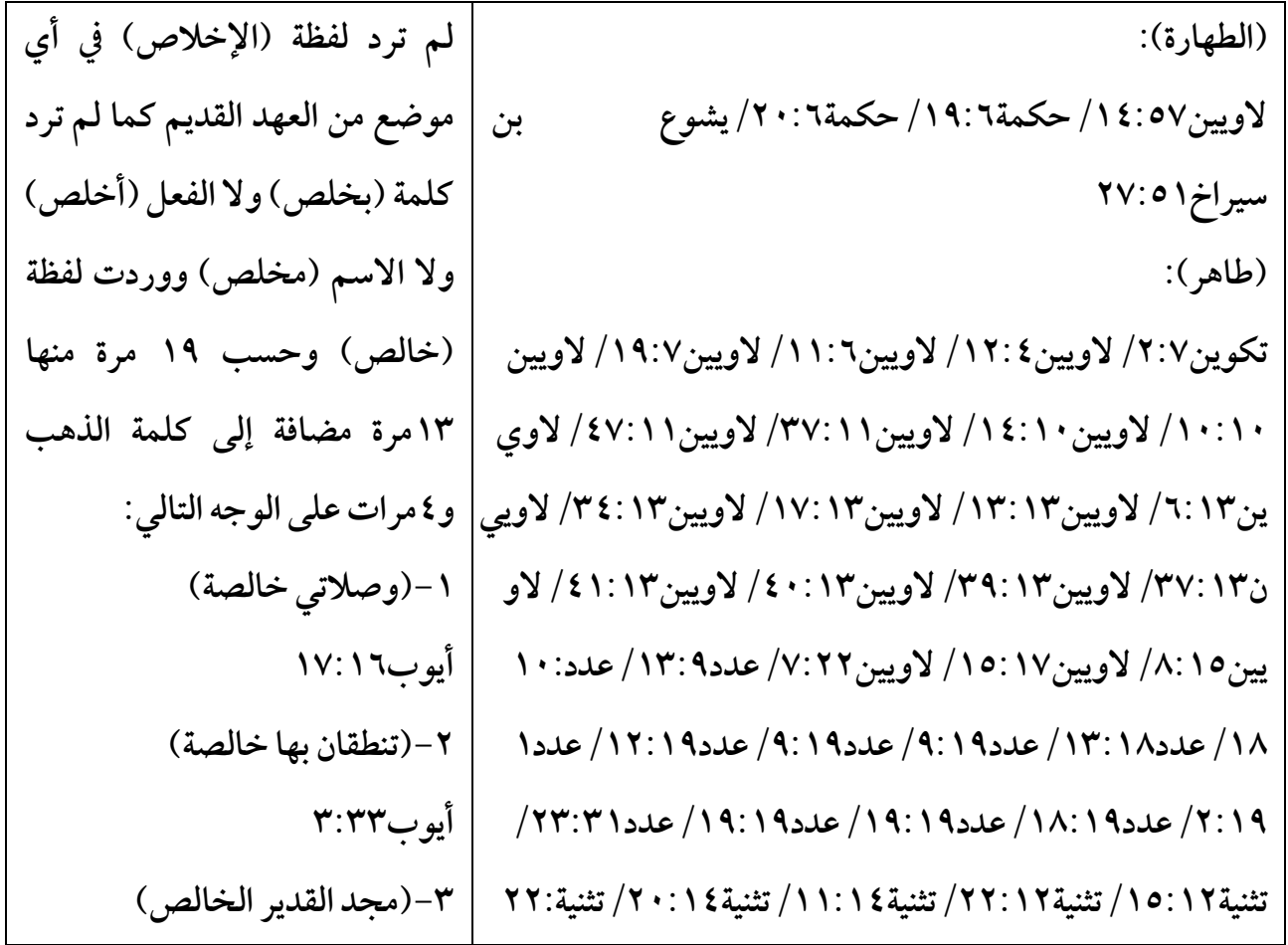




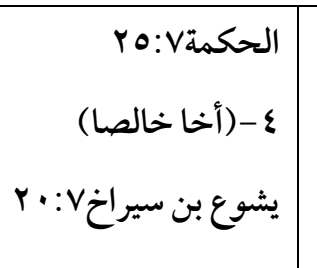

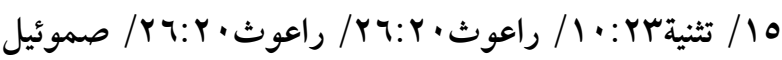

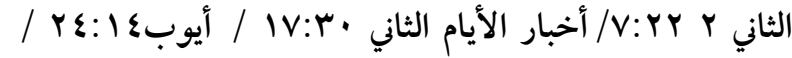

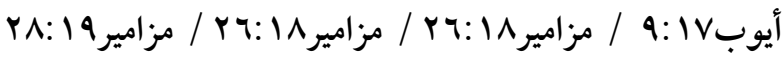

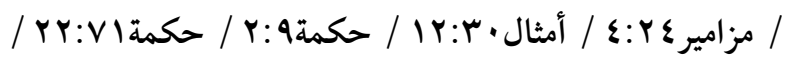

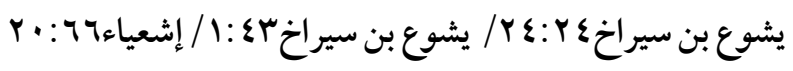

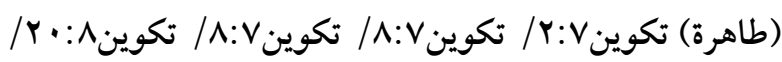

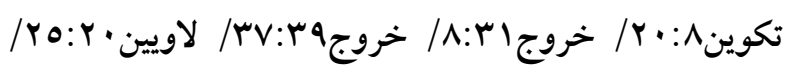

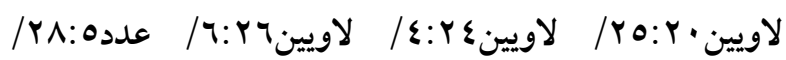

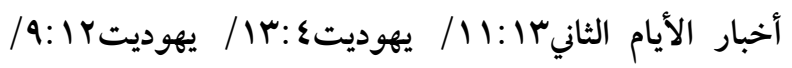

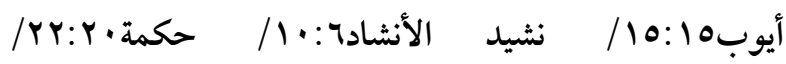

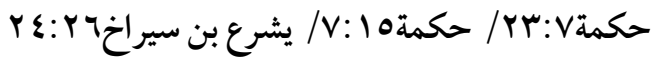

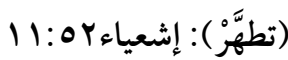

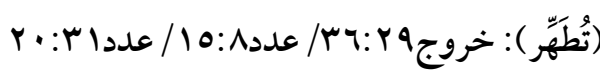

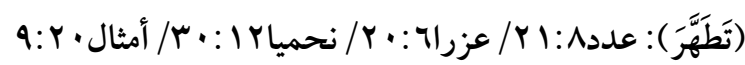

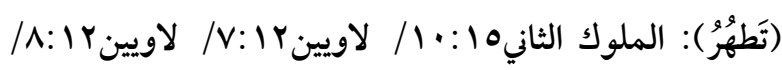

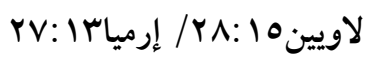

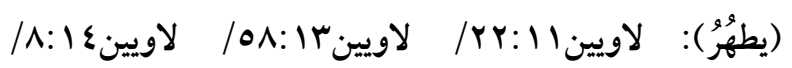

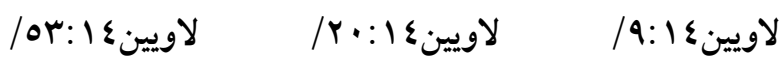

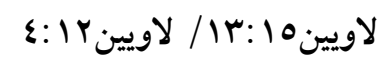

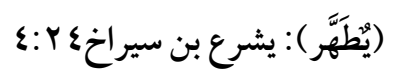

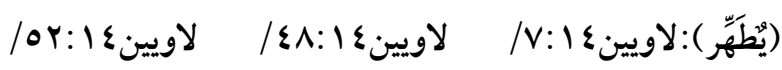

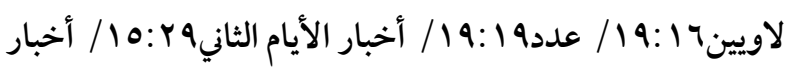

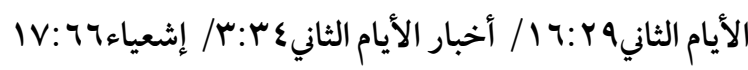

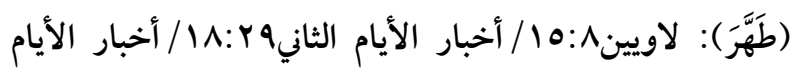

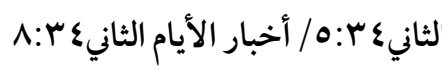
V: 


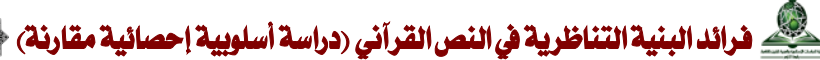

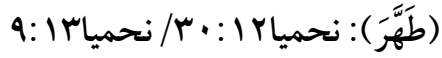

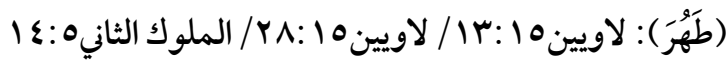

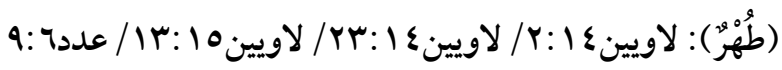
(أَطْهُرَ) ): الملوك الثانيهـ

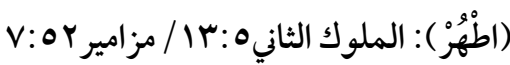

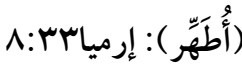

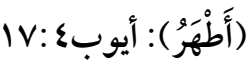

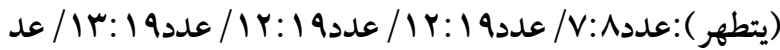

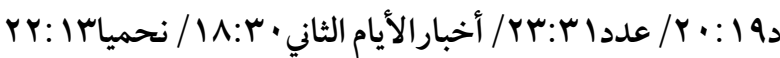
IV:Yr (نتطهر ): يشرع

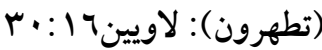
(مطهرة): صموئيل الثاني| 1 : (المطهر ): لاويينع 11:

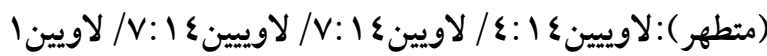

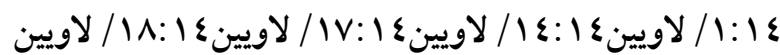

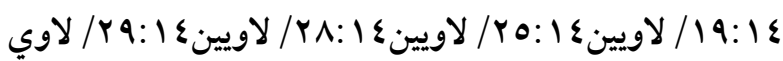
بين إ: (طاهران): لاويين 1 :

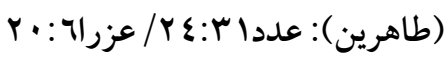
(طاهرتين): لاويين | 1 :جr

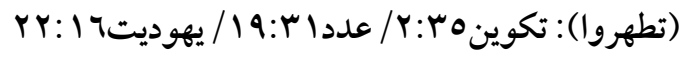




\section{المبحث الثالث}

\section{التناظرية التركيبية}

- التوازي التركيبي في النص التوراتي من خلال دراسات "روبرت لوث”؛

syntactic "فصَّل “روبرت لوث" مفهوم "الازدواج أو التوازي التركيبي أو البنائي

or constructive pairs تقارب البنية التركيبية للجمل بعضها من بعض، وهو في هذا يختلف عن النوعين السابقين اللذين يتحققان في التكرار أو المعارضة، حيث يتحدد - وحسب - من خلال التوازي في شكل من أشكال البناء"( ()، واستثهد على مضمونه بهذه العبارات من سِفر المزامير: 1 - نَامُوسُ الرَّبِّ كَامِلْ يُرُدُّ النََّْْس.

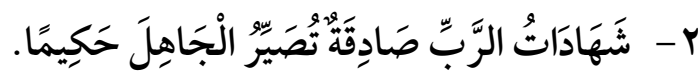

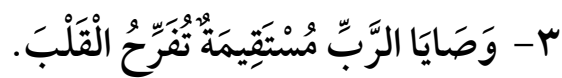
ع - أَمْرُ الرَّبِّ طَاهِرْ يُنيُرُ الْعَيْنَيْن.

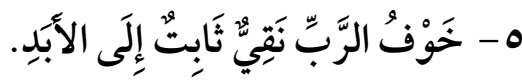

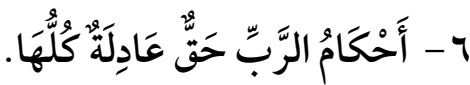

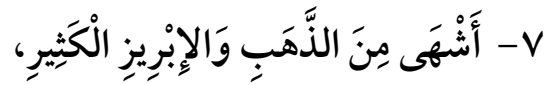

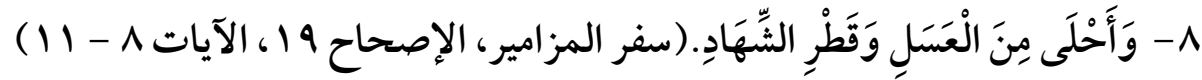
حيث تنبني العباراتُ الستُّ الأولى على بنية تركيبية واحدة متوازية، وتثترك جميعها فئي:

$$
\begin{aligned}
& \text { - } \\
& \text { - } \\
& \text { - ثالثا: الخبر الأول مفرد نكرة. }
\end{aligned}
$$

- رابعًا: يلي الخبر في الجمل الأربع الأولى جملة فعلية، وفي الجملتين الأخيرتين (رقم ه و

(1) Robert Lowth،Lecture on the sacred poetry of Hebrews ‘p162 
وتنبني العبارتان الأخيرتان (رقم لو م) على المشتر كات البنائية التالية: - أولاً الجملة الأولى تبدأ بخبر والجملة الثانية تبدأ بخبر معطوف. - ثانيا : كلتاهما تبدأ بأفعل التفضيل. - ثالثاً : في كلتا العبارتين بعد أفعل التفضيل شبه جملة (جارٌ ومجرور ). - رابعاً: كلتا الجملتين تنتهي بعطف. وقد ذكر “روبرت لوث” أن التوازي التركيبي يمتزج في كثير من الأحيان مع التوازي الترادفي والتوازي التقابلي (')، فمن شواهد الحال الأولى ما ورد في سفر المزامير:

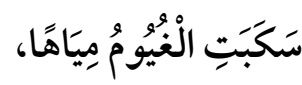

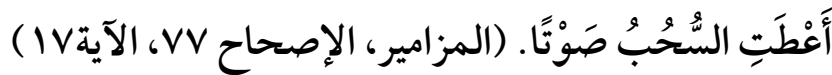
حيث ينطوي التوازي التركيبي على توازٍ ترادفِي واضٍِ، ومن شواهد الحال الثانية من سفر

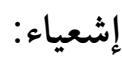
إِذَاً اجْتَزْتَ فِي الْمِيَاهِ فَأَنَا مَعَكَ،

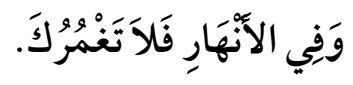
إِذَا مَشَيْتَ فِي النَّارِ فَلاَتُلْنَعُعُ

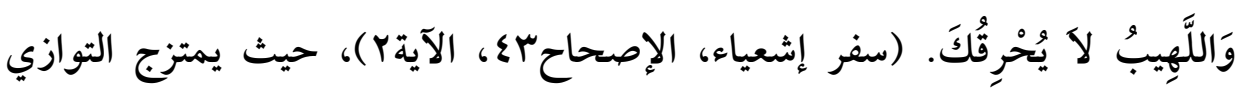

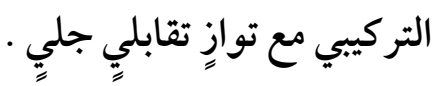
ويذكر روبرت لوث أن هـناك علاقةً جليةً بين التوازي التركيبي - من جانب - والإيقاع العروضي العبري - من جانب آخر -، فيقول: "وقد وضعت يدي على جزء كبير من الوزن العِبري في هذا النوع من التوازي التركيبي ... وبما أن الآثار الإيقاعية للفن الموزون تتشابه مع ما ورد في أسفار الأنبياء والأسفار الشعرية، فإنني أعتقد أن هـناك سببا كافيا لوضعها في نفس (1) Robert Lowth ،Lecture on the sacred poetry of Hebrews, p222 


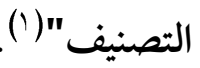

ويقصد "لوث" بهذا الربط أن الكلمات المتوازية تر كيبيا دائما ما تحمل توازيا إيقاعيا مناظرا، كما هو الثأن في عددٍ من الكلمات المتوازية وزنا في الشاهد المذكور من سفر المزامير، مثل "أمر الرب" و"خوف الرب"(r).

\section{- التوازي التركيبي بين روبرت لوث والدراسات القرآنية :}

وقد أشارت الدراسات القر آنية من خلال منهجيتها الوصفية إلى هذه التناظرية التركيبية التي تطرَّرد في عبارات القرآن الكريم في عددٍ هائل من الآيات، وخصوصا في العُشْرِ الأخيرِ من

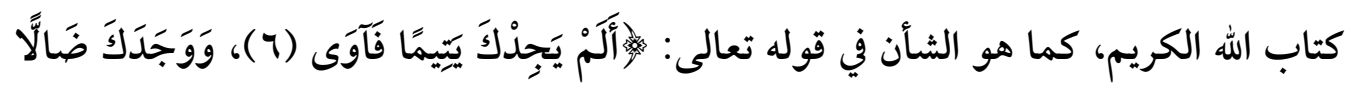

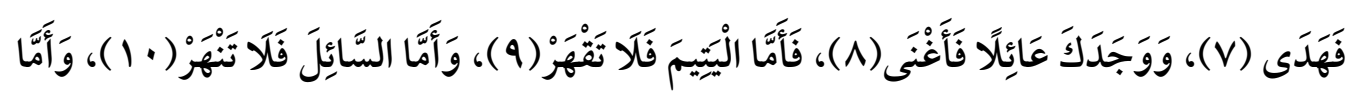

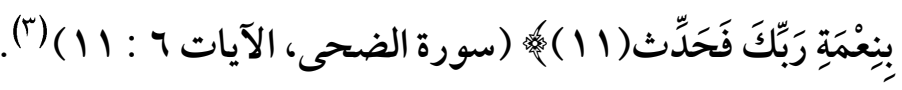

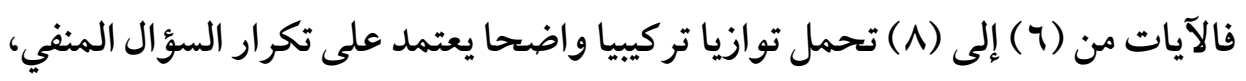
في حين تحمل الآيات من (9) إلى (11) توازيا مقابلا بين البدء بالخبر والانتهاء بالإنشاء.. وفي حين لم تطرح شواهد "روبرت لوث" أية علاقة معنوية يمكن أن تقدم تعليلا للعبارات المتوازية تركيبيا من شأنه أن ينقلها من إطار التشابه التركيبي الشكلي المجرد إلى لى رحاب التشابه التركيبي المعلل فكريا، نجد هذه العبارات القر آنية تتعالق وفق ترتيب مخصوص لا يقصر التوازي التركيبي على إطار التشابه الشكلي، بل يتسع به إلى آفاق التشابه المعلَّل معنويا

\section{(1) Ibid, p224}

(r) ويشير لوث إلى أن هذا التوازي الإيقاعي العروضي يرتبط باللغة العبرية ولا يمكن ترجمته في العبارات

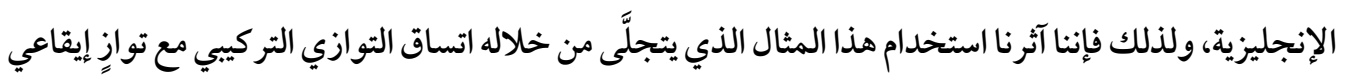

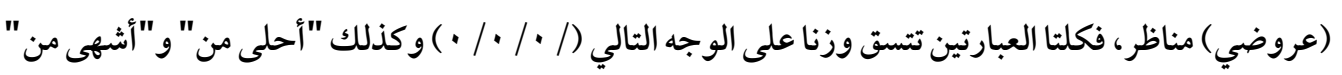
حيث تتسق العبارتان أيضا في الصورة الإيقاعية (/ • • / • • )...

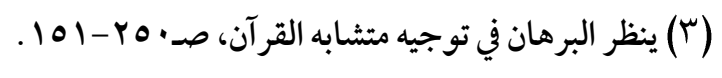




\section{: فرائد البنية التناظرية في النص القرآني (دراسة اسلوبية احصائية مقارنة)}

والمدعَّم فكريا، حيث يتعلَّق ترتيب الآيات الثلاث الأخيرة بترتيب الآيات الثلاث الأولى، إذ

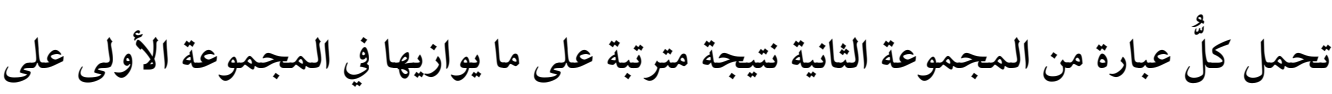

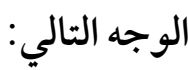

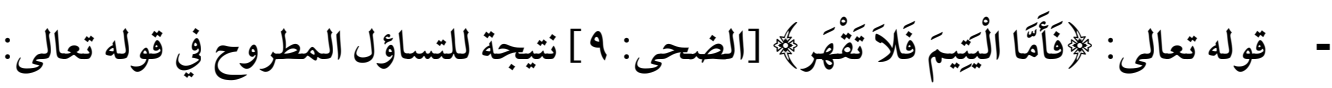

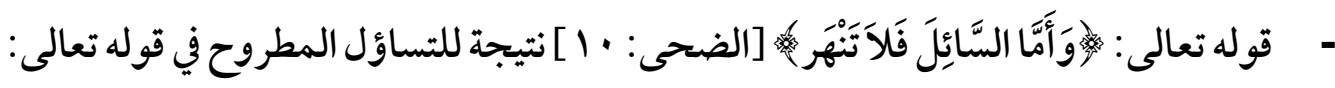

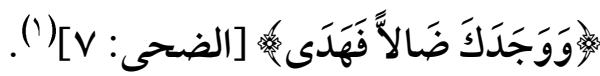

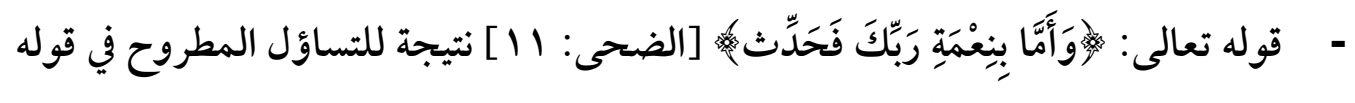

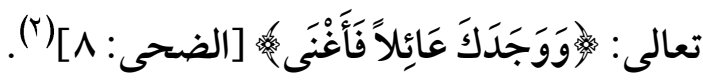

وهنالك ملاحظة أخرى شديدة الأهمية تجلي الفارق بين دراسات روبرت لوث والدراسات القر آنية لأنماط التوازي التركيب، حيث يقف روبرت لوث على مظاهر التكرار في التوازي التركيبي في النص التوراتي دون أن يتجاوزها إلى ما تنطوي عليه شواهدها من مظاهر كسر هذا التكرار، في حين تتجاوز الدراسات القرآنية في تناولها مظاهر التوازي التركيبي ملامح التكرار لتقف على مظاهر التنوع في التراكيب المتوازية وهو ما يمكن أن يطلق عليه (البحث عن

ملامح التنوع في إطار النغمة الواحدة) أو (البحث عن ملامح العدول عن التوازي التركيبي)

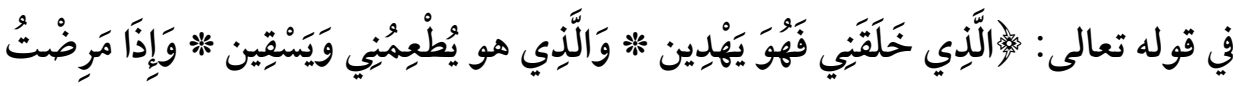

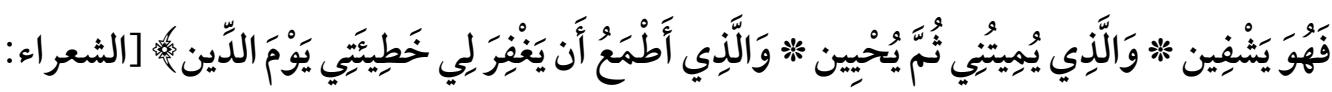

( (1) لأن معنى السؤال يشمل المفهوم المعنوي (سؤال الهداية كما هو الشأن في قصة عبد الله ابن أم مكتوم)

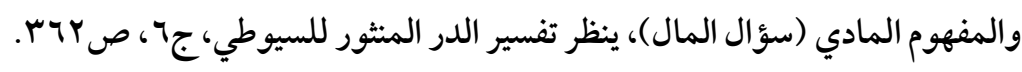
(Y) ينظر في تفصيل ذلك الكرماني (يحي بن حمزة)، البرهان في توجيه متشابه القرآن لما فيه من الحجة والبيان،

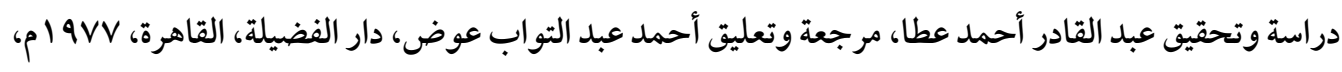




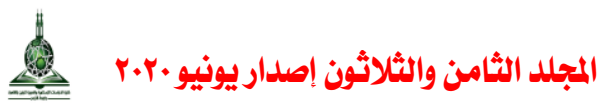

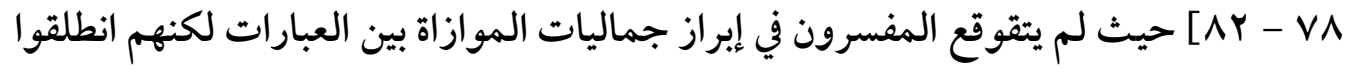

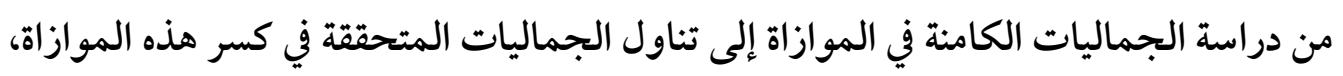

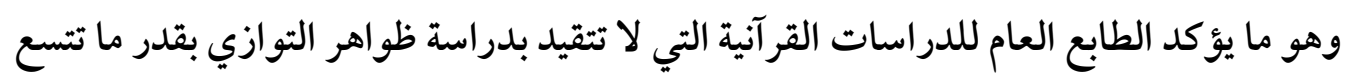

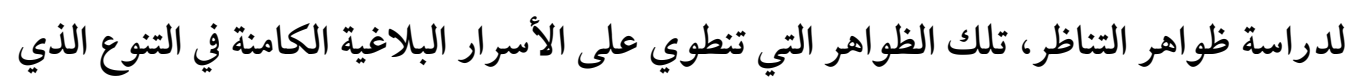

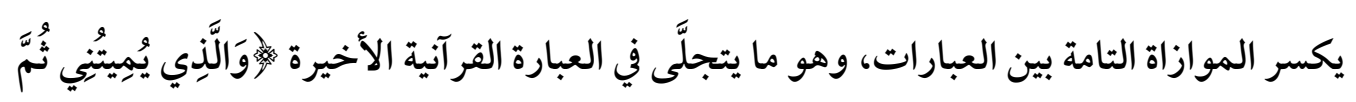

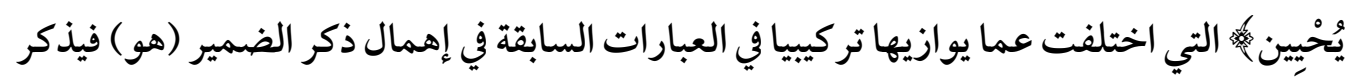

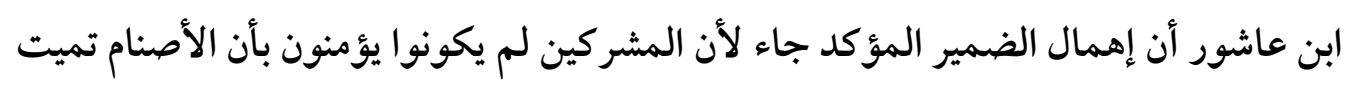

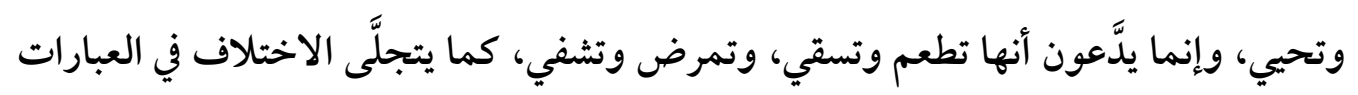

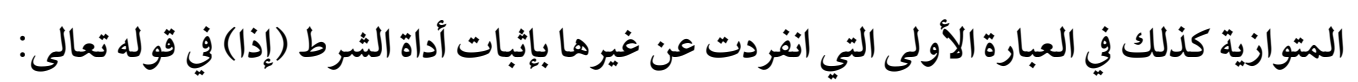

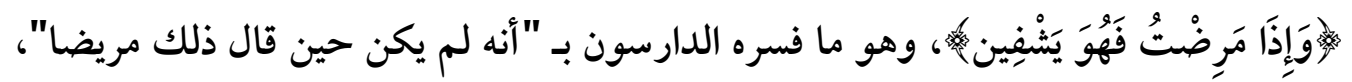

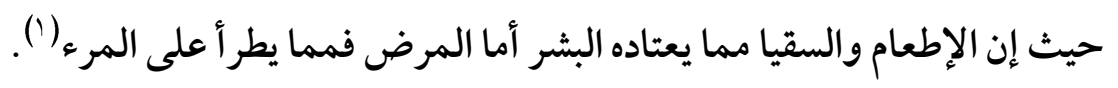

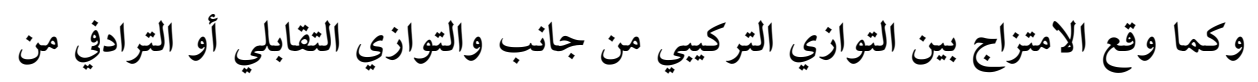

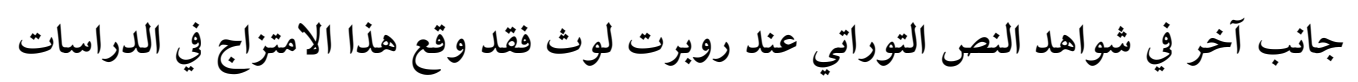

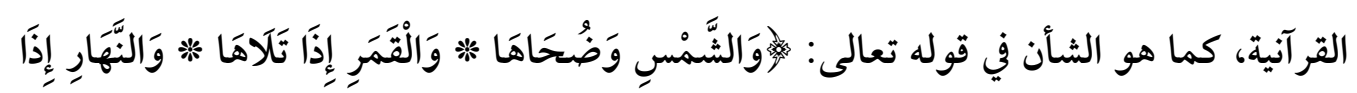

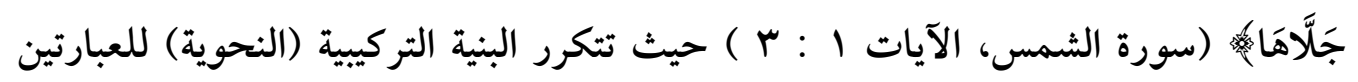

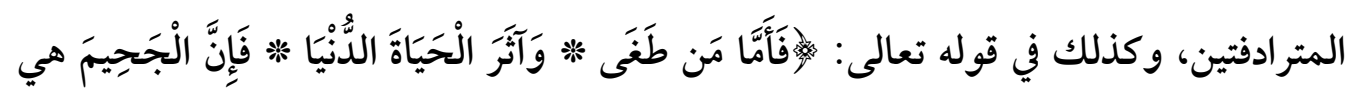

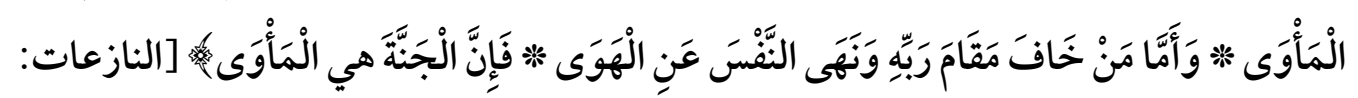

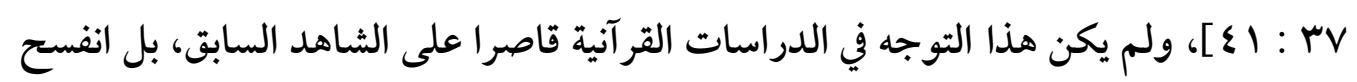

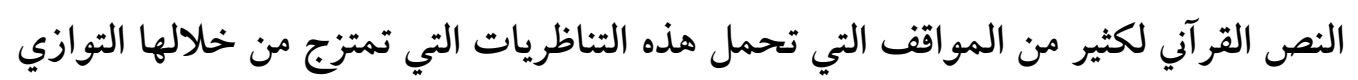

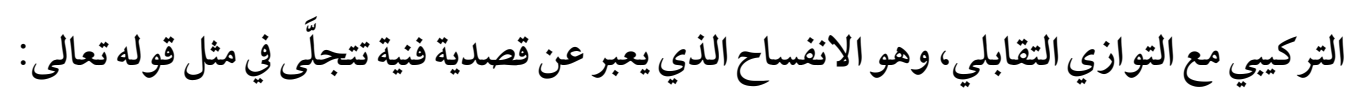

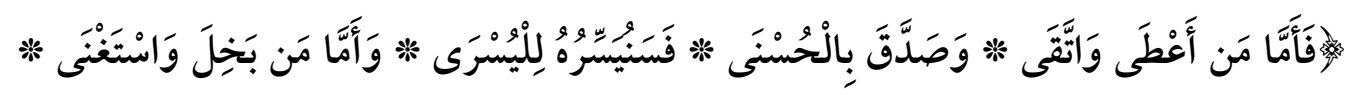




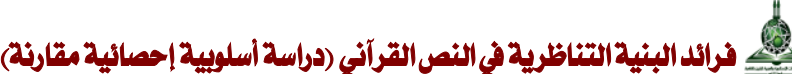

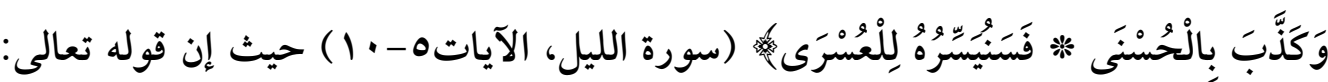

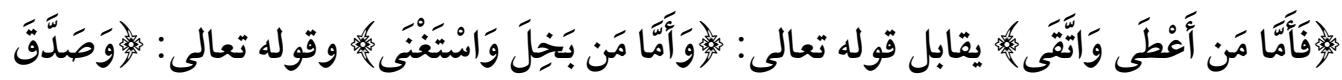

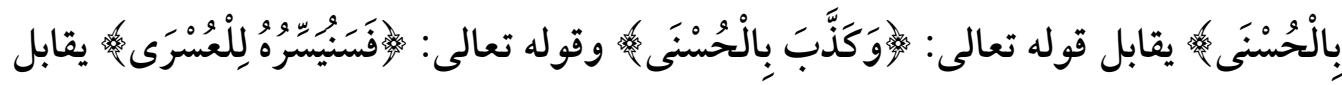

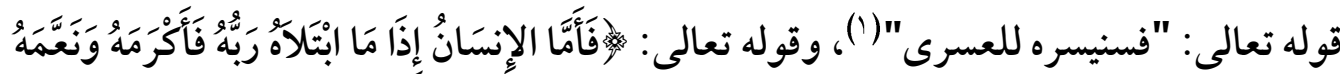

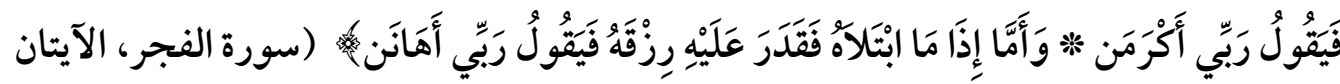

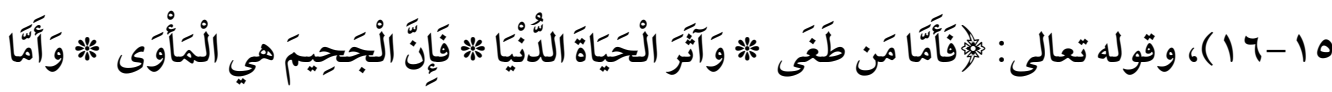

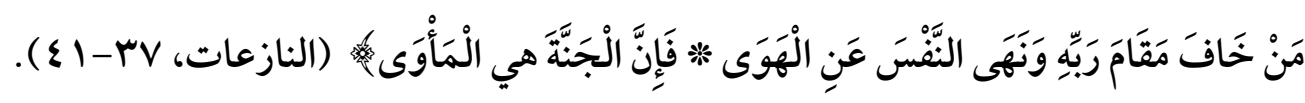
وكما وقع الامتزاج بين التوازي التركيبي والتوازي الإيقاعي في كثير من شواهد النص التوراتي فتد وقع ذلك الامتزاج في كثير من آيات الكتاب الكريم التي احتملت توازيا تركيبيا، كما هو الشأن في العبارتين "فَلَا تَقْهَهر" و"فَلَا تَنْهَه"، فكلتا العبارتين تتسقان من حيث توالي الحر كات والسكنات وفق الترتيب الإيقاعي التالي: (/ / / / . . ومن العبارات القليلة التي ساقها روبرت لوث بوصفها شواهد على الامتزاج بين التوازي

$$
\begin{aligned}
& \text { التركيبي والتوازي الإيقاعي هـاتان العبارتان من سفر التثنية: } \\
& \text { يَهْطِلْ كَالْمَطَرِ تَعْلِيمِي، }
\end{aligned}
$$

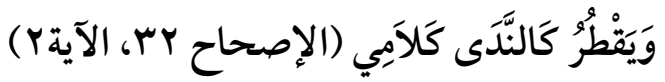

ويذكر لوث تعليقا على هـاتين العبارتين المتوازيتين تركيبيا أنهما تنطويان كذلك - وفق نطقهما في اللغة العِبرية - على تركيب عروضي "سداسي التفاعيل"((r)، ويكتفي لوث برصد الظاهرة ولا يقدم أيَّ تعليلٍ لها ل... وفي حين اكتفى روبرت لوث بعدد يسير من شواهد الإيقاع المتوازي في العهد القديم اتسع

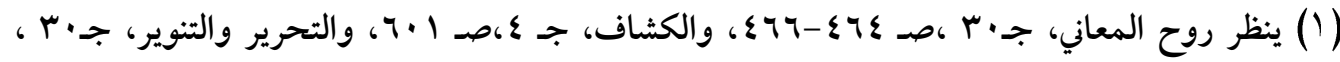

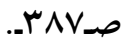

(2) Robert Lowth ،Lecture on the sacred poetry of Hebrews ‘p102 


\section{المجلد الثامن والثلاثون إصدار يونيو.r.r.}

الدرس العربي بمظاهر التناظر الإيقاعي في القرآن الكريم اتساعا كبيرا، وتجسَّدت إحدى أهم

ثمرات هذا الاهتمام في ظهور علم مستقل من علوم القرآن هو علم الفاصلة ('). وهنالك فارق آخر شديد الأهمية بين تناول التناظر الإيقاعي التوراتي عند لوث وما يقابله

عند دارسي النص القرآني، حيث كان الربط الذي أقامه روبرت لوث بين إيقاع العبارات وبنيتها التركيبية يقابله اتجاه مضاد في الدراسات القر آنية يحرّر البنيات التركيبية من الارتباط بالإيقاع، و كان لهذا الفارق نتيجةٌ مهمةٌ في آليات صياغة السياق الدلالي للنص التوراتي والنص القر آني، ذلك لأن هذا الربط من جانب روبرت لوث يعني أن الإيقاع النغمي في التوراة كان يسوق المعنى المؤسس على البنية التركيبية ويحدد اتجاهاته، وخصوصا أن روبرت لوث لم يقدم أيَّ تعليلٍ للبنيات التركيبية في النص التوراتي إلا التعليل النغمي .. وفي حين كان الإيقاع التنغيمي في النص التوراتي - بمقتضى منظور روبرت لوث - يعتمد على البنيات التركيبية للعبارات، كان الإيقاع التنغيمي في النص القرآني - بمقتضى منظور الدارسين العرب - مستقلا عن البنيات التركيبية، وفي حين كانت المفاهيم اللغوية المترتبة على البنيات التركيبية للعبارة التوراتية تتحدد بناء على المحتوى النغمي لهذه العبارات، كانت هذه المفاهيم في العبارات القر آنية لا ترتبط بمحتواها النغمي .. وآية ذلك الباب الكبير الذي شمله علم الفاصلة القر آنية، وعُنيَ فيه بقضية العدول عن الأصل في مقطع الفاصلة، حيث طرح النص القرآني تأويلات معنوية لكل تجليات التناظر الإيقاعي في الفواصل تتجاوز القيمة الشكلية المجردة المكتفية بالجرس الصوتي، واشتغل دارسو النص القر آني على فواصل الآي، وتتبعوا ما تنطوي عليه كل فاصلة من قيم تعبيرية ومعنوية مما يضيق المقام بعرضه، ولكننا سنعرض شاهدا واحدا ليعبر عن مناهج الدارسين في تناول هذه الظاهرة، وهو التناظر الإيقاعي في فواصل سورة الرحمن التي تتخذ إيقاعيا صورة ( / / ) وتنتهي صوتيا بالألف والنون، حيث أشار عدد قليل من الدارسين إلى أن البنية التركيبية المتمثلة في تثنية كلمة الجنتين في قوله تعالى: ولوَلِمَنْ خَافَ

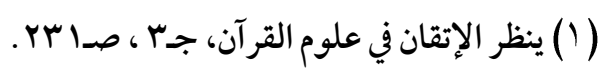




\section{مرائل البنية التناظرية في النص القرآني (دراسة اسلوبية إحصائية مقارنة)}

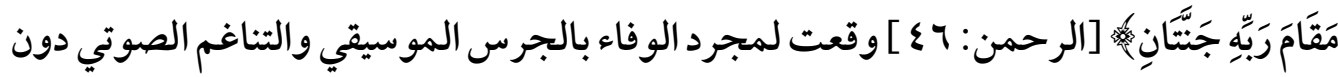
النظر لأية قيمة معنوية ....... (')، وهو الأمر الذي حفز الدارسين قديما وحديثا إلى تفنيد هذا التأويل الشكلي، حيث لقي هذا المذهبُ هـجومـا وتسخيفًا شديدين من عبد الله بن مسلم بن قتيبة (ت rVT هـ ) عندما قال: "هذا من أعجب ما حمل عليه كتاب الله، ونحن نعوذ بالله من أن نتعسف هذا التعسف ، ونجيز على الله الزيادة والنقص في الكلام لر أس آية، فأما أن يكون الله وعد جنتين فيجعلهما واحدة من أجل رؤوس الآي، فمعاذ الله ـ وكيف يكون هـذا، وهو يصفهما

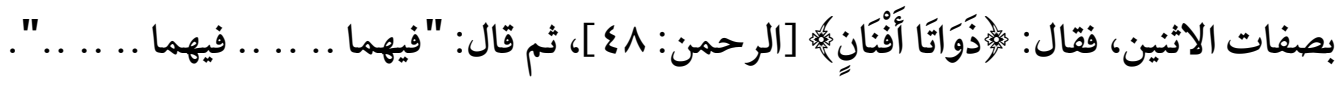
ولو أن قائلا قال في خزنة النار إنهم عشرون وإنما جعلهم تسعة عشر لرأس الآية ، كما قال

$$
\text { نحن بنو أم البنين الأربعة }
$$

وإنما هـم خمسة، فجعلهم كالقافية أربعة ، ما كان في هذا القول إلا كالفر اء"(؟) ، أما تثنيتها فالثابت أن هذا لا يُقصد به مراعاة الجرس الموسيقي في الفواصل لأنها وردت

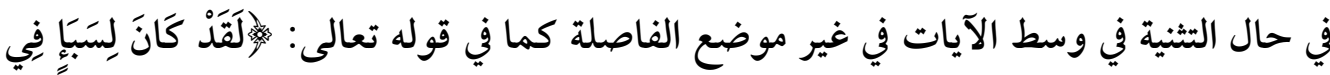

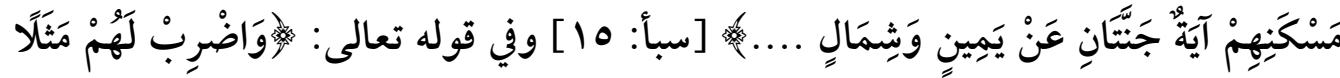

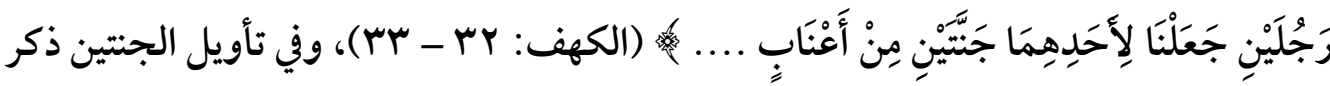

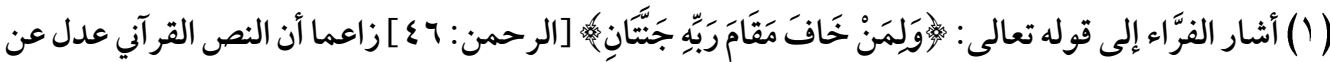
إفراد الجنة إلى تثنيتها مر اعاة للفاصلة التي تنتهي بالألف والنون، وقد لقي تأويل الفراء رضى من جانب عدد قليل

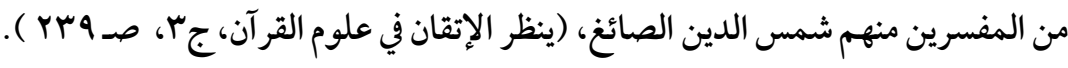

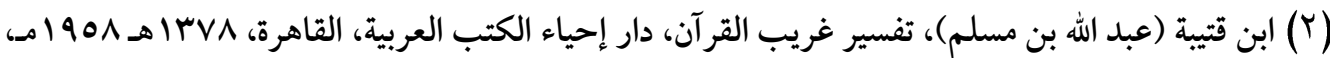




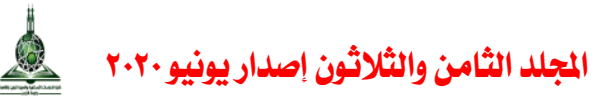

المفسرون أنهما جنة الدنياوجنة الآخرة (')، أو أن رؤية المؤمن لموقعه من النار قبل دخوله الجنة هو جنة ووقاء ووِجَاء في حد ذاته، كما أن رؤية الثقي لموقعه من الجنة قبل دخول النار هو في

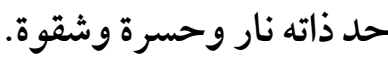

ولم تترك الدراسات القر آنية موضعا من مواضع العدول عن الأصل في باب الفاصلة إلا

واستجلوا ما خفي من مضامينه المعنوية وأسراره الفنية(؟)، وهو ما لم يقع في دراسات روبرت لوث، حيث ظلَّت المتوازيات الإيقاعية تقف عند الشكل المجرَّد ولا تتجاوزه إلى التأويل الموضوعي .. وقد انعكس هذا الاختلاف المنهجي على البنية الاصطلاحية لقضية التوازي/التناظر/ المثاني في القرآن والتوراة، فقي حين دفعت البنية التوازنية دارسي النص التوراتي إلى وصف هذا النص بـ (الشعر العبري المقدس)(ז) رفض دارسو القر آن الكريم تشبيه القرآن بالشعر وعدوا هذا التشبيه من قبيل الانتقاص من قدسية النص القرآني، وما وقع ذلك إلا

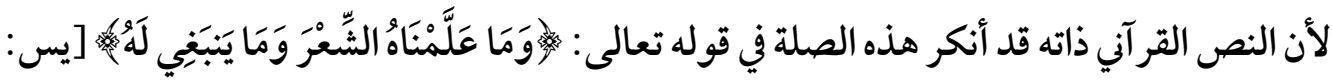
974]، ولأجل هذا السبب نفسه رفضت الدراسات القرآية أن تطلق على أنماط التوازي الصوتي والإيقاعي في النص الكريم تسمية السجع، وذلك لأن السجع قد يتيح لمن يستخدمه تطويع

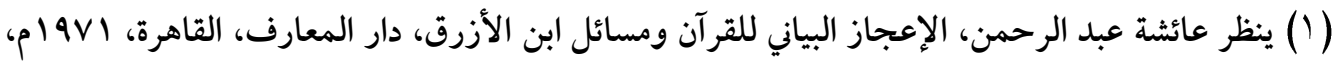
صמم

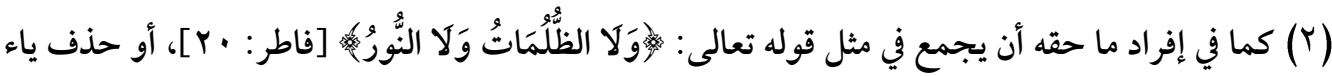

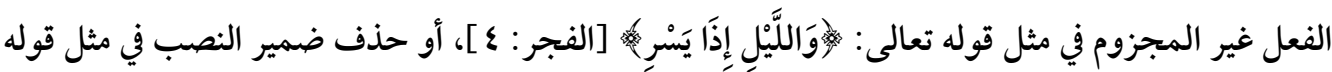

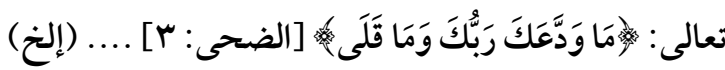

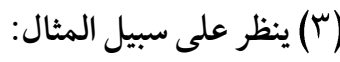

- Newman, L, I, Parallelism in Amos, studies in Hibical Parallelism, Part 1, 1918.

- James Fox , Roman Jakobson and the Comparative Study of Parallelism, To Honor Roman Jakobson s seventieth birthday. Mouton, 1970. 


\section{فرائد البنية التناظرية في النص القرآني (دراسة اسلوبية احصائية مقارنة)}

المعنى للوفاء بمقتضيات التوازي الصوتي والإيقاعي، ومن أجل ذلك استبدل هؤلاء الدارسون مصطلح الفاصلة بمصطلح السجع، ليكون السجع علما على أشكال التوازي الصوتي / الإيقاعي في الثثر البشري، وتكون الفاصلة علما على هذه الأشكال في النص القر آني .. وقد كان السجع هو الفن البلاغي الأوحد الذي آثر دارسو النص القرآني استبداله، حيث

لم يقع هذا الاستبدال في سائر فنون البلاغة كالاستعارة والتشبيه والمجانسة والطباق ... (إلخ)، وما ذلك إلا لأن السجع - كما يرى البلاغيون العرب الذين صكوا مصطلح الفاصلة - يحقق التوازي الصوتي/ الإيقاعي الذي يقف عند حدود الوفاء بالشكل ولو كان ذلك على حساب المضمون ..

ولعل هذا الاختلاف الهائل في السياق المعرفي والثقافي والحضاري بين الدرسين التوراتي والقرآني هو ما يقف وراء تفسير الربط الثاذ من جانب روبرت لوث بين دراسات التوازي في النص التوراتي وبين مصطلح العروض (Prosody) الذي هو مصطلح يتعلَّق بفن الشعر .. وقد أشار روبرت لوث إلى تعلد صور التوازي التركيبي على وجوه تربو على الحصر، فقال: "إن التنوع في أشكال هذا التوازي التركيبي كبير جدا، ودرجات التماثل لانهائية تقريبا"(')، ولكن دراسة لوث لم تتسع لرصد تجليات هذا التنوع، وهو ما لم يقع في الدراسات العربية، حيث تميزت الدراسات القرآنية لمفاهيم التوازي التركيبي بوجه خاص والتوازي بوجه عام عن دراسات روبرت لوث باتساع مفاهيم التناظر الأسلوبي لتشمل تلك التي لا تنحصر في سفر بعينه أو إصحاح بذاته أو فقرة بمفردها - كما هي الحال في دراسة لوث - بل تجاوزت ذلك إلى تناول ما تيسر لها من الأشكال اللانهائية للتوازي في مجمل النص المقدس .. مثل: (أ) : الآيات المكررة بوجوه مختلفة في سياقات مختلفة، كما هو الثأن في قوله تعالى في مطلع

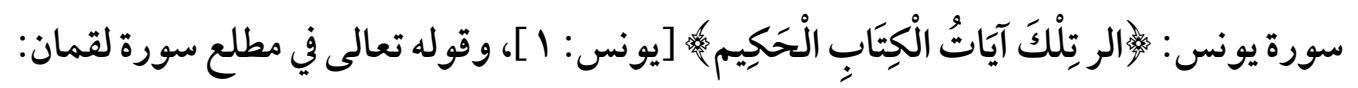

(1) Robert Lowth ‘Lecture on the sacred poetry of Hebrews ‘p164. 


\section{المجلد الثامن والثاثثون إصدار يونيو.r.r.}

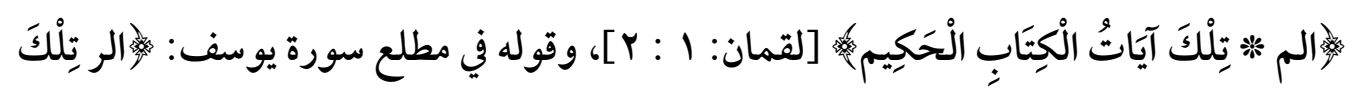

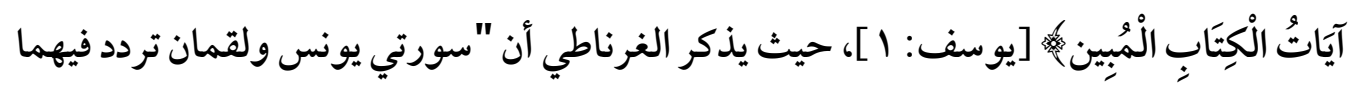

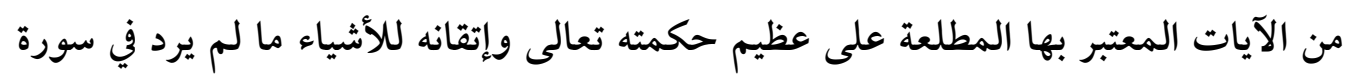
يوسف..."(')، وقد تنوولت هذه الظواهر في عددٍ هائل من المصنفات منها على سبيل المثال أسرار التكرار للكرماني وكثف المعاني في متشابه المعاني لابن جماعة وملاك التأويل للغرناطي..

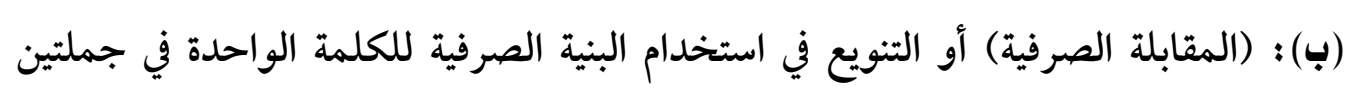
متاليتين كما في الأمثلة التالية:

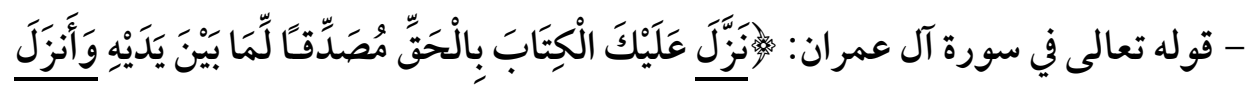

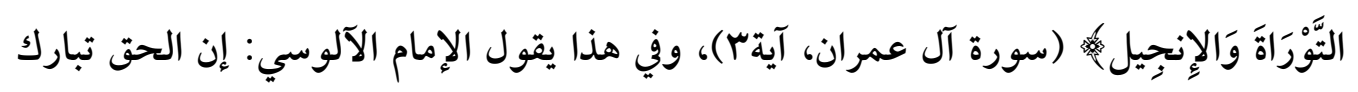

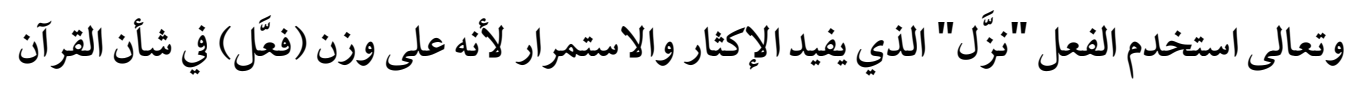

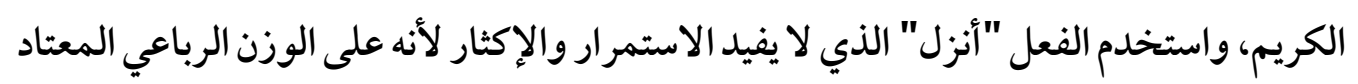

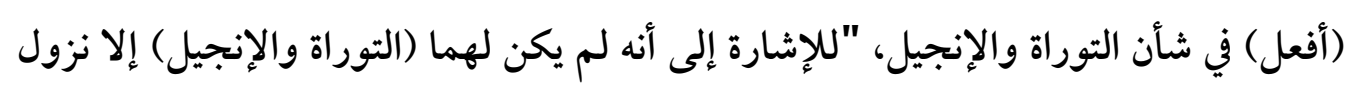

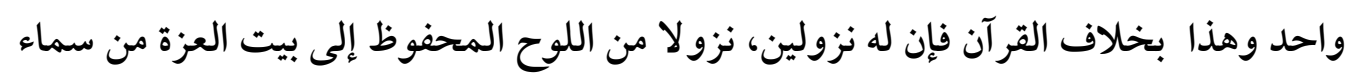

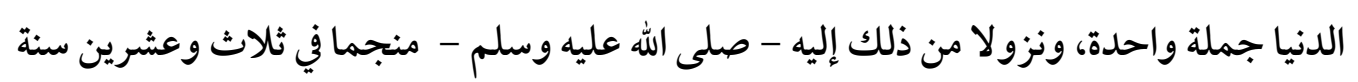

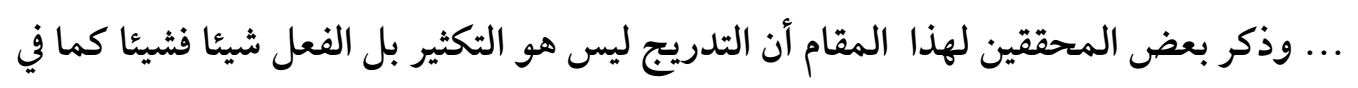

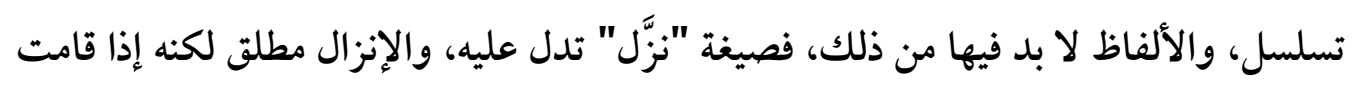

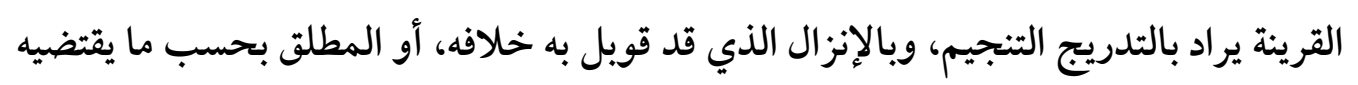

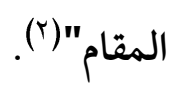

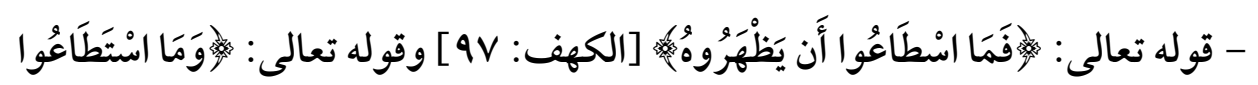

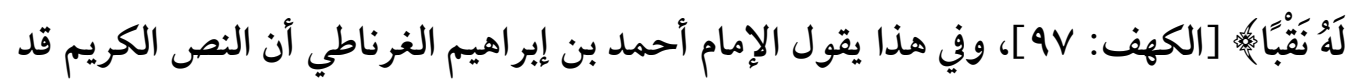

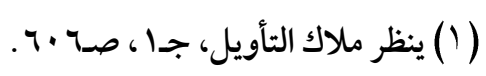

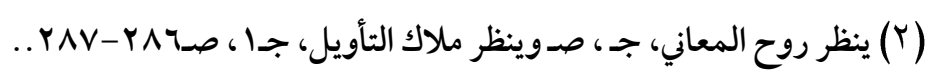


استخدم الفعل "اسطاع" مخففا للتعبير عن الأسهل، وهو الصعود على السد، في حين استخدم الفعل التام المستوفي "استطاع" للتعبير عن الصعب، وهو نقب السد واختراقه (1)

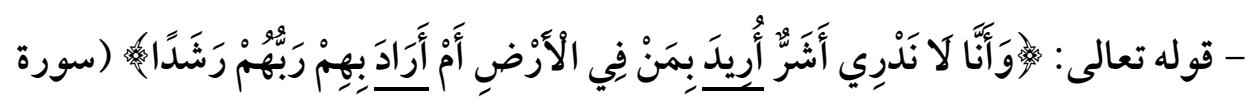
الجن، الآية · ( )، حيث آثر النص القر آني بناء الفعل للمعلوم وهو الإرادة الإلهية حين كان القصد إرادة الرشد، في حين آثر بناء الفعل للمجهول حين كان القصد إرادة الشر (r). (ج) : (المقابلة التركيبية) أو تضاد البنية التركيبية بين عبارتين غير متجاورتين، كما هي الحال بين

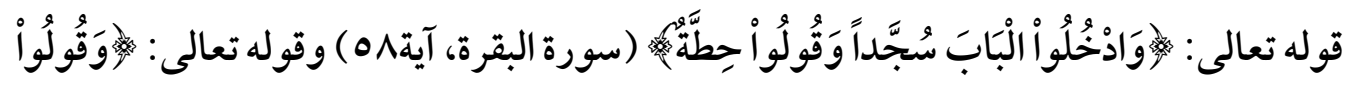

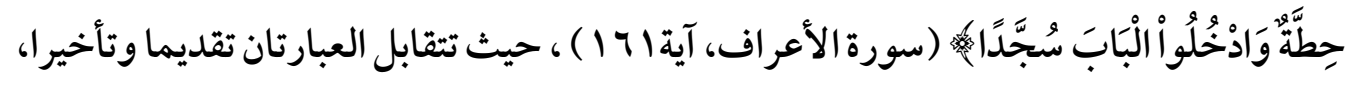
وتتعدد تأويلات المفسرين والبلاغيين لهذا التناظر التركيبي كالذي ذهب إليه الغرناطي من أن غاية المغايرة إثبات أن الأمر الإلهي لبني إسر ائيل بأن يدعوا ربهم سبحانه وتعالى بأن يحط عنهم أوزارهم كان متعلقا بحال سجودهم وجاءت المغايرة لتثبت هذا التعلق الذي قد يخفى بسبب وجود أداة العطف بين العبارتين والتي قد توهم التعاقب وعدم التعلق (r).

$$
\begin{aligned}
& \text { ( (l) ينظر مِلاك التأويل، جr، ص.V9. }
\end{aligned}
$$

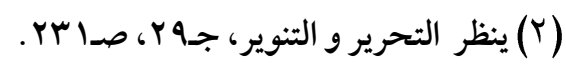

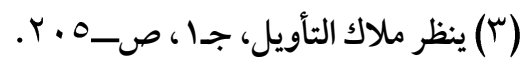

- Isaiah: a New Translation with a Preliminary Dissertation, and Notes, Critical, Philosophical, and Explanatory, Boston: William Hillard, 14 Water Street, Cambridge: James Munroe and Company, 10th English Edition, 1834.

- Lecture on the sacred poetry of Hebrews, London, printed for Thomas Tegg \& Son, Cheapside, Tegg, Wise \& Tegg, Dublin, Griffin \& Co. Glasgow, and James \& Samuel Augustus Tegg, Sydney, Australia, The Third Edition.

- Zellig S. Harris, (Formal linguistics series) Papers in Structural and Transformational Linguistics, Springer (a global publisher), Dec 1, 2013.

- http://www.a7bash.com/book.php?action=showbook\&id=60.

$$
\text { - مواقع إليكترونية: - n }
$$




\section{الخاتمة}

\section{وفيها أهم نتائج الدراسة:}

- َتََََّّ التوازي التقابلي (التضادي) في دراسة روبرت لوث للعهد القديم بين تضادِ في الكلمة، وتضادٍ في العبارة على ما يتسق مع تفرقة المصطلح البلاغي العربي بين الطباق والمقابلة، ولكن "لوث" قد أضاف تنوعا جديدا لطباق الكلمات، هو المطابقة بين مفرد ومفرد، والمطابقة بين جمع وجمع .. كما أضاف لوث المقابلة بين التضاد البسيط والتضاد المركب حيث يتسق التضاد المركب مع القسم الثاني من أقسام المقابلة القرآنية التي تتعدد أطر افها عند الزركشي الذي قصد به ورود الطرفين الثانين للطباقين في العبارة وفق ترتيب الطرفين

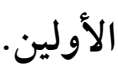

- أفصحت الدراسة المقارنة بين معدلات التكرار في الألفاظ المتقابلة في النص القرآني ونظيرتها في النص التوراتي عن تفرد النص القر آني باتساق ملحوظ في أعداد الألفاظ المتقابلة

$$
\text { على وجه غير مكرور. }
$$

- يدل الضبط الممنهج للمتواليات العددية في النسق التكراري لكلمات القرآن الكريم على حقيقة واضحة مؤداها أن كلام الله الذي نزل على محمد - صلى الله عليه وسلم - منجما عبر ثلاثة وعشرين عاما هو قول واحد لإله واحد وما هو بقول مخلوق ولو كان كذلك لما جاء مسبو كا على هذه الحال البليغة في الضبط والحصر، وفي هذا السياق تتبدي أهمية أمية النبي محمد - صلى الله عليه وسلم - ، لأنه لو كان قارئا كاتبا لظن المرجفون أنه هو من عدَّد هذه المقابلات وحصرها، وإن افترضنا - جدلا - هذا الاحتمال فلماذالم يشر إليه وقد بذل فيه هذا الجهد المضني؟ 
- على الرغم مما أحيطت به المناهج الإحصائية الرياضية من سوء الظن من جانب كثير من الدارسين فيما يخص ما يمكن أن تحققه من نتائج - حيث يجمع عدد كبير من الدارسين على أن "النتائج المادية لهذه المناهج لم تقدم تفسير امناسبا في مجال الدراسات الأدبية، حيث إن لهذه النتائج طاقة توضيحية محدودة، فتقابل هذه الموضوعات الكبيرة ضآلة في أهمية نتائجها"، وقد أفصحت التتائج التي ترتبت على دراسة الإبداع الأدبي وفق هذه المناهج الرياضية عن خلل كبير تحقق من جرَّاء إخضاع إبداع يصدر من الشعور ويعبر عن الذوق الذي يتأبى على المادة ويستعصي على المنطق العقلي إلى مقاييس مادية ومعايير ذهنية، ولكننا - وعلى الرغم من ملامح القصور الملحوظة في هذه المناهج الإحصائية فيما يخص الدراسات الأدبية - نجد هذه المناهج قد حققت نجاحا كبير افي تطبيقها على النص القرآني، وذلك لأن هـذاك النص الإلهي قد منح هذه المناهج الإحصائية الرياضية نتائج هائلة الخطر تتسم بقدر غير مسبوق من المصداقية والحسم. - انفرد النص القرآني بتحقق التناظر على مستوى السورة، حيث بنيت السورة القر آنية على تناسب مُطَّرد تحقق عبر التقابل أو الترادف بين أول السورة وآخرها، وهو ما لم يتحقق في

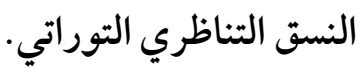
- أفصحت المقارنة بين النص القرآني والنص التوراتي في شأن البنية التناظرية على مستوى العبارة عن تفرد النص القر آني في محورين: أولا: مبدأ العدول عن المضادة المعيارية/ القياسية. ثانيا: مبدأ "التعليل" أو (علاقة الشكل بالمضمون). - م لم تتحقق الرؤية التقعيدية المعيارية للمقابلة بوصفها نقيضا للمساواة والترادف في الموروث البلاغي العربي بهذه الصورة المحكمة إلا على يدي السكاكي وتلامذته من 


\section{المجلد الثامن والثلاثثن إصدار يونيو.r.r.}

البلاغيين المتأخرين، أما البلاغيون المتقدمون ومن تنكب معايير السكاكي من البلاغيين

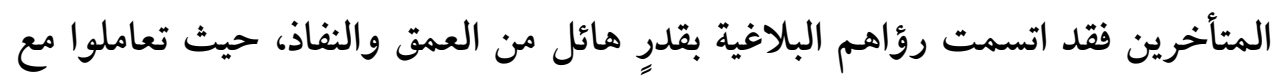

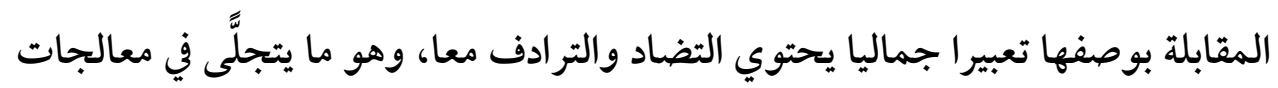
قدامة بن جعفر وأبي هلال العسكري وابن رشيق القيرواني وحازم القرطاجني والزركشي

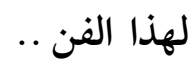
- قسم لوث التوازي الترادفي في التوراة إلى خمسة أقسمة، التسم الأول يتكرر فيه المعنى دون اللفظ والقسم الثاني يتكرر فيه المعنى واللفظ معا، والقسم الثالث تكرر فيه العبارة الثانية جزءا من العبارة الأولى لفظا ومعنى أو معنى فقط، والقسم الرابع تترادف فيه ثلاث عبارات بطريقة خاصة، حيث يترادف السطر الثاني مع السطر الأول، ثم يشير السطر الثالث إلى كلا السطرين السابقين، وهو الوجه الذي أطلق عليه "لوث" تسمية (المتوازيات الثلاثية)،

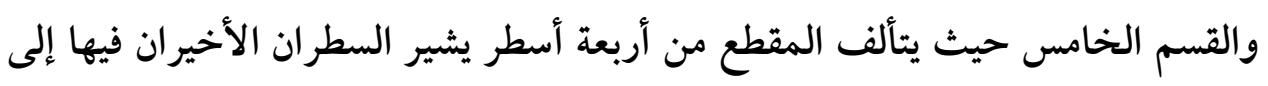
السطرين الأولين (بالتناوب)، حيث يترادف السطر الثالث مع السطر الأول ويترادف السطر الرابع مع السطر الثاني.. - اكتفى لوث بالإشارة إلى اختلاف الأشكال المتر ادفة دون أن يقدم تعليلا معنويا لها على غرار الدراسات القرآنية، كما لم تطرح أسفار التوراة تصورا ذا دلالة في شأن التناظر الترادفي على مستوى النص فظلت الدراسات التوراتية منحصرة في إطار الكلمة والجملة، في حين طرح النص القر آني تصورات إحصائية ذات دلالات هائلة في إطار التناظر الترادفي في مجمل

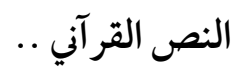
- تحققت في النص القرآي تناظرية عددية متكررة في كثير من ألفاظه المتر ادفة والمتقابلة في آنٍ، وهو ما شكل خواص أسلوبية Stylistic Markers لا تخضع في تفسيرها لنظرية 
المصادفة، ولكنها عبرت عن نهج مقصود في النص الكريم يختلف به هذا النص عما دونه من النصوص المقدسة، وهو ما أثبتهه الدراسة من خلال الموازنة بين نواتج الإحصاء العددي للألفاظ المتر ادفة في القر آن والتوراة ..

- اتسعت ظواهر التناظر والتوازي في النص القرآني على وجه لم يتكرر فيما دونه من النصوص المقدسة وخصوصا العهد القديم، حيث انبنت السورة القرآية على ثناسب نمطي بين أول السورة وآخرها على وجه مطرد ... - تكررت في القرآن الكريم ظواهر التوازي التركيبي التي رصدها روبرت لوث في التوراة .. - لم يخص روبرت لوث التوازي الإيقاعي في التوراة بحديث خاص، لكنه جعل التوازي الإيقاعي أحد تجليات التوازي التركيبي، وهو ما لم يقع في الدراسات القر آنية التي فصلت بين ظواهر التناظر التركيبي وظواهر التناظر الإيقاعي التي أفردت لهادرسا مستقلا كان من تجلياته علم الفاصلة القر آنية، وقد اتسق هذا الاختلاف بين الدراسات القرآية والدراسات التور اتية مع الاختلافات الجذرية في السياق الثقافي والحضاري لكل من النصين المطروحين للدراسة..

- في دراسته ظواهر التوازي الإيقاعي في النص التوراتي لم يشفع لوث هذه الظواهر بأية مسوغات فنية تتعلق ببنية المعنى، وهو ما لم يقع في الدراسات القر آنية التي علقت القيمة الموسيقية المتحققة في مقاطع الآيات بالقيمة المعنوية التي تحملها وتعبر عنها . - يعيد استواء الكتب المقدسة في صفة التوازي طرح نظرية وحدة الأصل الديني الذي صدرت منه التجليات الدينية المختلفة، حيث تتفق كل المصادر الدينية المختلفة زمنيا ومكانيا في عدد من الظواهر تأتي ظاهرة التوازي على رأسها.. - يؤكد استو اء كل الكتب المقدسة في استخدام ملمح التوازي بوصفه ملمحا ملتصقا بالطبقة 
الدينية على تفرد النص القر آني في هذا المنحى المشترك بين كل النصوص الدينية .. - أفصحت الدراسات الإحصائية لمفردات التوراة عن عدد من الدلالات ذات الأهمية القصوى في سبيل إدراك حدود الاتجاه الروحي في النص التوراتي، ففي حين وردت مفردة الدنيا خلا النص - تماما - من ذكر مفردة الآخرة أو مترادفاتها مثل القيامة أو البعث أو النشور أو يوم الحساب، وفي شأن ثنائية الطهر والإخلاص طوفت مفاهيم مفردات الطهارة حول دلالات النظافة المادية (نظافة الجسد) دون أن تتطرق إلا في نذر يسير إلى التعبير عن دلالات الطهارة المعنوية (طهارة النفس)، وبالمثل تضاءلت المدلولات الروحية لمفردات الإخلاص، بل لم ترد لفظة (الإخلاص) في أي موضع من العهد القديم، ، كما لم ترد كلمة (يخلص) ولا الفعل (أخلص) ولا الاسم (مخلص) ووردت لفظة (خالص) وحسب 19 مرة منها س ا مرة مضافة إلى كلمة الذهب في التعبير الإضافي "الذهب الخالص"، وهو الأمر الذي يفتح بابا وسيعا لدراسة دلالات هذا الارتباط الشرطي بين مفردات بعينها في النص التوراتي من خلال ما يطلق عليه الأسلوبيون الإحصائيون تسمية (المصاحبة اللفظية) .. "Connotation" 


\section{تُبتث المصادروالمراجع}

$$
\begin{aligned}
& \text { أولا: المصادر: } \\
& \text { - القرآن الكريم. } \\
& \text { - }
\end{aligned}
$$

(الرواية الأرثوذكسية) عن طبعة الكتاب المقدس التي أصدرتها الكرازة المرقسية الأرثوذكسية تحت إشراف دار الكتاب المقدس بالقاهرة، الطبعة الرابعة، سنةب | ·Yم،

$$
\text { وضمت تسعة وثلاثين سفرا. }
$$

(الرواية الكاثوليكية) وتزيد عن الرواية الأرثوذكسية سبعة أسفار أخرى ليبلغ عدد أسفارها

$$
\text { ستة وأربعين سفرا. }
$$

$$
\text { ثانيا: المراجع: }
$$

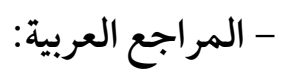

- الألوسي (أبو الفضل شهاب الدين السيد محمود البغدادي)، روح المعاني في تفسير القرآن العظيم والسبع المثاني، تحقيق وتخريج د. السيد محمد السيد وسيد إبراهيم عمران، دار

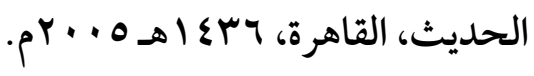

- ابن الأثير، المثل السائر في أدب الكاتب والشاعر، تحقيق د. أحمد الحوفي ود. بدوي طبانة،

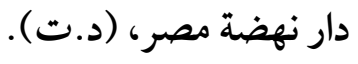

- الأزهر الزناد، نسيج النص "بحث فيما يكون به الملفوظ نصا"، المركز الثقافي العربي، الدار البيضاء، الطبعة الأولى، ب991 مـ، صدץ 1، وينظر محمد مفتاح، المفاهيم معالم، المركز الثقافي العربي، الدار البيضاء، الطبعة الأولى، 1999. - البقاعي (برهان الدين أبو الحسن إبراهيم بن عمر المتوفى 1110هـ )، نظم الدرر في تناسب الآيات والسور، خرَّج آياته وأحاديثه ووضع حواشيه عبد الرزاق غالب المهدي، دار الكتب

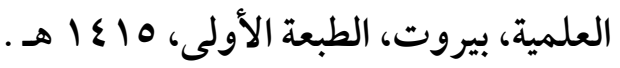


- البيضاوي (القاضي ناصر الدين أبو سعيد عبد الله بن عمر بن محمد الشيرازي (ت ال ولهـ)، أنوار التنزيل وأسرار التأويل، تحقيق أ.د حمزة النشرتي والشيخ عبد الحفيظ فرغلي

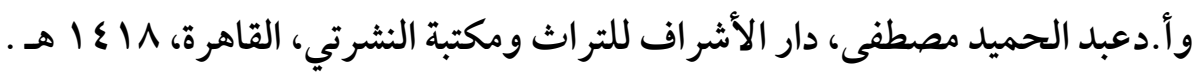
- الجاحظ (أبو عثمان عمرو بن بحر المتوفى Y00 هـ )، البيان والتبين، تحقيق وشرح عبد

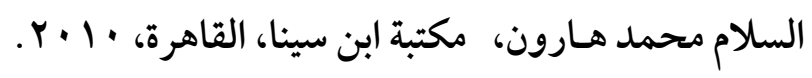

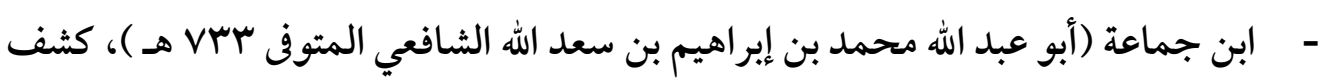
المعاني في متشابه المثاني، حققه وقدم له وعلق عليه د. محمد محمد داود، دار المنار للنشر

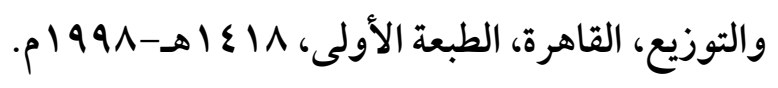
- حازم القرطاجني (الحسن)، منهاج البلغاء وسراج الأدباء، تقديم وتحقيق محمد الحبيب بن الخوجة، دار الكتب الشرقية، تونس، الطبعة الأولى، 979 ام. - حسين نصار (دكتور)، التكرار، مكتبة الخانجي، القاهرة، الطبعة الأولى، سب؟اهـ pr. r

- حلمي محمد شرف (دكتور)، المجلس الأعلى للشئون الإسلامية، القاهرة، ب1919 ام - الحلي (صفي الدين)، شرح الكافية البديعية في علوم البلاغة ومحاس البديع، تحقيق د. نسيب نشاوي، دمشق، · مو ام. - الزركشي (الإمام بدر الدين محمد بن عبد الله بن بهادر)، البرهان في علوم القرآن، تحقيق محمد أبو الفضل إبر اهيم، مكتبة عيسى البابي الحلبي، القاهرة، الطبعة الأولى، ه 9 أم. - الزمخشري (أبو القاسم جار الله محمود بن عمر الخوارزمي)، الكثاف عن حقائق التنزيل وعيون الأقاويل في وجوه التأويل، شرحه وضبط مراجعه يوسف الحمادي، مكتبة مصر، . $r \cdots$ - سعد عبد العزيز مصلوح (دكتور)، الأسلوب دراسة لغوية إحصائية، عالم الكتب، القاهرة،

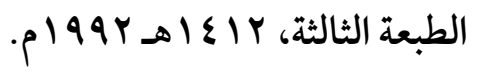




$$
\text { - السيوطي (جلال الدين المتوفى } 91 \text { هـ ): }
$$

تناست الدرر في نظم الآيات والسور، تحقيق عبد القادر أحمد عطا، دار الكتب العلمية،

$$
\text { بيروت، الطبعة الأولى، } 7 \text { · ع } 1 \text { هـ . }
$$

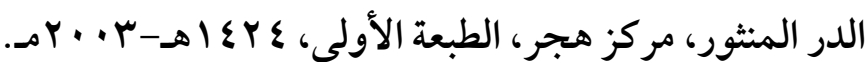

شرح عقود الجمان في علم المعاني والبيان، مطبعة ومكتبة مصطفى البابي الحلبي،

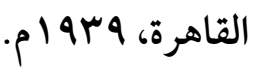

علم المناسبات في السور والآيات، تحقيق د. محمد بن عمر بن سالم بارمول، المكتبة

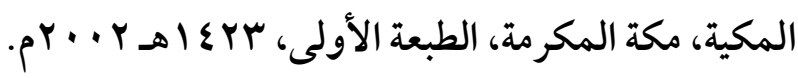

مراصد المطالع في تناسب المقاطع والمطالع، تحقيق د. محمد بن عمر بن سالم بارمول، المكتبة المكية، مكة المكرمة، الطبعة الأولى، سY \& أهـ Y . . ب م. الإتقان في علوم القرآن، تحقيق طه عبد الرؤوف سعد، المكتبة التوفيقية، القاهرة،

$$
\text { (د.ت) }
$$

- الثيخ (دكتور عبد الواحد)، البديع والتوازي، مكتبة الإشعاع، الإسكندرية، الطبعة الأولى،

$$
\begin{aligned}
& \text {. 1999ـ18 19 } \\
& \text { - صلاح فضل (دكتور): }
\end{aligned}
$$

باغة الخطاب وعلم النص، المجلس الوطني للثقافة والفنون والآداب، الكويت،

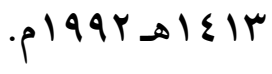

علم الأسلوب مبادئه وإجراءاته، دار الثروق، القاهرة، الطبعة الأولى، 19 ـ اهـ

$$
\cdot p 1991
$$

النظرية البنائية في النقد الأدبي، الطبعة الثانية، القاهرة، مكتبة الأنجلو المصرية، • 191 ام. - صموئيل مشرقي (القس ورئيس المجمع العام لكنائس الله الخمسينية)، مصادر الكتاب المقدس بحث في أصول الكتاب وبيان حقيقة مصادره، الناشر : الكنيسة المر كزية بجزيرة 


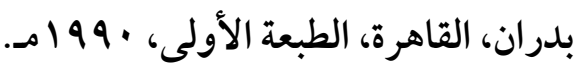
- الطبري (أبو جعفر محمد بن جرير)، جامع البيان عن تأويل آي القرآن، حققه وخرَّج أحاديثه محمد محمود شاكر، دار المعارف، القاهرة، (د.ت). - عائشة عبد الرحمن، الإعجاز البياني للقرآن ومسائل ابن الأزرق، دار المعارف، القاهرة، (9VI - ابن عاشور (محمد الطاهر بن محمد بن محمد الطاهر التونسي) ، التحرير والتنوير (تحرير المعنى السديد وتنوير العقل الجديد من تفسير الكتاب المجيد)، الدار التونسية للنشر، .p $919 \varepsilon$ - عبد الفتاح لاشين (دكتور)، بلاغة القرآن في آثار القاضي عبد الجبار وأثره في الدراسات البلاغية، دار القر آن، القاهرة، I9V^ ام.

$$
\text { - - مبد الرزاق نوفل (دكتور): }
$$

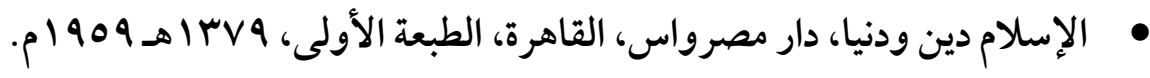

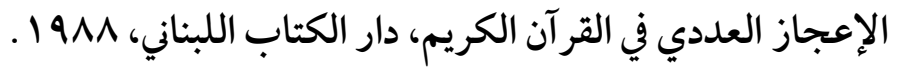

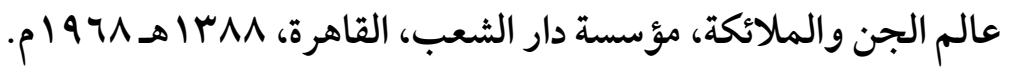
- عز الدين المناصرة (دكتور)، علم الشعريات (قراءة مونتاجية في أدبية الأدب)، الطبعة

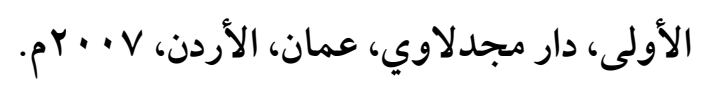

- العسكري (أبوهلال)، الصناعتين في الكتابة والشعر، تحقيق علي محمد البجاوي ومحمد

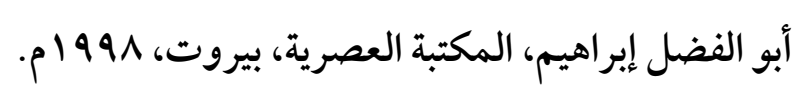

- عفت الشرقاوي (دكتور)، الفكر الديني في مواجهة العصر، دار الحقوق للطبع والنشر

$$
\text { والتوزيع، القاهرة، ع191ام. }
$$

- العلوي (يحي بن حمزة بن علي بن إبراهيم العلوي اليمني المتوفىه ع هـ )، الطراز

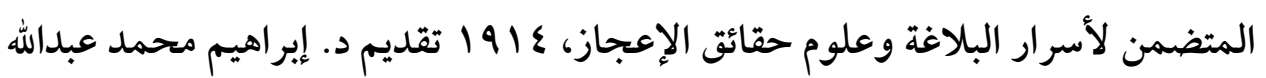


الخولي، الهيئة العامة لقصور الثقافة، القاهرة، 9 ، . r م، نسخة مصورة من مطبعة دار الكتب

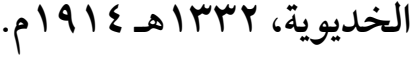

$$
\begin{aligned}
& \text { - الغرناطي (أحمد بن ءابر اهيم بن الزبير الثقفي المتوفى } 1 \text { • V هـ ): }
\end{aligned}
$$

البرهان في ترتيب سور القر آن، بتحقيق محمد شعباني، الناشر وزارة الأوقاف والشئون - فاضل صالح السامرائي (دكتور)، بلاغة الكلمة في التعبير القرآني، مكتبة العاتك، القاهرة،

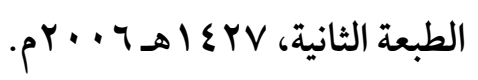
- فتح الله سليمان، الأسلوبية مدخل نظري ودراسة تطبيقية، الدار الفنية للنشر والتوزيع،

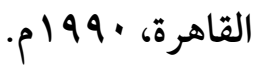
- الفخر الرازي (الإمام فخر الدين محمد بن ضياء الدين عمر بن الحسين المتوفى · ج هـ )، : تفسير الفخر الرازي المسمى التفسير الكبير ومفاتيح الغيب، تقديم خليل الميس، دار

$$
\text { الفكر، بيروت، الطبعة الأولى، } 1 \text { ، ع أهـ 1919 ام. }
$$

نهاية الإيجاز في دراية الإعجاز، تحقيق ودراسة نصر الدين حاجي مفتي أوغلو، دار صادر،

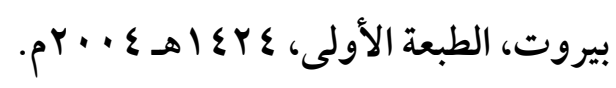

- ابن قتيبة (عبد الله بن مسلم) ، تفسير غريب القرآن ، دار إحياء الكتب العربية، القاهرة،

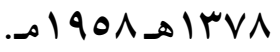
- القرطبي (أبي عبد الله محمد بن أحمد الأنصاري)، دار الريان للتراث (طبعة خاصة بتصريح من دار الشعب)، القاهرة، (د.ت) . الدر المنثور - الكر ماني (يحي بن حمزة)، البرهان في توجيه متشابه القر آن لما فيه من الحجة و البيان (أسرار التكرار في القرآن)، دراسة وتحقيق عبد القادر أحمد عطا، مرجعة وتعليق أحمد عبد التواب 
عوض، دار الفضيلة، القاهرة، 9VV

- كمال عبد العزيز إبراهيم (دكتور)، أسلوب المقابلة في القرآن الكريم دراسة فنية بلاغية

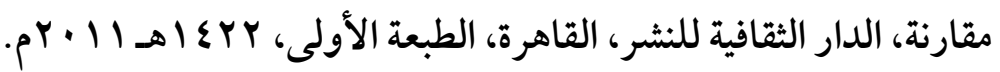
- محمد عبد المطلب(دكتور)، البلاغة العربية قراءة أخرى، طبعة الشر كة المصرية العالمية

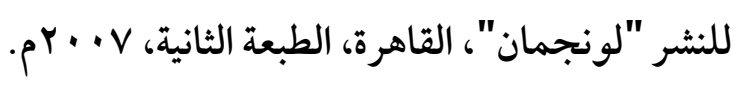
- النويري، نهاية الأرب في فنون الأدب، تحقيق مفيد قميحة، دار الكتب العلمية، بيروت،

$$
\text { - - المر اجع المترجمة: }
$$

- برند شبلنر، علم اللغة والدراسات الأدبية "دراسة الأسلوب، البلاغة، علم اللغة النصي"، ترجمه وقدم له وعلق عليه د. محمود جاد الرب، الدار الفنية للنشر والتوزيع. - جان بياجيه، البنيوية، ترجمة: عارف منيمنة وبشير أوبري، الطبعة الثالثة، بيروت، باريس،

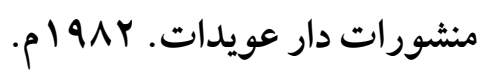

- ج. كونتنو، الحضارة الفينيقية، ترجمة محمد عبد الهادي شعيرة، مر اجعة د. طه حسين،

$$
\text { الهيئة المصرية العامة للكتاب، } 991 \text { ام. }
$$

- روبرت دي بوجراند، النص والخطاب والإجراء، ترجمة د. تمام حسان، عالم الكتب،

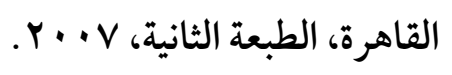

- زرادشت، ترانيم زرادشت من كتاب الأفستا المقدس، ترجمة وتقديم فيليب عطية (وهي الترجمة العربية التي نقلها صاحبها عن الصياغة الإنجليزية كما أعدها جاك دوشن جيلمان والتي نشرت تحت عنوان Hymns of Zarathustra، الهيئة المصرية العامة للكتاب، سنة س99 (19 مـ. - فولفجانج هاينه وديتر فيهفيجر، مدخل إلى علم اللغة النصي، ترجمة فالح شبيب العجمي، جامعة الملك سعود، الرياض، 1999 مـ. 
- حاجي خليفة، كشف الظنون عن أسامي الكتب والفنون، تحقيق مصطفى بن عبد الله، دار

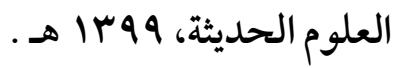
- فلوجل (جوستاف) "نجوم الفرقان في أطراف القرآن،

(Gustavus Flugel, concordantia corani arabicae, edition stereotyba caboli tauchnitil, lipsiae, 1875) - الكفوي (ته؟ - 1 هـ) (أبو البقاء أيوب بن موسى الحسيني)، (الكليات معجم في المصطلحات والفروق اللغوية)، قابله على نسخة خطية وأعاده للطبع ووضع فهارسه عدنان درويش ومحمد المصري، مؤسسة الرسالة، بيروت، الطبعة الثانية، 991 امـ - محمد فؤاد عبد الباقي، المعجم المفهرس لألفاظ القرآن الكريم، دار الحديث، القاهرة،

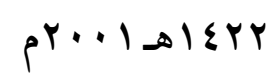

- لسان العرب، تحقيق عبد الله علي الكبير ومحمد أحمد حسب الله وهاشم محمد الشاذلي،

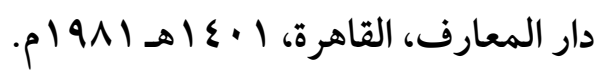
- المعجم العلمي للمعتقدات الدينية، إعداد مجموعة من علماء مقارنة الأديان، تعريب وتحرير سعد الفيشاوي، الهيئة المصرية العامة للكتاب، القاهرة، V · . Pم. - الدوريات: - عبد القادر جبار (دكتور)، التوازي بين لغة القرآن الكريم والكتاب المقدس، مقال منثور

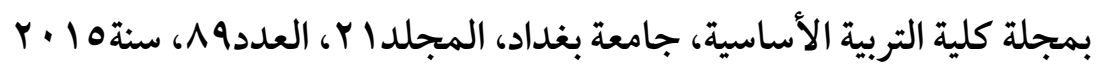
- إنصاف عبد الله الحجايا، التوازي التركيبي الصرفي في القرآن الكريم دراسة في الأساليب اللغوية، رسالة ماجستير مخطوطة، إشراف د. عادل بقاعين، الأردن، جامعة مؤتة، 17 . . . . - سهيلة زتوت، التوازي في القرآن الكريم دراسة في النظم الصوتي والتركيبي الربع الأخير 
أنموذجا، رسالة ماجستير مخطوطة، إشراف د. على زيتونة مسعود، الجزائر، جامعة

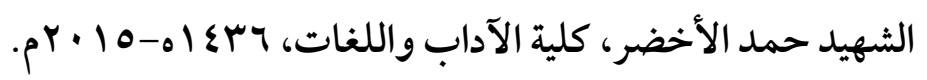

- عبد الله خليف خضير عبيد الحياني، التوازي التركيبي في القرآن الكريم، رسالة ماجستير

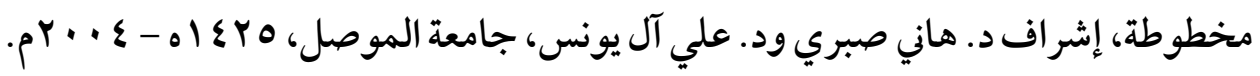

- العربي عبد الله، بلاغة التوازي في السور المدنية، رسالة ماجستير مخطوطة، إشراف د.

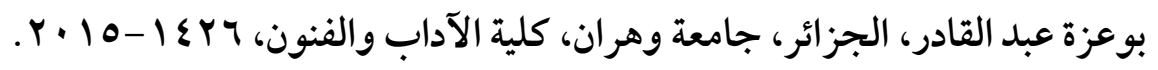
- هاني صبري (دكتور)، توازي الضمائم في النسق القر آني، مقال مشور في مجلة التربية والعلم،

$$
\begin{aligned}
& \text { بغداد، العدد الرابع، ^ • . . . } \\
& \text { - المراجع الأجنبية: }
\end{aligned}
$$

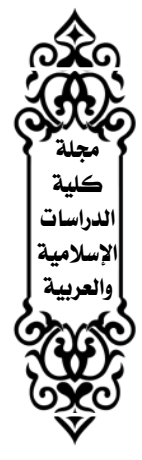

- Donald W. Parry, Poetic Parallelisms in the Book of Mormon, The Neal A. Maxwell Institute for Religious Scholarship, Brigham Young University, Provo, Utah, 2007.

- D.Delas. 'J.Fill 'Linguistique et poétique, langue et language, Larousse, Paris 1973.

- James Fox , Roman Jakobson and the Comparative Study of Parallelism, To Honor Roman Jakobson s seventieth birthday. Mouton, 1970.

- Jean Molino-Joélle, Tamine 'Introduction à l'analyse de la poésie, presses universitaires de France, Paris, 1982.

- J.C.Coquet, Poetique et Linguistique, in Essais de sémiotique poétique, Larousse, Paris, 1972.

- Michael Riffaterre, Essais de stylistique structurale, Flammarion,1971.

- Monier Williams, Sanskrit English Dictionary, Oxford University Press, Entry for Sutra.

- M Winternitz, A History of Indian Literature, Motilal Banarsidass, Reprint 2010.

- Newman, L, I, Parallelism in Amos, studies in Hibical Parallelism, Part 1, 1918.

- Robert Lowth: 